Portland State University

PDXScholar

\title{
Voices of our past: the rank and file movement in social work, 1931-1950
}

Richard William Hunter

Portland State University

Follow this and additional works at: https://pdxscholar.library.pdx.edu/open_access_etds

Part of the Labor History Commons, Social Work Commons, and the United States History Commons Let us know how access to this document benefits you.

\section{Recommended Citation}

Hunter, Richard William, "Voices of our past: the rank and file movement in social work, 1931-1950" (1999). Dissertations and Theses. Paper 1602.

https://doi.org/10.15760/etd.1601

This Dissertation is brought to you for free and open access. It has been accepted for inclusion in Dissertations and Theses by an authorized administrator of PDXScholar. Please contact us if we can make this document more accessible: pdxscholar@pdx.edu. 


\section{DISSERTATION APPROVAL}

The abstract and dissertation of Richard William Hunter for the Doctor of

Philosophy in Social Work and Social Research were presented February 10, 1999, and accepted by the dissertation committee and the doctoral program.

COMMITTEE APPROVALS:
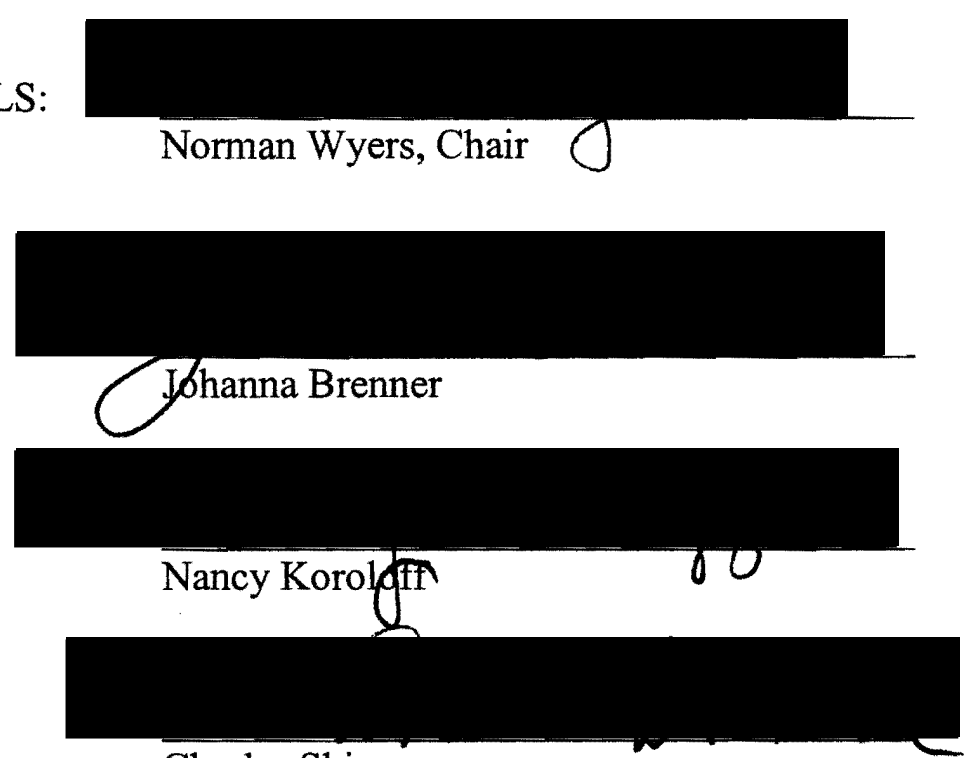

Charles Shireman

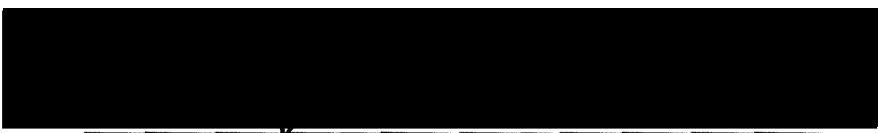

Seymour Aafler

Representative of the Office of Graduate Studies

DOCTORAL PROGRAM APPROVAL:

Joan Shireman, Director

$\mathrm{Ph}$. D. in Social Work and Social Research Program 


\begin{abstract}
An abstract of the dissertation of Richard William Hunter for the Doctor of Philosophy in Social Work and Social Research presented February 10, 1999.
\end{abstract}

Title: Voices of Our Past: The Rank and File Movement in Social Work, 1931-1950

During the period of the late 1920s through the late 1940s, a most remarkable event in the history of American social work emerged: the development of a vital radical trade union organizing effort known as the "rank and file movement." Born within the growing economic crisis of the 1920 s and maturing in the national economic collapse and social upheaval heralded by the Great Depression, the rank and file movement would attract the support and membership of thousands of professional social workers and uncredentialed relief workers in efforts to organize social service workers along the lines of industrial unionism. Within its relatively short life span, the rank and file movement would grow in sufficient number and influence to challenge both the prevailing definitions of social work as a profession - its form and identity and the essence of its function - its practice.

It is the thesis of this study that an understanding of the rank and file movement is central to a modern understanding of our profession. The origin, development and demise of the rank and file movement reflects more than the historical curiosity of a momentary tendency in the evolution of a profession; rather, it reveals the enduring legacy of individuals, organizations and collective intellectual 
discourse in common struggle for the possibilities of a more just and democratic social order. And, perhaps unlike any other profession, the domain of social work is historically one uniquely born of this struggle, encompassing the self-imposed imperatives and paradoxes of morality, socially purposive service and scientific rationality.

Consequently, this study seeks to inform the terms of this enduring legacy within the dynamic world of social work. It does so by: 1) locating the history of the rank and file movement within the context of an evolving profession; 2) analyzing this specific history of a profession within the context of broader social and political forces that defined both the limits and potentials of that evolution; and 3) assessing the implications of this history for social work in terms of its past, present and future. 
VOICES OF OUR PAST:

THE RANK AND FILE MOVEMENT IN SOCIAL WORK, 1931-1950

by

RICHARD WILLIAM HUNTER

A dissertation submitted in partial fulfillment of the requirements for the degree of

DOCTOR OF PHILOSOPHY

in

SOCIAL WORK AND SOCIAL RESEARCH

Portland State University

1999 


\section{ACKNOWLEDGMENTS}

\section{For Bronislaus "Comrade Kilroy" Zukas}

Many individuals have contributed over the years to the final production of this manuscript. First, my thanks go out to the numerous librarians and archivists who graciously provided me access to needed materials at the University of Minnesota, the University of Washington, the University of California - Berkeley, Smith College, the American Institute for Marxist Studies, and the Communist Party, U.S.A. In particular, I owe debts of gratitude to Dr. David Klassen at the University of Minnesota's Social Welfare History Archives, and Herbert Aptheker of the American Institute for Marxist Studies. David, for his hospitality and helpful suggestions regarding the location of documents critical to this study; and Dr. Aptheker for his willingness to share both his counsel in the early years of this work and his good name in recommending me to rank and file activists.

My thanks also go out to the members of my dissertation committee. Drs. Nancy Koroloff, Johanna Brenner, Charles Shireman and Sy Adler all provided consistent support to me in the trying period of analysis and writing. Special thanks are offered to Dr. Norman Wyers, chair of my committee. As mentor, colleague and, most importantly, a dear friend for a quarter of a century, Norm has never wavered in his support of, enthusiasm with, and belief in the importance of this work.

No person has been closer to me in this work than Astrid Schlaps. She, more than anyone, understands its meaning to and significance in my own life and 
professional development. Her love, support and tremendous patience have had no bounds, and I am eternally indebted to her for these gifts.

Finally, my deepest thanks and appreciation go to those rank and filers who graciously shared their experiences with me. Over the years, I have had the distinct honor of being afforded the opportunity to share in the history of this movement with those who were both its leaders and its rank and file. Whether by correspondence, on the phone, or over dinner in homes and restaurants, all have been encouraging of my work and forthcoming with their information and advice. Theirs are stories of tremendous courage and inspiration; of personal pain and political repression. I hope that our profession will someday come to recognize the debt owed them and grant them the honored place they hold in our history. 


\section{TABLE OF CONTENTS}

Acknowledgements

Notes on Abbreviations and Citations iv

Forward: The Past as Present, the Present as Past 1

$\begin{array}{ll}\text { Chapter 1: Introduction } & 19\end{array}$

Chapter 2: Before the Storm 53

Chapter 3: Into the Maelstrom $\quad 87$

Chapter 4: The Rank and File Vs. the Profession 131

Chapter 5: Towards a United Front 179

Chapter 6: Repression, Resistance and Destruction: 210 The Final years

Chapter 7: Conclusions 256

$\begin{array}{ll}\text { Reference List } & 267\end{array}$

$\begin{array}{ll}\text { Appendix } & 300\end{array}$ 


\section{Note on Abbreviations and Citations}

Citations for all materials referenced in chapter notes are found in the Reference List. Full citations are provided initially for each reference in chapter notes, and abbreviated thereafter. In addition to abbreviations found in the text, the following abbreviations are used in the chapter notes.

\section{Archives and Manuscript Collections}
AIMS
American Institute for Marxist Studies
New York City, NY
$\mathrm{CPH} \quad$ Communist Party USA Headquarters
New York City, NY
NPML Niebyl-Proctor Marxist Library for Social Research
Oakland, CA
SWHA Social Welfare History Archives
University of Minnesota, Minneapolis, $\mathrm{MN}$

\section{Organizations and Programs}
AASW
American Association of Social Workers
AFGE
American Federation of Government Employees
AFL
American Federation of Labor
AFSCME American Federation of State, County and Municipal Employees
AFSW Association of Federation Social Workers (see AFW)
AFW Association of Federation Workers
CCC Civilian Conservation Corps
CIO Congress of Industrial Organization
CP Communist Party (also referred to as Communist Party of America and Communist Party USA)
CRC Civil Rights Congress 
CWA Civil Works Administration

DPOWA Distributive, Processing and Office Workers of America

FERA Federal Emergency Relief Administration

HRB Home Relief Bureau (New York City)

HUAC House Un-American Activities Committee

IPA Interprofessional Association for Social Insurance

JCTUSW Joint Council of Trade Unions in Social Work

NASW National Association of Social Workers

NCC National Coordinating Committee of Rank and File Groups in Social Work

NCSW National Conference of Social Work

NIRA National Industrial Recovery Act

NMU National Maritime Union

SCMWA State, County and Municipal Workers of America

SEIU Service Employees International Union

SRA State Relief Administration (California)

SSEU Social Service Employees Union

SWAC Social Work Action Committee

TUUL Trade Union Unity League (previously Trade Union Education League)

UFWA United Federal Workers of America

UOPWA United Office and Professional Workers of America

UPWA United Public Workers of America 
WPA Works Progress Administration

Journals

JPHS Journal of Progressive Human Services

JSSW Journal of Sociology and Social Welfare

LH Labor History

RHR Radical History Review

SWT Social Work Today 


\title{
FOREWORD:
}

\section{THE PAST AS PRESENT, THE PRESENT AS PAST}

\author{
April 14, 1966
}

Mr. B. J. Zukas

East Northport Junior High School

East Northport, New York

Dear Mr. Zukas:

I have been reading with interest a book entitled, Three Kids in a Cart by Allen Drury which was secured from the East Northport Public Library. On papers 5, 6 and 7, I note the interrogation of a witness named Bronislaus Joseph Zukas. Are you the witness to whom reference is made? If so, and since the book is undoubtedly being widely read in the community, there may be questions raised by the readers. At least, I would anticipate this might occur.

In order to be prepared for such an eventuality, and if, in fact, you are the witness to whom reference is made, I would appreciate your reaction to the case as presented in the book, the general nature of the investigation, the outcome, and your particular role.

Sincerely,

John G. Benfer

Assistant for Curriculum

April 28, 1966

Dear Mr. Zukas:

This letter is to acknowledge receipt of your brief letter to me and your letter to Dr. Schneider ...in which you submitted your resignation. In my letter of April 14, 1966 to you I indicated that I wished:

a. To know if, indeed, you were the witness to whom reference was made.

b. Your reaction to the case in point as presented by the author.

c. The general nature of the investigation.

d. An explanation of your role.

At our conference of April 21 the foregoing points were discussed verbally. At the conclusion of our conference I asked that you respond in writing to the questions raised in my letter of April 14. This you agreed to do but I assume from your letter of April 26 that you decided otherwise. Again, I would request that you respond in writing to the questions I raised in the letter of April 14. I would expect such an explanation on or before May 5, 1966 , if you choose to comply.

Sincerely,

John G. Benfer ${ }^{1}$ 
Bronislaus Zukas' involvement in social work's rank and file movement was a short but well publicized one. ${ }^{2}$ Like many others who would form the backbone of the movement, Zukas was a public relief worker. Trained as a teacher, Zukas graduated from college and, in the face of the Great Depression, held out few prospects in 1935 for obtaining employment as a teacher in New York City. Instead, Zukas, like thousands of other unemployed white and blue-collar workers, accepted a position as a public relief worker. Like Zukas, most of these new public relief workers did not have the benefit of social work training or a professional degree in social work. Rather, they were thrust into the role of caseworker by virtue of their unemployment and the opportunity for work created by the Roosevelt administration's funding of public relief programs such as the Federal Emergency Relief Administration (FERA) and the Works Progress Administration (WPA). ${ }^{3}$

Zukas worked as a caseworker in the New York Home Relief Bureau, and quickly joined the Association of Workers in Public Relief Agencies (AWPRA). Organized initially in 1933 as the Emergency Home Relief Bureau Association, AWPRA was one of the first, and most militant, of the early rank and file public worker unions. Through contacts in the union, Zukas joined the Communist Party and, like many of the communist group in the union, became a part-time labor organizer.

Following the formation of the Congress of Industrial Organizations (CIO) and the subsequent affiliation of most social work unions into the CIO, Zukas was employed as a CIO organizer and was transferred to California. In California, the 
State, County and Municipal Workers of America, CIO (SCMWA) was engaged in a massive and largely successful effort to organize public sector workers. After leading a campaign to organize hospital workers in Los Angeles, Zukas went to work as a caseworker in Visalia at the Tulare County office of the State Relief Administration (SRA). There, Zukas assumed union leadership as financial secretary for the SCMWA local.

Tulare County, like many other areas of California, was highly dependent on agriculture for its economic base. Over the years, a strong coalition of producers, canneries and distributors had waged a bitter war with migrant workers and efforts of the $\mathrm{CIO}$ to organize farm and cannery workers. Like many $\mathrm{CIO}$ activists and their unions, Zukas and his SCMWA local openly assisted the organizing efforts of the CIO's United Cannery, Agricultural, Packing and Allied Workers of America (UCAPAWA) in Tulare County and the greater Central Valley. However, the growing statewide success of the UCAPAWA did not go unchallenged by agribusiness interests and their allies in the California legislature, who charged that the Communist Party controlled the union. ${ }^{4}$

As alarm over the successes of the UCAPAWA and its alleged communist connections increased in the state legislature, so did charges that the State Relief Administration was riddled with communists. These allegations were directly tied to charges that SCMWA was engaged in such subversive activities as providing relief to striking farm workers and supporting efforts of the Communist-led organization of the unemployed, the Workers Alliance. Citing previous conclusions of legislative 
investigative committees that "...the SRA is being used for the development of the Communist program," the legislature's Assembly Relief Investigating Committee, chaired by Samuel Yorty, launched a series of investigatory hearings in 1940 throughout the state targeting the State Relief Agency and its SCMWA represented employees. $^{5}$

On March 21 and 22, 1940, the committee held hearings in Visalia on alleged communist infiltration of the Tulare County SRA office. As members of the Ku Klux Klan demonstrated outside the hearings, Zukas responded to a subpoena to appear before the committee. In a hearing packed with spectators and reporters, Zukas sparred with investigators, refusing to answer questions about union activities or to turn over demanded lists of union officers and members:

For my 'good deeds' as a CIO organizer, I was the first victim of the witch-hunters' Yorty State Committee on Un-American Activities here...I remember the yahoos gloated as they mispronounced [my name] with the suggestion that no native born patriot would ever bear such a foreign label...

Cited for contempt, Zukas was arrested and jailed following the conclusion of the hearing. While Zukas' subsequent conviction for contempt was overturned on appeal (along with convictions of 19 other witnesses who refused to cooperate with the Yorty committee), his career as a relief worker was over. The publicity of his trial and conviction, coupled with an informal blacklist that circulated among relief agency administrators, effectively barred Zukas from obtaining employment in public welfare agencies. After a ten year period of temporary jobs and self-described “...vegetation and near emotional breakdown," Zukas eventually returned to public 
life, this time as a teacher in Long Island and an activist within the American

Federation of Teachers. ${ }^{7}$

Zukas relished his renewed career as a junior high school teacher, until a

twist of fate permanently ended his professional ambitions:

Even Allan Drury remembered [me] in his pot-boiler memoirs, Three Kids in a Cart...Believe it or not he was a cub reporter in the San Joaquin Valley in 1940 when the Un-Americans attacked me and mine. This was published about 1965 and my school employers called me in to inquire could I be the Bronislaus $\mathrm{J}$. Zukas described therein because the local Birchers were very concerned about such a wild-eyed subversive in their midst as a junior high school master! Of course I admitted to this notoriety and assured them that I was resigning... ${ }^{8}$

With two careers now destroyed, Zukas returned to California, settling in Berkeley.

Despite his experiences with the hysteria of anti-Communism, Zukas continued his activism into the 1980s, participating in the nuclear disarmament movement, protests against the Vietnam war and community organizing efforts among poor people in the

Bay area. Reflecting back on his time in the rank and file movement, Zukas recalls,

Because of our industrial union approach, we were able to capture the spirit of militancy that social workers were looking for. In California, as elsewhere, we concentrated on public and private social worker agencies and institutions...the union survived because the national organization was relatively strong in comparison because few other areas were subjected to such an attack. The rank and file were a very mobile type accustomed to temporary lay-offs and dismissals...In the long run you could say we didn't do a good job of understanding how powerful our enemies were, or what they could do to us, but we were still right...

Generally, the so-called liberal M.S.W.'s were relieved to be rid of subjective and subversive staff malcontents. The ones who headed the relief agencies both here and in the east used to mock our puny 'mock worker' tactics and programs. Just like the AASW 
[American Association of Social Workers], they feared they too would suffer the fate of the genuine radicals who strove to pursue the search for truth and progress...

Mr. Travenner: Will you tell the committee, please, whether or not in 1954 there was a group organized in Hartford known as the Connecticut Volunteers for Civil Rights?

Verne Weed: Given the nature of this hearing, that is the kind of question I want to claim the fifth amendment.

Mr. Travenner: Well, you speak in a very general way about it.

Verne Weed: I have done what I could for peace. That specific question I would claim the fifth amendment on ...

Mr. Travenner: Actually, you were the local head of that chapter or organization, were you not, known as the Connecticut Volunteers for Civil Rights?

Verne Weed: Well, I will repeat again, I did what I could for peace. In terms of that particular question, given the kind of hearing this is, I claim fifth amendment privilege.

Rep. Kearney: What do you mean "the kind of hearing this is"?

Verne Weed: You want to know my opinion? I was subpoenaed here. I was brought here.

Rep. Kearney: That is right. You are here under subpoena.

Verne Weed: And I consider it an undemocratic committee inquiring into the area of opinions, ideas...

Rep. Kearney: I have heard that line before...you are bordering on contempt... ${ }^{10}$

Between 1945 and 1957, the U.S. House of Representative's Un-American Activities Committee (HUAC) crisscrossed the country, holding hearings on the 
alleged infiltration of communism and the Communist Party into almost all aspects of American life and institutions. During this period, the Committee would hold over 230 public hearings and call some 3,000 people before them to testify. ${ }^{11}$ While the press and public would be most enthralled by the Committee's investigation of subversion in Hollywood and alleged Soviet spies in the federal government, the bulk of the Committee's activities focused on the less sensational aspects of alleged communist subversion. For every Dalton Trumbo or Alger Hiss that was called before the Committee, hundreds of ordinary working Americans faced the juggernaut of anti-communism aptly described by National Guardian editor Cedric Belfrage as "The American Inquisition." 12 Most of the witnesses subpoenaed by the Committee did not star in the movies or hold high positions of government; rather, they led ordinary lives and worked in ordinary jobs. They were social workers, teachers, machinists, miners and secretaries. Some were members or former members of the Communist Party, most were not. Many had at one time in their past belonged to liberal or left-progressive organizations such as the American Civil Liberties Union, the American Student Union, the Consumer's League, or the American Labor Party - deemed by the Committee as Communist fronts. Many more were union members or officers of unions, particularly within the Congress of Industrial Organizations, condemned by the Committee as Communist-dominated.

For many of those called before the HUAC, it presaged public humiliation and suspicion, community hostility and censure, termination of employment and the ruin of chosen careers. Blacklists, both formal and informal, would follow witnesses 
and their supporters for years. For some who refused to cooperate, indictments of contempt would lead to prison sentences or long years of expensive legal battles. While the final toll of ruined careers and lives left in the wake of the Committee is unknown, many social workers, such as Verne Weed, faced the Committee and suffered from the culture of fear it helped to create.

In 1956, Verne Weed was the assistant executive supervisor of Children's Services of Connecticut. A graduate of the New York School of Social Work, Weed had started working with Children's Services in 1940 as a supervisor. Well respected by her colleagues and agency administration, she had moved up the ladder of agency leadership and was now responsible for the statewide coordination of foster care and adoption services.

However, it was not the consistently excellent performance evaluations she received that brought Weed to the attention of the U.S. government, but rather, her political activities as a private citizen. A vocal proponent of both the union and peace movements, Weed was well known in Connecticut progressive circles as an activist; and that activism would become the focus of the HUAC in 1956. Named by a cooperative HUAC witness as a member of the Communist Party and as an organizer of Communist front organizations raising funds for the Smith Act defendants, Weed recalls that local newspapers pilloried her as proof of how the “...red menace in Connecticut was infiltrating social services and preying on vulnerable children." ${ }^{, 13}$ In the face of lurid publicity, Weed resigned from her position, entered the doctoral program at the New York School of Social Work, and 
began preparing for her stormy appearance before the Committee in February, $1957^{14}$

Years later, Weed would recall the impact of the HUAC investigation on her career and the response of her profession:

Yes, I was a Communist with a big 'C.' I was a Communist and a social worker, a bad combination back then. Actually, I'm not sure which was worse! Social workers have always been associated with progressive thinking - look at Jane Addams and how she was red-baited after World War I - but now we were part of a global conspiracy subsidized by Moscow. I never saw any of that gold and I don't know what the conspiracy was supposed to be about, unless it was for world peace and social justice. That was what we progressive social workers fought for in our unions and our communities - that was my crime...

I couldn't get a job in Connecticut. It was years before I began to recover professionally, I never did [in terms of] income and professional recognition. Being called a Communist and hauled before the Committee in the middle of my doctoral studies didn't exactly endear me to the professors or other students. Sure, some people understood the fuller implications of what was happening to me and thousands of others, but most were just plain scared ...The profession? They were scared shitless - what were a few red social workers to them? ${ }^{15}$

Despite public attacks made upon her by HUAC, and less public attacks made upon her by some members of the social work profession, Weed continued to act upon her political commitment throughout the rest of her life as both an anti-war activist and community organizer. As a member of the Radical Alliance of Social Service Workers in New York City during the 1970s and early 1980s, Weed became an important link between the Old Left and the activism of a new generation of radical social workers. 
Somewhere a door blew shut. I came back to New York in the fall of 1941 , expecting to be as busy as ever, and there was no work ...

In the fall of 1942, there was no doubt that I was unemployed. At first, I had thought it was the effect of war... When, however, a letter I sent to the Red Cross, which was begging for qualified supervisors, brought no reply, I realized that there might be, in the background, a boycott of my ideas. ${ }^{16}$

Within the course of two decades, the career of Bertha Capen Reynolds careened from the heights of professional prestige to the depths of professional rejection and blacklists. During the 1920 s and early 1930 s, Reynolds was one of the rising stars in social work. A faculty member at Smith College, Reynolds was widely published in the professional journals of the day and a frequent speaker at social work conferences. An early enthusiast for the integration of psychoanalytic theory into social casework, Reynolds was well regarded in the inner circle of the growing field of psychiatric social work. Despite her relative renown in the psychiatric community, Reynolds' embrace of psychoanalytic theory subtly differed from the approach of others. Unlike many of her contemporaries, who privileged a narrow intrapsychic orientation towards diagnosis and treatment, Reynolds struggled to articulate a holistic form of social casework that incorporated psychoanalytic principles within an understanding of the environmental context of individual troubles. $^{17}$

As the extent of social and economic wreckage brought by the Great Depression continued to expand, Reynolds' dissatisfaction with what she considered 
the seeming disconnect between social work theory and the environmental realities

of human suffering also grew:

It is certain that a procedure called 'passivity' was in vogue in casework...Theories justifying leaving the initiative and responsibility to the client were carried to such amazing lengths that in a few years revolt came, and the 'passive approach' was changed to 'dynamic passivity,' and that was defined and applied according to the needs of caseworkers as variously as 'passivity' had been. ${ }^{18}$

Reynolds' growing discontent with the profession's response to the national economic crisis would soon lead her to embrace both the program of industrial unionization promoted by the emerging rank and file movement in social work and the Marxist philosophy that many in the movement espoused:

During the seven years from 1934 to the outbreak of war at the end of 1941, I was growing slowly, but fortunately...in company with a vital young generation of social workers. The simple principles that the so-called rank-and-file workers of the Depression years were putting into practice were not new to social work. It was only a new thing to take them seriously...

The rethinking of our professional theory and practice may seem...to have had two roots: its own professional development in a time of depression which forced new formulations under new conditions; and the Marxist science of society which guided the thinking of some of the leaders of the 'rank-and-file' movement...Our profession could not develop otherwise than in conformity with the laws of motion of human society in general...Fortunately for social work, in this critical period, [came] practitioners with Marxist vision and scientific understanding. ${ }^{19}$

Following her introduction to the rank and file movement, Reynolds rapidly became one of its most outspoken proponents within the profession. Reynolds became a frequent contributor to Social Work Today, the journal of the rank and file, 
as well as serving on its editorial board and leading fundraising efforts to ease its chronic financial troubles. Travelling throughout the country, Reynolds forcefully supported the program of the rank and file movement, industrial unionism, civil rights and other progressive movements and causes. As Reynolds' commitment to revolutionary socialism deepened, she sought to more fully incorporate her adherence to the principles of Marxism and Freudianism into a theory of social work practice in a series of published and unpublished works. ${ }^{20}$

However, Reynolds' conversion to Marxism, and her public support for the more radical wing of the rank and file movement, would rapidly engender reaction from the profession and its liberal leadership. Increasingly, social work leaders such as Grace Marcus, Linton Swift, and Dorothy Kahn pointedly and publicly distanced themselves from Reynolds, attacking her adherence to radical ideology and causes. By 1938, the deep rift between Reynolds and the mainstream profession encompassed her work as Associate Director at the Smith College of Social Work. Sharp conflict arose between Reynolds and Director Everett Kimball, leading to Kimball's termination of an experimental teaching program developed by Reynolds. Faced with the withdrawal of Kimball's support, Reynolds resigned under pressure from Smith. In 1958, Reynolds would reflect upon her de facto dismissal from Smith:

I know EK [Everett Kimball] was in terror of 'union action,' and tried to cover himself at every point, so that no one would say I had been fired... a movement got started among alumnae to urge Smith to award me an honorary degree. I stopped it with this appraisal: One of two things is true. Either I'm being fired, in 
which case Smith would do no such thing, or I am resigning because I disapprove of the conduct of the School, in which case I would not accept an honor from it. ${ }^{21}$

Reynolds' departure from Smith would mark the beginning of a long journey that, while endearing her to the rank and file and the radical left, permanently estranged her from the mainstream profession. As an informal blacklist within the profession enveloped Reynolds, her career over the next three years was reduced to one of itinerant consultation. By 1941, Reynolds' open association with the Communist Party virtually ended any official role or recognition that remained for her within the profession. Finding employment in social work schools or agencies impossible to obtain, in 1943 Reynolds joined the Personnel Department of the leftled National Maritime Union (NMU). Here, in the midst of a politically progressive union, she could more freely experiment with her new vision of a radicalized social work. But with the end of World War II, as anti-Communist purges wracked the NMU and other CIO unions, Reynolds once again found herself isolated and unemployed. ${ }^{22}$

As the repressive politics of the Cold War and McCarthyism gripped the nation, Reynolds recognized that her career as a professional social worker was now at an end. Retiring to her family home in Massachusetts, Reynolds remained an activist in progressive political movements and causes and continued her writings on the merits of social work unionization and the integration of Marxism into social work theory. While remaining true to her radical ideology, Reynolds also understood that, to the profession, she had become a virtual pariah: "I knew that 
discussion groups with me have been banned because of fear. Some group invitations I may have to refuse because I know that attending them would subject some people to loss of jobs, or worse."23 Reynolds' open association with progressive organizations was noted with alarm not only by the profession but by state and federal subversive activities investigators as well. Indeed, meticulous records were kept on Reynolds' associations with alleged subversive organizations, resulting in some forty citations by HUAC for membership in and association with those organizations. ${ }^{24}$

Ostracized by the profession, and her loyalty under question by the government, Reynolds essentially passed into professional obscurity. Yet in the face of disavowal by her one time colleagues, Reynolds remained loyal to her "beloved profession" and her vision of its role in a restructured society:

Our profession has worked where it could and, in a world often hostile to its ideals, has sometimes suffered loss of its relatedness to the progressive movements of the life of its time. It has not willingly, however, accepted a role exploitive of its clients, or a police function to keep people quite while they starve slowly...

Suppose social work will become a reaching down to individuals on the part of a healthy society, concerned that minor adjustments shall be well made when planning for thousands cannot be exactly right for every single person. Can we not rejoice to be that helping hand? If groups functioning healthily help each other along as naturally as do parents and children, friends and neighbors, must we be exclusive about the privilege of helping? $?^{25}$ 


\section{Notes to Foreword}

1. Copies of letters provided to the author by Bronislaus Zukas, July 25, 1980. Unless otherwise noted, information on the experiences of Mr. Zukas was obtained in correspondence and interviews with the author (May 23, 1980; June 14, 1980; July 25, 1980; August 11, 1980; August 18, 1980; September 28, 1980; October 14, 1980).

2. The term "rank and file movement" will be used throughout this study to denote the social work trade union movement. The term was a self-descriptive label coined by its leaders and intended to demonstrate the movement's emphasis on support of and membership in the industrial vs. craft union organizing efforts of the 1930s. See: Jacob Fisher, The rank and file movement in social work (New York: New York School of Social Work, 1936).

3. FERA and the WPA were two federal programs created in response to the economic crises of the Depression. FERA, established in May, 1933, provided federal funding matched by states to provide direct relief to the unemployed. State and county FERA offices employed both trained social workers and uncredentialed relief workers to assess need and provide financial assistance to qualified applicants. The WPA, authorized by Congress in 1935, established a massive national program of work relief through public works projects. Following the termination of FERA in 1935, many FERA staff were absorbed into these works programs. See: Harry Hopkins, Spending to save (Seattle: University of Washington Press, 1972); and Tom H. Watkins, The Great Depression: America in the 1930s (New York: Little, Brown and Co., 1993).

The employees of FERA offices were a primary focus of initial rank and file union organizing efforts and formed the base for subsequent organizing of city and state public welfare agencies. Efforts to organize WPA workers were largely led by the Workers Alliance of America, a national coalition of unemployed workers councils. Working closely with the Communist Party in this effort, the Alliance was only marginally successful in the establishment of quasi-unions of WPA workers. While not a focus of organizing efforts by the social work rank and file movement, unions representing social workers and public relief workers lent both material and moral support to the efforts of the Alliance to organize WPA workers (Herbert Benjamin, "After a decade of mass unemployment," The Communist (March 1940), pp. 259-277; Franklin Folsom, Impatient armies of the poor (Niwot, CO: University Press of Colorado, 1991); interview by author with Abram Flaxer, August 16, 1980).

4. For a first hand account of the California farm worker movement in the 1930s and 1940s, see Dorothy Healey and Maurice Isserman, California red (Chicago: 
University of Illinois Press, 1993).

5. E. L. Barrett, The Tenney Committee: Legislative investigation of subversive activities in California (Ithaca: Cornell University Press, 1951); K. Uhl, "Union worried by cleanup plans," Visalia Times-Delta (October 3, 1939), p. 1; K. Uhl, "CIO dominating state relief office," Visalia Times-Delta (December 13, 1939), p. 3; State, County and Municipal Workers of America, California Division, While you're not looking [Pamphlet] (San Francisco: SCMWA, 1940).

6. Correspondence from Bronislaus Zukas to author, June 14, 1980. See also: State of California. Legislature Assembly. Relief Investigating Committee, Report on subversive activities (Sacramento: California State Printing Office, 1940).

7. "vegetation" quote and block quote from Bronislaus Zukas (correspondence with author, June 14, 1980); "McGowan brands Yorty committee as red baiters," Visalia Times-Delta (March 23, 1940), p. 1; K. Uhl, "Complaint is issued after Yorty committee concludes two-day hearing: Others in SRA facing prosecution," Visalia Times-Delta, (March 23,1940), p. 1; State, County and Municipal Workers of America, Local 204, Statement by Local \#204 of the State, County and Municipal Workers of America given to the Yorty Committee at the Visalia hearings on March 21 and 22, 1940 (mimeograph, 1940).

8. Bronislaus Zukas, correspondence with author, August 28, 1980. At the time of the Visalia hearings Allan Drury was editor of The Tulare Bee, a local newspaper. Drury later named Zukas as a witness in a recollection of the hearings published in Three kids in a cart: $A$ visit to Ike, and other diversions (Garden City, NY: Doubleday \& Co., 1965), pp. 1-11.

9. Interview of Braunislaus Zukas by author, October 14, 1980. The AASW was the major professional association of social workers in the 1930s and 1940s.

10. Testimony excerpted from: U.S. Congress. House Committee on Un-American Activities, Investigation of communist activities in the New Haven, Conn. Area (1957), pp. 193-198. Unless otherwise noted, information on Verne Weed obtained from correspondence and interview with author, March 31, 1980; April 18, 1980; May 4, 1980; and July 21, 1980.

11. C. Beck, Contempt of Congress: A study of prosecutions initiated by the Committee on Un-American Activities (New York: De Capo Press, 1959), p. 14. In fact, the HUAC would continue to investigate alleged subversion into the early 1960 s, eventually losing public support and, finally, congressional funding. 
12. Cedric Belfrage, The American inquisition, 1945-1960 (New York: Thunder's Mouth Press, 1989). Belfrage was himself a notable victim of HUAC investigations. Following his refusal to cooperate with HUAC and Senator Joseph McCarthy's Permanent Sub-committee on Investigations of the Senate Committee on Government Operations, Belfrage was expelled from the country in 1955 as a "dangerous alien." A vigorous but unsuccessful campaign to prevent Belfrage's expulsion was waged, particularly by the American Committee for Protection of Foreign Born (ACPFB). Rank and file social worker Mary Van Kleeck, a member of the ACPFB, was highly effective in soliciting protest from prominent social workers and social work trade unions. Van Kleeck was a friend of Belfrage and had served as administrator for the National Guardian's emergency fund raising efforts in the late 1940s (pp. 137, 187).

13. Interview by author with Verne Weed, May 4, 1980.

14. Weed was aggressively questioned by HUAC over her role as a member of the Connecticut Volunteers for Civil Rights and Freedom of the Press, groups that were among many local and national organizations established upon the urging of the Communist Party to raise funds and public support for the Smith Act defendants.

In July of 1948, twelve members of the Communist Party's National Board were indicted on charges of "teaching and advocating the overthrow of the United States government by force and violence" through their membership in and leadership of the Communist Party. The basis for the subsequent trials and convictions of eleven of the defendants was the Alien Registration Act, popularly known as the Smith Act (the twelfth defendant, William Foster, was severed from the trial due to illness). Ten of the eleven convictions were subsequently upheld by the Supreme Court. Over one hundred members of the Communist Party would eventually be indicted and tried on Smith Act charges. See David Caute's The great fear: The anti-Communist purge under Truman and Eisenhower, (New York: Simon and Schuster, 1978), pp. 185-215; William Z. Foster, History of the Communist Party of the United States (New York: International Publishers, 1952), pp. 509-518; and Joseph R. Starobin, American communism in crisis, 1943-1957 (Cambridge: Harvard University Press, 1972), pp. 196-197, 241.

15. Interview by author with Verne Weed, July $21,1980$.

16. Bertha C. Reynolds, An uncharted journey (New York: Citadel Press, 1963), pp. 231, 237-238. 
17. Ibid., pp. 98-134; Bertha Reynolds, "The role of the psychiatric social worker in therapy," In Proceedings, First International Conference of Mental Hygiene, Vol. 1 (Washington, D.C.: International Conference of Mental Hygiene, May 1930), pp. 46-69.

18. Reynolds, An uncharted journey, pp. 138-139.

19. Reynolds, An uncharted journey, p.173, 181. Reynolds attraction to Marxism would also lead her to join the Communist Party, remaining an active member until her death. See: Bertha C. Reynolds Papers, Sophia Smith Collection, Smith College, Series IV, Box 11, Folder \#123: "Communist Party"; Bertha C. Reynolds Papers, American Institute for Marxist Studies; Bertha Reynolds Club papers, Communist Party USA Headquarters.

20. Regarding Reynolds' work with Social Work Today, see An uncharted journey, pp. 155-158. Reynolds' attempts to develop a radical integration and critique of social work theory resulted in a prolific output of articles and books, most notably: "Whom do social workers serve?" Social Work Today (May 1935), pp. 5-8; "Rethinking social casework," SWT (April, May, June 1938), pp. 5-8;5-7; 57; "Social workers and the democratic process," SWT (October 1939), p. 4; and Learning and teaching in the practice of social work (Silverspring, MD: National Association of Social Workers, 1985).

21. Sharon Freedberg, Bertha Capen Reynolds: $A$ woman struggling in her times (unpublished dissertation, Columbia University, 1984), pp. 131-132. Block quote of Reynolds as cited in Freedberg, p.148.

22. For a fascinating account of Reynolds' time in the NMU, see B. C. Reynolds, Social work and social living (Silverspring, MD: National Association of Social Workers, 1987).

23. Reynolds, quoted in Freedberg, Bertha Capen Reynolds: $A$ woman struggling in her times, p. 176.

24. U.S. Congress, House Committee on Un-American Activities, Communist political subversion, $84^{\text {th }}$ Congress, $2^{\text {nd }}$ Session (1953).

25. "beloved profession" quote and block quote from: Reynolds, An uncharted journey, p. 323. 


\section{CHAPTER 1: INTRODUCTION}

We social workers often delude ourselves into a belief that we are important factors in the remaking of society...our work is essentially for the existing social order-not against it. We are either case workers patching up the evils and the miseries of the industrial system; or propagandists for reform legislation; educators; collectors of facts and figures; or neighborhood and community workers. In all these activities we work with and tacitly sanction the existing political and industrial system. We do not challenge, nor do we oppose, the underlying bases of that system, as do all radicals. Our work is undemocratic at heart...

(Roger Baldwin, 1918)

During the period of the late 1920 s through the late 1940s, a most remarkable event in the history of American social work emerged: the development of a vital radical trade union organizing effort known as the "rank and file movement."" Born within the growing economic crisis of the 1920 s and maturing in the national economic collapse and social upheaval heralded by the Great Depression, the rank and file movement would attract the support and membership of thousands of professional social workers and uncredentialed relief workers in efforts to organize social service workers along the lines of industrial unionism. Within its relatively short life span, the rank and file movement would grow in sufficient number and influence to challenge both the prevailing definitions of social work as a profession its form and identity - and the essence of its function - its practice.

Such challenges would not go unnoticed or unanswered by the profession's mainstream leadership or, more importantly, by state and federal authorities. To many of the profession's leaders the rank and file movement would come to represent the antithesis of professionalism: over-identification with clients; the 
advocacy of strikes and other militant, unprofessional forms of protest and political action; a seeming disdain for prevailing professional standards of education and training; and an unnatural curiosity regarding left-wing political ideology.

For civil authorities, the movement provided further evidence of the alleged infiltration of the Communist Party and communist ideology into the labor movement and, perhaps most alarming, white-collar professions. Such evidence would come to include the rank and file's early criticism of New Deal policies and programs (as well as state and local relief administration and practice) as politically reactionary and insufficient in scope, their seeming obedience to the shifting policies of the Communist Party and pronouncements of the Communist International ${ }^{3}$ and their unabashed willingness to embrace the potentials of foreign economic and political theories. Equally damning, social work unions and their leadership were too often at the forefront of political causes deemed by authorities as subversive and too prominently represented as members and supporters of organizations labeled as fronts for the Communist Party.

While such perceived professional and political heresies would quickly form the objective basis for the eventual unraveling of the movement, these perceptions neither accurately describe nor fully explain the history and meaning of the rank and file movement in the profession and within the greater context of its times. Rather, they represent, perhaps more tellingly, the paradox of historical inquiry and the needs of both historical actors and the tellers of historical stories to provide definitive reasons for the causes and courses of human events and social movements. Indeed, 
definitive reasons provide history and historical actors the supposed truths of both culpability and absolution; they provide simplified and contained explanation to the meaning of facts. In this regard, C. Wright Mills has noted that, ...we must accept the point that we must often study history in order to get rid of it. By this I mean that what are often taken as historical explanations would better be taken as part of the statement of that which is to be explained. ${ }^{4}$

The story of the rank and file movement in social work highlights Mills' observation that many explanations of historical events or movements often serve to obscure rather than illuminate both the deeper meaning of these events and their ongoing influence upon contemporary thought and process. Indeed, contemporary historical accounts of the rank and file movement in social work, while few in number, have well represented this tendency to confuse historical explanation with historical subject and to separate the past from the present. This study attempts to bridge this rupture by more fully examining both the subject of the rank and file movement and its ongoing meaning and place in the profession's development than has previously been rendered. Indeed, it is the thesis of this study that the social and economic circumstances in which the rank and file movement arose within social work (and the forces which led to its demise) are central to an understanding of the profession's emerging character and subsequent evolution. The rise and fall of the rank and file movement did not occur just within the isolated context of social work as a profession; it embodied expressions of broader social and political contradictions that characterize a society in crisis and transformation. As such, the 
history of the rank and file movement is not one of just a particular tendency within a particular profession in a particular time; rather, it demonstrates how the forces that give rise to such a social movement transcend these particulars and are inextricably woven into the greater social fabric of a nation's history. In the case of the rank and file movement in social work, uncovering the ongoing dynamics of this history must necessarily cross traditional boundaries of historical inquiry. For the history and meaning of the rank and file movement in social work is not just of the field's understanding of professionalism, its experiences in the process of professionlization or its development of a body of expertise. The story of the rank and file also embodies a broader history of the struggles of organized labor, the relationship between liberal social reform movements and revolutionary movements, and the politics of communism and anti-communism in the American experience. This broader interpretation is, in sum, a significant element of the history that constitutes the social basis of American social work.

\section{On the Historical Record}

The case of the rank and file movement and its place in social work history is a curious one. Standard texts concerning social work and social welfare history have, at worst, ignored the movement completely; at best, they have granted it a momentary but essentially nebulous impact. For example, Clark Chambers' Seedtime of Reform makes no direct reference to the early stirrings of the movement in his history of the profession's development in the period following World War I through the early years of the New Deal. ${ }^{5}$ Similarly, Chambers' Paul U. Kellogg 
and the Survey has only one passing reference to the movement devoid of explanation or context. ${ }^{6}$ The rank and file movement is totally ignored in June Axinn and Herman Levine's Social welfare: $A$ history of the American response to need. ${ }^{7}$ Remarkably, even Harry Lurie, an early and influential leader of the rank and file movement, makes no mention of the movement at all in his history of the Jewish Federation Movement, $A$ heritage affirmed. ${ }^{8}$ Another recognized social welfare historian, Walter Trattner, briefly mentions the rank and file movement as a group "unhappy" with the Roosevelt administration and its New Deal policies, and he cites its major accomplishment as "...forging some ties between social work and organized labor." Bruce Jansson devotes one paragraph to the movement in his text, noting its development of unions and support of "sweeping social reforms," Simon sparingly describes the movement as "...a vociferous and determined minority," curiously attributing its demise to the passage of the Social Security Act and the lack of attention given to social work demands by the Democratic and Republican parties. ${ }^{11}$

Other less prominently used texts concerned with social work's development have paid greater attention to the importance of the rank and file movement but have fallen well short of either a balanced or comprehensive account. John Ehrenreich devotes several pages to the movement in The Altruistic Imagination. ${ }^{12}$ Most significantly, Ehrenreich credits the rank and file movement with providing the profession its "most direct challenge" to its preoccupation with the process of professionalization. ${ }^{13}$ Ehrenreich also credits the rank and file movement with 
unionizing a "significant" segment of the profession and pushing it "...toward a more critical and aggressive stance with respect to public policy issues." ${ }^{14}$ However, not unlike Simon, Ehrenreich confines the movement's meaning to a static period in the profession's history, declaring that its failure to articulate a clear alternative practice theory quickly rendered it irrelevant.

Wenocur and Reisch devote a chapter to the rank and file movement in their history, From Charity to Enterprise. ${ }^{15}$ Framing their analysis of social work's development as a case study of how the dynamics of capitalism institutionalize professions for the purposes of occupational control (and thus define the process of professionalization), Wenocur and Reisch position the rank and file movement as a “...progressive counterforce to the profession's attempts to control the emerging national social welfare industry." 16 While providing students of social work history a much needed description of the movement, Wenocur and Reisch's account suffers both from its sketchiness and limited conclusions regarding the impact and meaning of the movement. ${ }^{17}$

More focused studies of the rank and file movement described below, while few in number, have moved beyond the meager generalities of the movement's role as expressed in standard social welfare texts. Indeed, these studies have girded their analyses around four general (and intertwined) topics of particular interest to the profession: (1) the instructive value of the rank and file movement in relation to the process of professionalization and the meaning of professionalism; (2) the place and meaning of the movement in terms of social work's purported dualism regarding 
social reform and individual treatment; (3) the relative compatibility or incompatibility of professionalism and union organization in social work; and (4) the role of the Communist Party and communist ideology in leading and/or misguiding the movement, thus hastening its destruction and subsequently marginalizing its relevance to social work theory and practice.

\section{Professionalism, Social Reform and Unionization}

Within these four overlapping areas of inquiry, the meaning of the rank and file movement in relation to social work's development of a professional identity, its relation to unionization and the issues of the profession's dualism have garnered the most attention. Indeed, the history of social work's development as a profession has been particularly marked by its constant struggle to locate and claim its domains of authority and practice. Since the early emergence of social work as a formal profession, social workers and their historians have debated social work's purpose in society in somewhat stark and dichotomous terms: is social work a profession whose major task is to develop, refine and provide direct psycho-social services, or is it a profession that should be dedicated to serving larger movements for social reform, social justice and resulting social action? Throughout the profession's history, while the language and historical contexts of the debate have changed, the terms of this bitter ideological debate have remained relatively stable. ${ }^{18}$ In this regard, historical examinations of the rank and file movement have both further informed and confused this debate, reflecting the tendency of selective history to reap selective interpretations and claims of truth. 
In a brief history and analysis of the rank and file movement, Leighninger and Knickmeyer claim that the movement informs the profession in areas of both theory and practice. ${ }^{19}$ First, the authors argue that the brief life of the rank and file movement and its rapid demise demonstrate that the nature and process of professionalism is, at its base, inimical to radical ideology and fundamental social reform. In this regard, Leighninger and Knickmeyer additionally posit that the experiences of the rank and file movement highlight the importance of the profession's sponsorship by conservative economic and political structures and agencies; that is, such sponsorship privileges social control functions and allies the profession with the interests of a ruling elite. Reflecting this dynamic within the history of the rank and file movement, the authors assert this is a partial explanation of social work's "...long-standing fear that somehow professionalism and a reform or radical ideology [cannot] exist." ${ }^{, 20}$ Finally, Leighninger and Knickmeyer claim that the history of the rank and file movement demonstrates the need for social work practitioners to individually and organizationally connect themselves to consumer movements in order to effectively engage in social change efforts:

Knowledge of the rank and file experience illuminates three major themes. The social work profession today needs to understand and come to grips with 1) the rise of the consumer movement, 2) the phenomenon of powerlessness shared by a number of groups in our society, and 3) the need for professional support groups in dealing with the inequities in social welfare...In order to do this with any success, it will be necessary to rediscover the rank and file wisdom of finding support for such efforts towards change in organized social work groups and broader social movements, both within agencies and on a national level. ${ }^{21}$ 
Alexander and Lichtenberg credit members and supporters of the rank and file movement with advancing the profession's understanding of the link between social reform and individual treatment. ${ }^{22}$ In an analysis of practice related articles ("The Case Work Notebook") published in the movement's journal, Social Work Today, the authors note that the theory and practice of the rank and file movement simultaneously advanced the profession's understanding of and commitment to: 1) professional development and improved services to clients; 2) the legitimate need of the profession to address broad social issues; and 3) the improvement of the working conditions of social workers as an integral factor in providing effective service to clients. The authors claim that the writings of rank and file practitioners, while predominantly progressive in intent and act, contained both radical and conservative elements. While crediting rank and file practitioners with promoting more radical concepts of democratic authority and worker-client equality, Alexander and Lichtenberg argue that these same practitioners continued to reflect more traditional and conservative impulses of professionalism by privileging social workers' ability to perform social and political analysis over the same capability of those they served:

What was true for the authors of the 'Case Work Notebook' is true of many social workers today too: they are also attached to the status quo and yet eager to bring a new system into existence. The ambivalence in these writings is paralleled by the ambivalence in the field today...It is possible for young social workers to know and to build upon the positive contributions from these vital professional unionists. It is also possible that new times permit the rectification of the omissions, compromises and false directions that undermined their promise of achievement. ${ }^{23}$ 
Wagner echoes Alexander and Lichtenberg's critique of the rank and file's limited influence on professional theory and practice, framing this critique as an exemplar of the inherent politically constraining dynamics of professionalism. ${ }^{24}$ Arguing that the historic process of professionalization within social work has required an alliance (however uneasy) with economic and political elites in order to obtain legitimacy as a profession, Wagner claims that the radicalism of the rank and file movement inexorably dissipated within this process. Linking this dissipation to both the movement's adherence to the Popular Front policy of the Communist Party and the movement's own desires for a distinctive and professionally recognized form of social casework, Wagner claims that the movement's vision of a "proletarianized" social work was converted to "...the viewpoint that good casework was good politics. 25,26

Other analysts have echoed the importance of understanding the rank and file movement in relation to social work's process of professionalization and that of social reform. Phillips and Lehman cite the history of the rank and file movement in their examination into the conflicts and compromises that faced the profession during the New Deal years as the federal government increasingly supplanted private charities as the primary sponsor of social welfare activities. ${ }^{27}$ Contrasting the rank and file movement's opposition to the mainstream profession's alliance with conservative business leaders and social welfare administrators with the need for profession's to preserve its occupational interests and markets, Phillips and Lehman make the following observations: 
The quest for [professional] sanction and power, which ultimately derives from a profession's connections with government, precludes persistent and serious challenges to government policies...

Conflict arises for a profession-occupation which, insofar as it is a profession, is responsible to act in the interest of clients, including political action, and insofar as it is an occupation, needs to protect occupational self interests, including advancement of status. ${ }^{28}$

In a similar vein, Leighninger contrasts the social agenda of the rank and file movement with that of the mainstream profession in her history of social work's development. ${ }^{29}$ Leighninger notes that with the onset of the Great Depression, the profession split into two distinct trends: the radical program of the rank and file, emphasizing unionism, public policies promoting redistribution of wealth and a fundamental transformation of social and economic institutions; and the more moderate program of reform embodied with the mainstream organization of the profession, the American Association of Social Workers (AASW). Leighninger posits that these two trends, protest and reconstruction versus moderation and amelioration, exemplify long and unresolved tensions framing social work's consolidation as a profession: 1) a focus on profession-building versus public service; 2) the proper relationship between the profession and a public welfare system; 3) the acceptable professional boundaries of political activity; and 4) the relative breadth that the profession's intellectual and practice base should encompass. ${ }^{30}$ While eschewing any definitive conclusions regarding the ultimate implications of the rank and file's full role in the profession's quest for identity 
within these tensions, Leighninger addresses (if somewhat obliquely) the terms of the debate forced upon the profession in the 1930s:

Social workers had temporarily broadened their concerns and moved toward collective political action during the 1930s...The internal debate was affected by outside forces - agency constraints, changing economic conditions and political climate, and shifts in social work's influence within administration circles. Agency and political pressures, and an image of 'true' professionals as nonpartisan and objective, encouraged social workers to choose the expert role over that of political activist. By the end of the decade, the AASW had returned to the more comfortable position of a professional group concerned with professional standards and practice. Outside forces and internal questions about political involvement had combined to limit social work's chances to influence broader social planning. ${ }^{31}$

Spano has examined the rank and file movement in terms of its contributions toward the "...development of an alternative conceptualization of social work as a profession based primarily on a commitment to social reform rather than individualized treatment. ${ }^{32}$ Claiming that the movement's social activism was guided by a Marxist ideology, Spano credits the rank and file with providing social workers of the 1930s a credible challenge to psychiatric theories of adjustment. Spano also argues that the movement's emphasis on the status of social workers as employees temporarily legitimized the use of labor tactics and unionization among public relief and private charity workers. Despite the apparent importance of these contributions, Spano concludes that the movement ultimately "came and went," exerting little noticeable influence on the profession. ${ }^{33}$

Olson, in an unpublished dissertation, considers the rank and file movement in his examination of the broad relationship between social work and liberal social 
reform causes during and immediately following World War $\mathrm{II}^{34}$ Olson argues that social work's obsession with the need to obtain professional status and recognition, coupled with its allegiance to liberal ideology, seriously vitiated its potential for fundamental social reform in post-war America:

Professionalism, elitism, and the growth of a social work subculture were in part to blame. Social work was never able to transcend its casework, individualized approach or marshal its skills against society's larger social problems...

Social work's own elitism, its claim to special knowledge, moreover, made it unlikely social workers could effectively cooperate with other 'progressive' forces in society. ${ }^{35}$

Unlike other analysts, Olson characterizes the political and trade union agenda of the rank and file movement as neither fundamentally antagonistic to, nor radically different from, the mainstream of the profession. Rather, Olson argues that rank and file conceptions of social action were in keeping with those of most of the profession and that the politics of the rank and file reflected more a difference of kind with the mainstream profession than any fundamental challenge. In fact, Olson dismisses any meaningful variance between the rank and file movement and the mainstream of the profession, claiming "Despite differences, however, no serious cleavages erupted within social work in the Depression decade. What differences there were were largely of degree."36

Several social work historians have examined the rank and file movement in terms of insights it may yield regarding the historic ambivalence that has existed within the profession in relation to union organization. Karger notes this 
ambivalence has several sources, including perceptions that unions are unprofessional, concern that union emphases on employee bread and butter issues may conflict with client interests, and a perceived contradiction between professional notions of self-sacrifice and union insistence on self-protection. ${ }^{37}$ Karger, a strong proponent of social work's affiliation with the labor movement, credits the rank and file movement with legitimizing the compatibility of unionism with social work as a profession. In a brief discussion of the movement, Karger reflects on its legacy:

Through their activities - literature, speeches, and direct action tactics - the rank and file movement exposed large numbers of social workers to the powerful concept of 'organization'...the experience that social workers received in arbitrating grievances, making demands, organizing meetings and rallies, and walking a strike line were valuable skills that could be used in the organized labor movement, as well as in the later civil rights and antiwar movements...In short, the significance of the rank-and-file movement lay in its spadework - the breaking of ground to allow the seeds of social work unionization to take root. ${ }^{38}$

Straussner and Phillips also examine the ambivalence of social work as a profession to organized labor. ${ }^{39}$ Arguing that the prevailing practice of the early Charity Organization Societies, with their emphasis on efficiency, rationality, and morally-based conceptions of poverty, depended on both the material and political support of business leaders, the authors contend this ideological dependence created an early rupture with organized labor. However, the authors further contend that with the onset of the Great Depression, social work adopted a more focused concern on the economic aspects of need and, consequently, a more sympathetic view of unionization in terms of the profession's own economic security issues. 
Interestingly, Straussner and Phillips bifurcate social work unionization from the rank and file movement. While declaring that the unionization process that occurred among social workers in the 1930s helped to bridge the gap between the profession and organized labor, the authors separate the rank and file movement as "another example" of the profession's growing support for unionization. ${ }^{40}$

Leslie Alexander's study of the rank and file movement's organizing efforts in the voluntary sector provides a more detailed examination of the rank and file's legacy to the unionization debate. ${ }^{41}$ Alexander asserts that the movement played a significant role in prodding the professional associations of the time, particularly the AASW, to at least grudgingly accept unionization as a professionally-sanctioned activity. However, Alexander notes that following a period of generally favorable response by the mainstream profession regarding unionization in the voluntary sector, this support rapidly dissipated after 1939 as charges of communist domination of the unions mounted. While noting the influence of these charges upon the shifting attitude of the mainstream profession, Alexander claims that the underlying basis for this turn from unionization had less to do with ideology than with the dynamics of professionalization:

It seemed that the AASW would only tolerate the union as long as it was weak. As soon as it became more successful in collective bargaining and, in fact, threatened to expand the scope of collective bargaining, the profession began to raise the question of whether or not unions were compatible with professions. The answer seemed a conditional yes; on the condition that the union did not get too powerful. ${ }^{42}$ 
To date, the most in-depth history of the rank and file movement has come from one of its early leaders, Jacob Fisher. ${ }^{43}$ As an editor of the movement's journal, Social Work Today, and a social work union leader in the 1930s, Fisher's first-hand account of the early years of the rank and file movement and the greater profession's development during the years of the Depression is an invaluable source to any researcher seeking to develop a fuller history of the movement. Framing the history of the rank and file movement within the greater context of the internal shock and disillusionment faced by a profession unprepared in theory or practice to respond to the Depression, Fisher characterizes the movement as the political manifestation of that disillusionment. In this regard, Fisher emphasizes the role of the rank and file in providing a dissenting voice within the profession through unionization, articulating a vision of social reform reminiscent of the ethos of an early Progressivism. While providing a rich-first person perspective, Fisher's account still falls short of completing the historical record. Despite his leading role in the initial development of the rank and file movement, Fisher left the field in the late 1930s, and his history of the movement substantively concludes at this point. And, not unlike any personal recollection, Fisher's account suffers from both a degree of self censorship and reification, particularly in regard to the question of communism and the rank and file movement - an area of inquiry critical to the movement's history and discussed in more detail below. ${ }^{44}$ Finally, not unlike other assessments of the movement, Fisher also relegates the meaning of the rank and file to a static (and largely hidden) place in the profession's history: 
It left no lasting legacy, but at least it contributed to a heightened awareness among social workers of the need for a broad...social welfare and social insurance system.... guaranteed minimum income...government work and retraining programs for the unemployed...and of the need for health insurance...

Perhaps to see these thumbprints of the future in the not fully articulated causes supported by the Rank-and-File Movement is to exaggerate its contemporary significance. ${ }^{45}$

\section{Have You Ever Been? The Communist Question}

The Rank-and-File movement tried to establish 'protective associations,' that is, unions...These protective associations of the Rank-and-File...became the social-service unions of the Union of Office and Professional Workers of America...This organization may have contained a higher proportion of Communists than any other existing legitimate trade union. It was able to follow the Communist line in detail, and with relatively weak opposition from within the union. ${ }^{46}$

(Nathan Glazer, 1961)

...politics emerges as the decisive element in the history of the Rank and File movement. The particular tactical stance the Rank and Filers took toward national politics was dictated by the Communists and their allies in the movement. This stance...killed the movement as a social work reform movement. And the social worker unions themselves were destroyed...when the strong presence of Communists resulted in debilitating factionalism, expulsion from the labor movement, and the loss of union contracts and recognition. ${ }^{47}$

(John Earl Haynes, 1975)

The role of the Communist Party and communist ideology in the

development and conduct of the rank and file movement has perhaps been the most uncomfortable and contentious of issues for the profession's historians. Indeed, allegations of Communist Party domination of the rank and file movement have uniformly vexed such historical accounts and may be key in understanding the relative marginalization of the movement's history in mainstream accounts of the 
profession. These allegations (and a reluctance to examine them) may be key for the reason that the very act of invoking the specter of communism or Communist Party involvement in social work, whether real or alleged, creates discomfort for both investigators and consumers of that history. In this regard, the contemporary invocation of communism or communist influence in American political discourse often results in seeming visceral reactions, both in civil and scholarly quarters. AntiCommunist crusades in American history, particularly as embodied in the Red Scare following World War I, the early years of the Cold War, and the subsequent era of McCarthyism have wrought long-term and often devastating effects upon both civic and intellectual discourse. The immediate climates of fear and paranoia that permeated these periods, while muted since the end of the Cold War, continue to reverberate.

The tools of hysteria and political repression embodied within antiCommunist movements in the United States have affected to greater or lesser extents nearly all aspects of social institutions and political culture. Investigations into the subversive nature of communism were pervasive in scope and content, reaching not only into the personal lives of citizens but into the halls of academia, the arts and sciences, labor unions and the world of professions. Indeed, investigations, blacklists, and the politics of fear they engendered victimized not only individuals but profoundly shaped the nature, development and conduct of many professions, including social work. In this regard, Schrecker argues that the period of 
McCarthyism had a deep impact on social work ideology and practice, most notably

a nearly wholesale abandonment of advocacy on behalf of clients:

Social workers at every level had abandoned the reform impulse and active political engagement that had once been an important component of their profession. As a result, when the issue of welfare returned to the nation's agenda, social workers did not enter the debate on behalf of their clients and counter the hostile stereotyping of welfare recipients. The McCarthy era purges had silenced those voices that might have raised the issues of poverty and unemployment without blaming the victim. ${ }^{48}$

Andrews and Reisch echo Schrecker's observations, concluding that McCarthyism served to suppress dissenting voices in both the profession as a whole and in schools of social work and further supplanted the profession's commitment to social justice with an intensified focus on the development of treatment technologies:

[One] impact of McCarthyism on social work can be found in the growing emphasis on the acquisition of expertise as the primary goal of social work education and practice and the concomitant omission of discussions of the ideological bases of practice...This apolitical legacy persisted well into the 1970 s, despite the growing ideological turmoil of the intervening period...By ignoring the impact of anti-communism and McCarthyism and their underlying political and ideological messages, social work's educators contributed to the growing dissonance between the profession's stated goals and the conditions practitioners experienced in their day-to-day work. ${ }^{49}$

Maurice Isserman, an historian of American communism, has astutely noted that "...the history of communism in America is bitterly contested terrain. The passions aroused by the debate over differing interpretations of that history are seldom far removed from contemporary concerns." ${ }^{50}$ Isserman's observations are particularly salient to this study, as there is a striking absence of substantive 
examination regarding the relationship of communism to the rank and file movement (and social work as a whole) by the profession's historians. This curious state of historical void is even more noticeable (and perhaps understandable) in light of the pronouncements of historiographers specializing in the American Communist movement regarding its influence in the social work profession (as represented by Glazer and Haynes above). Much of this work has reflected a particular academic school of communist studies forged in the Cold War years of the 1950s and funded by conservative foundations, notably the Fund for the Republic. ${ }^{51}$ More noted for its overt anti-Communist ideology than its methodology, this school of study has, until only recently, generally defined public and academic perceptions of American communism as a foreign, conspiratorial ideology and movement imposed upon and directed from the outside. These interpretations have created an often distorted subtext of analysis that precludes the possibility that American communists, or those outside of the party who may have associated with an activity linked to (or supported by) the party, were guided by any significant independence of thought, individual wisdom or popular support. Within this school of thought, the very language of analysis is ideological: movements and organizations are identified as "fronts," or are "dominated" by the Communist Party rather than cooperating or agreeing with particular aspects of the party or its program; individual indications of philosophical agreement are evidence of one being a "fellow traveler;" and the communist movement as a whole, including individuals and organizations even tangentially associated with it, are "Stalinist" in character and intent. ${ }^{52}$ It is perhaps not 
surprising, then, that the association made between communism and social work (most particularly the rank and file movement) by outside historians has gone largely unanswered and unexamined by the profession's own historians. In the absence of direct evidence, one can only speculate whether the fait accompli statements of social work's once dangerous alliance with communism made by influential scholars dominating the field of communist studies have served to discourage such inquiry by the profession itself. ${ }^{53}$

Indeed, the discourse of anti-communism that dominated scholarly inquiry in the post-war period was not seriously questioned until the 1980s, encompassing the period in which the most in-depth examinations of the rank and file movement were published by social work historians. Since that time, an impressive number of socalled revisionist analyses of American communism have been published, providing more balanced studies concerning the role of American communism in the labor movement, academics, the arts and the professions. ${ }^{54}$ However, this re-examination has yet to find its way in any significant form into social work. Rather, studies of the rank and file movement to date have, for the most part, skirted this central issue, concentrating inquiry on the early development of the movement, omitting the critical period after in which charges of Communist Party domination beset the labor unions representing social workers, culminating in their final destruction in the late 1940 s and early 1950 s.

The contentious issues surrounding the question of communist influence in the rank and file movement are also inextricably tied to the phenomenon of 
unionization among white collar workers. During the critical period of the 1930 s and 1940s, the identification of professionals with the causes of the industrial union movement - job security, workplace democracy and politically informed class consciousness - drew them in unprecedented numbers into the organizations of that movement. Social workers were no exception to this historical alliance. With the possible exception of teachers, perhaps no profession was as prominent in the union movement as were social workers. Particularly concentrated in unions such as the United Public Workers of America (UPW) and the United Office and Professional Workers of America (UOPWA) that most explicitly allied themselves with the progressive politics of the times (e.g., civil rights and anti-fascist movements) and which were most identified with the Communist Party, rank and file social workers would find their leaders and their unions among the first victims of the antiCommunist backlash. In this regard, the important explication of this phenomenon has not only been noticeably ignored by the profession's historians, but by labor historians as well. As Steve Rosswurm notes in his research on unions expelled for alleged communist domination by the Congress of Industrial Organizations (CIO):

What remains on the research agenda? Virtually everything, since we [labor historians] know so little about these [left-led] unions...We especially need studies of the UPW and the UOPWA, two unions that organized large numbers of women and whitecollar workers...Most labor historians of the CIO period concentrate on the industrial proletariat...to the exclusion of the majority of working people in this country...perhaps the greatest tragedy of the expulsions was the role they played in the CIO's missed opportunity, produced by a conjuncture of the ideological and the material, to organize those who performed mental labor... ${ }^{55}$ 


\section{TOWARDS A REVISIONIST HISTORY}

In examining the historical narrative of social work to date, relatively little substantive analysis has been conducted concerning the rise and fall of the rank and file movement and the fuller meaning and contribution of that movement to the profession. The paucity of this analysis is striking given the dramatic social, economic and social crises within the profession and the nation that gave rise to its development, maturation and subsequent destruction. It is the thesis of this study that, in fact, an understanding of the rank and file movement is central to a modern understanding of our profession. For the existence of the movement both materially and symbolically embodies the complex and contradictory nexus of the dynamics of change engendered by political and social crises. The origin, development and demise of the rank and file movement reflects more than the historical curiosity of a momentary tendency in the evolution of a profession; rather, it reveals the enduring legacy of individuals, organizations and collective intellectual discourse in common struggle for the possibilities of a more just and democratic social order. And, perhaps unlike any other profession, the domain of social work is historically one uniquely born of this struggle, encompassing the self-imposed imperatives and paradoxes of morality, socially purposive service and scientific rationality.

Consequently, this study seeks to inform the terms of this enduring legacy within the dynamic world of social work. It shall attempt to do so by: 1) locating the history of the rank and file movement within the context of an evolving profession; 2) analyzing this specific history of a profession within the context of broader social 
and political forces that defined both the limits and potentials of that evolution; and

3) assessing the implications of this history for social work in terms of its past, present and future.

Such an examination does not occur in the abstract - history is composed not of the disembodied laws of a transcendent nature or a theoretical science but in the material experiences and actions of human beings seeking a collective sense of social responsibility. For both the actors of history and the narrators of history, the meaning of these individual and collective experiences is essentially, one of opportunity, choice and interpretation. In this respect, the observations of Bertha Reynolds are most apropos:

Inevitably our choices are conditioned not only by the time and location of our birth but by our position in organized society. How we get on in the struggle for survival tends to channel our choice of relationships to people in the same general situation. Life looks different from the windows of a palace or the doorway of a field laborer's shack, from one or the other side of a color line, or a collective-bargaining table. Obvious as that seems, it is nonetheless true that many people do no know that they stand in any particular place in society, and so they judge their viewpoint to be the only one possible for anybody. I believe it is indispensable to a sound relatedness to others to know where one is to start with, for what biases and blind spots to make allowance, and to know that there exist other and quite different viewpoints. ${ }^{56}$

In this regard, three primary sources of information were analyzed to reconstruct this history of the rank and file movement: 1) primary documents, consisting of union records and publications, books and articles published during the period under study, personal papers retained by key participants in the movement, and published autobiographical accounts of individuals active in the movement; 2) 
personal reminiscences of the movement obtained by the author through correspondence and interviews with movement participants; and 3) review and incorporation of secondary sources, including previous studies and books pertaining to the subject and the period under examination. While all three of these methods serve to provide a sound basis for the triangulation of data sources in order to increase confidence in the accuracy of representation, they also share unavoidable weaknesses.

These weaknesses are most notable in the inability to fully document the period and movement under study. Documentary records of the rank and file unions are fragmentary at best. Complete official records of the early unions of the rank and file are non-existent. Such documentation that is available consists of fragmentary records and publications retained by individuals or in collections of archives and libraries. Records of the later CIO unions that represented social workers are also fragmentary. Most of these records were purged by the AFL-CIO following the expulsions of these unions in 1948, and only partial records of union proceedings and publications are available in various libraries or collections of personal papers. This author attempted to review or gather all such documents that could be identified, supplementing these documents with related publications of the period and personal recollections of participants in the rank and file and its unions.

Not unlike published records, the recollections of participants who were active in the rank and file movement and its unions are also subject to their fragmentary nature. The elusive and sometimes distorted nature of human memory 
always poses issues of accuracy. In this regard, specific statements of fact or historical event were triangulated with other data sources to provide verification. The actual selection of participants for interviews was limited by the number of persons still alive, in reasonable enough health to participate in interviews and who granted permission for the author to interview and cite them. In respect to selection, the author employed a snowball process in which persons located by the author suggested other persons that could be interviewed. This process was continued until all suggestions had been exhausted. Obviously, the vagaries of time, mortality and the selection process employed also compromise representativeness. However, the author was able to locate a surprising number of key actors in the rank and file movement and its unions, thus providing a strong case for the inclusion of their remembrances in this study to provide both context and substantive information. Further detail on the methods employed in this study is located in the Appendix.

In sum, the history presented in this study, like any other, reflects the inevitable convergence of differing choices, viewpoints and interpretations. As such, the contradictory terms of such convergence cannot be overlooked, and this author takes full responsibility for the ultimate choices and interpretations employed in this narrative. 


\section{Notes to Chapter 1}

1. Remarks of Roger Baldwin at the 1918 National Conference of Charities and Corrections. See: Proceedings of the National Conference of Charities and Corrections (Chicago: University of Chicago Press, 1918), p. 397. Baldwin was director of the National Civil Liberties Bureau, later reorganized in 1920 as the American Civil Liberties Union (ACLU).

There is a certain irony to the selection of Baldwin's comments to begin this study. An avowed anarchist, Baldwin would be one of a number of early advocates of radical social work trade unionism. His outspoken support for the civil rights of radicals and communists endeared him to the movement in its early years and he provided important support, consultation and advice in the initial development of the unions. However, Baldwin himself would eventually contribute to the atmosphere of anti-Communist hysteria that hastened the destruction of the rank and file movement in social work. By 1940, Baldwin had become a staunch anti-Communist and played a central role as Executive Director of the ACLU in the development of a policy excluding members of the Communist Party from the ACLU's Board of Directors. According to Corliss Lamont, Baldwin was instrumental in the subsequent "trial" and expulsion of Board member Elizabeth Gurley Flynn, an open Communist and member of the party's National Committee. While not present at the meeting in which Flynn was expelled, Mary van Kleeck, an ACLU board member and a major leader of the rank and file movement, strongly opposed the decision (see Corliss Lamont, The trial of Elizabeth Gurley Brown by the American Civil Liberties Union (New York: Horizon Press, 1968), pp. 11-30).

2. Fisher, The rank and file movement in social work. See Note \#2 in the Preface for further detail.

3. The Communist International (commonly referred to as the "Comintern") was an international organization of communist parties formed in 1919 by Lenin and the Soviet Communist Party to coordinate the world communist movement, with a primary emphasis on the defense of the Soviet Union. Comintern decisions on policy and programs were generally binding on member parties. The American Communist Party was heavily dependent on Comintern guidance of party policy and practice, particularly in its early development. See: Theodore Draper, The roots of American communism (New York: Viking Press, 1957), and Harvey Klehr, John E. Haynes, \& Friorikh I. Firsov, The secret world of American communism (New Haven, CT: Yale University Press, 1995). An official history of the Comintern and its post-war successor, the Cominform, can be found in: Institute of Marxism-Leninism, Outline history of the Communist International (Moscow: Progress Publishers, 1971). A more critical history is provided in F. 
Claudin, The communist movement: From Comintern to Cominform, Part $1 \& 2$ (New York: Monthly Review Press, 1975).

4. C. Wright Mills, The sociological imagination (New York: Oxford University Press, 1967), p. 154.

5. Clark Chambers, Seedtime of Reform (Westport, CT: Greenwood Press, 1963).

6. Clark Chambers, Paul U. Kellogg and the Survey (Minneapolis: University of Minnesota Press, 1971).

7. June Axinn and Herman Levine, Social welfare: A history of the American response to need (New York: Longman, 1997).

8. Harry Lurie, $A$ heritage affirmed (New York: Jewish Publication Society of America, 1961). It is possible that Lurie's lapse of historical memory may reflect his gradual turn from the movement as it was linked to communism, culminating towards the end of his career in a general retreat from advocating broad social change to an emphasis on focused community organization.

9. Walter I. Trattner, From poor law to welfare state (New York: The Free Press, 1999), pp. 286-287.

10. Bruce S. Jansson, The reluctant welfare state. American social welfare policies: Past, present, and future (New York: Brooks/Cole Publishing, 1997), p. 192.

11. Barbara L. Simon, The empowerment tradition in American social work: $A$ history (New York: Columbia University Press, 1994), pp. 102-103.

In putting forth her conclusions regarding the demise of the movement, Simon cites Leslie Leighninger's Social work: Search for identity), pp. 67-68.

However, Leighninger makes no such references to the passage of the Social Security Act or the absence of major political party support of social work demands as the reasons for the decline of the rank and file movement. Leighninger does put forth several reasons for the collapse of the movement's influence within the profession, including the movement's general support of "pro-Russian" political policies, and its preoccupation with union concerns versus activity within the professional organizations (p. 105).

12. John H. Ehrenreich, J. H., The altruistic imagination (Ithaca, NY: Cornell University Press, 1985), pp. 110-121. 
13. Ibid., pp. 120-121.

\section{Ibid.}

15. Stanley Wenocur and Martin Reisch, From charity to enterprise: The development of American social work in a market economy (Chicago: University of Illinois Press, 1989).

16. Ibid., p. 182. This is not the first attempt to define the function of social work within capitalism using a political-economic framework. For example, see: Jeffrey Galper, The politics of social services (Englewood Cliffs, NJ: Prentice Hall, 1975); Robert Bailey and Michael Brake (Eds.), Radical social work (New York: Pantheon, 1976); Paul Corrigan and Peter Leonard, Social work practice under capitalism: A Marxist approach (London: MacMillan Press, 1978); Pat Walker (Ed.), Between labor and capital (Boston: South End Press 1979); and Chris Jones, State social work and the working class (Boston: Routledge \& Kegan Paul, 1983).

17. While Wenocur and Reisch's account is the most detailed one to be found within general social work history texts, their theoretical framework seriously constrains the depth of analysis regarding the movement. This is particularly noticeable in their discussion concerning the demise of the movement. Framing the differences between the rank and file and the mainstream profession as primarily a reflection of the struggle for the control of the "social work commodity," the authors explain the demise of the movement largely in terms of internal structural impediments in the process of unionization. Specifically, they cite the structure of union federation rules which inhibited the development of a social work specific "identity" within the unions and which separated unions representing public and private agency workers (pp. 204- 205). While such impediments were a factor in the demise of the movement, the evidence is clear that the bulk of the rank and file leadership were, by 1937, opposed to the craft union approach implied by Wenocur and Reisch's assertion regarding the need for a distinct social work identity in the unions. In fact, rank and file social workers in both public and private agencies stressed the need to develop unions of an "industrial" character, emphasizing the mutual interests of a broad based membership including social workers, clerical workers, maintenance workers, and other employee classifications. The eventual collapse of the movement, while certainly affected by the structural characteristics of its unions, had less to do with that structure than with larger economic and political forces exerted within and outside the profession.

18. This continued dualistic dilemma in social work has carried various labels throughout the life of the profession. Mary Richmond talked of the "retail" and "wholesale" functions of early social work. Porter Lee later distinguished "cause" and "function" roles of social work, arguing that the function side of social work was more appropriate for a fledgling profession's credibility. In the 1960s, William Schwarz discussed the need to differentiate between "social 
advocacy" and "social effectiveness." More recently, Specht and Courtney have framed this debate in terms of "social work" versus "psychotherapy." See: P. Nelson Reid and Philip R. Popple (Eds.), The moral purposes of social work (Chicago: Nelson-Hall, 1992); and Harry Specht and Mark Courtney, Unfaithful angels. How social work has abandoned its mission (New York: The Free Press, 1994).

19. Leslie Leighninger and Robert Knickmeyer, "The rank and file movement in social work: The relevance of radical social work traditions to modern social work practice," Journal of Sociology and Social Welfare 4(2) (1976), pp. 166177.

20. Ibid., p. 175.

21. Ibid., p. 176.

22. Leslie B. Alexander and Phillip Lichtenberg, P. (1978). "The "Case Work Notebook': An analysis of its contents," Journal of Sociology and Social Welfare 5(1) (1978), pp. 55-66.

23. Ibid., p. 66. The "Casework Notebook" was a monthly series in the movement's journal, Social Work Today, in which practice approaches were presented and debated. According to Jacob Fisher, this series was initiated by the journal's editors in order to assist the development of basic social work skills by the many uncredentialed and untrained relief workers that provided public services. Given this history, it is perhaps not surprising that analysis of the articles would indicate a limited overt political content (interview by author with Jacob Fisher, February 12, 1981).

24. David Wagner, "Collective mobility and fragmentation: A model of social work history," Journal of Sociology and Social Welfare 13 (1986), pp. 657-700.

25. The Popular Front policy of the Communist Party arose from the deliberations of the Communist International in the $1930 \mathrm{~s}$ as it formulated strategies to defend the U.S.S.R. from German aggression and promote a broad international anti-fascist coalition between communist parties and liberal and social-democratic organizations and forces (See Georgi Dimitroff, The united front (New York: International Publishers, 1938). In the United States, the Popular Front strategy adopted by the Communist Party directed party members and affiliated organizations to temper their criticisms of the Roosevelt administration and form alliances with progressive organizations. For fuller explanations of the Popular Front strategy, see: Lawrence Lader, Power on the left (New York: W. W. Norton, 1979); Harvey Klehr, The heyday of American communism (New York: Basic Books, 1984); and William Z. Foster, History of the Communist Party of the United States.

26. Wagner, "Collective mobility and fragmentation," JSSW, pp. 677, 679. While this author disagrees with Wagner's conclusions regarding the reasons for the demise of the rank and file movement, his analytic model regarding the 
conservative nature of professionalism holds merit for further scholarly examination.

27. Norma K. Phillips and Herbert H. Lehman, R. H., "Ideology and opportunity in social work during the New Deal years," Journal of Sociology and Social Welfare 12 (1985), pp. 251-273.

28. Ibid., p. 264.

29. Leighninger, Social work: Search for identity.

30. Ibid., pp. 61-62, 212-219.

31. Ibid., p. 68 .

32. Rick Spano, The rank and file movement in social work (Washington, D.C.: University Press of America, 1982).

33. Ibid., pp. 261-262.

34. Thomas L. Olson, Unfinished business: American social work in pursuit of reform, community, and world peace, 1939-1950 (unpublished dissertation, University of Minnesota, 1972).

35. Ibid., pp. vi, vii.

36. Ibid., p. 23. Olson's conclusions regarding the essentially negligible differences between the rank and file movement and the mainstream of the profession are quite remarkable given the historical evidence; as a consequence, his conclusions do not objectively differ from the judgements of mainstream histories of the profession.

37. Howard J. Karger (Ed.), Social workers and labor unions (New York: Greenwood Press, 1988).

38. Ibid., p. 23.

39. Shulamith L. A. Straussner and Norma K. Phillips, "The relationship between social work and labor unions: A history of strife and cooperation," Journal of Sociology and Social Welfare 15(1) (1988), pp. 105-118.

40. Ibid., pp. 112-113. This bifurcation is quite remarkable, given that the central force behind social work unionization in the 1930s was the work of rank and file activists. While it is true that the first social work union, the Association of 
Federation Social Workers (AFSW), formed in 1926, pre-dated the development of the rank and file movement, it was rank and file leaders who in 1935 organized the first national coordinating body for social work "protective associations," the National Coordinating Committee of Social Service Employee Groups (NCC)). These protective organizations (the term then applied to the early unions), with the exception of the AFSW, can directly trace their roots to the early social work "Discussion Clubs" that were formed by rank and file leaders and advocates (Jacob Fisher, The response of social work to the Depression (Boston: G. K. Hall, 1980), pp. 102-118).

41. Leslie B. Alexander, Organizing the professional social worker: The union movement in voluntary social work: 1930 - 1950 (Unpublished dissertation, Bryn Mawr, 1977). While this study is an important and seminal examination of the rank and file movement, as Alexander notes, the bulk of the primary source materials used in the study related to New York City Local 19 of the Social Service Employees Union, and thus are most reflective of this particular union local (p. 13).

42. Ibid., pp. 204-205.

43. Fisher, The response of social work to the Depression.

44. In this regard, Jacob Fisher suggests that the impact of McCarthyism on the country as a whole and social work in particular may account for this gap in the profession's historical record. A leader in the early years of the rank and file movement, Fisher later became the subject of investigations during the 1950s into Communist infiltration of the Social Security Administration. By that time, Fisher had rejected and left the Communist Party. Notably, Fisher specifically advised this author to avoid examination of the role of the Communist Party in the rank and file movement, stating that "...the evil of the past is still with us and we can ill afford the consequences of continued association" (interview by author February 12,1981 ). In a similar but less pointed vein, Fisher also downplayed the issue of communism in communications with John Earl Haynes, stating that "....any effort to trace 'CP influence' on Social Work Today, the SSEU, etc. is an exercise in academic futility" (quoted in Leighninger, Organizing the professional social worker, p. 210).

45. Ibid., pp. 237-241. Quote from p. 241.

46. Nathan Glazer, The social basis of American communism (New York: Harcourt, Brace and World, 1961), p. 143. 
47. John Earl Haynes, "The 'rank and file movement' in private social work," Labor History 16 (Winter, 1975), p. 98.

48. Ellen Schrecker, Many are the crimes: McCarthyism in America (New York: Little, Brown \& Company, 1998), p. 386.

49. Janice Andrews and Martin Reisch, "Social work and Anti-Communism: A historical analysis of the McCarthy period, "Journal of Progressive Human Services, 8(2) (1997), p. 42. For a related discussion of the impact of McCarthyism on group work in social work, see Janice Andrews and Martin Reisch, "The legacy of McCarthyism on social group work: An historical analysis," Journal of Sociology and Social Welfare 24(3) (1997), pp. 211-235.

50. Maurice Isserman, Which side were you on? The American Communist Party during the Second World War (New York: Basic Books, 1987), p. vii.

51. The Fund for the Republic sponsored an influential series of books studying Communist influence in America. The Communism in American Life series established the evidentiary and ideological bases of subsequent academic antiCommunist inquiry. Among the series more notable publications were Theodore Draper's two volumes, The roots of American communism and American communism and Soviet Russia (New York: Viking Press, 1960); Nathan Glazer's The social basis of American communism ; and Frank Meyer's The moulding of Communists: The training of the communist cadre (New York: Harcourt, Brace and Co., 1961). Other books which adopt this line of analysis include Irving Howe and Lewis Coser, The American Communist Party (Boston: Beacon Press, 1957), Max Kampelman's The Communist Party and the C.I.O. (New York: Praeger, 1957), and Harvey Klehr, The heyday of American communism.

52. In this regard, see Maurice Isserman, "Three generations: Historians view American communism," Labor History 26 (1985). While strongly supporting the "revisionist" school, this author acknowledges that the Soviet Union did in fact hold strong sway over the decisions of the national leaders of the American Communist Party; however, that the degree of hegemony held by the Soviet Union over the national party leadership continued down through the rank and file of the party is highly debatable.

The marked degree of Soviet influence on the American party leadership has been further evidenced in documents obtained in the recent opening of archives of the former Soviet Union (see Harvey Klehr, John Earl Haynes and Fridrich I. Firsov, The secret world of American communism and Harvey Klehr, John Earl Haynes and Kyrill M. Anderson, The Soviet world of American communism (New Haven: Yale University Press, 1998). Interestingly, these authors have 
used the occasion of the opening of these archives to virtually dismiss the revisionist school and its alternative analyses (see Klehr, Haynes \& Kirsov, The secret world of American communism, pp. 17-19).

53. See note 43 above.

54. For example, see: Maurice Isserman's Which side were you on?, and If I had a hammer...The death of the old left and the birth of the new left (New York: Basic Books, 1987); Mark Naison, Communists in Harlem during the Depression (New York: Grove Press, 1983); Ellen Schrecker's No ivory tower: McCarthyism and the universities (New York: Oxford University Press, 1986) and Many are the Crimes; and Steve Rosswurm (Ed.), The CIO's left-led unions (New Brunswick, NJ: Rutgers University Press, 1992).

55. Steve Rosswurm, The CIO's left-led unions, p. xv.

56. Bertha Reynolds, An uncharted journey, p. 315. 


\section{CHAPTER 2:}

\section{BEFORE THE STORM}

In 1929 there was every reason to believe that our young profession was going to move forward to an honored place in the national life. Professional education was no longer seriously in question, skills for helping people in trouble had been demonstrated, new psychological techniques contributed by another profession had begun to be sought eagerly by hospitals and clinics, courts, and counseling agencies. Social casework would come into its own, not solely to aid society's misfits, but to make sure that children would grow up to be mentally healthy and talented people would be freed to make their contribution to the common life. We were climbing to the top of the world in 1929.'

(Bertha Reynolds)

As the decade of the 1920 s was coming to a close, the young profession of social work was in the final stages of a process of fundamental transformation. The reform ethos of the Progressive Era, best romanticized in the settlement house movement, had been rapidly crumbling. In its place a new fascination with psychiatric casework technique had begun to take hold. In the illusory economic prosperity of the 1920 s it is perhaps not surprising that the potentials of human adjustment to be found in the mental world of the individual were more alluring to social workers than the vagaries of social reform efforts or the familiar, more routinized functions called for in charity work. Furthermore, social casework "...from the psychiatric point of view" seemed more in keeping with the definition of a profession than the unscientific moral do-gooder image that had dogged social work from its inception. ${ }^{2}$ 
By 1929 , the professionalization of social work had, in the eyes of its leaders, finally shed the do-gooder image, replacing in its stead a new representation of rational thought, scientifically-based technique, and a more circumspect sense of moral inspiration. The apparent triumph of professional form and function was celebrated that year in San Francisco at the annual National Conference of Social Work (NCSW). Porter Lee, president of the NCSW and director of the New York School of Social Work, greeted delegates in his presidential address with the pronouncement of this long awaited fait accompli. Social work, Lee declared, had largely rid itself from the burdens of social reform leadership and the unscientific zealotry that accompanied reform. According to Lee, social work had accomplished the necessary shift from leading the cause of social reform to providing a professional function, the efficient management and administration of social programs:

In the last analysis I am not sure that the greatest service of social work as a cause is contributed through those whose genius is to light and hand on the torch. I am inclined to think that in the capacity of the social worker, whatever his rank, to administer a routine functional responsibility in the spirit of the servant in a cause lies the explanation of the great service of social work. This capacity is perhaps a higher qualification for leadership than the ability to sway groups of men. ${ }^{3}$

For Lee and a new generation of social workers seeking to overcome the shibboleths of moral crusading represented by earlier social reformers, the new language of professional social work included "efficiency," "qualified personnel," and "measurement of results."4 
The new rhetoric of the emergent profession had, indeed, considerable substance undergirding it. In the same year that Lee elevated function over cause, the U.S. Census Bureau announced that in its upcoming national census, social work would at last be listed as a professional occupation. Official government recognition as a profession was a long-awaited sign of social work's growing power and public legitimacy. ${ }^{5}$ Indeed, while still relatively small in comparison to other professions, the ranks of social work were growing. By mid-decade, one survey estimated that some 25,000 women and men, primarily located in urban centers of the east and midwest, were employed in paid social work. By the 1930 census, the total number of paid social workers was estimated at over 31,000 , with an additional 15,000 in related fields of charity and correctional institutions. ${ }^{6}$

Recognition by the Census Bureau also reflected the development within the field of specialized training programs and the granting of advanced credentials now becoming requisite for professional standing. From the founding in 1898 of the first professional social work training program, the New York School of Social Philanthropy, over 40 professional schools had been established throughout the country. Of these, the majority had been organized after 1915 and were members of the American Association of Schools of Social Work (AASSW). While not yet a formal accreditation body in the modern sense, the AASSW would help spur the professionalization of social work through its requirements that members schools be affiliated with universities. Despite the initial lack of standardized criteria from the AASSW regarding specific coursework and degree requirements, most schools 
placed a heavy emphasis on the development of casework technique coupled with field experience. ${ }^{7}$

Within the profession, a new organization, the American Association of Social Workers (AASW), was formed in 1921 with the pronounced intention of establishing national standards of professional training and practice. While the profession had an embarrassment of riches in its number of specialized organizations, the AASW was intended to be an overarching national professional association. ${ }^{8}$ A central focus of the AASW's initial organizing efforts was the establishment of minimum membership criteria regarding experience and education. In 1922, the AASW required a minimum of four years experience in social welfare service and some educational training vaguely defined as indicative of success in social work. In July 1929 , the AASW adopted new standards for membership to take effect in 1933. The new standards established a heightened expectation of professional training and experience in social work. Membership requirements now called for a minimum of two years of college and five years of social work experience and/or other educational and training experiences. Significantly, the new standards clearly privileged training obtained in professional schools of social work. The stiffened membership requirements and the emphasis on advanced training from approved schools of social work, while bulwarking the field's evidence of professionalism, would soon prove to be a major source of contention between the mainstream profession and the bulk of uncredentialed relief workers that came to form the nucleus of the rank and file movement. ${ }^{9}$ 
The hegemony of function over the cause of social reform would further express itself in the declarations of the 1929 Milford Conference. ${ }^{10}$ Established in 1923 , the conference met annually, bringing together leading social workers in a contentious process of defining social casework. The task of the conference was critical to the consolidation of a core professional identity and definition. The proliferation of specialized fields of practice and accompanying distinct bases of knowledge and skills seriously threatened a unified sense of a profession and the fruition of the AASW's attempts to forge a national, overarching professional association. In addition, the pervasive influence of psychiatric social work technique had heightened old rivalries and insecurities in the specialized fields - would one form of social casework predominate? If so, would it be psychiatric casework?

Bertha Reynolds, a prominent adherent of the psychiatric viewpoint in the 1920 s, recalls in her memoirs the essence of the debate:

Did psychiatric social work add just another specialty to the list? Did it introduce further division among social workers who were just beginning to find themselves in relation to each other? The answers are yes and no.

Psychiatric social work did introduce a division of which I had begun to be conscious when I joined the staff of the Smith College School - a division which neither the School nor I considered desirable. However, the very rapidity of the spread of 'the psychiatric point of view' among social workers made it possible to say by 1927 ...that even if psychiatric social work was considered a specialty...it was, nevertheless, in the content of its knowledge the common property of all forms of good social casework. ${ }^{11}$ 
The final report of the Milford Conference reflected the masterful compromises necessarily made by social work's leaders to forge a common theoretical ground and justification for the profession's unified knowledge base. While deftly avoiding a specific definition of social casework, the report established the existence of a generic social case work which cut across social work's practice specialties, including psychiatric casework. The report affirmed that this generic approach was based, although admittedly unevenly, on scientific principles befitting a profession. As such, the differences observed within specialized fields of practice became incidental to the common theory base and techniques of a generic social casework used by all social workers. Perhaps most significant, the Milford Conference report affirmed the primary function of social work in the context of facilitating individual adjustment to the realities of the social world. The concept of social reform as a social work function was severely circumscribed, now redefined within the domain of the individual client's adjustment and the social worker's abilities to use their knowledge of the environment to bring available resources to bear upon the client's singular misery. As the conference report declared, "In conclusion, we find the significant movement in the decade of $1920-1930$, to be the emergence of a common casework field in which the individual, his adjustment and development, is accepted as the essential problem."12

\section{Social Work and the Liberal Tradition}

The seeming rejection of social reform by the profession was, in essence, much less abandonment than a measured turning of the cheek. As a whole, social 
work has always been inextricably bound within the ideological tenets of American liberalism, and the development of the profession in the 1920s faithfully reflected this allegiance. The notions of scientific rationality and efficiency embraced by the profession (and its concomitant disillusionment with the primacy of social reform) in fact mirrored the evolution of liberal thought before and just after World War I. After all, the reform movements of the Progressive Era arose not from a rejection of capitalism but from a zeal and idealism seeking to tame its more savage features. The anti-monopoly and civic reform movements that characterized Progressivism and the reform wing of social work railed against the excesses of capitalism, not its basic nature. To the intellectual barons of liberalism, such as Herbert Croly, John Dewey, Edmund Wilson and Malcolm Cowley, unbridled American capitalism represented outdated and distorted characteristics of individualism and competition that bred unnecessary class and social conflict, threatening a new emerging social order. ${ }^{13}$ This new order called for a capitalism reinvigorated with a more humane and disciplined character - a character which recognized and nurtured the collective mutuality of interest between worker and industrialist, farmer and manufacturer and citizen and government. In sum, the tremendous changes in industry, technology, labor-capital relations and urban life wrought by nineteenth century capitalism required new processes of social planning and control based on efficiency, expertism and an altruistic community of citizenship. Planned progress marked by virtue and evolutionary optimism, not revolution or unregulated corporate monopoly, would be the new hallmark of the twentieth century America. 
The ethos of Progressivism was a rich nutrient for the emerging discipline of social work and deeply influenced the philosophies and practice of both the established charity organization societies (COS) and the growing settlement house movement. While both wings of social work shared adherence to a liberal ideology, the expressions of their commitment would diverge in some distinctive ways - and each would shape the character of a post-war social work. The pre-war spirit of reform was best symbolized in the public eye by the work of the settlement houses and the nearly canonized status of Jane Addams. Social workers, particularly those identified with the settlement movement, were prominent leaders in the progressive crusades for mother's pensions, child labor laws, public sanitation regulation, and wage and hour labor reform. Unlike the more professionally distant caseworkers of the charity societies, settlement workers appeared to be of the community they served. Primarily based within the neighborhoods of urban poverty, settlement workers articulated the need for not only the spiritual and cultural adjustment of the individual to society but for institutionally based reforms which would alter environmental contributions to individual dysfunction. But the vast majority of the leadership in the settlement movement were not products of the communities they served. While temporarily sharing a common geography, they were profoundly separated from their clients by virtue of class, educational attainment and social privilege. As a group, the reformists within the settlement house movement sought to ameliorate social and class conflict, and did not seek to fundamentally alter class structure. $^{14}$ 
Just as the settlement house movement expressed the outward reform impulses of liberalism, the charity organization societies better exemplified liberalism's inner faith in rational scientific thought and expertise in administration. While not eschewing social reform, the leaders of the charity organizations privileged the virtues of bureaucratic efficiency and a scientifically-based method. For Mary Richmond, leading spokesperson of the COS movement, the ascendancy of a distinct knowledge base and technique was critical to the development of the profession in order to distinguish it from the unbridled passion of reformers apt to be “...bowled over by the first labor leader, or anarchist, or socialist, or whatever he happens to be in that neighborhood."15 Richmond briefly came to represent the predominant tendency within social work seeking to focus the profession's attention on the science of individual adjustment and the means to that adjustment: social diagnosis via the technique of social casework.

The final dominance of theories of individual adjustment over the politics of reform that would shape the character of the young profession in the ensuing decade found its fruition in the aftermath of the first World War. The optimism inherent in American liberalism was severely shaken by World War I, and the reverberations of disillusionment that followed dampened the zeal of its reformist wing. The Wilsonian ideals of democracy that led liberals into the war seemed irrevocably stained in the carnage that ensued and the moral blight that characterized the Versailles Treaty. Coupled with the reemergence of a seemingly unified corporate monopoly and a government sponsored campaign to destroy alleged alien-inspired 
radicalism, the resulting sense of betrayal and confusion unraveled the progressive coalition. While reform efforts would not totally collapse in the war's aftermath, Progressivism as a potent political movement had ceased to exist. ${ }^{16}$

The general splintering of progressive thought and movement was echoed in the reformist wing of social work. The tentative connections that had been made before the war with organized labor and the Socialist Party, always a source of contention with the profession's financial benefactors, now seemed ill advised. As a red scare swept the nation, reformist social workers found their patriotism and legitimacy as public servants severely questioned. Prominent social workers such as Jane Addams, Roger Baldwin and Vida Scudder found themselves under attack from both within and outside the profession. Addams, Baldwin and Scudder had been opponents of American involvement in World War I and, unlike most social workers, continued to express their pacifist sentiments during and after the war. ${ }^{17}$ In addition to her pacifism, Scudder had exhibited the temerity to openly endorse the more radical wings of labor, including the Industrial Workers of the World's 1912 textile strike in Lawrence, Kansas. Jane Addams' heresy of pacifism was nearly eclipsed by her denouncement of the Palmer Raids and outspoken support for the rights of aliens. ${ }^{18}$

Pacifism and suspect associations with unions, anarchists and Socialists earned many social work reformists, particularly within the settlement house movement, the focused attention of the press and government anti-radical investigations. The most sensational attacks would come in New York state, where 
the legislature's Lusk Committee included the settlements in their far-flung net investigating sedition. During a year long investigation that included social welfare agencies, unions, foreign language associations and reform organizations, the committee found the specter of subversion in nearly every liberal and radical organization or cause it examined. From so-called "revolutionary" unions such as the International Ladies' Garment Worker's Union and the Amalgamated Clothing Workers to the "subversive propaganda" spread by the American Civil Liberties Union, the Lusk Committee catalogued the threat of Bolshevist propaganda and subversion. ${ }^{19}$ Settlement houses, determined the Lusk Committee, had placed “...radical and revolutionary ideas on a parity with the ideals of American Government. ${ }^{, 20}$ The reactionary tide, while most pronounced in the activities of the Lusk Committee, was not isolated to New York. The allegedly subversive activities of settlement workers would also come under scrutiny by the press and ambitious politicians in Boston, Pittsburgh, Chicago and other cities. ${ }^{21}$ Addams' Hull House, the symbolic home of the settlement movement, would garner special attention. As late as 1925 it would be described as a "branch of the Soviet Government" during legislative hearings on child labor laws in Illinois. ${ }^{22}$ The enmity of virulent antiCommunists towards Addams and the causes she espoused would remain unabated into the 1930s. As late as 1934, Elizabeth Dilling's classic who's who of radicalism, The Red Network, would devote nearly two full pages to Addams, considerably more space than any of the other 1,300 individuals listed would merit - an even more 
remarkable feat given that Earl Browder, leader of the American Communist Party in 1934 , was granted a mere paragraph of exposure. ${ }^{23}$

Chastened by the malaise of liberalism and the resurgence of a conservative political zeitgeist, ideological and practical differences between the settlements and the COS began to dissipate in the 1920s. The ensuing consolidation of the profession would now be based less on the ideals of reform than the more professional, and politically safe, road of technique and individual adjustment. The flirtations of some in the profession with reform, particularly its more radical fringe alliances with progressive elements of labor and the political left, had temporarily threatened to disrupt not only the canons of professionalism but a longstanding reliance on class-conscious financial benefactors. ${ }^{24}$ Indeed, following the war, the more pronounced reform tendencies in the settlement houses increasingly gave way to an emphasis on the familiar and less politically fractious activities of community recreation and education (now the basis for a more professional field of practice called social group work). Thus, the moral character-building business of the settlement movement's class origins retained its primacy. While the spirit of social reform would maintain a hallowed place in social work canon, cause would be secondary to function, judiciously circumscribed and tamed in practice. ${ }^{25}$

The ascendance of social casework over reform efforts in the wake of World War I also heralded the transformation of social casework itself. Despite the declarations of the Milford Conference that the presence of a generic casework was more significant than any specialty of technique, the psychiatric point of view would 
largely come to characterize the profession in the 1920 s. The broad strokes of a scientifically-based casework investigation outlined in Mary Richmond's Social Diagnosis in 1917 were being replaced in the mid-twenties by a more refined model of psychiatric casework. Findings its origins in the crude pre-Freudian psychiatry of the mental hygiene movement, this new model centered upon rapidly advancing principles and techniques of psychiatry, particularly as embodied within the psychoanalytic theory of Sigmund Freud. ${ }^{26}$

As the psychiatric model came to dominate the literature, so did it enter the professional training schools. Seminars and courses focused on this new science of the mind proliferated in schools of social work, and students were urged to practice this new method in their agency placements. As one student of the time recalls,

Gone were the days when persons in need applied for assistance, had the legitimacy of their need verified by a call to a former employer if unemployed, or to the dispensary if too ill to work, and confirmed by a visit to the home... We were taught to use a detailed case history outline: circumstances surrounding birth, early childhood diseases, adjustment to other children, school adjustment, and so on up through adolescence and adulthood and into the sex life of the married adults in the family. We encountered resistance. Clients, as we called our interviewees, often failed to see the relevance of our questions. ${ }^{27}$

The embrace of this new psychiatric viewpoint served a dual purpose for the incipient profession. On the one hand, the therapeutic uses of psychiatry provided for a scientifically-based method and role that differentiated the professional social worker from the unprofessional stigma of charity workers doling out relief. The psychiatric method relied on specialized theory and techniques far more 
sophisticated than the concrete tasks of investigation and relief giving, and hence worthy of much higher professional status. At the same time, the ability to focus on the inner world of the individual allowed social workers to avoid both the political and professional dangers of environmental change efforts that lacked a coherent and professional theory base. Psychoanalytic theory provided the avenue by which social work could claim a distinct body of knowledge and skill, long so elusive to an occupation almost singularly insecure in its identification as a profession. Treatment based on a scientific understanding of the complexity of the human mind not only offered new insights and answers for human problems, but it could demonstrate real contributions to healthy adjustment. This decidedly scientific approach, however, would concomitantly influence social workers to turn the focus of their attentions from one of environmental dysfunction to that of personal maladjustment. ${ }^{28}$

The privileging of a psychological focus over social reform would also serve to not only expand the profession's base of expertise but its potential clientele. Unlike class-based social problems of poverty and inadequate housing, problems of personality were universal, and the rise of a middle class offered social work a particularly potent new market. Entrée into the burgeoning middle class better suited social work's claim to professional authority and status. While the skills of relief giving were less relevant for this potential market, skills that could be employed to shore up disorganized families and resolve intrapsychic conflict were extremely appealing. Equally important, the funding necessary to implement (and legitimize) this new emphasis was forthcoming from the traditional financial benefactors of 
whom social work had historically relied upon. In the case of psychiatric social work, funding would come not only from traditional philanthropic foundations such as the Commonwealth Fund but from government and quasi-governmental sources as well. In this regard, both the Red Cross and the Veterans Bureau, dealing with the mental health problems of returning veterans, provided significant training and employment opportunities for psychiatric social workers. ${ }^{29}$

In sum, the shift to psychiatric approaches within the field reflected the new ideological and economic realities that faced social work in the 1920s. In turn, the resulting inward focus of the profession best resolved threats to its survival and at the same time seemed to assure the emergence of an unlimited market for its more refined product. But while these abstract philosophical, political and social forces provided the necessary conditions and means for the shift in social work towards the psychiatric viewpoint, they do not contain a fully satisfactory explanation for this shift. Changes in social thought reflect not merely responses of human actors to abstract structural dynamics beyond their influence or recognition but are themselves shaped by the experiences of human actors individually and collectively and the meanings placed on these experiences. As one settlement worker explained:

You have to understand that it [the failure of reform] wasn't just a political thing. For most of us [social workers] it was our failure. $W e$ had failed. Most of us didn't think like economists or philosophers - I didn't anyway - we were workers. No matter how hard we tried it didn't seem to matter. When I went to a lecture on Freud it was like a revelation. Maybe we couldn't change the world, but I could do something for somebody, and if enough of us did it... well, I don't know, but it seemed like he had 
his finger on something and I thought maybe this was it. I mean, it was wrong finally, but what else did we have? ${ }^{30}$

Jacob Fisher, a leading figure in the rank and file movement, would echo this

personal crisis many social workers felt as they sought to navigate the social and

political changes of the 1920s:

The world and the profession was adrift for awhile after the war.

We were shell-shocked, and for a younger generation the old ideas

and leaders seemed irrelevant. We needed a new road and Freud

represented it. It was more than Freud, too - people were

fascinated by personality and we weren't any different. Pathology

was much more intrinsically rewarding than poverty. ${ }^{31}$

Bertha Reynolds, a leading proponent of psychiatric social work in the 1920s,

reflects in her memoirs that the appeal psychiatric method held for social workers

was more than just a new technique for application on others. It was also a source of

apparent powerful personal transformation for the individual social worker, both as a

provider and recipient of therapy:

Counselling with students on the summer campus, on winter visits, or by mail, became a rewarding third vocation. A remark of a psychiatrist at the School...meant much to me. It was to the effect that something happened when students who had problems in learning counselled with me. They became 'like different people.' It was a sacred trust, whatever gift I had for helping people, and something I could not ignore, nor, in accepting it, fail to give it my best...

No subject was more debated among psychiatric social workers in the 1920's than the question whether a psychoanalysis was necessary for professional success. That it was an advantage was rather generally conceded, and for a period of years New York City, which was almost the only place to obtain an analysis, was overloaded with social workers whose job performance was made unpredictable by the emotional storms they were riding in their personal therapy...As the emphasis in psychiatric casework was 
more and more placed upon the dynamic effect of the relationship between workers and client; it became increasingly necessary to consider what our own unconscious conflicts might be doing to the people we were supposed to help. ${ }^{32}$

The vitiation of social reform activities within social work was part of - but substantially more than - the desires of an anthropomorphized profession to obtain elevated social status. Likewise, individual social workers were not just naive pawns in the greater manipulations of a cabalistic funding elite or the recondite workings of abstract economic forces. The gradual dominance of theories and techniques of individual adjustment also, and importantly, reflected the real individual and collective experiences of social workers - feelings of disappointment, confusion, success and hope.

\section{Dissenting Voices: Social Work, Socialism and the Labor Movement}

Not all the voices of social work in the 1920 s mirrored the profession's general retreat from reform and its enthusiasm for a more personality-focused technique of individual adjustment. A handful of social workers constituted a small but vocal left wing within the profession and sought to forge close connections between more militant wings of organized labor and elements of the Socialist and Communist parties. Some, such as Roger Baldwin and Mary van Kleeck, were early converts to the radical persuasion, while others, such as Grace Coyle, Eduard Lindeman and Harry Lurie, selectively flirted with the left while staking their faith in a core liberalism. 
Social work's early radicals found their inspiration in the populist movements of the late 1800 s, the militant organizing efforts of unions such as the ILGU and the IWW, and the reformist social critiques of utopian socialists and the more pragmatic Socialist Party. But such sympathies and alliances were hardly well organized or widespread among social workers, and rarely were acknowledged by the profession's leadership. As the red scare began in the wake of World War I, Roger Baldwin displeased many at the $1918 \mathrm{NCSW}$ with a scathing critique that maintained social work's "obedience" to capitalism rendered the profession's work "...undemocratic at heart - and the heart is its source of financial support."33 Baldwin's attacks on social work and its benefactors, his support of the Russian revolution and the IWW's anarcho-syndicalist ideals, and his imprisonment for draft resistance were far outside the profession's mainstream.

Indeed, Baldwin's largely ignored plea at the NCSW for an alliance with the still nascent labor movement reflected the historic tensions that existed between labor and social work. As leaders of the Jewish Welfare Society in Philadelphia would later tell delegates at the $1926 \mathrm{NCSW}$ conference:

The fundamental differences between the objectives of tradeunions and of social agencies is that while the case worker is interested in the individual, family, [and community] and formulated a program to meet its problems, the trade-union, on the other hand is concerned with its members at large...Socialists, and to some extent trade-unions, have tended to look upon social work with suspicion and scorn, when they were not openly hostile. ${ }^{34}$

The seeds of labor's suspicion regarding social work were sown in the early attitudes and practices of COS leaders and their workers. Concerned with the perceived baser 
moral impulses of the poor and working masses, many early social workers were convinced that moral enlightenment, not the militant tactics of labor unions for better working conditions and an eight-hour work day, were central to the improvement of society. Many early charity societies openly opposed labor's use of strikes to pressure employers, often denying relief to strikers and their families and pressuring adults on relief to take the jobs of striking workers. Some societies, such as the New York Association for Improving the Condition of the Poor, viewed organized labor in the 1870 s as a clearly anti-American movement closely aligned with "...socialistic, incendiary and revolutionary dogmas" spread by such international revolutionary organizations as the Communist International. ${ }^{35}$

As compared to the charity organization societies, the goals of organized labor and radical political movements received a more sympathetic response from the leaders of the settlement movement. The settlement movement's more pronounced emphasis on the betterment of environmental conditions for the poor and working class was considerably more well-disposed to the social and economic program of labor unions than the stricter moralism of the societies. At the peak of the Progressive movement, settlement workers often joined with labor unions in campaigns for housing laws, wage and hour regulation, legislation to improve factory conditions, and enactment of child labor laws. The attraction of many settlement workers to the Progressive Party also nourished an alliance with labor, as social workers became instrumental in the development of the party's 1912 social welfare platform, which championed the establishment of the eight-hour work day, 
federal involvement in setting factory standards and the provision of workmen's compensation and social insurance. ${ }^{36}$ Many settlement houses opened their meeting rooms for labor organizers, and some within the settlement movement, such as Florence Kelley and Jane Addams, were instrumental in the development of the National Consumers League and the Women's Trade Union League. Still others, such as Robert Hunter, Karl Borders, Vida Scudder and Ellen Starr credited their involvement with labor unions as instrumental in their conversion to socialism. ${ }^{37}$

Despite the alliances that did exist between unions and some of the settlements, significant tensions between the two camps were ever apparent. While some settlement workers, such as Borders, Scudder and Starr were decidedly partisan in their support of unions, others were as suspicious and opposed to the union movement as their counterparts in the charity organization societies. Still others, such as Jane Addams, took a more circumspect view regarding unionism. Addams' support of union goals was tempered by her concern that the elements of "class warfare" engendered by the militant demands of unions would undermine her vision of a class stratified but socially harmonious society. ${ }^{38}$ While sympathetic to the need for reform to better the conditions of working men and women, Addams feared the more militant and revolutionary wings of the labor movement, and believed settlements were called to a mediating role between the excesses of corporations and the political intrigues of the unions. Such attempts at mediation were often ill received by unions and served to maintain the suspicion within organized labor that social work was, at most, a tenuous ally. ${ }^{39}$ 
The generally distant relationship that existed between the mainstream of social work and the labor movement following the demise of the progressive movement would solidify in the increasingly conservative character of the profession after World War I, as the profession's focus on individual adjustment began to supplant its more sweeping social reform ideals. Despite the chilling effect of this turn, a small but vocal number of social workers maintained their allegiance to the cause of unions and a radical ideology. This left-wing of the profession, while relatively small in number, included both prominent social workers such as Mary Van Kleeck and Roger Baldwin, as well as a younger generation such as Harry Lurie and Karl Borders. All had been informed by the experiences of Progressivism and the politics of anarchism, the Socialist Party, and the emerging Communist Party. Still others, such as Florence Kelley, Eduard Lindeman and Lillian Wald would be inspired by the Russian revolution and subsequent trips to Russia to observe firsthand this new national experiment in socialism. ${ }^{40}$ While sharing a common dissatisfaction with the destructive aspects of American capitalism, members of this left wing in the profession represented more disparate voices of dissent than any organized program of action or well defined ideology. With the exception of Van Kleeck and Baldwin, few would publicly pose any serious critique of the profession or directly challenge the profession's leadership. Rather, in the conservative climate of the 1920s, an organized radical presence was both rare and mostly ignored by the mainstream profession's leadership. 
Despite the apparent paucity of radical thought and action within the profession during this period, two events in 1924 and 1926 would presage the later emergence of an organized and left-led threat to the profession as represented in the rank and file movement. The first challenge to the profession's political complacency would be an intellectual assault mounted by Mary van Kleeck and Roger Baldwin at the 1924 National Conference of Social Work. The second event, led by workers in the Jewish Federation Societies of New York City would be less noticed but would constitute a more far-reaching omen of events to unfold in the next decade.

Unlike Baldwin, an avowed anarchist and supporter of radical causes, Mary van Kleeck seemed an unlikely candidate for the mantle of radical leadership. ${ }^{41}$ Raised in a family dominated by her Protestant minister father, van Kleeck was an active church member in her adolescence as well as being a member of the National Society of Colonial Dames. Drawn into the reform efforts of progressivism through her church activities, van Kleeck decided upon social work as a career and enrolled in Smith College. Upon graduation in 1905, van Kleeck was employed at the College Settlement House in the lower east side of New York City. For the next five years, van Kleeck investigated the lives of factory girls and women, publishing numerous monographs that were influential in eventual passage of protective laws by the state legislature. Following completion of a well-received book investigating the conditions of women in the bookbinding trades, van Kleeck was appointed head of the Russell Sage Foundation's Committee on Women's Work (later renamed the 
Industrial Studies Division) and launched a series of investigations into the work conditions of women in factories. Van Kleeck's investigations drew her close to the ranks of organized labor and she soon became a leading proponent of workmen's compensation, unemployment insurance, and social insurance. ${ }^{42}$

Upon her appointment to the War Labor Policies Board during World War I, van Kleeck intensified her work with the labor movement, hosting a conference on the rights of trade union women in 1918. Including representatives from all the national and international labor federations that admitted female members, the conference was hailed by The New Republic for its progressive platform on the rights and needs of women workers: "The active and organized cooperation of the disciplined leaders of the American women's trade union movement is essential to the effective protection of our industrial morale from the risks that inevitably attend the unregulated incursion of women into industry. ${ }^{, 43}$ But as World War I came to an end, van Kleeck resigned from the War Policies Board to return to the Russell Sage Foundation, urging the development of a permanent federal agency responsible for protecting the rights of working women. Lobbying congressmen, van Kleeck authored legislation that was subsequently introduced and passed in 1920, establishing The Women's Bureau in the Department of Labor. ${ }^{44}$

Following the war, van Kleeck sharply veered to the political left. Inspired by the Russian Revolution and now convinced of the need for national social and economic planning, van Kleeck began a long association with the Communist Party and the radical unions of the Party's Trade Union Educational League (TUEL). 
Joining with like-minded radicals in the profession, van Kleeck brought her commitment to socialism before the 1924 National Conference of Social Work. ${ }^{45}$

Amidst the relative conservative complacency of the 1920 s, few delegates at the NCSW were kindly disposed to the presentations of van Kleeck and Roger Baldwin. Reflecting on the reform platform of the 1912 conference that had been incorporated into the Progressive Party campaign, van Kleeck and Baldwin castigated social work's retreat from progressive politics and its failure to recognize its common interests with the labor movement. Accusing social work of being blinded by the class interests of its financial benefactors, van Kleeck argued that the emerging movement of industrial unionism held the key to future political power and economic change, a change van Kleeck believed would lead to worker control of national industry and government. ${ }^{46}$ Baldwin echoed van Kleeck, claiming that the lessons of the Bolshevik revolution and the rapid growth of labor parties in Europe and Mexico demonstrated a coming new world order based on the principles of socialism. Urging social workers to join the movement to create a worker's party in the United States, Baldwin cautioned the profession that "...if social workers are to be participants in the essential struggle for larger human freedom...they can achieve it only by identification with the cause of labor., ${ }^{, 47}$ Despite their inflamed rhetoric, van Kleeck and Baldwin were clearly standing outside the mainstream beliefs of their audience. As one observer noted, “...they seemed odd rather than dangerous. There was polite applause, a mild rejoinder by Paul Kellogg, editor of the Survey...then silence. ${ }^{.48}$ 
While van Kleeck and Baldwin's admonitions to social work to recognize the growing power of labor unions went largely unnoticed by the profession's elite, in New York City social workers employed by the agencies of the Federation for the Support of Jewish Philanthropic Organizations were taking the first modest steps of turning it into an historic reality. Formal philanthropic organization within the Jewish community of New York had first appeared in 1828, when the Shearith Israel Congregation established the Hebrew Benevolent Society, an agency dedicated to providing family welfare services. ${ }^{49}$ As European Jews immigrated to the United States in increasing numbers during the nineteenth century, meeting the needs of these mostly poor newcomers led to a proliferation of volunteer relief organizations. To cope with the resulting complexities and rivalries that arose in financing and coordinating the various services provided by these charitable agencies, a centralized federation responsible for overall fundraising was established in 1918, representing some 92 programs in three city boroughs. ${ }^{50}$

Initially reliant upon untrained volunteers, by the mid 1920s Federation constituent agencies were increasingly staffed by paid professionals, including social workers. Until 1925, many of these trained charity workers had been students in the School for Jewish Communal Work. While not a professional school of social work, it offered a series of courses in social welfare, recreation, and education services. Following the school's closure in 1922, the National Jewish Conference solicited funds from various foundations and Jewish federations to establish the Graduate School for Jewish Social Work in 1925 . Through a cooperative agreement with the 
New York School of Social Work, students in the program received the general professional coursework of the New York School and specialized training in communal work through the Graduate School for Jewish Social Work. ${ }^{51}$

The growing professional make-up of Federation caseworkers and supervisors quickly brought to the surface long standing tensions regarding working conditions, caseload size and training and personnel standards. Dissatisfied with the response of Federation administrators to their concerns, caseworkers and supervisors formed the Association of Federation Social Workers (AFSW) in $1926 .{ }^{52}$ Not yet a trade union in actual form, the AFSW articulated a core series of demands giving rise to its formation:

1) Standardization of types of requirements for social workers employed in organizations under the Federation.

2) An adjustment of minimum salaries commensurate with training requirements and the increased cost of living.

3) Adjustment of increases to insure retention of experienced workers.

4) Establishment of health insurance for workers.

5) Standardization of case load compatible with doing good work in a reasonable time limit. ${ }^{53}$

Despite the AFSW's calls for improved workplace conditions, in practice it emphasized standards of professional practice and worked in a mostly cooperative manner with agency administrators:

The prime importance which has grown out of the Association of Federation Social Workers is the cooperation of trustees, executives and staffs. With this cooperation growing stronger each year, it is conceivable that social workers will not be ashamed to ask for a living wage but with standardization aimed at by the Association, will receive it without asking. ${ }^{54}$ 
While the initial organization and demands of the AFSW would not be accompanied by the more class-conscious political militancy of unions as envisioned by van Kleeck and Baldwin, the early AFSW would foreshadow a new era for social work in the face of the Great Depression. 


\section{Notes to Chapter 2}

1. Reynolds, An uncharted journey, p. 134.

2. Quote from Ibid., p. 132. With the publication in 1930 of Virginia Robinson's $A$ changing psychology in social case work (Chapel Hill: University of North Carolina Press), the psychiatric casework model seemed to have at last achieved hegemony in social work practice theory, only to be severely tested in the wake of the Great Depression.

In regard to the "do-gooder" stigma, Don Kirschner notes in The Paradox of Professionalism (New York: Greenwood Press, 1986) that among the new professions forming at the turn of the century, social work appeared the least secure in its sense of profession and devoted the most time "agonizing" over this insecurity (pp. 53-56).

3. Porter R. Lee, "Social work: Cause and function," Proceedings of the National Conference of Social Work (Chicago: University of Chicago Press, 1929) p. 20.

4. Ibid., pp. 7-20.

5. "Say 'social worker' to the census man" in The Compass (February 1930), p. 1.

6. Leighninger, Social work: Search for identity, pp. 13-16; Wenocur \& Reisch, From charity to enterprise, pp. 89-91.

7. Ibid.

8. Organizations representing specialty fields of practice included the American Association for Organizing Family Welfare (later the Family Welfare Association), the American Association of Medical Workers, the American Association of Psychiatric Social Workers, the National Probation Association, and the National Association of School Social Workers. Other national organizations included the National Federation of Settlements, the National Conference of Social Work, the International Migration Service, the National Association of Travelers Aid Societies, the Child Welfare League, and the National Committee for Mental Hygiene.

The AASW evolved out of the National Social Worker's Exchange (which had its own origins in the Social Work Division of the Intercollegiate Bureau of Occupations). In 1920 the Exchange appointed a steering committee to examine the potentials of a new professional organization of national breadth, resulting in the formation of the AASW in June of 1921. Interestingly, among the members 
of the steering committee was Mary van Kleeck, then a prominent social worker with the Russell Sage Foundation. van Kleeck would soon become a theoretical leader of the rank and file movement, assailing the very organization she was instrumental in forming. For more information on the formation of the AASW, see Leighninger, Social work: Search for identity, pp. 8-15; and Wenocur and Reisch, From charity to enterprise, pp. 119-127.

9. Leighninger, Ibid., pp. 12-13; Wenocur and Reisch, Ibid., pp. 132-134.

10. American Association of Social Workers, Social casework generic and specific: A report of the Milford Conference Studies in the Practice of Social Casework (New York: AASW, 1929).

11. Reynolds, An uncharted journey, p. 131.

12. AASW, Social casework generic and specific, p.11.

13. The voices of these and other liberal spokespersons, were extremely influential within social work circles, particularly through publications such as The New Republic and The Nation (interviews by author with Jacob Fisher, September 9 , 1980 and Abram Flaxer, August 16, 1980). Olson notes in Unfinished business that Eduard Lindeman became one of John Dewey's "most enthusiastic supporters" (p. 9). Other influential social workers such as Paul Kellogg, editor of the reform minded Survey, were equally influenced by the greater currents of American liberalism (see Chambers, Paul U. Kellogg and the Survey). For a broader view of the influence of liberalism during the Progressive Era in general and on social work in particular, see Richard Pells, Radical visions \& American dreams (New York: Harper \& Row, 1973) and Simon, The empowerment tradition in social work.

14. Wenocur and Reisch (From charity to enterprise, pp. 73-74) argue that while the leadership of the settlement house movement reflected its upper class origins, settlement house workers as a group began to reflect in increasing numbers working class men and women, infusing contradictory tendencies within the movement. According to Wenocur and Reisch, while some were drawn to settlement work as a stable occupation and hence stressed recreational and educational activities, others sought more radical social reform, creating tension between the movement and its financial backers. While the authors' definition of "radical" is vague, there is little evidence that much of the "radical" activities of settlement workers significantly tested the boundaries of liberal Progressivism.

15. Mary Richmond, quoted in Mimi Carson, Settlement Folk: Social thoughts and the American settlement movement, 1885-1930 (Chicago: University of Chicago 
Press, 1990), p. 67. In later years, Richmond would protest the extreme denial of environmental influences that some read into her work. While privileging the technique side of the social work function in her writings, Richmond acknowledged the legitimacy of social reform efforts, albeit conceptualized as more politically conservative in nature than Addams or others farther to the left (Trattner, From poor law to welfare state, p. 257).

16. The relationship of social work and Progressivism would reach its heights in the formation of the Progressive Party in 1912. Social workers such as Jane Addams, Paul Kellogg, Florence Kelley and Graham Taylor were strong supporters of the party. The Progressive Party's presidential candidate, Theodore Roosevelt, ran on a platform which substantially reflected recommendations on social insurance and industrial regulation put forth previously by a committee of reform social workers at the National Conference of Charities and Corrections. With the defeat of the Progressive Party and its subsequent demise, most social workers returned to the folds of Wilson's victorious Democratic Party. By the end of the 1920s, many of the reforms achieved by the Progressive movement had been substantially weakened. Attempts to ban child labor through the federal Child Labor Amendment were defeated when the statute was declared unconstitutional by the Supreme Court, and waning interest in state legislatures stalled or rolled back many reforms in housing, work place regulation, and social insurance (see: Chambers, Seedtime of reform; and Fisher, The response of social work to the Depression).

17. Perhaps by virtue of gender, Roger Baldwin went beyond verbal opposition to the war. Baldwin's commitment to anarchism and pacifism would lead to his conviction and imprisonment for violation of the federal selective service law.

There was a considerable pacifist sentiment within the profession at the onset of U.S. involvement in the war. For example, a rump caucus at the 1917 Pittsburgh NCSW supporting the civil rights of people opposed to the war drew over one thousand social workers. While U.S. entry into the war substantially muted these sentiments, a number of social workers such as Lillian Wald, Owen Lovejoy and Paul Kellogg were prime movers behind the activities of the American Union Against Militarism. For a retrospective analysis by Baldwin of the pacifist positions of social workers during the World War I, see Roger Baldwin, "Social workers and war: A comment," Social Work Today (February 1935), p. 28.

18. Karger, Social workers and labor unions, p. 7; Carson, Settlement folk, p. 165.

The Palmer raids, named after the U.S. Attorney General whose office initiated the raids, were a major feature of the post-war red scare. Beginning with government attacks on members of the Industrial Workers of the World and 
prosecution of pacifists opposed to the draft and the war, a wave of government sponsored political repression aimed at radicals and radical organizations spread throughout the country. Following passage of the Immigration Act of 1918, which enabled the government to deport aliens who were members of "subversive" organizations, the U.S. government staged a series of raids throughout the country rounding up thousands of radicals for possible deportation. Following the first raids of 1919, over 200 alleged radical aliens were deported (including the anarchist Emma Goldman, a not infrequent visitor at Hull House). These raids were followed up in 1920, targeting alien members and leaders of the Communist Labor Party and the Communist Party. Between $8,000-10,000$ people were rounded up, jailed and/or deported as a result of the raids (see: Foster, History of the Communist Party of the United States, pp. 174174; Howe \& Coser, The American Communist Party, pp. 50-52, and Schrecker, Many are the crimes, pp. 50-61).

19. William Gellhorn (Ed.), The states and subversion (Ithaca: Cornell University Press, 1952), pp. 232-241.

20. Quoted in Carson, Settlement folk, p. 163

21. Gellhorn, The states and subversion, pp. 232-241.

22. "branch of Soviet Government" quoted in Carson, Settlement folk, p. 167.

23. Elizabeth Dilling, The red network (Chicago: self-published, 1934), pp. 259-261.

24. Jacob Fisher, "Social work and liberalism," SWT, pp. 9-12.

25. For more general treatments of social work's retreat from social reform, particularly within the settlement house movement, see: Chambers, Seedtime of reform; Roy Lubove, The professional altruist: The emergence of social work as a career (New York: Antheum); and Judith A. Trolander, Settlement houses and the Great Depression (Detroit: Wayne University Press, 1975).

26. Trattner, From poor law to welfare state, pp. 193-214; Lubove, The professional altruist, pp. 55-117.

27. Jacob Fisher, On vanishing ground: A memoir of the twenties (Fairfax, VA: Piney Branch Press, 1979), p. 248.

28. Lubove, The professional altruist; Chambers, Seedtime of reform, pp. 95-96. 
29. Such "superstructure" explanations of social work's shift to a psychiatric approach have been well represented within the literature. For example, see Lubove, The professional altruist, pp. 55-117; Ehrenreich, The altruistic imagination, pp. 27-77; and Wenocur \& Reisch, From charity to enterprise, pp. 100-114.

30. Interview by author with Margaret Levy, September 12, 1981.

31. Interview by author with Jacob Fisher, February 12, 1981.

32. Reynolds, An uncharted journey, pp. 129, 124.

33. Roger Baldwin, Proceedings of the National Conference of Charities and Corrections, p. 397; interview by author with Herbert Aptheker, July 28, 1980.

34. J. Billikopf \& B. Glassberg, "Trade unions and the family welfare agency" in Proceedings of the NCSW (Chicago: University of Chicago Press, 1926), pp. 339-340.

35. Albert Deutsch, "American labor and social work," Science and Society, 8 (April, 1944), pp. 289-304 (quote of AICP on p. 292); Straussner \& Phillips, "The relationship between social work and labor," JSSW, pp. 105-127.

36. Chambers, Seedtime of reform, p. 88. The Progressive Party platform was almost directly adapted from a report to the 1912 National Conference of Charities and Corrections by its Committee on Standards and Living Labor. The committee, chaired by Owen Lovejoy, was composed of social workers prominent in the settlement movement and the Progressive Party. See Deutsch, "American labor and social work," Science and Society, pp. 297-298.

37. Trolander, Settlement houses and the Great Depression, pp. 20-21; Carson, Settlement folk, pp. 81-82; Gerald Rothman, Philanthropists, therapists, and activists (Cambridge: Schenkman Publishing, 1985), pp. 28-29. Borders was executive secretary of the Socialist Party's League for Industrial Democracy in Chicago, and in the 1930s formed the Chicago Workers Committee on Unemployment (Folsom, Impatient armies of the poor, pp. 341-342). Borders was a strong proponent of the growing rank and file movement in social work.

38. Addams, quoted in Carson, Settlement folk, p. 81;

39. Carson, Settlement folk, pp. 79-82; Jane Addams, "The Settlement as a factor in the labor movement," in Residents of Hull House (Eds.), Hull House maps and 
papers (New York: Thomas Y. Crowell, 1895), pp. 184-85.

40. Fisher, The response of social work to the Depression, pp. 66-69; Joel Schriver, Harry Lawrence Lurie, a rational radical: His contributions to the development of social work, 1930-1950 (unpublished dissertation, University of Iowa, 1984) pp. 73-98; Karl Borders, "Social workers and a new social order," in Proceedings of the National Conference of Social Work (Chicago: University of Chicago Press, 1933), pp. 590-607; Lewis S. Feuer, Marx and the Intellectuals (Garden City, NY: Anchor Books, 1969), pp. 100-140.

41. Indeed, in his personal remembrance of the rank and file movement, Jacob Fisher described van Kleeck as having "...the patrician carriage and speech, the imperious presence and the grande dame manner of the mistress of a nineteenthcentury salon" (Fisher, The response of social work to the Depression, p. 67).

42. Elisabeth Moore, Mary van Kleeck: A bibliographical sketch and annotated bibliography of her writings (unpublished thesis, Florida Atlantic University, 1986), pp. 4-33; Fisher, The response of social work to the Depression, p. 67-68.

43. "Women in industry," The New Republic, 17 (October 26, 1918), p. 366.

44. M. Anderson, Women at work (Minneapolis: University of Minnesota Press, 1951), pp. 112-115; J. J. Kenneally, "Women and trade unions, 1870-1920: The quandary of the reformer," Labor History, 14(1) (1973), pp. 42-55.

45. While there is no documentary evidence that van Kleeck ever joined the Communist Party, there is ample evidence that she was closely in consultation with the Party during the 1920 s -1940 s. During the 1930s and 1940s she was a frequent contributor to Party publications, consistently supported Party positions, and assisted the Party in drafting what would introduced in Congress as the 1934 Lundeen bill on unemployment insurance (Folsom, Impatient armies of the poor, p. 391). An alternative bill, the Wagner-Lewis bill was eventually passed in Congress. In an interview with this author, $\mathrm{CP}$ chair Gus Hall confirmed that van Kleeck was an active supporter and participant during the 1920s and 1930s of the work of both the Communist-led Trade Union Educational League (TUEL) and its predecessor, the Trade Union Unity League (TUEL) (November 12, 1983).

The TUEL, formed in 1920, was a radical caucus of unions within the American Federation of Labor (AFL) seeking to move the AFL toward industrial unionism. Communist Party leaders such as William Foster (TUEL chairman) and Earl Browder (editor of the TUEL's Labor Herald) were instrumental in the formation and leadership of the TUEL (see William Z. Foster, American trade unionism (New York: International Publishers, 1947); and Joseph Starobin, 
American communism in crisis, 1943-1957, pp. 52-53). The TUEL was disbanded in 1929 and reformulated as the TUUL, this time as a distinct dual union effort. Some of these early TUEL/TUUL unions would later transform themselves into the unions of the rank and file, including the International Union of Bookkeepers and Stenographers, which later became the United Office and Professional Workers of America (Harvey Levenstein, Communism, anticommunism and the CIO (Westport, CT: Greenwood Press, 1981), p. 37).

46. Mary van Kleeck, "Sources of power for industrial freedom," Proceedings of the National Conference of Social Work, Toronto, 1924 (Chicago: University of Chicago Press, 1924), pp. 370-373.

47. Roger Baldwin, "The challenge of social work to the changing control of industry," Proceedings of the National Conference of Social Work, Toronto, 1924 (Chicago: University of Chicago Press, 1924), p. 373.

48. Fisher, The response of social work to the Depression, pp. 32-33.

49. Lurie, $A$ heritage affirmed, p. 23.

50. Ibid., pp. 78-79.

51. Ibid., pp. 102-102.

52. Interview by author with Celia Katz, May 15, 1981 (Katz was a member of the AFSW in the late 1920s and a later rank and file activist).

53. Executive Committee of Association of Federation Workers of the Association of Federation Workers in New York, "The history and activities of the Association of Federation Workers in New York," The Jewish Social Service Quarterly 8 (June, 1932), p. 183.

54. Ibid., p. 184 


\section{CHAPTER 3:}

\section{INTO THE MAELSTROM}

What is involved here is a shift of power from ownership to work, including the work of the industrial workers, the farmers, the professional workers, the intellectual workers, the experts in scientific management. The shift in power from ownership to work is a shift in the fundamental principle of the organization of our society...Those of us who say "Let us have evolution and not revolution"; those who say "Don't let us go into chaos; let us just patch up the old"-those people are really supporting the old; they are swinging their support to the status quo...there must be no preaching of peace where there is no peace. It lies with the working class, with which social workers have the bond of common goals, to transform the principle of government and of industry alike from possession to creative work... ${ }^{1}$

(Mary van Kleeck, 1934)

The relatively sudden onset of the Great Depression occurred, almost ironically, at a time in which the masses of Americans appeared to be enjoying a period of unprecedented economic prosperity. Certainly for American business, it was a time of bright outlook for the future and huge profits for the present. During the decade of the 1920s, production and profit levels continued to rise and, at least for the middle and upper classes, hopes were high. On the surface it appeared that free enterprise was delivering on the promise of the good life.

Under the surface of the rosy economic illusion in which the United States of the 1920s operated, however, ominous indications of coming hardship were establishing themselves. During the 1920 s real wages fell sharply behind productivity, with workers averaging a forty-nine hour work week and a weekly take-home pay of around twenty-six dollars. Throughout the decade depressed farm prices produced an unprecedented number of bankruptcies in rural America, and 
increased mechanization in urban factories sent the unemployment rate steadily upward. While unemployment in the 1920 s had always been stubbornly high, following the stock market crash of 1929 , unemployment rates began to rise dramatically. By the spring, unemployment was estimated at nearly three million, and by the following spring of 1930 it would reach eight million. The crisis continued to deepen at an unprecedented rate; in 1933 nearly one third of the workforce, some fifteen million workers, were out of a job. ${ }^{2}$

For those poor people who had never enjoyed the prosperity of the 1920 s to begin with, to whom the day to day struggle for survival was a normalized experience, it may have merely appeared that more would join in sharing their misery. To the new poor, however, for the millions suddenly thrown into unemployment and desperate poverty, their world became a chaotic, confused nightmare. For those seeking private or public assistance, the situation in 1929 was extremely bleak. The practice of relief-giving in the United States had historically been viewed as primarily one for which responsibility lay with local communities or state governments, with little federal involvement or oversight. Furthermore, those services available to the poor and unemployed consisted of a patchwork of private charities and publicly financed institutions, wholly inadequate to deal with the millions now in need of assistance.

\section{The Unemployed Respond}

At first, reaction from the unemployed was muted and slow to take shape. Many accepted the response of government and business that the crisis was 
temporary - that self reliance was the key to recovery. President Herbert Hoover rejected calls for massive federal relief assistance, embracing the belief that relief was primarily a local responsibility. Too little too late, Hoover provided funding for a limited public works program in 1930, and established the President's Emergency Committee for Employment (PECE), an advisory committee that served to coordinate the funds and provide assistance to states and employers in developing job investment strategies. ${ }^{3}$ But limited federal intervention and the advice of PECE had little effect. As the crisis deepened, the newly unemployed found themselves immersed in a crushing poverty. Life savings were quickly used up, families were broken apart and the very essentials of food, shelter and heat were becoming scare. Slowly, as Piven and Cloward note, the poor came to see their situation in a new light:

They began to define their personal hardship not just as their own individual misfortune but as a misfortune they shared with many of their own kind. And if so many people were in the same trouble, then maybe it wasn't they who were to blame, but the 'system'...The resulting unrest of the unemployed began to manifest itself in a spontaneous and largely unorganized fashion. Incidents of individual and mass looting became increasingly commonplace. Relatively spontaneous marches, demonstrations, and even storming of relief offices occurred throughout the country. 4

In due time the unemployed began to organize their protest and resistance.

Much of this organization came with the participation and leadership of the political left, particularly the Socialist and Communist parties. Organized groups of the unemployed now devised militant and sometimes violent tactics to agitate for relief. 
Mass marches and rallies outside of city halls and relief offices became a common occurrence throughout the country, sometimes resulting in bloody confrontations between demonstrators and police ordered out to disperse the crowds. Groups of unemployed workers joined together to resist attempts of authorities to evict those who could no longer pay their rent or make mortgage payments. Riots, often the result of attempts by authorities to suppress protest rallies and marches, erupted in major cities throughout the country. In the face of growing disorder, political leaders and newspapers spoke ominously of the subversive nature of the protesters and their organizations, and of the possibilities of violent revolution. ${ }^{5}$

On a national level, the Communists took the lead in organizing the unemployed. Numerically a small political party beset by internal factionalism and largely composed of non-English speaking ethnic federations, the Communist Party quickly recognized the political potential of the crisis and the opportunity to both spread its revolutionary program and build its membership along the lines of a long desired Anglo-American face. In 1929, the party began organizing worker's Unemployment Councils through its labor-based Trade Union Unity League (TUUL), forming the National Unemployment Council (NUC), an announced mass organization of the unemployed. ${ }^{6}$ Within a short period the NUC was indeed a mass organization, boasting branches in over 45 states, including every major urban city in the country. The NUC concentrated its efforts on direct action to obtain relief. Council members joined picket lines of striking workers, planned and led mass demonstrations for public relief, organized resistance to evictions and occupied 
offices of charity and public relief agencies. The growing strength and popular support of the unemployed movement could be seen not only in its local actions but in mass turnouts for their national protests. Over one million people participated in the first nationwide demonstration against unemployment jointly called for by the Communist Party on March 6, 1930. Over 100,000 demonstrated in Detroit, 50,000 in both Pittsburgh and Chicago and huge crowds paraded in Seattle, Philadelphia, Cleveland, Milwaukee, San Francisco and Los Angeles. In New York City, a crowd of over 100,000 were met by 25,000 police. In the ensuing violence, hundreds of protesters were arrested and scores injured and jailed. ${ }^{7}$

The Socialist Party also became active in organizing the unemployed. While the party's initial efforts centered on legislative reform and lobbying, by 1932 they began actively organizing the unemployed into Unemployed Worker's Committees and Unemployed Leagues. In Chicago, Karl Borders, a settlement worker and member of the Socialist Party, organized the Worker's Committee on Unemployment. By 1931, Border's committee claimed a membership of 15,000 . Borders would go on to organize the Socialist Party's Federation of Unemployed Workers Leagues, claiming a national membership of over 100,000 by 1932 , considerably more than the 40,000 estimated to belong to the NUC. ${ }^{8}$

A bitter rivalry between the Communists and Socialists ensued over the control and direction of the unemployed movement. Amidst Communist accusations that the Socialists were social fascists and Socialist countercharges that the Communists were totalitarians, the possibilities for one national organization seemed 
dismal. But with the Communist Party's shift to the Popular Front strategy in the mid-thirties, merger discussions began in 1934 and culminated in a new national organization, the Worker's Alliance of America, now encompassing the NUC, the Worker's League and previously unaffiliated councils. Overall, the 1936 merger brought together a national organization of some 1,600 locals with an estimated membership of over 600,000 . The semblance of unity that marked the merger was represented in its leadership as Socialist Party member David Lasser was named Executive Secretary and Communist member Herbert Benjamin organizational secretary. ${ }^{9}$

\section{The Quandary of Organized Labor}

At the onset of the Great Depression, the state of organized labor in the United States was one of considerable weakness, both in terms of numbers and political clout. With the virtual destruction of the revolutionary IWW in the wake of the anti-Communist purges following World War I, the American Federation of Labor (AFL) was the only national federation of labor unions. Established in 1886, the AFL, unlike the IWW, had focused its efforts upon the development of craft unions, mostly eschewing industrial workers. During the decade of the 1920 s and into the early 1930s, the AFL largely continued its practice of refusing to recognize organizing efforts among semi-skilled and unskilled workers, the bulk of the American work force. As a consequence, the growth of the AFL first stagnated and then declined precipitously. From a peak of membership in 1920 , when $17 \%$ of the 
work force was unionized, AFL membership had in fact been steadily declining from nearly five million to less than 2.5 million (or $9 \%$ of the work force) in $1930 .^{10}$

The AFL's initial response to the deepening economic crisis was in keeping with President Hoover's assurances that the crisis was temporary, and AFL leaders advised their membership that an upswing would soon be forthcoming. Indeed, fearful of federal intervention in the employment market, AFL President William Green met with a conference of employers called by President Hoover in early 1930 and pledged the AFL would avoid any strikes during the temporary crisis in exchange for a halt on wage cuts. Green would stand by this pledge in the summer of 1930 , even as 60 major companies imposed wage cuts on their workers. ${ }^{11}$

Growing unrest among both employed and unemployed workers and their efforts on a mass scale to organize would eventually modify the AFL's lack of enthusiasm for unionization of industrial workers. But even after congressional passage of the National Industrial Recovery Act (NIRA) in 1933, which provided federal sanction for the right of workers to organize unions, the AFL's response to the ensuring wave of union organizing in the industrial sector was conditional. New unions brought into the AFL as federal locals were deemed temporary and without voting rights until they could be absorbed into one of the existing craft unions. As a result, workers in factories were often split into a number of distinct craft unions, weakening any opportunity for collective bargaining. In addition, the AFL's discouragement of more militant organizing or bargaining tactics, such as the use of the strike, ran counter to the sentiments of many unionizing industrial workers. ${ }^{12}$ 
The militant mood of workers and union organizers within the worsening conditions of the economic crisis could not long tolerate the restraints of the AFL. Proponents of a new industrial democracy movement, promoting a vertical basis of organizing unions that included all workers in a shop or business, agitated inside and outside of the AFL for the federation to open its ranks to the masses of industrial workers in need of organizing. Among the first to experiment with developing a new national federation of unions was the Communist Party's Trade Union Unity League. Composed of relatively small unions with left-leaning or Communist leaderships, the TUUL left the AFL in 1929, seeking to organize new unions and draw existing unions out of the AFL. Eventually beset by internal criticism within the Communist Party that the TUUL was engaging in the ideologically heretical work of dual unionism, and unable to significantly expand its membership, the TUUL failed to develop a new national union of industrial workers. It would remain for another effort, embodied within the Congress of Industrial Organizations (CIO), to complete this goal of the TUUL and provide a nationally potent organization for industrial democracy. ${ }^{13}$

\section{The Crisis in Social Work}

The response of the profession to the Great Depression initially resembled that of the rest of the nation: confusion and uncertainty. Not unlike the AFL, social work's leadership saw no immediate need for special measures or significant federal intervention to deal with the temporary economic downturn. While increasing applications for assistance from the unemployed were already stretching the 
resources of private charity agencies in early 1930 , this upsurge in need was expected to subside shortly. Indeed, even the more liberal Survey paid scant attention to the stock market crash in a November 1929 issue, and the presence of Porter Lee on Hoover's PECE committee assured the profession that the modest public works program suggested by the committee would forestall any challenge to the private nature of the profession's relief-giving. For as PECE had declared in its statement of mission, its members would work to ensure that "...all possible efforts are made to provide each unemployed person with work, for work rather than charity is not only their choice, but their right."

Another measure of social work's relative confidence in the President and his advisors could be traced to the support of Hoover's 1928 election by distinguished leaders such as Jane Addams and Homer Folks. Even in his home state of New York, popular governor A1 Smith, Hoover's opponent in the election, failed to totally enthrall the liberal wing of the social work establishment. While Smith enjoyed the active support of the likes of Mary van Kleeck, Lillian Wald and William Hodson, others were less enthusiastic in their support. Future New Dealer Joanna Colcord conceded that there was little substantial difference between the candidates in terms of their record on social services; likewise, Edward Devine tempered his support of Smith by noting that Hoover was equally deserving of support among social workers. Even Paul Kellogg, editor of Survey and a sometime socialist, admitted he admired Hoover's cautious but socially progressive record. ${ }^{15}$ 
Despite the optimism within the profession that the Depression would prove temporary, the economy continued to shudder and decline throughout 1930. By the winter of 1931, Jacob Fisher recalls that there were few in the profession that did not concede the depth and apparent long-term nature of the crisis:

As factories closed and the weeks piled up their dreary quotas of the unemployed, the typical social worker rushed about in a frenzy of activity compounded in equal parts of a recoil from any thinking and a joyous self-immolation in a great crusade against hunger and want. Doubt, hesitation, critical-mindedness were luxuries no one could afford. The country was in the trenches and so were the social workers. ${ }^{16}$

Throughout the country, private charity organizations were swamped by unemployed workers and their families seeking assistance. As growing numbers of applicants stood in lines at relief agencies, sometimes stretching into the street, private charities were overwhelmed by both the sheer magnitude of the need and by the escalating costs required to meet that need. The economic collapse that was bankrupting business was no more kind to the volunteer agencies; by spring of 1932 some 400 agencies in New York City alone had closed their doors. The city-funded Home Relief Bureau, opened in 1931, was forced to turn away applicants by January of 1932 and would continue to briefly open and then close its rolls throughout the year as emergency grants of funds were sporadically provided by Governor Franklin D. Roosevelt's Temporary Emergency Relief Administration (TERA). ${ }^{17}$

Nor did the psychiatric social workers escape the clutches of the deepening Depression. The focus on the internal world of the client now emphasized in social casework was suddenly incompatible with the concrete demands of relief-giving. As 
clinics closed and social workers left to supervise public relief agency personnel or provide direct relief services, the opportunities for and seeming relevance of longer term intensive treatment methodologies rapidly diminished. One psychiatric social worker summed up what a growing number of social workers were now experiencing,

The clients I was seeing didn't seek shoring up of their ego strength anymore, they wanted food in their family's bellies...we realized that the game had changed but we didn't know which way to go. I knew that social work couldn't solve this so we started looking at the government for answers. ${ }^{18}$

Indeed, the profession's arena of control over relief giving was being severely challenged. By 1931 it was clear that private charities could no longer adequately respond to the massive character of unemployment and that the entire system was in danger of imminent collapse. As states and cities began operating their own relief bureaus, increasing numbers of untrained and uncredentialed relief workers were hired to meet personnel needs that the small profession of social work could not supply. Threatened by the profession's own inability to ameliorate poverty within the confines of the voluntary agency, and concerned over the diminution of its professional standards of training and practice in the public relief agencies, the AASW moved towards support of federal responsibility for relief. As opposed to clinical treatment issues, debate on the role of the federal government in relief operations and the protection of professional standards in that relief dominated the meetings of the NCSW in 1931 and $1932 .{ }^{19}$ 
Much had changed in the mood and direction of the profession since the heady days of 1929. At that time, as Porter Lee elevated function over the cause of reform in social work's calling, William Hodson, executive director of the New York City Welfare Council, had warned social workers of the pitfalls of engaging in political activity:

...while the political support of men or parties raises problems for the social worker in their most difficult form, open participation in public affairs...also presents difficulties for the obvious reason that the social worker is not a free agent but the employee of the board of directors of his organization. In the public mind his action may be interpreted as having the sanction of the board, thus, by implication, committing the board members and the organization as a whole in a way which may be distasteful and embarrassing. ${ }^{20}$

Even as the economic crisis deepened in 1930, NCSW President Miriam Van Waters made no reference to it in her Presidential Address to the NCSW, instead buttressing Porter's earlier proclamation of an objective, more politically neutral casework:

The family case worker and the psychiatric social workers are alike in their reliance for treatment upon constructive attitudes, stressing competence and adequacy rather than humility and dependence. Thus the social worker is sharply differentiated from his ancestor, the philanthropist. His attitude toward personality sets the social worker far apart from the social reformer who adopts a program of militant social welfare, and fights the opposition with hatred. In so far as public opinion is aware of social work it identifies it with reform or uplift movements. This is a mistake. There is evidence that social workers derive from trends of thought quite distinct from 'reformers.' Reformers have commonly a low opinion of mankind. ${ }^{21}$

But now in the grim times of 1932, the profession was rethinking its role and responsibility in promoting public policy. The 1932 NCSW meeting in Philadelphia 
reflected the change in mood and tenor. As Survey correspondent Gertrude Springer noted,

It was not a gay conference. There was no dancing in the hotels after the evening meetings, no outbursts of community singing in lounges and lobbies...All in all it was a deeply earnest Conference, sober but not somber, determined but not despairing, purposeful but not panicky. Not for years has a Conference in and out of hours been so truly a forum of discussion. ${ }^{22}$

Delegates now overwhelmingly supported the AASW's call for President Hoover to provide federal support for public relief. The National Federation of Settlements distributed resolutions they had adopted calling for federal intervention and the enactment of unemployment insurance. William Hodson, unlike 1929, now exhorted delegates that the profession, under the leadership of the AASW, must combine their "knowledge and experience" into a program of legislative action and "...the ever greater burden of responsibility for public policy."23 At the same time, Hodson urged social workers to recognize that the increasing number of untrained workers being employed in relief efforts threatened a "debasing" of the profession and required action to protect professional standards. ${ }^{24}$

While the majority of speakers and delegates at the NCSW now acknowledged the necessity of federal intervention, coupled with the profession's consultation and leadership, an emerging radical wing within the profession began to stake out a different alternative for social workers. Once again, Mary van Kleeck would assume the role of political gadfly as she addressed the delegates. Reminding the conference of the admonitions for national planning and an alliance with the 
labor movement that she and Roger Baldwin had made to the NCSW in 1924, van

Kleeck now urged delegates to support a fundamental restructuring of the nation:

I call attention to the fact that it is now eight years since that report was made in Toronto and that neither in 1912 nor in 1924 was there any reference to the idea of planning in the sense in which is being discussed today. Since that date the experiment in planning in Soviet Russia has emerged as a definite procedure. We must clearly recognize that Soviet Russia is the only country in the world which can present a demonstration of social economic planning directed toward raising of the standards of living of all people. I confess that I grow somewhat impatient with the efforts made in this country to differentiate the current discussion of planning from Russian planning. It seems to me unscientific thus to eliminate consideration of an experiment which we should study in order to discover not only its technique but its sources of power. ${ }^{25}$

Unlike the tepid response of 1924 , this time van Kleeck moved the audience to loud applause, such that one observer noted van Kleeck "...was forced to get up and bow before the applause died down." ${ }^{26}$ In 1932, van Kleeck's position to the left of the mainstream was no longer as isolated as in 1924. Rather, van Kleeck was now articulating the position of a new tendency in social work, the dissenting voices of a self-proclaimed rank and file movement in social work.

\section{The Rise of the Discussion Clubs and Practitioner Groups}

As the profession struggled to cope with the challenges posed by the economic crisis, many social workers searched for an individual and collective understanding of the forces that had brought about such a massive economic collapse and the avenues for recovery. For some, the confidence of the profession's leadership in the established political order and the seeming obsession of the AASW 
on the more mundane issues of professional standards and membership requirements was eerily out of touch with the sense of desperation experienced in the lives of their clients and neighbors. Dissatisfied with the outlets of expression available through professional channels, and seeking exposure to alternative, often radical, explanations of and solutions for the crisis, a new forum for these mostly young social workers emerged in New York City, the Social Workers Discussion Club. As Jacob Fisher, an early participant and leader in the New York discussion club explained,

Social workers in the early years of the Depression who felt dissatisfied with the thinking of the social work establishment, unhappy about the political and economic order, and anxious to do something about these two evils, found that a natural first step was a meeting to talk things over. You talked things over to find out how many felt the way you did. When you had a like-minded nucleus, you held a meeting to influence other social workers. In time a following was established. ${ }^{27}$

The New York Social Workers Discussion Club held its first meeting in the spring of 1931 , with the avowed purpose of providing an "...open forum for the analysis of basic social problems and their relation to social work. ${ }^{, 28}$ Held in a rented hall, the first meeting was billed as a debate on the causes and cures of economic depressions. The New York club became a model for social workers in other cities and by 1932 , discussion clubs had been formed in Chicago, Philadelphia, and Boston. The discussion clubs would continue to expand throughout the country, including cities such as Baltimore, Cleveland, Pittsburgh, Seattle, Los Angeles and San Francisco. ${ }^{29}$ 
For the next four years the discussion clubs did indeed serve as a forum for debate and critical analysis as participants addressed such subjects as unemployment relief, the role of psychiatry in social work, civil rights and the role of trade unions in social work. ${ }^{30}$ The appeal of the clubs and the underlying conditions that made their rapid expansion possible were outlined in a 1933 pamphlet published by the New York club:

The chorus of voices calling for a new order grows louder. As social workers with an expert knowledge of misery in all its manifold forms, we cannot afford to remain outside the forces shaping America to a new adjustment. We must be prepared to contribute the full measure of our hard-won understanding...Out of these meetings has grown an enlargement of the social horizon, a participation in and endorsement of movements of social significance, vitalizing, after a decade of absorption in technics and statistics. $^{31}$

While the clubs were billed as an open forum for discussion, not all social workers who created and participated in the discussion clubs shared Fisher's more benign explanation regarding their origin or purpose. Eleanor Cohen, a rank and file social worker in Chicago, explains,

The [discussion] clubs were not a product of the [Communist] Party, but we were instrumental in their organization and direction. In Chicago, the Communist group in the club took the main responsibility for their organization and direction. Of course, we tended towards speakers that represented the views of labor, the unemployed workers and the forces allied against social fascism. To the best of my memory, the same was true in Cleveland, Los Angeles, Seattle and most of the clubs. ${ }^{32}$

Regardless of the dispute between Fisher and Cohen concerning the role of the Communist Party in the development and management of the discussion clubs, the 
clubs clearly sought politically left analyses and speakers. As Fisher notes, the young social workers attending the discussion clubs "...found the 'Communist thinking' expressed by the speakers a novel and refreshing experience."33 But not all the presentations apparently met the expectations of its audience. Fisher recalls one particular meeting on the influence of social forces in literature featuring Mike Gold, a prominent Communist writer and columnist for the New Masses and the Daily Worker:

Contrary to the expectations of the C.P. members and sympathizers who had organized the meeting, Gold made a less than overwhelming impression on his social work audience. As a speaker he was not the articulate persuasive advocate he was pen in hand... Worse, he seemed to many of his auditors to be patronizing them. Tired radicals and effete intellectuals, said Gold, were becoming disillusioned with capitalism because they had illusions to begin with. Raised eyebrows; was he talking about us? Capitalism, Gold went on, produced cripples, insane men, unemployed men, hungry children, and maladjusted virgins for social workers to putter with. The social workers in the room fidgeted; a few yawned; one young woman muttered loudly, 'What does he think we are, clients?' Restless members of the audience puffed furiously at their cigarettes. Some left while Gold was still talking...The communists may have a case, I thought, but they would have to do better than this. ${ }^{34}$

The discussion clubs soon moved beyond merely serving as a forum of discussion; increasingly, they provided an organizational base for social action. In New York City, members of the discussion club joined protests of the Harlem Unemployment Council in the spring of 1931, participating in a march in Harlem protesting discriminatory practices in the State Employment Service and the inadequacy of relief services to unemployed African-Americans. The club officially 
endorsed a mass demonstration at city hall against unemployment in November of 1931 and raised funds for the first national hunger march on Washington, D.C. in 1932. The club also supported the Lundeen Bill (the Workers Unemployment and Social Insurance Bill) and raised funds to support the Amsterdam Congress Against War. ${ }^{35}$

In 1934, the New York club made its first independent foray into political action, forming a committee to investigate relief practices within the city's Emergency Home Relief Bureau (HRB). The committee report harshly criticized the $\mathrm{HRB}$ for inadequate standards of relief, charging that relief allowances and rent assistance funds were far below levels “...allowing for minimum health and decency. ${ }^{36}$ On May $15^{\text {th }}$, members of the committee, joined by Harry Lurie, Lillian Robbins and John Slawson, prominent social workers in the Jewish federation societies, met with public welfare department director, William Hodson, to present their findings and recommendations. In a contentious meeting, the committee demanded immediate increases in relief allowances, an abolition of residency requirements for relief and a prohibition of evictions and foreclosures. Asked by the committee to publicly support increased funding as well as the report's other recommendations, Hodson demurred. While acknowledging that "The whole relief picture is a flop" and personally agreeing with the minimum standards recommended by the committee, Hodson rejected the committee's request that he openly support their recommendations, reportedly telling the delegation that such a position would “...only get me in trouble." ${ }^{37}$ Following Hodson's rejection of the committee report, 
club members issued an open letter, distributing it to Hodson, employees of the $\mathrm{HRB}$, and the mayor. In the letter, the club outlined its recommendations and version of the meeting with Hodson, condemning Hodson for his recalcitrance:

Such an attitude of fear on the part of a social worker in public office assigns to social work the job of constantly apologizing for pittances...At the same time, we must condemn your encouragement of police violence against the unemployed seeking to gain those very standards approved by you in your statements to the committee. ${ }^{38}$

Similar activism marked other discussion clubs across the country. In Philadelphia, club members joined with farmers and others to help distribute free milk to the unemployed. Members of the Newark, New Jersey, club endorsed and participated in strike activities of employees of the city's largest newspaper, The Ledger. In Chicago, the largest discussion club outside of New York, club members were active in raising funds for the legal defense of the Scottsboro Boys and labor organizer Tom Mooney and participated in actions of the local unemployed councils. The Chicago club was also noted for its early attention to personnel standards and practices in relief agencies. The Chicago club actively publicized and organized against relief agency practices of unpaid vacations, uncompensated overtime and salary reductions imposed by the Illinois Emergency Relief Commission. ${ }^{39}$

As the discussion clubs of the emerging rank and file movement proliferated throughout the country, another movement, less politically-conscious than the discussion clubs, began to develop within AASW chapters during 1933. The socalled "practitioners' movement" ${ }^{40}$ represented the concerns of social workers in the 
AASW who feared the collapse of professional standards and training in public relief agencies. Particularly concerned with salary cuts being instituted in relief agencies, the social workers who joined practitioner groups also represented a growing rift within the AASW between leaders of AASW chapters, usually agency executives, and regular chapter members who were primarily employed as direct service practitioners. Believing that AASW chapter leaders were unconcerned with declining salaries (and in fact, often the instigators of such wage reductions within their agencies) and discouraged the participation of practitioner members in chapter decision-making, practitioners formed ad hoc study and discussion groups in three AASW chapters in Chicago, New York and St. Louis. ${ }^{41}$

While membership in practitioner groups often overlapped with the social work discussion clubs, the agenda of the practitioner groups was considerably more tame than that of the clubs. The first practitioner group, formed in Chicago, in fact articulated no specific program, stating that it “...wanted merely a medium in which workers might be free to express themselves on any subject with interested them., ${ }^{, 42}$ To ensure this free expression, membership in the group was extended to all AASW chapter members with the specific exclusion of chapter executives. In a similar fashion, the New York group accused the AASW chapter of confining itself "...to a small inner self-perpetuating circle of executives, which prepares the program, steers committees, and makes all important decisions"; accordingly, the group concentrated its efforts on providing the "...younger worker the opportunity for leadership and [preparation] to assume a more active role in the chapter itself. ${ }^{, 43}$ In St. Louis, the 
practitioner group was less hostile, conducting several studies and making recommendations to the AASW chapter on issues pertaining to personnel standards and training for social workers in the public relief agencies. ${ }^{44}$

While the practitioner groups would never formally expand beyond these three AASW chapters, they provided another indication beyond the discussion clubs of the unrest that social workers were feeling within the confines of the AASW and the growing concerns that social workers were expressing about the worsening workplace conditions in relief agencies and private charities. Despite their limited influence and number, the practitioner groups also served an important function for the emerging rank and file movement: providing entrée with the AASW. In this regard, Fisher notes:

The movement's leadership recognized that within the top councils of the AASW there were people like [Mary] van Kleeck and [Harry] Lurie, who could influence the association to take a more 'progressive' position on relief, social insurance, and jobs for the unemployed, and that cooperation was possible and even useful on specific issues. The existence of the practitioner groups could facilitate such cooperation. ${ }^{45}$

\section{Social Work Unions Take Root}

The initial stirrings of the discussion clubs and practitioner groups represented a growing consciousness within the profession that the conditions of the Depression required not only social action on behalf of clients but a focused attention on the working conditions experienced by social workers themselves. While the practitioner groups were limited in membership to AASW members, the discussion clubs embraced the growing number of uncredentialed relief workers that 
represented a significant proportion of the staff in public relief agencies. The rapid influx of these new, largely uncredentialed social workers was a direct result of the New Deal programs instituted by the newly-elected President, Franklin D. Roosevelt. Within months of Roosevelt's taking office, a wide array of legislation was enacted to restructure the economy and provide relief to a beleaguered population, including the Civil Works Administration (CWA), the Public Works Administration (PWA), the National Industrial Recovery Act (NIRA) the Farm Credit Act, the Railroad Coordination Act, the Tennessee Valley Authority Act, The Home Owners Act, and the Civilian Conservation Corps (CCC). In the area of direct relief, Roosevelt also acted quickly. On May 12, 1933 he signed into law the Federal Emergency Relief Act (FERA), providing some five hundred million dollars for immediate use by states for relief of the unemployed. The FERA would prove to be the major source of direct relief in the early years of the New Deal, providing money to be distributed among broad categories of the poor and unemployed. Its broad discretion in granting relief would swell relief roles, so much so that by 1934 some twenty million would be on public relief. ${ }^{46}$

As states expanded their relief services under the terms of FERA, thousands of caseworkers were required in order to process applications and determine need. With only 186 students receiving an M.S.W. degree nationwide in 1933, the profession did not contain nearly the number of social workers required to provide services. ${ }^{47}$ Instead, relief agencies looked to the unemployed themselves, and many of the new case workers were hired through the CWA and PWA public works 
programs. Among these young relief workers, the poor working conditions of relief agencies and resentment of credentialed social workers who were often employed as supervisors, provided a potent combination in favor of unionization. Bronislaus Zukas, an uncredentialed relief worker with New York City's Emergency Home Relief Bureau in the early 1930 s recalls the sometimes explosive atmosphere:

We were angry. The government, big business and the AASW were all in bed together. They kept saying everything would be fine, that Hoover and then Roosevelt were better than living with radicals, Communists and unions. Our offices were terrible. They were overcrowded, smelled like toilets...We didn't control how many clients we had, there was no overtime or compensation. Sometimes I worked 12 hours a day, six days a week for about thirty bucks a week...The MSW's were condescending to us 'untrained' caseworkers. They acted like they were the only ones who knew how to run things. Hell, we were the ones who had been unemployed, we knew what it meant to be poor, not them....we had to build unions. ${ }^{48}$

Despite the tensions rampant within the public relief agencies, it was in the private volunteer agencies that social work unionization would first take hold. Like all private charity organizations, New York's Jewish Federation Societies were experiencing severe financial pressures in 1931 as its constituent agencies struggled to meet the increasing needs of the Jewish community. In November 1931, Federation officials announced an across-the-board wage cut for all employees, including nurses, social workers, doctors, porters and clerical workers. The Association of Federation Social Workers (AFSW), established in 1926 to represent social workers' concerns with professional standards and training, was forced to rethink the cooperative arrangements it had previously held with agency 
administrators. Many of the AFSW's leadership were also members of the New York Workers Discussion Club, and they were instrumental in moving the AFSW to reconstitute itself as the Association of Federation Workers (AFW), now more in the form of a collective bargaining union representing all classes of employees. ${ }^{49}$

The immediate hopes of the AFW to roll-back the wage cuts and win recognition as the union of Federation employees were quickly dashed, as Federation officials refused to meet with them. After repeated attempts, the union representatives were finally granted a meeting with the federation's executive director, who promptly rejected all union demands. Unwilling to go on strike, the AFW could do no more than publicize the plight of its members in the press and struggle to maintain its membership through the development of "worker's councils" in the Federation's constituent agencies. ${ }^{50}$

Following a second salary cut in the fall of 1932, the AFW was more successful. Organizing efforts to combat the cuts rapidly expanded. Following a mass protest meeting and a petition drive among Federation employees, the board of directors announced a $95 \%$ restoration of cuts. Buoyed by the restorations, AFW membership rose to over 400 by September 1933, and the AFW now clearly distinguished their interests with that of the federation board:

The higher income class, who are represented by the Boards of private welfare agencies, set the social work program and contribute the funds that pay our wages. By reason of this position they collectively constitute our employer. If they do not want an adequate social work program they should be prepared to face the consequences. Theirs is a grave responsibility. ${ }^{51}$ 
But the restorations proved short-lived. Shortly after partially restoring the cuts, the Federation, now faced with a ruling that FERA funds could not be used by private agencies, announced a $20 \%$ cut in 1933 . Once again the AFW swung into action, holding a mass protest meeting and this time producing a petition signed by over 700 employees. ${ }^{52}$

Following a year of stormy and unsuccessful negotiations, on February 7 , 1934, the AFW staged the first recorded work stoppage in social work history. Five hundred Federation employees left their workplace, gathering for a mass rally at a local high school with hundreds of supporters representing unemployed councils and other unions. Observers reported a spirited meeting, highlighted by the reading of a letter of support from Mary van Kleeck and the appearance of delegations from the Graduate School for Jewish Social Work and the New York School of Social Work. Following the work stoppage, the Federation board rescinded all previous salary cuts. $^{53}$

The initial, though halting success of the AFW in organizing social workers was quickly, and more successfully, emulated by New York City's public relief workers. Relief workers employed by the city's Emergency Home Relief Bureau (HRB) held an initial organizational meeting of the Emergency Home Relief Bureau Employees Association (HRBEA) in December 1933. While only 100 of the 5,000 workers employed by the HRB attended, a continuing series of mass meetings were held during the month, and by the fourth meeting over 1,000 employees had joined the union. In January 1934, a committee from the HRBEA met with HRB 
administration seeking recognition and presenting a list of union demands. Faced with the rapid consolidation of the union among its employees, the HRB recognized the union and agreed to a majority of the union's key demands, including: wage increases ranging from $14-80 \%$ for guards, matrons, clerical staff, bookkeepers and relief workers; the abolition of enforced overtime; coverage by industrial compensation insurance; provision for sick and vacation leave; and the reinstatement of several employees previously dismissed for what the union considered unjustified grounds. $^{54}$

The considerable victory of the HRBEA propelled it into the leadership of now emerging social worker unions in other cities around the country. With the subsequent transfer of the HRB into the city's welfare department in 1935 , the Association changed its name to the Association of Workers in Public Relief Agencies (AWPRA) and began organizing the entire department. In August 1935 the AWPRA, now with nearly 5,000 members, entered into a formal collective bargaining agreement with the city. The importance of this agreement was prominently publicized by Social Work Today:

August 29 will be remembered as a memorable date. On that day a collective agreement between the Home Relief Bureau of New York and the [AWPRA] ...went into effect, the first of its kind in social work. The Association ...is the largest of its kind in the country. The precedent thus established may well serve as a powerful stimulus to demands by employee associations in other cities for similar agreements. ${ }^{55}$

In fact, the success of both the AFW and the AWPRA in organizing social workers and relief workers helped to launch similar organizing efforts throughout the 
country in 1934 and 1935. In Philadelphia, over 200 employees turned out to form the Association of Philadelphia County Relief Board Employees, despite resistance from Relief Board Executive Director Dorothy Kahn, a national leader within the AASW. Welfare workers in Detroit formed the Association of Public Welfare Workers, and in Cleveland, the Family Service Workers Association won salary increases for caseworkers in the county's Relief Administration after threatening a work stoppage. Similar wage increases were won by the Associated Relief Workers of Allegheny County in Pittsburgh. Members of the Chicago discussion club formed the Federation of Social Service Employees within the Illinois Emergency Relief Commission. Keeping with the club's previous interest in personnel and training standards, the Federation established a "Committee on Standards of Work and Working Conditions," including representatives from the city's largest social service agencies. ${ }^{56}$ Union organizing in the private charities also met with success, including employees in agencies in New York, Brooklyn, Boston, Chicago, Cincinnati, Detroit, Philadelphia, and Minneapolis. All told, by the end of 1935 over forty unions in private and public relief agencies had been established throughout the country in over twenty cities. With the creation of the Administrative Workers' Union of the Alameda County State Emergency Relief Administration, the rank and file movement had now moved across the country from the east to the west coast. ${ }^{57}$ The Birth of Social Work Today

The rising tide of unionization among social workers found a national voice in the pages of Social Work Today, a journal established by the New York Social 
Workers Discussion Club. ${ }^{58}$ From its inception in 1934, Social Work Today would be recognized as the quasi-official journal of the rank and file movement, reporting not only on the progress of unionization but articulating the political and philosophical views of the movement's leadership. In its opening editorial Social Work Today, unlike journals such as the thoroughly mainstream Compass and the liberal leaning Survey, clearly placed itself at odds with the social work profession:

[Social Work Today] aims to meet the need for a frank, critical analysis of basic social problems and their relation to social work not obtainable through established professional channels. Its province will be all of social welfare. It will promote an interest in the fundamental reorganization society must undergo to provide security for all, and will support labor's struggle for a greater measure of control as the basic condition for the reorganization. ${ }^{59}$

In staking Social Work Today's claim as an alternative voice within the profession, the editorial attempted to locate the economic and political bases for the emergence of the rank and file movement in social work:

Under the cumulative pressure of four years of continuous contact with the victims of our chaotic social order, some have learned to question the traditional dogmas of the profession and to examine critically the shibboleths of 'awareness,' 'bearing witness,' 'social engineering,' and 'community integration.' They are painfully aware of many things that do not submit to awareness. They wonder who is doing the engineering and whether it is social. They suspect that talk of community engineering is a pleasant fiction to hide the ugliness of our class society. They are sick of merely bearing witness.

There is a growing body which is applying in another spirit the charge to all social workers, to know their clients and to help them free themselves. They have heard the voice of labor speak compellingly in its own behalf. They are coming to feel that whatever skill and knowledge they may have can be put to most 
effective use supporting by publicity and action the organization of labor and its fight for adequate relief and social insurance. ${ }^{60}$

Indeed, the first issue of the journal took seriously the editorial's promise of a "frank" analysis regarding social crises and the profession, marking its debut as a continual thorn in the side of the mainstream profession. ${ }^{61}$ Its lead article presented a satirical and critical account of a recent AASW conference convened to define the organization's position regarding federal relief policies. Taking pains to note for readers that the conference had no apparent intention of deciding on such positions, the article acridly described the AASW participants as "...predominantly middleaged, predominantly women, predominantly executives. Most the talking is done by the men. The women take notes." ${ }^{.62}$

Noting a contentious exchange on the fate of the Civil Works Administration between Harry Lurie and "lean and cocksure" FERA administrator Harry Hopkins, the article highlights Lurie's admonition to the conference that applause for Hopkins should not be taken as support of government relief programs. ${ }^{63}$ The article concludes its account, whimsically describing the conference's adjournment:

Finis. The Committee on recommendations reports in the evening, but why stay, people ask, it's all over. Delegates sit about in the lobby and gossip. Shall we take the seven o'clock train or the eight o' clock? The women with the bleached hair and velvet wraps pass through to dinner. ${ }^{64}$

Other articles of a more serious tone reported on the National Convention Against Unemployment, a report of the Joint Committee on Unemployment's statement before Congress in support of massive increases in federal relief efforts, issues of 
racism within the programs of the National Recovery Act and a brief history of unionization efforts in social work. ${ }^{65}$

The appearance of Social Work Today received mixed reviews from rival professional journals. While the publication of Social Work Today was ignored in the pages of Compass, Survey noted in its arrival in its April 1934 issue:

There are undoubtedly in this troubled land many social workers even among the 'predominantly middle-aged, predominantly women' at whom SOCIAL WORK TODAY takes a little fling, who 'are sick of merely bearing witness.' They will find in SOCIAL WORK TODAY a forthright expression of their impatience and of their pressure-mindedness. ${ }^{66}$

The other major journal in the field, Social Service Review, took a more welcoming stance:

An active group of New York social workers are to be congratulated in having organized for the publication of a new professional journal. This magazine is to appear monthly and should be an asset to a profession in which, as yet, so small a periodical literature has been developed. The Review shares with other social workers an appreciation for their undertaking. A new publication in these days, calls for courage, and the New York group has shown that courage is not lacking. ${ }^{67}$

Through the pages of Social Work Today, the incipient rank and file movement would develop and express its program of unionism and progressive social change. From an initial circulation of 1,000 , the journal would increase its subscription base to nearly 5,000 by 1936 as discussion clubs and union members sold subscriptions and raised funds for its operation. ${ }^{68}$ Opening its pages to both the left wing of the profession and the representatives of the Unemployed Councils, the Socialist and Communist parties, and organized labor, the journal tackled a broad 
range of social and political issues and causes. In later years, the journal's critical analysis would lead it and the social work unions it represented to be condemned by both congressional investigators and influential members of the profession as controlled by the Communist Party, charges that would help lay the groundwork for the eventual destruction of the rank and file movement.

\section{The Rank and File Organizes}

With the rapid proliferation of social work unions nationwide, the presence of numerous discussion clubs and practitioner groups, and a new journal representing the cause of progressive social work unionism, leaders within the rank and file movement laid plans for the development of a national organization in 1934. Rank and file activists attending the 1934 NCSW voted to create a National Coordinating Committee (NCC) of social work unions, charging the publishers of Social Work Today with planning and coordination of a meeting to form the organization. ${ }^{69}$ Following the conference, the executive committee of the New York Social Workers Discussion Club polled rank and file groups throughout the country seeking their opinions on the role of such a national coordinating body, suggesting procedures for its development and operation, and soliciting participation at a founding convention. In December 1934 the club issued a formal call for a February 1935 conference in Pittsburgh. In its call, the club outlined the proposed functions of the NCC:

The dissemination of information and advice on practitioner activities. The promotion of protective organizations and discussion clubs. The promotion of rank and file sentiment for adequate standards for workers in public agencies. 
The promotion of rank and file sentiment for adequate social welfare standards.

The coordination of practitioner activities at National Conferences. $^{70}$

The first national convention of rank and file groups opened its three-day meeting on February 22 in Pittsburgh, Pennsylvania. A report from the conference's credentials committee recorded 45 delegates representing 30 organizations. Seventeen of the represented groups were identified as protective organizations (unions), six as discussion clubs, four were classified as practitioner groups, and three groups represented unemployed councils or other organizations. The total membership represented in these 30 groups was impressive, totaling 8,810 . Delegates clearly represented the direct service orientation of the unions; 32 of the delegates were caseworkers (19 from public agencies and 13 from private agencies), with the rest consisting of supervisors, clerical workers, research workers and unemployed delegates. $^{71}$

At the opening session, delegates were treated to the reading of formal greetings from organizations that could not attend as well as the ideological leaders of the movement. Mary van Kleeck's message congratulated the convention, callings its efforts "...of great importance when social workers must relate themselves to industrial workers and those in other professions in united program for social security."72 Bertha Reynolds assured delegates in her message that "...the convention is certain to make history. It is for you who are facing the issues of this critical time most courageously to shape the future of social work." ${ }^{, 73}$ True to his 
explicit politics, Roger Baldwin's remarks particularly stirred the delegates:

"Warmest greetings to those of you who are carrying on a vital job begun by pioneer social workers in the class struggle. We were few those days. You are many and may you be many more. ${ }^{74}$

Over the next three days, delegates laid the foundation for a new national body, the National Coordinating Committee of Rank and File Groups in Social Work (NCC). The NCC was conceived as a center for the exchange and coordination of information and advise on the organization of rank and file unions, to advocate for adequate relief standards and public works programs, and to coordinate “...cooperative action with organized labor in their struggles for the right to collective bargaining, and for the defense of civil liberties." ${ }^{, 75}$ A committee to lead the activities of the NCC was also established consisting of Jacob Fisher as Chairman, David Kanes of the Philadelphia County Relief Board Employees Association as eastern regional vice-chairman, Joseph Levy of the Chicago Federation of Social Service Employees, midwestern regional vice-chair, and Bernard Riback, president of New York's EHRB Employees Association as Secretary. ${ }^{76}$

Reflecting the rank and file movement's primary concerns with workplace security and the face of public relief policies, considerable debate went into the adoption of related reports and recommendations. In their report, “A National Social Welfare Program," the convention decried the inadequacy of New Deal programs, 
accusing the Roosevelt administration of abandoning the needs of the unemployed to satisfy the desires of business:

The social security program of the Administration proceeds upon the basis of 'sound caution' and consideration of the 'capacity of industry to pay,' rather than upon a true evaluation of the needs of the workers of America. ${ }^{77}$

The report equally, but less directly, criticized the AASW and the mainstream of the profession for its general support of the New Deal and its remoteness from the victims of the Depression:

Will social workers, as a large professional group, remain aloof from.... people's movement? The attempts they have made to introduce proposals without the active participation of those who have the most to gain from them, have proved to be either impotent or deliberately misleading. The critical nature of the problem of insecurity with which the American people is faced, will increasingly force social workers to take sides. ${ }^{78}$

The report concluded with a summary of the rank and file's estimation of the fundamental nature of the economic crisis:

The underlying conflict broadly is between Labor and Capital. Social workers should seek to understand fully the nature of this conflict, the economic and political power that goes with the concentrated control of wealth, and the sometimes brutal forms through which wealth defends itself. Unparalleled economic power yields only to economic pressure. Labor, by force of necessity, finds itself in the front line trenches in the struggle for security. ${ }^{79}$

Convention delegates were equally strident in their demands for the right of workers to engage in collective bargaining in public and private social welfare agencies. Condemning the growing phenomenon of retrenchment in both sectors, the convention established a program for its unions, including: open hearings for 
workers threatened with dismissal; mandatory yearly salary increases; the principle of equal pay for equal work; adequate housing and working conditions in agencies; the abolition of compulsory overtime and quotas; reductions in caseloads; and minimum standards for vacation, sick leave, and maternity leave. Finally, the program established the primacy of unions, not professional associations, in ensuring adequate working conditions:

The Convention recognizes as primary in importance the employer-employee relationship between rank and file social workers and administrative authorities and executives. Workers in social agencies are subject to the same economic hazards as workers in industry and commerce. This is equally true of professional and non-professional workers in social agencies. We therefore endorse the principle of protective organization as the most effective method of attaining these ends. ${ }^{80}$

In addition to these major reports, the convention adopted a number of resolutions, including support of the Lundeen Bill on unemployment and social insurance, funding of a new Federal Works Program, and support of legislation to allow collective bargaining in all federally-funded agencies and programs. Condemning recent dismissals of a number of social workers involved in union organizing, the convention called upon FERA to investigate the circumstances of these dismissals and prevent what they considered discrimination based on union involvement. Finally, the convention adopted a resolution opposing all forms of racial discrimination and directed the NCC to hold all future meetings in facilities with non-discrimination policies in regard to meetings, sleeping quarters, and dining accommodations., 81 
As the Pittsburgh convention came to a close, delegates might have reflected on the dramatic changes that had occurred in the profession in a period of just five years. The relative confidence and complacency in the profession of 1929 had been shaken to its core, its hold on the field of social welfare now under challenge externally and internally. From the outside, a dramatic shift from private charity to public relief had undermined the profession's hegemony over both relief policy and practices. Internally, a new group of social workers had arisen to challenge traditional conceptions of the professional social worker and of the relationship of social workers to their employers, now successfully organizing a national organization of nearly 9,000 members. And when rank and file delegates would convene for their second national convention in 1936, their ranks would swell to some 12,000 . While not all the members of the affiliated organizations of the NCC were social workers, the rank and file movement now could claim a membership larger than that of the AASW (which did not achieve a membership of over 10,000 until 1940). ${ }^{82}$

For the leaders of the profession, they could find comfort in the close alliance they had attained with the Roosevelt administration through the presence of Harry Hopkins, Frances Perkins, Ewan Clague and other leading social workers in the New Deal brain trust. While the primary responsibility of relief had now shifted from the private sector to the federal government, at least the AASW had a place at the table. But as the rank and file movement began to assert the power of both its numbers and its critique of the profession, there were reasons for continuing concern. For those 
who read the open letter to social workers from the NCC, distributed at the 1933

NCSW and published in Social Work Today, the threat may have appeared quite real indeed:

We appeal not only to the rank and file in this letter, but to all social workers who value their professional integrity and who seek, above all, to have it grounded in the welfare of the

American...peoples. There are tasks which you cannot shirk, tasks for all social workers inside and outside the rank and file movement who cannot accept a program of reduction in the standard of living of the people of...America; who stand fast against attacks on civil liberties; against racial discrimination; against all devices leading to fascism in America, whether open or disguised.

There are organizations thorough which you can play an important role, the American Association of Social Workers, state and local conferences, the various other professional groups in the field of social work. You can do much to align these organizations into a common front with us against the forces of reaction and despair. The road for unity on our common issues is very great. ${ }^{83}$ 


\section{Notes to Chapter 3}

1. Mary van Kleeck, "The common goals of labor and social work," in Proceedings of the NCSW, 1934 (Chicago: University of Chicago Press, 1934), p. 303.

2. John K. Galbraith, The great crash, 1929 (Boston: Houghton-Mifflin, 1955); Frances F. Piven and Richard Cloward, Poor people's movements (New York: Pantheon Books, 1972); Watkins, The Great Depression.

3. Irving Bernstein, The lean years: A history of the American workers, 1920-1933. (Baltimore: Penguin, 1966), pp. 272-278; William Bremer, Depression winters: New York social workers and the New Deal (Philadelphia: Temple University Press, 1984), pp. 89-91. Indeed, Hoover did not even accept estimates of over three million unemployed in 1930 from the U.S. Census Bureau. Hoover, claiming that many of those counted in the figures had no intention of seeking employment, changed the estimate to a little less than two million (Bernstein, The lean years, p. 268).

4. Piven and Cloward, Poor people's movements, p. 49.

5. Bernstein, The lean years, pp. 416-436; Piven and Cloward, Poor people's movements, pp. 48-55; and Klehr, The heyday of American communism, pp. 4962.

6. Benjamin, "After a decade of mass unemployment," The Communist, pp. 259277; Richard Boyer and Herbert Morais, Labor's untold story (New York: United Electrical, Radio and Machine Workers of America, 1976), pp.: 260-266.

7. Benjamin, Ibid.; Boyer and Morais, Ibid.; Klehr, The heyday of American communism, pp. 49-53.

8. Piven and Cloward, Poor people's movements; Klehr, The heyday of American communism, pp. 64-65

9. James Lorence, Organizing the unemployed (Albany: State University of New York Press, 1996), pp. 122-123; Piven \& Cloward, Poor people's movements, pp. 75-76. The total membership of the Alliance is subject to considerable debate. Piven and Cloward accept the Alliance's official claim of 600,000 . According to Klehr (The heyday of American communism, p. 297), other estimates from its own leaders ranged from 23,000 to 300,000 at the time of merger.

10. Bernstein, The lean years; Aleine Austin, The labor story (New York: CowardMacCann, 1949); Piven and Cloward, Poor people's movements, pp. 115-116. 
Bernstein cites similar figures in his The lean years, estimating an AFL peak of $5,047,800$ in 1920 and a decline to slightly over $3,000,000$, or 10.2 percent of the non-agricultural workforce in 1930 (p. 84).

11. Bernstein, The lean years, pp. 345-347; Art Preis, Labor's giant step: Twenty years of the CIO (New York: Pathfinder Press, 1972), pp. 7-8.

12. Boyer and Morais, Labor's untold story, pp. 275-277.

13. Foster, American trade unionism, pp. 177-180. The three major unions that left the AFL and initially comprised the bulk of TUUL membership were the National Miners Union, the National Textile Workers Industrial Union, and the Needle Trade Workers Industrial Union.

14. Survey (November 15, 1929), pp. 195-196; "Suggestions on unemployment," [memorandum from PECE to Herbert Hoover, November 21, 1930], Harry Lurie Papers, SWHA.

15. Bremer, Depression winters, pp. 15-22. Bremer's observations of the tumultuous state of affairs in social work regarding the 1928 elections was confirmed in interviews by the author with both Celia Katz (May 15, 1981) and Julia Barnes (January 14, 1981).

16. Fisher, The rank and file movement in social work, p. 7.

17. Bremer, Depression winters, pp. 68-69; Reynolds, An uncharted journey, pp. 142-143.

18. Interview by author with Margaret Wheeler, September 19, 1979.

19. Proceedings of the National Conference of Social Work, 1931 (Chicago: University of Chicago Press, 1931); Proceedings of the National Conference of Social Work, 1932 (Chicago, University of Chicago Press, 1932).

20. William Hodson, "The social worker and politics," Proceedings of the National Conference of Social Work, 1929 (Chicago: University of Chicago Press, 1929), p. 106.

21. Miriam Van Waters, "Philosophical trends in modern social work," Proceedings of the National Conference of Social Work, 1930 (Chicago: University of Chicago Press, 1930), p. 15. 
22. Gertrude Springer, "The fighting spirit in hard times," Survey 68 (June 15, 1932), p. 271.

23. Ibid., p. 269.

24. William Hodson, "The effects of the Depression on professional standards," Proceedings of the National Conference of Social Work, 1932 (Chicago: University of Chicago Press, 1932), pp. 533-536.

25. Mary van Kleeck, "Social planning and social work," Proceedings of the National Conference of Social Work, 1932 (Chicago: University of Chicago Press, 1932), p. 299.

26. Springer, "The fighting spirit in hard times," Survey, p. 265.

27. Fisher, The response of social work to the Depression, p. 93.

28. Fisher, The rank and file movement in social work, pp. 7-8.

29. "Directory of rank and file organizations," SWT (January 1935), p. 31.

30. Social Workers Discussion Club, The social workers discussion club [Pamphlet] (Fall, 1933), Jacob Fisher Papers, Box 1, Folder 1, SWHA.

31. Ibid.

32. Interview by author with Eleanor Cohen, February 12, 1994. Cohen was a member of the Chicago discussion club and a member of the Social Workers Association of Cook County, which represented workers in the Cook County Bureau of Public Welfare.

In regard to the question of Communist Party involvement in the discussion clubs, Fisher indicates that at least in the New York club, "few" were members of the Party (The response of social work to the Depression, p. 94). Others, such as Julia Barnes, dispute Fisher's depiction of the New York club. Barnes echoes Cohen's account of Chicago, saying Fisher's bitter break with the Party in the late 1930s led to a "distorted memory" regarding the role of the Party in the rank and file movement (interview by author, January 14, 1981).

33. Fisher, The response of social work to the Depression, p. 94.

34. Fisher, On vanishing ground, pp. 301-302. 
35. Alexander, Organizing the professional social worker, p. 76; Fisher, The response of social work to the Depression, pp. 96-97. Regarding the Harlem demonstrations, in an interview by this author with Leo Miller, a member of the discussion club, confirmed that while not an official action of the club, many club members participated upon the urging of Louise Thompson, an influential black social worker in Harlem close to the Communist Party (April 16, 1977). For further information on Thompson and the Harlem actions, see Mark Naison, Communists in Harlem during the Depression, pp. 42-43 and 50-52.

36. “An open letter to William Hodson," SWT ((July-August 1934), p. 19; "The most generous city in the world," SWT (May-June 1934), pp. 12-14.

37. “An open letter to William Hodson," SWT (July-August 1934), p. 19.

38. Ibid.

39. "Rank and file," $S W T$ (July-August 1934), p. 20; "Rank and file," $S W T$ (January 1935), p. 26; Fisher, The response of social work to the Depression, p. 97; interview by author with Eleanor Cohen (February 12, 1994); Fisher, The rank and file movement in social work, p. 8.

40. "The case for the practitioners' movement," The Compass (October 1933), pp. 45; "The practitioners' movement," The Bulletin of the Association of Federation Workers (November 1933), p. 3, Jacob Fisher Papers, SWHA, Box 1, Folder 10.

41. Ibid.; Joseph H. Levy, "New forms of organization among social workers," Proceedings of the National Conference of Social Work, 1934 (Chicago: University of Chicago Press, 1934), pp. 532-538; Fisher, The rank and file movement in social work, pp. 20-23.

42. Quoted by Fisher in, The rank and file movement in social work, p. 14.

43. "The case for the practitioners' movement," The Compass (October 1935), p. 5.

44. Ibid.

45. Fisher, The response of social work to the Depression, p. 98.

46. Irving Bernstein, The caring society: The New Deal, the worker, and the great Depression, (Boston: Houghton Mifflin Company, 1985); Watkins, The Great Depression. 
47. Leighninger, Social work: Search for identity, p. 37.

48. Interview by author with Bronislaus Zukas, October 14, 1980.

49. "Events leading up to wage crisis," The Bulletin of the Association of Federation Workers (January 1934), pp. 1-2, Jacob Fisher Papers, SWHA, Box 1, Folder 10; Fisher, The response of social work to the Depression, pp. 107.

50. Ibid.

51. "Federation embarks on new economies," The Bulletin of the Association of Federation Workers (March 1933), p. 1, Jacob Fisher Papers, SWHA, Box 1, Folder 10; "AFW: A year's review," The Bulletin of the Association of Federation Workers (March 1933), pp. 2-3, Jacob Fisher Papers, SWHA, Box 1, Folder 10; "Who are our employers?," The Bulletin of the Association of Federation Workers (December 1932), p. 4, Jacob Fisher Papers, SWHA, Box 1, Folder 10.

52. "AFW: A year's review," The Bulletin of the Association of Federation Workers (March 1933), pp. 2-3, Jacob Fisher Papers, SWHA, Box 1, Folder 10.

53. "The A.F.W. takes to action," The Bulletin of the Association of Federation Workers (March 1934), pp. 1-4, Jacob Fisher Papers, SWHA, Box 1, Folder 10. A brief history of the AFW and its subsequent concerns with professional standards can be found in Moses W. Beckelman, "A protective organization for Jewish social workers," reprint distributed by the Case-Workers Section, National Conference of Jewish Social Service (June 1933), Jacob Fisher Papers, SWHA, Box 1, Folder 2.

54. Marvin Slater, "Spying, discrimination, dismissals," SWT (May 1935), pp. 13-14; "E.H.R.B. employees point the way," The Bulletin of the Association of Federation Workers (January 1934), p. 3; "Relief workers organize," E.H.R.B. Employee (January 1934), pp. 1-3, Jacob Fisher Papers, SWHA, Box 1, Folder 9. This first issue of the Association's newsletter notes that just prior to the unionization of the HRB, workers in the state's Temporary Emergency Relief Administration organized the TERA Employees Association, successfully rolling back proposed salary cuts.

55. "Collective bargaining in New York," SWT (October 1935), p. 5.

56. "Rank and file," SWT (May-June, 1934), p. 23; "Rank and file," SWT (JulyAugust 1934), p. 20. 
57. "Directory of rank and file organizations," SWT (November 1935), p. 29.

58. The first issue of Social Work Today was published in March, 1934. The journal listed Jacob Fisher as editor and contained a list of contributing editors: Roger Baldwin; Gordon Hamilton; Eduard Lindeman; Larry Lurie; Ida de Reid; and Mary van Kleeck (SWT (March-April 1934), p. 9).

59. "Social work in America," SWT (March-April 1934), p. 2

60. Ibid.

61. Ibid.

62. Phyllis Lowell, "Social workers take counsel," SWT (March-April 1934, pp. 3-6. Quote from p. 3.

63. Ibid.

64. Ibid., p. 6 .

65. Articles in the debut issue included Charles Emmett, "The unemployed propose action," pp. 6-7; H. L. Lurie, "Wanted - $\$ 2,400,000,000$," pp. 8-9; William Gordon, "Protecting the social service employee," pp. 9-11; and Ira De Reid, "The Negro riddance act," pp. 13-14.

66. "Social Work Today," The Survey (April 1934), p. 127.

67. “Social Work Today," Social Service Review (June 1934), p. 372.

68. Fisher, The response of social work to the Depression, p. 119.

69. $S W T$ (January 1935), p. 3.

70. Ibid.

71. Complete proceedings of the first national convention of rank and file groups in social work, Pittsburgh, PA February 22-24, 1935. Jacob Fisher Papers, SWHA, Box 1, Folder 3.

72. Ibid.

73. Ibid. 
74. Ibid. Reactions of delegate to Baldwin from Jacob Fisher (interview by author, February 12, 1981).

75. Complete proceedings of the first national convention of rank and file groups in social work, Pittsburgh, PA February 22-24, 1935. Jacob Fisher Papers, SWHA, Box 1, Folder 3.

76. Ibid.

77. National Coordinating Committee of Rank and File Groups in Social Work, Rank and file speak: A summary of the proceedings of the first national convention of rank and file groups in social work (New York: NCC, 1935), p. 6. Jacob Fisher Papers, SWHA, Box 1, Folder 3.

78. Ibid., p. 7.

79. Ibid., p. 6 .

80. Ibid., pp. 10-14; block quote from p. 11.

81. Ibid. Interestingly, the final resolution against racial discrimination was the only one in which a dissenting vote was cast. According to the convention minutes, a delegate from Baltimore stated she "can't approve of having white workers under colored supervisors" (Complete proceedings of the first national convention, Jacob Fisher Papers, SWHA, Box 1, Folder 3).

82. Indeed, within six months of the founding convention, the NCC reported 18 affiliated organizations in 12 cities. See: Report of the Constitutional Committee of the National Coordinating Committee of Rank and File Groups in Social Work, Jacob Fisher Papers, SWHA, Box 1, Folder 4; Fisher, The response of social work to the Depression, p. 114; Leighninger, Social work: Search for identity, p. 103.

83. "A letter to the social workers of America," SWT (July 1935), p. 4. 


\title{
CHAPTER 4:
}

\section{THE RANK AND FILE VS. THE PROFESSION}

\begin{abstract}
Professionalism: An attitude characterized by a morbid concern with the advantages which accrue from a state of suspended animation... The term professionalism describes the unwillingness of the old-time leadership of the professions to engage in any action which might bring them in line with changes in the social setting. In social work it includes opposition to union organization and to protest. $^{1}$

(Social Work Today)
\end{abstract}

As delegates to the 1934 National Conference of Social Work gathered for their annual meeting in Kansas City a mixed mood filled the air. The country was suffering through its fifth year of the economic depression, and any hopes that President Roosevelt's New Deal would bring a quick end to the crisis were now seemingly illusory. A year before, the NCSW conference in Detroit enjoyed an air of heady optimism as Harry Hopkins, one of social work's own and an architect in Roosevelt's recovery program, headlined the conference with the promise of better times. Now, while proud of their representation and influence within the administration, social workers in Kansas City were groping for a sense of direction:

The glowing enthusiasm with which they had left the Detroit meeting a year before was cold and dead. Qualified promises could no longer stir them. Dreams had been lost in confusion and they saw nothing ahead but hard reality. ${ }^{2}$

Still, the leadership of the NCSW and the AASW were loyal to the President's recovery program, and the conference agenda was replete with presentations from New Dealers such as Rexford Tugwell, Assistant Secretary of Agriculture, and one of the members of Roosevelt's New Deal brain trust, Harry Hopkins, administrator 
of the Federal Emergency Relief Administration and Aubrey Williams, assistant administrator of FERA. Indeed, just three months earlier Roosevelt had sent greetings to an AASW sponsored Conference on Governmental Objectives in which he promised "...social workers and I have the same objectives in common - social justice for everyone." ${ }^{3}$ Accordingly, the conference planning committee and NCSW President William Hodson, a close colleague of Hopkins and director of the New York City Home Relief Bureau, had crafted the conference to buttress the profession's partnership with the administration's New Deal. The conference, recalled Bertha Reynolds, ...promised to be a New Deal Conference....Many social workers felt that, with our profession represented in the cabinet by Harry Hopkins and Frances Perkins, we had arrived and could give leadership in welfare matters which had hitherto been denied to us. $^{4}$

And as the conference got underway Tugwell invoked the New Deal spirit, calling on social workers to continue their support of the administration, even if the expected outcomes were now more limited:

I would see you enlisted as soldiers not in a new cause but in an old one. I would ask your loyalty not to a new faith but to an old one which is struggling to return to a lost democracy; it is trying to do it through a discipline of groups which opposes the individual...The most you can do for people is to discipline the institutions and forces which are inimical to the individual and so to provide freedom of action. You cannot forever go on providing subsistence for the idle at government expense. ${ }^{5}$

But neither Tugwell, Hopkins or the conference planners were prepared for the events of the following day. 
Once again, Mary van Kleeck would challenge the profession in a presentation, entitled "Our Illusions Regarding Government." Interest in van Kleeck and her presentation had been building up prior to and during the conference. In 1933, van Kleeck had startled the profession when she responded to her appointment on the President's Advisory Council of the United States Labor Service by resigning at its first meeting, citing her opposition to what she considered the anti-union character of the National Recovery Administration (NRA). From her position as chair of the subcommittee on labor policy for the American Civil Liberties Union, van Kleeck had also recently written Roosevelt on behalf of the organization expressing its opposition to the NRA. In addition to her criticism of the NRA, van Kleeck's outspoken support for the rank and file movement was well know within the profession, as was her even more controversial and frank admiration of the Soviet Union and its national planning system. Following a visit to the Soviet Union in 1932, van Kleeck had published glowing reports on Soviet national planning efforts in professional journals and in the pages of Soviet Russia Today, drawing the ire of many in the profession's leadership. ${ }^{6}$

The backdrop of interest in van Kleeck's presentation was intensified the second morning of the conference. The day before, van Kleeck had addressed a meeting of the Urban League, and morning newspapers contained reports of her admonition to the League that its middle-class composition could not provide leadership to the masses of black workers. ${ }^{7}$ As the conference session now got underway a correspondent from Survey noted the degree of anticipation: 
Everything that happened afterward at the Conference must be viewed in light of the psychology engendered at the meeting on May 22 when 1500 people jammed into a hall half designed for a third that number, blocked aisles and exits, and equally endangered themselves in their determination to hear Miss van Kleeck discuss Our Illusions Regarding Government. ${ }^{8}$

van Kleeck did not disappoint the audience, focusing her remarks on what she considered two prevailing theories regarding the form of government. van Kleeck described the first theory as a mistaken belief that the state was a benign institution apart from transitory conflicting interests and ultimately reflective of democratic governance in the betterment of the public good, a theory to which van Kleeck ascribed the misguided loyalty of most social workers and which characterized the political agendas of the profession. Calling such beliefs an illusion, van Kleeck argued that, in fact, a second theory of government better described the current situation in the United States: government serves and is an instrument of the strongest economic powers in a nation. In the case of the United States, van Kleeck argued that the power of capital so dominated government functioning that the primary interest of government was the protection of the interests of big business:

The basic conflict of interest between labor and capital is too clear to need proof here. Our illusions regarding government arise out of a refusal to recognize these conflicts. They assume that the government is above the struggle and that if social workers can win the government to their program they will have done their part in establishing that elusive thing we call 'social justice."

As van Kleeck expounded on her thesis that the inadequacy of New Deal relief programs represented the administration's collusion with business over the interests 
of workers, she concluded with an attack on the profession's close alliance with the Roosevelt administration:

Social workers are accepting important positions in various branches of government in this country. Those of you who believe that that is the way you can best serve must look well to the significance of mass protests which are disturbing your working hours. Will social workers continue to bear the brunt of these protests against politicians in alliance with the property interests...or will social workers rather look upon themselves as spokesmen for these protests...A clearer view will inevitably lead to some refusals to take governmental positions if these demand, as many do, that social workers...will work as apologists for the government of the day.

...social workers need alignment with other workers, not drawing their inspiration from the relation of social worker to client, but rather identifying themselves as fellow-workers...not tempered to the 'temper' of the administration and Congress but to the needs of the working people, whose standards of living should be the primary and indeed sole concern of all branches of social work. ${ }^{10}$

The audience response to van Kleeck was, according to Survey correspondent

Gertrude Springer, "electric":

The younger and more volatile rose as to a trumpet-call. The soberest were shaken. Even the numbers who only faintly knew what it was all about reacted in a way that can only be described as a shot in the arm. From that moment a good part of the Conference threw its earlier concerns to the winds and went off in full cry behind leaders of one gospel or another. ${ }^{11}$

Reaction from the conference organizers was swift. The following day, Conference President William Hodson, in an act unprecedented in NCSW history, issued a public rebuke of van Kleeck's assault upon the New Deal. Objecting to van Kleeck's call for delegates to "repudiate" the Roosevelt administration, Hodson made his position clear, "I, for one, am still willing to throw my lot with the present 
national administration, reserving always the right to differ and to criticize as a friend and not as an enemy." "12 Harry Hopkins also responded to van Kleeck's speech, declaring "We who serve the government have no apologies to make," and, in response to a question regarding what political strategies the profession should engage in declared, "Before becoming very convinced of the brand of political action to adopt we need group study and discussion."13

Under the leadership of van Kleeck, rank and file social workers vied for ideological domination of the conference. Buoyed by their recent successes in organizing unions in public relief agencies, they made their presence known in plenary sessions and ad-hoc meetings. Following Hodson's condemnation of van Kleeck, rank and file delegates organized a rump session attended by nearly 1,000 conference delegates voting to censure Hodson. They again turned out in force when van Kleeck responded to Hodson in a second speech, "Common Goals of Social Work and Labor." In a final session on the impact of the NRA, van Kleeck held the floor alone as her two co-presenters, John Frey of the AFL and Frances Haas of the National Labor Board failed to appear. Reiterating her opposition to the NRA, van Kleeck warned her audience that the nature of the NRA represented a "...corporationcontrolled form of labor organization under the Fascism which has been evolving within the framework of the New Deal."14

The controversies so apparent at the Kansas City NCSW served to clearly demarcate the growing differences between the programs and philosophies of the rank and file movement and those of the mainstream of the profession. These 
differences would constitute sharply diverging views regarding both the New Deal and the form and function of the profession. The rank and file's emphasis on unionization and identification with the industrial workers movement would place it far to the left of the mainstream profession in its initial opposition to the New Deal and its active support of left and progressive causes over the next decade. The labor orientation of the movement would similarly challenge the traditionally professional and politically neutral definition of social work that many in the movement saw as representative of the AASW and much of the profession's leadership.

\section{The Rank and File in the New Deal}

The left progressive political analysis that informed the participants of the early discussion clubs moved with them into the emerging rank and file movement of the early 1930s and the unions in which they often assumed leadership. Guided by the radical politics of the movement's mentors such as Roger Baldwin and Mary van Kleeck, and nurtured in the close alliance of the unions with left leaning organizations of the unemployed, a burgeoning peace movement and more radical expressions of the civil rights movement, the initial response of the rank and file movement to the New Deal was decidedly hostile.

Mary van Kleeck's warning to social workers at the 1934 NCSW conference on the collusion between business and the government exemplified the general tenor of the rank and file movement's early reactions to the programs of the New Deal. While initially supporting federal responsibility for relief efforts, rank and file leaders soon characterized what they considered the meager programs of the New 
Deal as evidence of a growing trend towards social fascism in the United States. The pages of Social Work Today in 1934 and 1935 were replete with articles by the movement's leaders warning social workers of the dangers of this creeping fascism as represented in the NRA, military control of the Civilian Conservation Corps (CCC) and the administration's reluctance to embrace the right of workers to collectively bargain. ${ }^{15}$ In Social Work Today's second issue, editor Jacob Fisher summarized the movement's position:

As big industry moves into closer alliance with the state to retain its strangle hold upon the nation, liberalism translates its historic belief in man as a free agent into contemporary terms and demands the end of laissez-faire, playing into the hands of big industry. Behind the call for the abundant life the slow fascization of American economic life matures and takes hold...We are today in a period of declining capitalism and fascism fits the mood better. Creature of a middle-class that espoused liberalism...and will turn to fascism tomorrow, social work cannot escape the fundamental realignments that society is undergoing today. ${ }^{16}$

Echoing Fisher, Eduard Lindeman also warned the journal's readers that the choices before them were stark:

For our period of history the two major polarizations are Communism on the one hand and Fascism on the other. The Fascist pattern is dominated wherever it appears by the open dictatorship of big industry which finds it necessary to take over the apparatus of the state to strengthen its hold on a shaky social and economic structure. And since Fascism represents in essence only another phase of capitalism [unemployment] continues in all its severity. ${ }^{17}$

The warnings of van Kleeck, Fisher and Lindeman concerning the threat of fascism inherent within the New Deal closely mirrored the position of the Communist Party during its so-called "third period," raising early questions among 
some in the AASW that the movement was in the "Communist camp." 18 Such concerns had some merit. In fact, the origins of what would be referred to as the social fascist theories of the early 1930 s were directly traced from the Comintern's Tenth Plenum held in Moscow in 1929. Proclaiming that the revolutionary movement had passed through a period of revolutionary upsurge between 1917 1924 , followed by a second period of capitalism's temporary stabilization, the Comintern now determined that a third period had emerged. This new period marked the worldwide economic crisis of capitalism that would, in the Comintern's estimation, led to both capitalism's increasing tendency towards fascism and antiimperialist revolution among the working class. Declaring the theories of social democracy as supported by the Socialist Party and liberal bourgeois democracy a disguised form of fascism, the Comintern directed communist parties to prioritize attacks on this new form of social fascism. ${ }^{19}$

As the American Communist Party declared a period of "class against class" in 1929, it condemned the Socialist Party and the AFL leadership as enemies of the working class, established the TUUL to lead opposition to the AFL, and attacked Socialist Party leader Norman Thomas as the leading "social fascist" in the country. ${ }^{20}$ With the election of Franklin Roosevelt in 1932, the party applied its theory of social fascism to the New Deal, as party leader Earl Browder declared:

It is clear that that fascism already finds much of its work done in America, and more of this is being done by Roosevelt...In the labor sections of the New Deal program [are] to be seen the clearest examples of the tendencies to fascism...For the working class, the Industrial Recovery Act is truly an industrial slavery act. It is one 
of the steps towards the militarization of labor. It is the forerunner of American fascism. ${ }^{21}$

The apparent alignment of the rank and file movement's criticisms of the

New Deal with the pronouncements of the Communist Party was more than

rhetorical. Mary van Kleeck's association with the TUUL and the presence of party

members in the rank and file unions clearly predisposed the movement towards at

least partial agreement with the Communist's political platform. As rank and file

activist and Communist Party member Margaret Levy recalls,

The rank and file weren't a product of the party, but certainly many in the unions and in Social Work Today were members or close to us. The Communist's provided the clearest explanation of why capitalism was failing and why Roosevelt, Hopkins and all that crew couldn't lead us out of the Depression. Those of us who were members obviously supported the party's line, but we didn't dominate or control the movement. You need to remember that what we were saying wasn't considered by everyone as unreasonable or the ravings of a group of crazies. Lots of people came to similar conclusions independent of us. ${ }^{22}$

Indeed, the political landscape of the both the rank and file movement and the American left during the 1930 s reflected the convergence of many tendencies that reflected to various degrees agreement with the political line of the Communist Party. But these tendencies reflected not only the analysis of the Communist's, but as well those of the Socialist Party and numerous other organizations that were anarchist or Trotskyist in orientation. Nor were the Communists, Socialists or the social work rank and file the only ones who had become disenchanted with the New Deal by late 1933 and early 1934. Even liberal, non-Communist journals such as The Nation, New Republic and Common Sense which had hailed the election of 
Roosevelt and the implementation of the New Deal, became increasingly critical of Roosevelt's failures. The editors of The Nation expressed their disappointment that the administration's attempts to kick-start industry was being done at the expense of workers, employing little more than a strategy of "...trickle down from the top" and achieving little fundamental change in the economic arrangements that brought about the Depression. ${ }^{23}$ In a similar vein, the New Republic expressed its concern with the mixed results of the New Deal, criticizing Roosevelt for trying to mediate in the conflict between labor and capital rather than taking the side of one or the other. ${ }^{24}$ But unlike these liberal journals, Social Work Today was noted in particular for its close agreement with the Communist Party's pronouncements, a fact not lost upon the profession's leadership. ${ }^{25}$

Besides sharing a fear of creeping fascism within the programs of the New Deal, the rank and file movement and the Communist Party were equally allied in their calls for passage of national unemployment insurance. The legislative centerpiece of the Communist Party was the Worker's Unemployment and Social Insurance Bill, introduced in Congress by Minnesota Representative Ernest Lundeen in early 1934. Drafted by the Communist Party with the assistance of Mary van Kleeck, the "Lundeen Bill," as it was popularly referred to, was strongly supported by the Communist Party, the National Unemployment Council, the Workers Alliance and a broad coalition of unions and progressive organizations. ${ }^{26}$ Reintroduced in 1935, the Lundeen Bill called for the establishment of unemployment insurance “...for all workers and farmers...unemployed through no fault of their own," to be 
administered by and controlled by "...unemployment insurance commissions directly elected by members of worker's and farmer's organizations." ${ }^{27}$ The bill also authorized the development of social insurance plans for those unable to work because of "...sickness, old age, maternity, industrial injury, or any other disability. ${ }^{, 28}$

Social Work Today and rank and file social work unions lined up in support of the Lundeen Bill in 1934 and 1935, passing resolutions calling for its passage by Congress. To publicly demonstrate support, eleven social work unions and discussion clubs sent delegates to the national Congress for Unemployment and Social Insurance held in New York City in January, 1935. The Congress, called by the NUC, attracted an audience of over 3,000, representing unemployed councils, unions and other organizations in forty states calling for enactment of the Lundeen bill. Among the speakers greeting delegates were Communist Party leader Earl Browder, T. Arnold Hill of the National Urban League, Representative Ernest Lundeen and Mary van Kleeck. ${ }^{29}$ As the conference met to outline the demands of the unemployed, rank and file social workers, including Jacob Fisher, were appointed by the convention to be part of a delegation sent to meet with FERA officials. After being informed that Harry Hopkins was ill, the delegates met with FERA Assistant Administrator, Aubrey Williams. An article in Social Work Today captured some of what transpired:

One by one elected spokesmen step forward to voice the demands of their group. A representative of the Public Relief Investigators Association of Minneapolis, sent to Washington to convey to the 
Congress and to the Administration their support of the Workers Bill. Another relief worker from Philadelphia, who reads a set of fifteen resolutions adopted by a caucus of workers in public and private social agencies...demanded recognition of the right to organize, rank and file control of work projects, adequate wages, a socially useful works program, the cessation of the use of force against the unemployed, the enactment of the Workers Bill. Another relief worker, this time a Negro from the Home Relief Bureau in New York, protesting racial differentials in relief, distribution of jobs and wages....

If Williams is struck with the appearance of staff members of relief agencies on the delegation he doesn't show it. He is in fact a bit impatient. He asks, are you all 'our' people?...The hearing is over. The delegates leave their documents, their reports and resolutions with Williams. He piles them together, says they'll be looked into. $^{30}$

Following the Congress, delegates at the rank and file's first NCC conference formally endorsed the Lundeen Bill and prioritized its passage in the work of its constituent unions. ${ }^{31}$

The rank and file's support of the Lundeen Bill was organizationally channeled through activities of the Inter-Professional Association for Unemployment Insurance (IPA), which was primarily responsible for organizing the social work and other professional delegates who attended the Congress for Unemployment and Social Insurance. Founded in 1934, the IPA was organized by Mary van Kleeck to provide a base for professionals and their organizations to promote passage of the bill. In early 1934, van Kleeck published an open letter in the Bulletin of the Federation of Architects, Chemists, Engineers, and Technicians and Social Work Today calling for the formation of the IPA and soliciting membership. van Kleeck outlined the need for and purposes of the organization in the letter: 
The urgent need for unemployment insurance is the immediate reason for such an organization...A Professional Workers' Association such as is proposed would be composed of interested individuals, employed and unemployed, whose first tasks would be study, conference with industrial workers, and formulation of programs of action in co-operation with trade unions and organizations of the unemployed. ${ }^{32}$

Chaired by van Kleeck, the IPA included the well known psychiatrist Frankwood E. Williams as treasurer, Jacob Fisher as secretary and an executive committee composed of editor and publisher Kyle Crichton, economist Joseph Gillman, Herbert Benjamin of the National Unemployment Council, architect Percival Goodman and dramatist Elmer Rice. The IPA quickly organized some fifteen chapters throughout the country, and by the time of its first national conference boasted a membership of over 1,000. Members of the IPA were prominent in congressional hearings on the Lundeen Bill, providing testimony supporting both its constitutionality and its economic feasibility. Following the passage of the Wagner-Lewis Act, which contained the Roosevelt administration's program for unemployment and social insurance, the IPA refocused its efforts to support a broad array of progressive social and labor-related legislation by providing expert testimony before Congress by its members. But the defeat of the Lundeen Bill had effectively stripped the IPA of its primary tool for cross-profession organization, and it subsequently disbanded in $1937 . .^{33}$

The rank and file movement's strident criticism of the New Deal and its insistence on an unemployment insurance scheme, as outlined in the Lundeen Bill, greatly contributed to the deepening and contentious relationship that existed 
between the movement and the AASW. Following the chaos of the 1934 NCSW, the disagreements between the AASW and the rank and file intensified as the AASW Committee to Outline a National Social Welfare Program met in the fall. Charged by the AASW with developing “....general social principles considered as basic in planning a national social welfare program," the committee quickly splintered as it members argued over the merits of a "maximum" program put forth by committee chair Harry Lurie and Mary van Kleeck and a "minimum" program supported by the majority of the committee, including AASW president Dorothy Kahn, Grace Abbott, Ewan Clague and Linton Swift, executive director of the Family Welfare Association. ${ }^{34}$ The maximum program of van Kleeck and Lurie called for the development of a national program of social insurance based on "mass need" as opposed to individual insurance. ${ }^{35}$ Based on the principles of the Lundeen Bill, van Kleeck and Lurie advocated a national insurance program that would cover “....all unemployment, whatever the cause - industrial changes, occupational accidents, sickness, maternity, or old age. ${ }^{36}$ To fund the program, Lurie and van Kleeck advocated the use of income taxes, “...thus demanding at once a redistribution of national income to the extent that continued unemployment requires divergence of funds from higher incomes to compensate for loss of wages. ${ }^{\text {"37 }}$ While calling for a national program of public works, van Kleeck and Lurie cautioned that to date such programs had been directed primarily towards "unproductive tasks" by the Roosevelt administration. ${ }^{38}$ To remedy this they argued that a planned economy must be put in place: 
A national social welfare program must of course face the fact that proposals for social insurance at this time cannot hope to do more than compensate for unemployment. They cannon constitute 'employment insurance' nor establish economic security. Security which would eliminate the hazards of fluctuations in business traceable to the anarchy of production under private ownership can be established only by the substitution of social economic planning for the ownership which by its results has proved its inability to maintain security. ${ }^{39}$

In contrast to the proposals of Lurie and van Kleeck, the minimum program supported by the rest of the committee outlined a proposal resembling the prevailing relief programs of the administration. Calling for a federal "Department of Public Welfare," proponents of the minimum program recommended the government continue through this new department to provide grants to states which would administer and provide relief, develop standards of eligibility and require "trained personnel" to administer relief programs. ${ }^{40}$ The minimum program recommended that unemployment compensation be set below actual wages on the job and that relief be provided only on the basis of demonstrated need: “....advocates of this view hold that the primary responsibility for taking care of his needs shall, however, remain with the individual and his immediate family with public responsibility to be considered as secondary and supplementary. ${ }^{, 41}$

As Lurie drafted the report of the Committee to submit to the AASW's Division of Government and Social Work, open dissension within the committee erupted in a series of communications between committee members. Ewan Clague expressed concern that the stance of Lurie and van Kleeck called for socialism, and other supporters of the minimum program believed the report should emphasize 
public welfare programs, not systems of social insurance. Calling the maximum program "the impossible program," AASW President Dorothy Kahn labeled Lurie's report "biased," and after consultation with Kahn, Grace Abbott, Linton Swift and other members of the committee, AASW Executive Secretary Walter West responded on January 26,1935 to Lurie's report, declaring:

there is ample evidence that this document does not represent the considered views of your Committee...it seems to me that the problem which your statement has raised for the Conference management and for the chapters is one which involves a totally different approach to that which we have to consider with current programs...

Three days later, the Steering Committee of the Division on Government and Social Work voted to not accept Lurie's summary of the two programs and agreed that separate memos from the differing camps would be sent to chapters prior to a planned conference to take up the report. However, as the conference date approached, the steering committee reversed course, deciding to withhold publication or distribution of the draft reports. ${ }^{43}$

As Lurie and van Kleeck complained of censorship by the AASW, rumors of a dispute between a left and right wing in the committee circulated among AASW chapters prior to the March conference. On the morning that the conference got underway, AASW officials finally agreed to the release of Lurie's report. ${ }^{44}$ Lurie outlined the differences between the maximum and minimum programs to conference delegates and a debate ensued. Declaring the minimum program a "glorified poor law," Lurie and van Kleeck defended their maximum program and 
the merits of the Lundeen Bill, while defenders of the minimum program argued its reasoned improvements within the framework of the current relief system. ${ }^{45}$

Following two days of discussion, Social Work Today reported that the conference ended in confusion as final revisions to the conference report, now supporting the minimum program were debated and voted upon:

'We regard as a great social advance,' says the report, 'the acceptance by the present federal administration of the principle of governmental responsibility for economic security.' Immediately there is objection from the floor...The statement is amended to convey the deep disappointment of many delegates with the inadequacy of the proposal to meet the vital needs of the unemployed. The resolution declaring against discrimination in employment practices also fails to appear. Some one makes a point of it and it goes into the Report...In discussing the administration's program the Report stated that 'a majority' of those present regarded it as a great social advance, whereas no actual report had been taken and the word used at the meeting had been "some." "46

Tensions between the AASW and the rank and file movement continued to deepen as the Roosevelt administration announced plans in 1935 to reduce federal commitments to direct relief with the termination of FERA and the further development of work relief programs in the Works Progress Administration. As the AASW considered calling a national delegate conference to advocate for the continuation of direct relief, concerns mounted over the possible influence of the rank and file on the conference, particularly in light of the Kansas City NCSW. While rank and file unions joined protests of unemployed councils and were well represented at the Congress for Unemployment and Social Insurance, the AASW sought a more moderate course. Internal debate over the nature and purpose of the 
conference reflected the association's fear of the rank and file, as Grace Marcus urged the AASW to restrict the rank and file's possible influence: "I don't think that group should be given the floor or allowed to speak so much this year." ${ }^{, 47}$

The reverberations of the 1934 NCSW conference and the first national rank and file conference also continued to color the relationship between the mainstream of the profession and the movement. Survey solicited and published a sharp rejoinder to Mary van Kleeck's remarks at the conference. Entitled "Illusions Regarding Revolution," the article warned readers of the danger's represented by van Kleeck and the rank and file:

The greatest danger that lies ahead of us is the danger that the American people may become confused in the fog of conservative and radical propaganda, may mistake the location of the battle-line, and fighting over irrelevant issues may wake up to find the New Deal a vanished dream...

...there is a certain danger in listening to the prophets who dream of far-off things that you cannot do anything about...If you can believe that nothing is happening now and that the real struggle is still in the future, then you can draw aside and retreat into the dream world where Communism makes faces at the wicked capitalist...The battle is not between the New Deal and the Communist State. ${ }^{48}$

The profession's leaders also increased their counterattack against the growing influence of the rank and file. AASW President Dorothy Kahn decried the movement's assaults upon the profession, declaring that "The outstanding fact of this year in social work is the attacks on social workers and their clientele, on professional standards from without and - I regret to say - from within. ${ }^{, 49}$ Porter 
Lee also weighed in, expressing his disagreement with social workers who entered the political arena:

There may be social workers who are expert on taxation, on collectivism, on constitutional law, on the proposal to make the production and distribution of milk a public utility - but they did not become expert in these matters as a result of their training and experience as social workers. Unless he has had other training I do not see how any social worker could assume the role of leader or advocate in these legitimate fields of social action without risk both to these programs and to the status of social work. ${ }^{50}$

Indeed, the concerns of the AASW were not without merit. Following the formation of the rank and file's National Coordinating Committee at its 1935 conference, NCC chair Jacob Fisher boasted of the movement's growing power, directly challenging the continued role of the AASW as the profession's representative:

[The rank and file's] combined strength is formidable and is growing every day. The Pittsburgh convention proved among other things that the rank and file movement is by way of losing its character as a minority movement. The total membership represented by official delegates was over 8,200 , which is close enough to the 8,600 figure of the American Association of Social Workers to suggest that within a very short space of time the new groups may soon be able to challenge effectively the A.A.S.W.'s claim to speak for the whole of social work. ${ }^{51}$

Following their successes at the 1934 NCSW, the rank and file once again made their presence known at the 1935 NCSW in Montreal. This time the NCC developed a program of workshop sessions, sponsored a booth for Social Work Today (over which the NCC had assumed control following the Pittsburgh conference), and published a daily "Rank and File Bulletin" for distribution at the conference. ${ }^{52}$ Despite the increasingly hostile rhetoric of the AASW, NCSW 
Conference President Katherine Lenroot (Chief of the Children's Bureau) struck a more conciliatory tone towards the rank and file, noting their accomplishments while omitting any reference to their union character:

One of the most significant developments of social work in the last two years has been the 'rank and file movement,' which is well represented at this Conference. Young people in direct daily contact with those served by social work are developing through practitioners' groups and discussion clubs challenging and vigorous points of view and programs, and are emphasizing association with other groups. ${ }^{53}$

The NCC sponsored program at the conference reflected the broad array of issues and causes espoused by the movement, including presentations on "The Negro in Social Work," "Mental Hygiene in a Changing World," "Casework - A Realistic Approach," and "Social Work and Fascism." Nearly 1,000 delegates attended presentations by Mary van Kleeck and Herbert Benjamin on the relationship between the unemployment movement and social work, where once again van Kleeck served as the ideological spokesperson for the movement. ${ }^{54}$ Calling on the profession to take a more leading role in social action, van Kleeck pointedly dismissed the profession's alliance with the New Deal:

The time has surely come to go back to the period of some years ago, when social workers were ready to voice their protests. I wish that our social work journals that have so loyally supported the present administration because of the social promises, might soon become once again journals of protest. Social workers are a fairly large group today, and with their allies and socially minded supporters their influence can be widened. We must let the people know the facts. We need a leadership of protest, not a willingness to accept political promises as genuine adoption of new principles...we must stand in defense of the civil liberties of the workers. ${ }^{55}$ 


\section{The Professional as Worker}

The growing gulf between the profession and the rank and file movement on the proper role of social work in the arena of social action reflected more than a philosophical disagreement on tactics. Rather, it equally represented profound differences regarding the very conception and definition of the social worker and the nature of professionalism. The identification of the rank and file movement with the industrial worker's movement and its emphasis on the development of a unionized worker identity differed sharply from the AASW's goals for professionalization. To leaders of the rank and file movement such as Eduard Lindeman, the identification of the social worker was inextricably linked to its realignment with the interests of the working class:

For the American professional the crux of the matter must be sought in the meaning and application of class-groupings. In the past the professional has aligned himself primarily with the privileged classes. He has thought of his profession, not as labor on behalf of the community but rather as a badge of superiority. His organizations have avoided a trade-union concern with the economic welfare of their members. They have dealt largely with the superficial aspects of so-called professional ethics and the social amenities...protective organizations in the field of social work, depart sharply form the professional association in emphasizing the identity of their interests with those of labor. ${ }^{56}$

Through the pages of Social Work Today, the rank and file's intellectual leaders attempted to articulate an alternative view of the professional social worker than that supplied by the AASW. To leaders such as Mary van Kleeck, Harry Lurie and Bertha Reynolds, the identification of social workers with the struggles of the 
working class was central to any meaningful re-conceptualization of social work

practice. For van Kleeck, social work's primary purpose and function lay in service

to the working class in both its immediate time of crisis as well as for its long term

interests:

We [social work] have the difficulty of determining our own normal function in society, because in a kind of obverse relationship we have more jobs when other workers have less. But it is a short-signed view of social work to think it functions normally only in abnormal times. On the contrary, the basic interest, even of our own group, lies also in sustaining the cultural and educational services of society...Toward that end political movements are essential; and the political movement can be most inclusive, and therefore the strongest if based upon a program of immediate needs of the majority. ${ }^{57}$

In this regard, van Kleeck believed that the full nature of social work's professional character and function would not emerge until the political movement of workers assumed political and economic control of society:

There is just one test to apply to any political movement: whether it grows out of the needs of the masses of the workers and farmers, and to what extent it aims to meet their needs; and whether its leadership is fully responsible to workers and farmers themselves...This does not mean the setting up of one group in society as superior to another group. It assumes that the basic standards of living of the people must rest on the standards of living of workers and farmers; and that the security of the people as a whole and of the middle class can be achieved in no way except through security for the producers. If professional workers can come to the realization of this basic condition of our own security; and if we in the profession of social work can take our part in bringing such a movement into action, then we shall achieve a fruitful relationship to the development of our own program in social work. ${ }^{58}$ (emphasis added) 
Lurie argued that the identification of social work with the class struggle required new forms of social casework. To Lurie, casework could no longer be content with the aims of individual "self-maintenance," "social adjustment," or "personality development." 59 Seeing such activities as primarily attempts to create "little islands of security" in the absence of just social order, Lurie suggested that casework required a practice centered on a radical "new orientation and a new structure of community life":

What is needed, in essence, is a change from a system of production and services functioning only in response to the profit motive to a system of collective social life in which the resources of a community, material and cultural, are to be used by the organized community of workers and developed for their benefit and their benefit alone. It is infinitely larger than a problem in social work - it is the main social problem in this period of our history. ${ }^{60}$

Like van Kleeck, Lurie suggested that the actual functions of social workers were secondary to the central struggle for social justice and would in fact derive their more specific character out of this struggle:

To have a part in the solution of the problem, therefore, means for the individual the necessity of adding to his functions as an employed professional worker the function of a socially conscious worker who, in alignment with other workers, seeks for a practical approach to these current problems. This will require identification with a workers' movement, an organization of individual workers of all ranks and vocations seeking through political and economic means to place the whole of our common life under democratic control. ${ }^{61}$

Drawing upon her psychoanalytic training and attempting to integrate Marxist theory, Bertha Reynolds argued that social casework found its function in dealing 
with "the relationship between individuals or groups and their physical or social environment" (emphasis in original). ${ }^{62}$ In this regard, Reynolds believed that social casework could only apply such a model in the presence of a healthy social order: "If the social order is so sick that resources for subsistence, health, work and the development of personality are not there, social case work can never supply them in any adequate quantity or in any healthy way. ${ }^{, 63}$ To Reynolds, social work had not been yet been able to develop a full sense of casework practice based on relationship due its origins within an unhealthy society, and thus did not know “...what its possibilities might be in a sound social economy." ${ }^{, 64}$ Like Lurie and van Kleeck, Reynolds' felt the only resolution to the profession's contradictions lay in its participation in the greater struggle for human and economic rights, applying what special skills and knowledge it had to that struggle:

With patient and determined study we shall find some principles to guide us. Perhaps we shall find others who share these principles, and we must not let non-essentials divide us from them, for in an interdependent world disunion spells death...I doubt whether it matters much whether we say we participate as human beings or as social workers. Our profession has made us different from what we would have been as actors or butchers, and we can not slip it off as a garment when we take part in vital matters. It may be that because we are social workers we shall bring to a blind struggle a bit more of clarity, and because we know people well we may relate ourselves to others more constructively, even in the midst of destructive forces. ${ }^{65}$

\section{Social Work and the Tactics of Labor}

While the rank and file's hazy conceptions of an alternative form of social work practice paled beside the profession's established principles of social casework, 
their application of labor tactics to the field was both more explicit and more threatening to mainstream social workers and the AASW. As organizing efforts in public relief agencies intensified in late 1934 and through 1935, so did the militancy of their tactics in the face of increased resistance from agency administrators and retractions in federal relief efforts. Tensions mounted as both public and private agencies discharged increasing numbers of union leaders and activists for various reasons of inefficiency and insubordination. In this regard, the case of Sidonia Dawson would be an early incident illustrative of the severely strained relationships that formed between the rank and file unions and the AASW.

In October 1934 Sidonia Dawson, a supervisory aid at the New York Emergency Home Relief Bureau, was dismissed on charges of insubordination after she protested the use of police by the HRB to breakup a demonstration by members of the New York Unemployment Council. During the course of the police action several protestors were injured and required medical attention. The following day flyers protesting the police action appeared in the HRB office, attributed by the HRB management to Dawson, head of the union's local grievance committee. Later that day Dawson participated in a mass demonstration outside the office where she addressed the crowd and accused the HRB of engaging in racial discrimination in relief practices and of tolerating police brutality. After meeting with HRB administrators, Dawson was fired as HRB officials informed Dawson that her “...activities both inside and outside of the precinct office during the past week have indicated that it is no longer desirable to have you remain on the staff.",66 
The EHRB Employees Association demanded the immediate reinstatement of Dawson, publishing an open letter in the New York Post protesting the dismissal. In the letter, the EHRB Employees Association accused the HRB of tolerating police brutality in relief offices and Public Welfare commissioner William Hodson of seeking to deprive HRB employees from "...exercising their constitutionally guaranteed civil liberties [including] free speech, press, and the right of assemblage." ${ }^{67}$ Hodson responded with an accusation that "...a small number of left-leaning employees in the HRB" were attempting to wrest administrative control of the HRB, and issued an order forbidding HRB staff from discussing their work or the work of the HRB with any newspaper or broadcast media. ${ }^{68}$ Following the exchange, the EHRB Employees Association held a public trial, in which union leaders accused the HRB of promulgating policies “...that keep clients ill and freezing in slum buildings...[and starting] a campaign of dismissals, punitive transfers and petty persecution of prominent members of the Association. ${ }^{.69}$ Union officials also produced copies of personnel files on Dawson and other HRB employees who had been dismissed. Dawson's file included a detailed record of her union activities, an anonymous note that charged with her with being "...red of the deepest red," and a memo from her supervisor to the director of the HRB stating “...she has been known as a red.",

As publicity over the Dawson case continued, the local AASW chapter agreed to investigate the circumstances of Dawson's firing and the working conditions in the HRB upon the request of the local practitioner group. In its 
findings, the AASW report made no recommendations regarding the disposition of Dawson's case but commented that “...divided loyalty and mental conflict must inevitably endanger the esprit de corps and unity of objectives between executives and staff essential for good services to clients." ${ }^{\text {"71 }}$ While the report objected to the use of police in the HRB office and recommended the HRB improve its working relationship with employees, the report also condemned the union for its "revolutionary tactics" and "disruption to hasten the revolutionary order.",72 Agreeing with union complaints that the physical condition of the HRB offices were "miserable," the report went on to object to "disruptive" protests as a legitimate means to resolve problems: “...we can only state that social work and lay opinion must be effectively mobilized to relieve these intolerable conditions." ${ }^{, 73}$ Rank and file confidence in the AASW in the wake of its decidedly mixed findings was further eroded by comments on the Dawson incident published in Survey. While supporting the need for hearings before dismissal, an article describing the incident appeared to echo the findings of the AASW committee:

We have noticed that in the case under discussion the worker involved did not use established intra-mural procedures to state her protest...but adopted instead certain provocative tactics embarrassing to the administration...we realize that the right of self-expression and the form it may take are a proper concern of administration. ${ }^{74}$

The Dawson firing was one of many dismissals that plagued union organizing efforts. In December 1934 Bernard Riback, President of the New York Home Relief Bureau Employees Association, was fired for "insubordination and inefficiency," 
including the allegation that he over-stayed a lunch break. ${ }^{75}$ Like the case of Sidonia Dawson, Riback was fired after he attempted to intervene in an incident in which police officers were struggling with unemployed demonstrators. In response, members of the union staged a protest attended by 2,000 employees and members of local unemployment councils. ${ }^{76}$ In Chicago, Frank Kornacker, chairman of the Chicago Federation of Social Service Employes was fired from the Chicago Unemployment Relief Service for alleged "slumping" in his work, and another union leader was fired shortly thereafter on charges of distributing leaflets protesting the firing during work hours. ${ }^{77}$ In New Jersey, the Essex County Emergency Relief Administration fired the president of the Newark Relief Workers Association and the union's newsletter editor following union protests of announced budget cuts. Within two months two more workers were fired for "insubordination in regard to budget control" in response to orders to cut family relief budgets. Both workers, leading members of the Newark Relief Workers Association, were accused not of disobeying orders, but, in the words of the agency, “...an attitude of defiance [in which] they held a constant threat of client riots over the heads of their supervisor. They disrupted the whole morale of the office. ${ }^{\text {78 }}$ As firings of additional union officials and activists continued in the Essex County office, the agency director denied any anti-union purge, stating that given the firing of the union president "...chances for the organization's growth are much greater now that it could look to a more constructive leadership." ${ }^{, 79}$ Similar dismissals of union leaders and activists for insubordination and communist sympathies were reported in the pages of Social 
Work Today in Baltimore, Kansas City, Los Angeles, Minneapolis, Philadelphia, Cleveland and St. Louis. ${ }^{80}$ Noting the dismissals of Dawson, Riback and others, Social Work Today complained :

The discharges...are the latest of a series of firings through which relief officials hope to crush opposition to their destructive policies. Further intimidation may be anticipated with the progressive development of the crisis. The problem is not local. It is national in scope. ${ }^{81}$

The firings of union officers and activists and other forms of harassment pushed unions to intensify their use of militant tactics. In New York City, the Home Relief Bureau Employee's Association accused the HRB administration of a concerted campaign to break the union by the use of arbitrary firings of union officers, surveillance of union activities and discriminatory treatment of union employees. The union formed a Joint Committee of rank and file unions to investigate their charges and submit a public report. In April, the Joint Committee publicly released their report at a meeting attended by HRB employees and administrative staff. The report supported the charges of the union that the HRB had conducted a campaign of discrimination against the union and called for the reinstatement of four union officials fired for "inefficiency and insubordination.",82 In addition the committee called for the end of police presence in HRB offices, discriminatory treatment of union members in job assignments and evaluations, and a system in which the committee alleged the HRB forced some employees to spy upon the activities of union co-workers. ${ }^{83}$ 
The relationship between the HRB and the union, now renamed the Association of Workers in Public Relief Agencies, continued to worsen, finally reaching a head in October of 1935. In September the HRB announced that due to contractions in federal relief funds some 900 employees would be discharged in November, the first of what they estimated would be a total of 3,000 layoffs. On October 24, over half of the 15,000 employees of the Bureau staged a mass walk-out and held a protest rally at Madison Square Garden. Under the slogan "We Need Our Jobs, Our Jobs Need Us!," the demonstration drew an audience of over 15,000, including HRB employees, members of local unemployment councils, representatives of 60 unions, and members of the public. Following the walk-out and rally, the HRB announced it would rescind all but 1,200 of the 3,000 planned dismissals. Most of the 1,200 not re-hired were subsequently transferred in to the work projects of the WPA. ${ }^{84}$

The New York City unions were not the only rank and file unions to engage in strikes and walk-outs, extending their efforts to organizing workers in WPA workrelief projects. In April, 1935, under the leadership of the local rank and file union, over 5,000 relief workers went out on strike in Rochester, New York to protest inadequate salaries. Other walk-outs over salary and working conditions were also conducted in 1935 by WPA workers with the assistance of rank and file unions in Pennsylvania, Ohio and Chicago. Organizing was more difficult in some cities such as Kansas City, where relief administrators put a letter in paychecks of workers advising them that "inciting discord among the employed [WPA] men" would bring 
dismissal, and informed WPA workers that "...if you are discharged from your work, for just cause, you cannot go back on the relief rolls." 85

The use of walk-outs, strikes and other labor tactics by the rank and file in New York and elsewhere raised concerns among leaders of the profession, particularly within the AASW. In opposition to the AASW's attempt to develop a professional image and program, the tactics of the rank and file were seen by some in the AASW as threatening its emphasis on moderation and professional decorum. While believing that social workers could appropriately organize themselves into "efficient, coordinated groups," Ewan Clague warned social workers that the use of labor tactics were inadvisable due to the unique relationship that existed between the profession and the administration:

In dealing with the Government it is impossible to use the more aggressive tactics that are used on a private employer...such action against the Government is always interpreted as being directed against the public as a whole. Any politician can cry 'subversive,' 'revolutionary,' 'communistic,' and easily persuade the public that concerted action by a group of Government employees is a threat to the general welfare."86

Clague extended his opposition to the use of labor tactics to private charities as well, arguing that "...the worker in a private agency cannot avoid having some concern about the prospects for raising the agency's budget in the annual community appeal." $" 87$ Instead, Clague urged social workers to maintain a professional demeanor when faced with conflict and, consistent with the stance of the AASW, to at all times ensure a maintenance of professional standards. 
Joining Clague, John Fitch, a respected faculty member at the New York

School of Social Work, spoke for many in the mainstream profession who opposed

the tactics and programs of the rank and file, particularly the use of strikes:

...there is a difference between social workers and industrial workers that makes inappropriate for the former what might be good tactics for the latter. Social workers have a professional responsibility that iron molders do not have. Social workers are entitled to decent working conditions and decent remuneration...However, they did not enter social work solely, or even primarily, to make a living...the strike weapon is not an appropriate weapon for the social worker. Ordinarily, a strike would do so much damage to the accomplishment of the higher purposes which his work contemplates that I think it would be better for him to change his occupation rather than jeopardize those higher purposes. ${ }^{88}$

Even more liberal social workers, such as Survey editor Paul Kellogg, questioned the degree of militancy employed by the rank and file. While strongly supporting the right of social workers to organize and engage in demonstrations, picketing, work stoppages and strikes, Kellogg questioned the motives and ethics of the rank and file:

...when it comes to policy-making it is up to those who participate to ask themselves what it is, collectively, they want to get through their organization - no less than how to go about it. The choices before them range all the way from personal security in the job to unsettling the economic order. There is a whale of a lot of difference between tactics used to better relief and the same tactics used to break down a relief administration as part of a general agitation. Social workers face also the distinction between an ordinary industrial dispute and one where social responsibilities enter in, whether it concerns the water supply of a city, care of the sick or the help that gets to destitute families. ${ }^{89}$

The debate over the proper relationship of the profession with the labor movement spilled out beyond the higher echelons of the AASW into its local 
chapters. In New York, the AASW chapter, of which Harry Lurie and John Fitch were both members, debated the appropriateness of unionization in its chapter meetings of 1934 and 1935. Minutes of those meetings indicated a clear split in the membership, with one faction led by Lurie strongly advocating support of social work unions, while the other faction, represented by Fitch, questioned the ethical and practical consequences of union affiliation. Similar debates wracked chapters in California, Washington, Illinois and Indiana. ${ }^{90}$

\section{For a More Just Society}

In addition to the rank and file's emphasis on militant forms of unionism, the movement's involvement in progressive political causes would also strain its relationship with the mainstream of the profession. During the 1930 s the leaders and unions of the rank and file would actively engage themselves in the anti-Fascist and peace movements, protests of the unemployed, advocacy of the Republican cause in the Spanish Civil War and support for the black civil rights movement. ${ }^{91}$ Once again, the mainstream profession's perceived extremism of these causes would raise questions regarding the movement's relationship with the Communist Party and directly challenge the conduct of the profession.

The movement's commitment to civil rights would directly affect the profession in the midst of the 1935 NCSW conference in Montreal. Three black members of the Home Relief Bureau Employees Association attending the conference were refused accommodations by six hotels and appealed to the rank and file's NCC for assistance. Word of the situation reached Mary van Kleeck as she 
was making a presentation, and she interrupted her remarks to publicly condemn the act, calling upon the conference officers to ensure that in future all NCSW meetings be held in cities that would not discriminate against racial minorities. Conference delegates subsequently adopted a resolution condemning racial discrimination, and a delegation led by rank and file delegates met with the General Secretary of the Conference to ensure accommodations for the black delegates. ${ }^{92}$ Following the meeting, The NCSW Executive Committee issued a statement on the incident:

The Executive Committee wishes to go on record to the Montreal Committee on Arrangements commending them for their success in conforming to the policy of the Conference in obtaining accommodations for delegates of the Conference, and notes with satisfaction the absence of undesirable experiences of discrimination arising because of racial factors in housing and caring for the delegates. The Executive Committee, however, deplores the several instances of discrimination which have arisen locally outside the responsibility or activity of the ...Committee, which indicates attitudes of discrimination against Negro delegates. $^{93}$

Dissatisfied with the statement, representatives of the NCC called upon the conference leadership to take measures to ensure non-discriminatory treatment of delegates at the 1936 conference scheduled for Washington, D.C., a city known for extensive racial covenants in public accommodations. Rank and file delegates were further angered when the publication of the conference proceedings included an unprecedented footnote in the published version of Mary van Kleeck's speech, in which she denounced the incident. Indeed, the addendum to the paper appeared more defensive than explanatory, noting that "...these members had arrived late without advance registration...Moreover, after offering to secure rooms which were 
not accepted because they were too far away and at too high a rate, the Committee...made hotel space available."${ }^{.94}$

In response to the concerns of conference delegates and the NCC, the NCSW Executive Committee agreed to examine their policies regarding non-discrimination before the Washington, D.C. gathering. Dissatisfied with the response of the NCSW, the NCC continued to apply pressure on the NCSW Executive Committee, and eventually the $1936 \mathrm{NCSW}$ was moved to Atlantic City as the committee could not obtain guarantees of non-discrimination in Washington, D.C. However, racist incidents that sparked protest at the 1935 conference were repeated in Atlantic City after one of the hotels that had signed agreements of non-discrimination with the NCSW refused to serve black delegates in their bar and lounge. Once again, the NCC protested the NCSW's lack of response and demanded the NCSW vigorously enforce its own policies. ${ }^{95}$

NCC representatives met with Conference General Secretary Howard Knight, who advised the NCC that it was the position of the NCSW that the guarantee of non-discriminatory accommodations did not include bar service. Upon the demands of the NCC, the issue was brought before the NCSW Executive Committee, which affirmed its belief that "...the Conference has no responsibility beyond essentials and would not give consideration to the use of cocktail bars." ${ }^{.96}$ Carrying their demands to NCSW President Edith Abbott, the NCC called upon her to reverse the policy of the Executive Committee and attempted to smooth the now sour relations between the rank and file and the NCSW: 
The principle at issue is not prohibition or temperance, but equal treatment. Mr. Knight in our discussion feared the development of ugly situations if Negroes and whites drink together...there are members of the Executive Committee who misunderstood our motives in raising this issue, and who believe that our sole purpose is to embarrass the Conference...[The NCC] assure you of our wholehearted desire to work sincerely and constructively with the Conference. $^{97}$

But if the NCC expected Abbott to reverse policies and seek more cordial relations

with the rank and file, they would be disappointed in her reply:

With regard to the question you raise about the Conference making a formal demand for equal treatment of Negroes at the bar, I assume Mr. Knight will have told you about the official action of the Conference. This was that we took no action regarding this particular issue...My reason for thinking that we should take no action is that I believe that the business of the Conference is to make it possible for all of our membership to have an opportunity to attend all of our meetings...I do not think that it is the business of the Conference to assure any kind of recreational facilities to any of its members. If a golf club gives privileges to men and not to women, this seems to me a matter about which the Conference is not concerned. If a bar admits men and excludes women, this seems to me again a matter about which we have no concern. This applies also to the matter of any racial lines that may be drawn in these fields. $^{98}$

While the rank and file had mixed success with the established leaders of the NCSW, they were more successful, and more militant, in the protection of the rights of black relief workers and black relief recipients. This was particularly true in New York City, where the majority of black relief workers were employed and the rank and file unions were the most organized and numerous. Here, the work of the rank and file unions in the Harlem district of New York was most prominent. As early as 1934, relief workers in the Harlem HRB established close connections with the 
Communist Party's League of Struggle for Negro Rights (LSNR), first established in 1930 to oppose lynchings. ${ }^{99}$ By 1934 , the LSNR had joined with unemployment councils in campaigns against job discrimination in the local relief offices. The Harlem branch of the Communist Party had concentrated on relief employees in its organizing efforts and had successfully established several shop units in the Home Relief Employees Association HREA), providing previous leadership in the HREA's protests against racial discrimination in the Civil Works Administration. In April of 1934, the HREA joined with the LSNR in sponsoring a series of public meetings protesting the dismissals of black relief workers and discriminatory treatment of black clients. Following several meetings with relief officials, coupled with demonstrations in and outside of relief offices, the HRB reinstated several black relief workers and agreed to appoint blacks to the HRB's grievance committees. ${ }^{100}$ The HREA would be equally important in the LSNR's attempts to pressure a cafeteria near a Harlem relief office to hire black countermen. As the customer base of the cafeteria was largely composed of HRB employees, a union supported boycott coupled with picketing and demonstrations outside the cafeteria soon led to the cafeteria hiring several black employees. ${ }^{101}$

In October of 1934, the HREA again protested discriminatory practices within the HRB, including charges that the HRB unfairly denied supervisory promotions to black relief workers and demanding the hiring of additional black relief workers. The HREA held a mass protest rally of Harlem relief employees to publicize their demands, only to have the HRB respond with the firing of the 
association's leader. Stung by the HRB's actions, the union mobilized community support, including the LSNR, the International Labor Defense (the Communist Party's legal defense organization), and local black ministers and politicians to form a Joint Committee on Discriminatory Practices to pressure the HRB. Following several months of demonstrations, protest meetings and marches, the HRB reinstated the association's chairman, promoted a number of black workers to supervisory positions and increased their hiring of black relief workers. The campaign was so effective that by the end of 1935 , black relief workers represented the largest number of black professionals employed by the city. ${ }^{102}$

The rank and file relief unions would also strongly protest discriminatory practices within the WPA, CWA and the PWA in New York and throughout the country with mixed success. In New York, the union was instrumental in organizing campaigns within the black community to demand that black workers were provided a proportional number of jobs in WPA projects, with an emphasis on work training in skilled labor. While the WPA refused to adopt a quota system, they did increase their hiring of black workers generally and into skilled work in particular. A similar campaign in Illinois, while not as extensive as the New York efforts, yielded more modest gains. ${ }^{103}$

Civil rights issues were also prominently featured in the pages of Social Work Today, including reports on the struggles in Harlem, the activities of the National Negro Congress, the needs of urban blacks and the treatment of blacks in the programs of the New Deal. ${ }^{102}$ Indeed, where rank and file unions were yet to be 
established, the journal could do little more than expose discriminatory practices. ${ }^{104}$ This was particularly true of Los Angeles in 1934, which Social Work Today described in an article entitled "Jim Crow in Relief":

It is a rigid rule that a Negro case worker must not serve white clients. The rule does not work conversely; white case workers may and do visit Negro applicants...There is not a single Negro district director in the Los Angeles County Relief Administration, and there are only three case work supervisors...LACRA divides its files into 'black files' and 'white files.'

In a number of instances, workers on projects have united to protest against attempts to separate them on the basis of race. Social workers are much more backward. I do not know of a single instance where case workers have done anything to balk segregation or discrimination either in their own work or among the clients of the agencies they serve. ${ }^{105}$

While racial discrimination in relief practice would continue throughout the 1930s, the later development of national federations of social work unions within the CIO would strengthen anti-racist organizing, and propel these unions into the forefront of $\mathrm{CIO}$ unions most committed to anti-discrimination practices and the promotion of black members into union leadership positions. ${ }^{106}$ 


\section{Notes to Chapter 4}

1. "A glossary for rank and filers P-S," SWT, (March 1936), p.23.

2. Gertrude Springer, "Rising to a new challenge," Survey (June 1934), p. 179.

3. Franklin Roosevelt, quoted in Leighninger, Social work: Search for identity, p. 60.

4. Reynolds, An uncharted journey, pp. 159-160.

5. Gertrude Springer and Helen C. Baker, "The national conference at work," Survey (June 1934), p. 187.

6. Moore, Mary van Kleeck, pp. 49-51. van Kleeck's opposition to the NRA was fully articulated in "Prosperity through scarcity: The status of the workers under the NRA," Common Sense (September 1933), pp. 8-10. Regarding her support of the Soviet Union, see Mary van Kleeck, "Dictatorships and democracy," Soviet Russia Today (November 1933), pp. 6-8, 15; Mary van Kleeck, "Observations on management in the Soviet Union," Taylor Society Bulletin (April 1933), pp. 31-36.

In an interview with the author, Barbara Klein (a rank and file member and friend of van Kleeck) recalled that van Kleeck's controversial positions, including her resignation from the Labor Service Council, her membership on the board of the ACLU and, in particular, her support of the Soviet Union was viewed by some in the leadership of the AASW as evidence that the rank and file movement was "in bed" with the Communist Party, and thus "...to be avoided at all costs" (August 2,1980 ).

7. “Social work conferences: 1934 style," SWT (July-August 1934), p. 3.

8. Springer, "Rising to a new challenge," Survey (June 1934), p. 179.

9. Mary van Kleeck, "Our illusions regarding government," Proceedings of the National Conference of Social Work, 1934 (Chicago: University of Chicago Press), p. 484.

10. Ibid., p. 485 .

11. Springer, "Rising to a new challenge," Survey (June 1934), p. 179. 
12. William Hodson, “The President's position," Survey (June 1934), p. 189. It was possibly nettling to Hodson that van Kleeck's paper was awarded the conference's prestigious "Pugsley Award," awarded to papers that were deemed important contributions to the field.

13. Gertrude Springer and Helen Baker, "The national conference at work," Survey (June 1934), pp. 184-185.

14. "Conferences: 1934 style," SWT (July-August 1934), p. 4. van Kleeck quote from: Mary van Kleeck, "The effect of the N.R.A. on labor," Proceedings of the National Conference of Social Work, 1934 (Chicago: University of Chicago Press), p. 434.

15. For example, see: “Whose security?” SWT (January 1935), p. 4; Dorothy Douglas, "Unemployment insurance - For whom?" SWT (February 1935), pp. 912; James Lasswell, "Shovels and guns: The CCC in action," SWT (April 1935), pp. 9-13, 34; and Mary van Kleeck, "Sources of power for the social work program," SWT (December 1935), pp. 8-11.

16. Fisher, "Social work and liberalism," SWT (May-June 1934), p. 12.

17. Eduard C. Lindeman, "The future of the professional," SWT (June-July 1934), p. 15.

18. Personal communication, Chauncey Alexander, August 26, 1980. Alexander, a leader in the National Association of Social Workers during the 1970s and 1980s, recalled that "...most of the leadership of the AASW assumed the rank and file was led by Communists and treated it accordingly."

19. Howe and Coser, The American Communist Party, pp. 178-179; Institute of Marxism-Leninism, Outline history of the Communist International, pp. 295-348; Klehr, The heyday of American communism, pp. 12-17.

20. Howe and Coser, Ibid., Klehr, Ibid.

21. Quoted in Klehr, The heyday of American communism, p. 94. A full explication of the party's views on the New Deal during this period can be found in: Earl Browder, What is the New Deal? (New York: Workers Library, 1933); and Earl Browder, "Recent political developments and some problems of the United Front," The Communist, 14(7) (1935), pp. 604-624.

22. Interview by author with Margaret Levy, September 13, 1980. 
23. "Mr. Roosevelt - so far," The Nation (June 28, 1933), pp. 711-712.

24. "The crisis of the N.R.A.," New Republic (November 8, 1933), p. 350.

25. Interview by author with Margaret Levy, September 12, 1980; interview by author with George Wolfe, July 3, 1980. Wolfe was an editor of Social Work Today and recalls that "....more than one leader of the local and national AASW called me and the journal Communists. To be fair, our 'line' did in fact closely resemble the party's, but we were not the Daily Worker or Political Affairs, we were an independent journal that shared many of their views. I leave the determination of 'domination' to history."

26. While the exact authorship of the bill is unclear, Louis Weinstock, a party member and in 1933 executive secretary of the AFL's Trade Union Committee for Unemployment Insurance and Relief, credits van Kleeck with the original draft (Folsom, Impatient armies of the poor, p. 391).

27. Dorothy Douglas, “Unemployment insurance for whom?" SWT (February 1935), p. 12.

28. Ibid.

29. Maynard Boyer, “A people’s congress," SWT (February 1935), pp. 5-7.

30. Jacob Fisher, "Meet the relief administration," $S W T$ (February 1935), pp. 8-9.

31. Complete proceedings of the first national convention of rank and file groups in social work, Jacob Fisher Papers, SWHA, Box 1, Folder 3.

32. "An open letter from Mary Van Kleeck," SWT (February 1935), p. 12. See also Lorenz Finison, "Radical professions in the Great Depression. An historical note: The InterProfessional Association." Radical History Review, 4(2-3) (1977), pp. 133-136.

33. Finison, "Radical professions in the Great Depression," RHS 4(2-3) (1977), pp. 133-136.

34. Report of the A.A.S.W. Committee to Outline a National Social Welfare Program (December 7, 1934). Harry Lurie Papers, SWHA, Box 1, Folder 3.

35. Memorandum from Mary van Kleeck to Harry Lurie, October 26, 1934. Harry Lurie Papers, SWHA, Box 1, Folder 3. 
36. Ibid.

37. Ibid.

38. Ibid.

39. Ibid.

40. Report of the A.A.S.W. Committee to Outline a National Social Welfare Program (December 7, 1934), Harry Lurie Papers, SWHA, Box 1, Folder 3.

41. Ibid.

42. Letter from Grace Abbot to Harry Lurie, February 5, 1935; block quote of West from Letter from Walter West to Harry Lurie, January 26, 1935; Letter from Helen Crosby to Harry Lurie, January 23, 1935; and letter from Linton Swift to Harry Lurie, January 30, 1935, Harry Lurie Papers, SWHA, Box 1, Folder 3. Kahn quotes as cited in Leighninger, Social work: Search for identity, p. 64.

43. Marcel Kovarsky, “AASW at Washington,” SWT, (April 1935), p. 23.

44. Ibid.

45. Ibid.

46. Ibid.

47. Grace Marcus quoted in Leighninger, Social work: Search for identity, p. 66.

48. David C. Coyle, "Illusions regarding revolution," Survey (July 1934), pp. 213214. Jacob Fisher notes in The response of social work to the Depression that Survey editor Paul Kellogg, unhappy that his journal was required to publish van Kleeck's "Our Illusions Regarding Government" due its receiving the Pugsley Award, was concerned that "...this frank espousal in the pages of the Survey of what sounded like socialism and might even be taken by some as communism" (p. 76).

49. Dorothy Kahn, "Professional standards in social work," Compass (June 1935), p. 1.

50. Porter Lee quoted in Ehrenreich, The altruistic imagination, p. 116. Originally published in Porter Lee, "A critical period in education for social work," Bulletin 
of the New York School of Social Work (October 1934).

51. Jacob Fisher, "Rank and file challenge," SWT (April 1935), p. 5.

52. "NCC at Montreal," SWT (July 1935), pp. 7-8; "Rank and File Bulletin," Jacob Fisher Papers, SWHA, Box 1, Folder 7.

53. "NCC at Montreal," SWT (July 1935), p. 8.

54. Ibid., pp. 7-8.

55. Mary van Kleeck, "Social work in the economic crisis," Proceedings of the National Conference of Social Work, 1935 (Chicago: University of Chicago Press), p. 75.

56. Eduard Lindeman, "The future of the professional," $S W T$ (July-August 1934), p. 15.

57. Mary van Kleeck, "Sources of power for the social work program," $S W T$ (December 1935), p. 11.

58. Ibid.

59. Harry Lurie, "The dilemma of the case worker," $S W T$ (October 1935), pp. 13-15.

60. Ibid., p. 15.

61. Ibid.

62. Bertha Reynolds, "Whom do social workers serve?" SWT (May 1935), pp. 5-7, 34.

63. Ibid., p. 6 .

64. Ibid.

65. Ibid.

66. "AASW examines the Dawson case," $S W T$ (February 1935), pp. 25-27; quote as cited in "The case of Sidonia Dawson, Survey (January 1935), pp. 8-9.

67. Jacob Fisher Papers, SWHA, Box 1, Folder 7. 
68. Ibid.

69. Ibid.

70. George Hedin, "Spying, discrimination, dismissals," SWT (May 1935), pp. 13-14

71. “AASW examines the Dawson case," SWT (February 1935), p. 26.

72. Ibid.

73. Ibid.

74. "The case of Sidonia Dawson, Survey (January 1935), p. 9.

75. George Hedin, “The Riback firing,” SWT (February 1935), pp. 16-17

76. Quotes from Ibid.; "Rank and file," SWT (February 1935), p. 1.

77. A.V. Barnard, “Insubordination in New Jersey,” SWT (April 1935), pp. 27-28.

78. Ibid.

79. Ibid.

80. DeWitt Gilpin, "Fired for inefficiency," $S W T$ (November 1935), pp. 11-14; Manfred Willmer, "Victory in Baltimore," SWT (November 1935), pp. 22-23; "Red Squad on coast," SWT (April 1935), p. 26.

81. $S W T$ (April 1935), p. 4.

82. George Hedin, "Spying, discrimination, dismissals," SWT (May 1935), pp. 1314.

83. Home Relief Bureau Employes Association, Spies, dismissals, discrimination: The report of the Investigating Committee of the Association of Workers in Social Agencies (April 1935), Jacob Fisher Papers, SWHA, Box 1, Folder 9.

84. Daniel Allen, "Our jobs need us!," SWT (December 1935), pp. 5-7; Fisher, The response of social work to the Depression, pp. 108-109; "Worker and client join hands," SWT (January 1936), p. 18.

85. “Social work practices,” SWT (May-June 1934), pp. 16-17. 
86. "Should social work employes use labor tactics?," SWT (February 1936), p. 18.

87. Ibid.

88. Letter from John A. Fitch to Harry Lurie, October 30, 1934. Harry Lurie Papers, SWHA, Box 1, Folder 5.

89. "Should social work employes use labor tactics?," SWT (January, 1936), p. 5.

90. Minutes of the New York Chapter, AASW, 1934-1935. Harry Lurie Papers, SWHA, Box 1, Folder 5; personal communications with author from: Chauncey Alexander (August 26, 1980); Eleanor Cohen (February 12, 1994); Marie Talbot (December 4, 1979; Max Bogner (August 12, 1980); and Margaret Wheeler (September 19, 1979).

91. For example, see: Martin Reimer, "The unemployed - Second class citizens," SWT (May 1935), pp. 16-18; L. Miller, "Jim Crow in relief," SWT (May 1935), p. 28; "The open forums," SWT (January 1935), pp. 27-28; Roger Baldwin, "Social workers and war," SWT (February 1935), p. 28; A. Brandt, "Why men fight," SWT (February 1935), pp. 28-29; and Child Care Commission, "Children of the new Spain," SWT (November 1937), pp. 9-10.

92. Fisher, The response of social work to the Depression, pp. 134-135; 165-167.

93. Proceedings of the National Conference of Social Work, 1935 (Chicago: University of Chicago Press), p. 76.

94. Ibid.

95. National Coordinating Committee of Social Service Employee Groups, Statement on an instance of discrimination against Negro members of the National Conference of Social Work (May 30, 1936), Jacob Fisher Papers, SWHA, Box 1, Folder 6.

96. Letter from Howard Knight to Jacob Fisher (October 26, 1936), Jacob Fisher Papers, SWHA, Box 1, Folder 6.

97. Letter from Jacob Fisher to Edith Abbott (November 30, 1936), Jacob Fisher Papers, $S W H A$, Box 1, Folder 6.

98. Letter from Edith Abbott to Jacob Fisher (December 11, 1936), Jacob Fisher Papers, SWHA, Box 1, Folder 6. 
99. Naison, Communists in Harlem during the Depression, pp. 107-108

100. Ibid.; Allan McKenzie and Harry Doliner, The Negro worker and the ERB (New York: Association of Workers in Public Relief Agencies, 1937) [Pamphlet], pp. 1-2.

101. Naison, Communists in Harlem during the Depression, pp. 120-121.

102. McKenzie and Doliner, The Negro worker and the ERB, pp. 1-23; Naison, Communists in Harlem during the Depression, pp. 122-124.

103. McKenzie and Doliner, The Negro worker and the ERB, pp. 1-10; Second session of the National Coordinating Committee's second rank and file conference, Jacob Fisher Papers, Box 1, Folder 5; interview by author with Abram Flaxer, August 16, 1980.

104. For example see: Loren Miller, "Jim Crow in relief," SWT (May 1935), p. 28; Peter Milo, "Doin' something FOR Negroes," SWT (January 1937), pp. 13-14; James Hubert, "Needs of Negro children," SWT (April 1937), pp. 13-14; Lester Granger, "Harlem comes of age," SWT (May 1937), pp. 9-12; James H. Baker, "A great second conference," SWT (December 1937), pp. 9-10; Lester B. Granger, "The urban colored population," $S W T$ (March 1938), pp. 10-12; and R. Logan, "The Negro and the New Deal," SWT (September 1939), pp. 7-8.

105. Miller, "Jim Crow in Relief," SWT (May 1935), p. 28.

106. McCulloch, White collar workers in transition; Rosswurm, The CIO's left-led unions; interview by author with Abram Flaxer, August 16, 1980. 


\section{CHAPTER 5:}

\section{TOWARDS A UNITED FRONT: THE RANK AND FILE IN ITS MIDDLE YEARS}

As never before, American social work today must integrate itself in the wide, social community. It must find its friends and it must isolate its enemies...Social work is passing from social isolation to genuine social diagnosis; now it must pass along to matured social action...By and large the New Deal years are coterminous with the period in which social work has become organic in government. In these months social work is called upon to prove whether it is capable of sustaining and enhancing the relationship.

(Social Work Today, 1938)

As delegates to the Second National Convention of Rank and File Groups in Social Work gathered in Cleveland in 1936, the rapid expansion of social work unions nationwide now posed new questions in regard to their relationship to the broader labor movement. At the 1935 founding convention, unions and discussion clubs affiliated with the NCC had pointedly rejected affiliation with the AFL. Concerned with the craft nature of AFL organizing, delegates to the 1935 conference had avoided reference to AFL affiliation in their published reports and resolutions. Rather, in their debates, delegates expressed the fear that affiliation with the AFL would result in the formation of weak and isolated unions separated by the AFL's preference to develop multiple craft unions representing different classes of employees within single agencies. ${ }^{2}$

But following the 1935 conference, an increasing number of the NCC's affiliate unions began joining the AFL, seeking to institutionalize both their 
recognition by employers and their bargaining efforts with agencies within the less isolated context of a national federation of unions. ${ }^{3} \mathrm{AFL}$ affiliation also reflected the relatively weak position of the NCC - it could provide neither the financial or organizational resources needed by unions in their organizing struggles that were available to them through the AFL. Indeed, the NCC's financial report presented at the 1936 conference indicated a total income of only $\$ 488.00$ during the year and a deficit of nearly $\$ 200.00 .^{4}$ Alarmed that individual union affiliations with the AFL, in the absence of a strong national social service employee union, would weaken rank and file efforts, the NCC opposed AFL affiliation despite its own rapidly devolving role into one of a mere clearinghouse of information for unions. Holding to its hopes for a national union, the NCC passed official resolutions asking unions to use restraint when considering such affiliation and argued its case in Social Work Today:

The problem presented by the relation of a national organization to the A. F. of L. is not merely one of affiliation or non-affiliation. In view of the craft character of the great majority of A. F. of L. unions the question of the circumstances under which affiliation could be obtained is of paramount importance...In the judgement of the $[\mathrm{NCC}]$, the advantages of retaining the vertical union form of organization outweigh the values accruing from individual A. F. of L. affiliation on a craft basis...the development of a sufficiently large and powerful vertical union in the field of social work would make it difficult for the A. F. of L. to refuse an application for a charter backed by the will of twenty or thirty thousand union members...[Affiliation] is conditioned entirely by the effective launching of a national organization. ${ }^{5}$

Despite the calls of the NCC to avoid AFL affiliation in lieu of one national union of social service workers, a number of public relief worker unions, most 
notably workers in the Baltimore Transient Bureau, requested and were granted charters as lodges of the AFL's American Federation of Government Employees (AFGE). By the time of the 1936 conference, the NCC's largest affiliate, New York's Association of Workers in Public Relief Agencies, was also seriously considering AFL affiliation, as were the Philadelphia Association of County Relief Board Employees and the Chicago Association of Workers in Public Agencies. Further weakening the arguments of the NCC, in December 1935 the AFGE announced the formation of the American Federation of State, County and Municipal Employees (AFSCME). Unlike its parent, the AFGE, AFSCME adopted a vertical or industrial form of organization, opening its membership to clerical and technical workers as well as professionals. With some $10,000 \mathrm{AFL}$ members immediately eligible for transfer into AFSCME, it appeared that the affiliation of NCC unions with AFSCME would thus fulfill the demands of the NCC for a large national union. $^{6}$

Reflecting the inexorable move of rank and file unions into the AFL, delegates at the Cleveland NCC convention affirmed affiliation with the AFL. While delegates expressed continued support of the NCC for its efforts as a source of information and coordination for organizing efforts, they uniformly endorsed AFL affiliation. In a report of the relationship between the AFL and social work unions, delegates enthusiastically supported affiliation, ending the report with a fictional dialogue between two social workers on the merits of joining the AFL: 
Bill: Say, Sam what's this about your favoring our association affiliating with the A. F. of L.?

Sam: I think if everyone knew the advantages we'd gain from affiliation, we wouldn't be able to get in soon enough.

Bill: What are some of the advantages that you think we'll get?

Sam: Well, in the first place we'll be directly federated to over $3,000,000$ wage and salary earners throughout the country now organized in the A. F. of L....This can help us in swinging the support of the labor movement in this city to maintaining and advancing public provisions for social services and unemployment relief...Speaking in the interests of a large proportion of the city's population on relief and also on behalf of the organized workers in the community, our delegations could have considerable weight...

Bill: How can we answer the arguments raised that joining the A. F. of $L$. will interfere with the desirable professional objectivity of social workers?

Sam: There are two sides to this question of objectivity. As professional social workers we have an obligation to maintain and advance the standards of social welfare. We should support those groups who are also working in this direction. We should recognize that labor in its organized struggles to improve wage and working standards is paralleling the efforts of social workers to raise standards...

Bill: Well, Sam, you can count on me to help in talking it up. I believe you're right that we'll find new enthusiasm and new energy by A. F. of L. affiliation. With the support of organized workers of all types...we should be able to advance our movement as well as being of some real assistance to the A. F. of L.

Sam: Put it there, Bill! Gee, it's 6:30 and my dinner is calling. What do you say we close shop? ${ }^{7}$

Presaging the coming dissolution of the NCC, the conference's Constitutional

Committee reversed its plan to increase the NCC's budget, instead retaining its 1935 financial allotment. Formalizing the NCC's redefined role as one of information and coordination versus acting as a proto-union, and sensitive to charges that the NCC might be viewed as engaging in dual unionism in opposition to the AFL, the 
convention revised its constitution to describe the NCC as a "committee," deleting its previous description of the NCC as an "organization."

Following the 1936 NCC convention, rank and file affiliation with the AFL's AFSMCE accelerated. Within months, major rank and file unions made the move, including the New York and Chicago unions, the Washington, D.C. Federation of Social Workers, the Milwaukee County Department of Relief Workers Union, the Minneapolis Social Workers Council, and the Association of Philadelphia County Relief Board Employees. As the mergers continued, AFSMCE membership swelled to over 25,000 , representing some fifteen lodges of state, county and municipal employees. By the end of 1937 there were some 21 lodges representing workers nationwide in family social service agencies, recreation and community centers, employment bureaus, relief agencies and settlement houses. ${ }^{9}$ Despite its initial reservations regarding AFL affiliation, shortly after the NCC conference, Social Work Today acknowledged that "...the vigorous campaign for A. F. of L. affiliation... has borne fruit." 10

As public relief unions moved into the AFL, so did significant numbers of unions representing social workers in private charity agencies. Most prominent of these unions was the New York Association of Federation Workers, which was granted a charter in 1936 with the AFL as the renamed Social Service Employees Union (SSEU). With an initial membership of 400 members, the New York SSEU lodge was soon joined by SSEU unions in Chicago, Philadelphia and Los Angeles, 
and within the next year the SSEU would claim five chartered locals and several thousand members. ${ }^{11}$

With the rapid affiliation of the NCC's constituent unions into the AFL, the continuing usefulness of the NCC came under question. While the NCC had not fulfilled its goal of one national union representing both public and private workers, the establishment of AFSCME and the SSEU appeared to be the most realistic approximation of their hopes. Accordingly, the NCC issued a report to its members in January 1937 recommending dissolution. Citing evidence that the emergence of the two national AFL unions had essentially completed the goals of the NCC, the report requested a vote on dissolution at its next membership meeting. Dissolution was formally voted on at the annual conference, and the NCC's control of Social Work Today was terminated, now leaving it as an independent journal.

Responsibility for planning programs at annual NCSW meetings was placed in a joint committee representing rank and file unions. ${ }^{12}$

\section{The Second New Deal and the Popular Front}

As rank and file unions gravitated towards the AFL, they faced new practical and political challenges in the face of President Roosevelt's reelection in 1936 and the institution of his second phase of the New Deal. During Roosevelt's first term rank and file unions and their leaders had been highly critical of New Deal programs, criticism that had intensified with the termination of FERA and retraction in WPA programs. Reflecting the disenchantment of the rank and file with the New Deal, Social Work Today published numerous articles in 1935 and 1936 outlining the 
movement's opposition. Headlining its May 1936 issue with the banner "Quitting

the Relief Business," the journal featured articles condemning the Roosevelt

administration's failures in serving the unemployed, youth and resident aliens. ${ }^{13}$ In

its lead article, Harry Lurie summarized the movement's major complaints:

With the wreckage of the NRA and of other attempts of the New Deal to find a more modern method of coping with the economic depression and salvaging the economic order, it became essential for the federal government to revise its relief program and its relief theories. Piece by piece, the social welfare program, much of it still on paper or in speeches, was dismantled or forgotten. First, Section $7 \mathrm{a}$ of the National Industrial Recovery Act which encouraged labor union organization was repealed through a process of administrative erosion. Wage rates in the codes were dropped to a discouraging degree. The "social security" plans became the Wagner-Lewis bill, acknowledged even by some of its friends as having unsound provisions and inadequate benefits. A broad housing program for the low income classes expired without even a blue print to mark its burial, and industrial and land settlement programs were whittled away long before the fanciful and unsubstantial character of the projects could be demonstrated...The termination of FERA in 1935 and the restriction of the federal program to WPA, completed the demolition of the original unemployment relief structure. ${ }^{14}$

As the rank and file approached the 1936 election, many in the movement supported the Communist Party's efforts to promote a Farmer-Labor Party, including delegates to the NCC's 1936 convention. In its 1936 national platform the NCC, while deciding not to formally endorse support of the Farmer-Labor Party, put forth a strong appeal for social workers to reject both the Democratic and Republican parties:

...the growing movement for a new political party, representing the workers, farmers and professionals, speaking in their own interests and designated as a Farmer-Labor Party, demands a critical 
examination by social work organizations to determine how closely our programs are identified and the power such a political grouping would represent for the fulfillment of this program. Following such an examination, we have an obligation to support that political party whose aims accord with ours and which has the power to achieve these aims. ${ }^{15}$

Despite the calls in early 1936 by the NCC and Social Work Today for the formation of a Farmer-Labor Party to challenge Roosevelt, the position of the movement began to rapidly shift towards Roosevelt as the election approached. In October 1936, the editors of Social Work Today now provided an assessment to its readers that the defeat of Republican Alf Landon was of paramount importance, declaring "Slogan number one: Fight Landon!" 16 While not directly endorsing Roosevelt, the journal's choice was clear. Declaring that a victorious Farmer-Labor Party would not be possible until 1940, the editors urged readers to support Farmer-Labor local, state and congressional candidates, pointedly omitting support of its Presidential candidate. To complete the sudden alignment of the movement to a critical but supportive stance regarding Roosevelt, Social Work Today responded to his subsequent overwhelming reelection victory with a seemingly placid and surprising response considering its previous hostility:

In the election of 1932, the majority of American voters registered their dissatisfaction with the Republican Party, the governmental policies and the administration of Herbert Hoover. Now, four years later, an even larger majority register a more vigorous rejection of the Republican candidates, sponsors and platform...There is no question but that the election gave unmistakable evidence of the desire of the majority of the American people for liberal and progressive policies of government, for social security provisions and for increased governmental control over business organization. ${ }^{17}$ 
Indeed, over the next few months, the political line of Social Work Today dramatically swung from one of bitter opposition to Roosevelt to more critical acceptance. In February 1936, the journal featured an article by soon-to-be editor Frank Bancroft on the priorities facing the new Congress. Bancroft, declaring "We elected Franklin Roosevelt and the United States Congress to tackle the problem of unemployment head-on," outlined a program of legislative reform not far from the President's own positions, including passage of a National Labor Relations Act, liberalization of the Social Security Act, and increased benefits for the unemployed. ${ }^{18}$ Two months later, in an editorial entitled "We Support the President," the editors of Social Work Today announced their full support of Roosevelt's proposal to expand the Supreme Court, declaring that "...the crushing defeat administered reaction in the November elections makes of the President's plan the primary issue facing the country...The place of all social workers is with the President on this issue." 19

More tempered support of Roosevelt would continue throughout 1937, 1938, and 1939. By 1938, the pages of Social Work Today no longer called for the dismantling of the capitalist system and its replacement with a worker's democracy modeled after the Soviet system. Instead, the journal acknowledged defense of the New Deal as a primary task facing the rank and file, declaring that the central issue was "...the people and Roosevelt versus special privilege and popular betrayal."20 Urging social workers to rally behind the programs of the New Deal, Social Work 
Today, while somewhat grudging in its support, linked the New Deal's success with that of social work's own advancement:

Imperfectly, unevenly, inadequately, the New Deal administrative and legislative block have, since the 1936 national elections, tried to carry forward a program of recovery and reform. By every demagogy known to the long and dishonorable history of that black art, anti-social forces have tried - and all too often succeeded - to hamstring that program... Wherever...concrete unity is achievable, it is of the most critical importance to the program of social work...To the extent that we are realistic, we will that that a unified labor movement is our greatest single ally. ${ }^{21}$

Despite the movement's growing affection towards the New Deal, its support remained at least initially guarded, and Social Work Today continued to voice the movement's condemnation of failures in the administration's social and economic programs, most notably the tepid performance of the WPA, the lack of quality and sufficient numbers of low income housing, services for migrant workers, the needs of youth, and Roosevelt's alleged foot dragging on civil rights and anti-lynching legislation. ${ }^{22}$ However, by the end of 1939 the movement had put aside most of its criticisms and now fully embraced the New Deal, declaring "The New Deal is Our Deal":

Times have changed...The New Deal is the determination of the American people to make democracy the organizing principle of all of their national life...The pre-depression days are gone. Before us lies a new era, a new ordering of the affairs of men. SOCIAL WORK TODAY believes that social workers want it to be more democratic, not less. It believes that the continuation, consolidation and extension of the New Deal is the only immediate way to insure this result. ${ }^{23}$ 
The journal's now solid support of the New Deal was echoed within the unions whose opinions it represented. Joining with Social Work Today, Abram Flaxer, a former leader within AFSCME and now President of the CIO's State, County and Municipal Workers of America (the largest national union of relief workers), pronounced labor's new faith in the New Deal:

The New Deal has made government service a more adequate service to the people, by concerning itself with social services...A people's government must be staffed by men and women of the people. The people who man the job must not only be fit to perform the job but also should be of a mind to defend the New Deal. The strongest defender of the New Deal is labor. ${ }^{24}$ (emphasis added)

The initial and sudden shift of the rank and file movement in 1936 from open hostility to the Roosevelt administration to its gradual rapprochement and eventual embrace of the New Deal by 1939 reflected more than a sudden maturation or abandonment of the politically-left analysis of its leaders such as Mary van Kleeck or Bertha Reynolds. Rather, it mirrored a strategic shift in strategy heralded with the Communist Party's halting adoption in the period between 1935 and 1936 of its Popular Front approach to political work, reflecting the close relationship enjoyed between the $\mathrm{CP}$ and key leaders of the rank and file movement. Developed in meetings of the Comintern's Seventh World Conference in 1935, the Popular Front line reflected the Comintern's recognition that its campaign against social fascism was in error. While calling the shift a response to "new conditions" as opposed to errors inherent in its Third Period analysis, the Popular Front recognized the increasingly defensive position Communist party's were experiencing worldwide. ${ }^{25}$ 
As reactionary and fascist parties and governments in Germany and other European countries increased in number and power, the Comintern reevaluated its previous rejection of alliances with the forces of bourgeois and social democracy, now calling for a "united front" with its previous enemies on the left. ${ }^{26}$

The American Communist Party's incorporation of the Popular Front strategy was initially slow and marked by confusion. Unsure of the full intent of the Comintern's new position, throughout late 1935 the party's leaders continued their attacks upon Roosevelt and what the party's paper, The Daily Worker, considered the administration's "trend to fascism., ${ }^{, 27}$ Hoping that the formation of a Farmer-Labor Party would provide the basis for a united front, the Communist Party requested and received permission from the Comintern to launch the party in opposition to Roosevelt. However, attempts by the party to garner support from the Socialists, labor leaders and populist political leaders such as Minnesota Governor Floyd Olson and New York's Fiorello LaGuardia failed miserably, as the now new allies of the Communists feared a third party would usher in a Republican victory. Following consultation in Moscow with representatives of the Politburo in May 1936, Communist Party leader Earl Browder returned to the United States, announcing that full formation of the Farmer-Labor Party would be put on hold. Instead, Browder now proclaimed that defeat of the Republican Party and its reactionary allies in the 1936 election was the primary mission of the party, adopting the slogan "Defeat Landon at all costs!"28 And so, in a period of a few months the party's new political line reversed from a course of unrelenting hostility to a new defense of the New 
Deal, a less critical stance regarding Roosevelt, and an emphasis on defending democratic rights within the confines of American capitalism. ${ }^{29}$

The Popular Front strategy would dominate the political activities of the party throughout most of the remaining decade. Now the ranks of labor, liberal organizations, and even the Democratic Party became the focus of party activities. Embarking on what was now called "The Democratic Front," American Communists sought to establish a broad coalition of liberal and progressive organizations in their struggle against domestic and worldwide fascism. Indeed, calls for socialism were no longer deemed necessary or even desirable; rather, working class unity in defense of democracy became the new program of the party as it declared in its 1936 National Convention, "Communism is twentieth-century Americanism." ${ }^{30}$ During the following decade, the new cooperative approach of the Communists would both legitimize their presence in progressive political discourse and extend their influence and prestige into the ranks of organized labor, among intellectuals, and within progressive movements for peace and civil rights. ${ }^{31}$

The extent to which the Communist Party's introduction of the Popular Front strategy directly influenced the rank and file movement's sudden turn in political line in 1936 is, in the final analysis, unknown. However, the close alignment of the movement through the pages of Social Work Today with the party's pronouncements regarding the abandonment of the Farmer-Labor Party and the subsequent embrace of the New Deal was not a matter of sheer coincidence. Influential leaders of the rank and file such as Social Work Today editors Jacob Fisher and George Wolfe 
were party members, as were a significant number of rank and file union leaders, including Abram Flaxer within AFSCME (later head of the CIO's SCMWA, the State, County and Municipal Workers of America ), SCMWA national organizer Henry Wenning, and Lewis Merrill, head of the CIO's United Office and Professional Workers of America and containing a large contingent of social work unions. Similarly, Bertha Reynolds was a member of the party and Mary van Kleeck, while not a member, was closely allied with the party and its top leadership. ${ }^{32}$ While the movement's close mirroring of the party's line would later lead to both charges and denials of communist control, based on the fragmentary evidence perhaps Jacob Fisher most accurately characterizes the relationship enjoyed between the party and the rank and file movement:

The rank and file were often close to the party. Many of us were members or closely associated with its organizations. We read the Daily Worker and were keenly interested in what they had to say. The editorial positions of Social Work Today certainly could be said to sometimes "mirror" the party's lines, but to say we were "dominated" by the party would be simply incorrect. We were as a whole an independent movement and journal, often in agreement with the party and sometimes opposing its positions...The party was certainly powerful in the various public relief unions, and in fact consolidated their control in the CIO through their assuming leadership in key national positions, but for the most part the rank and file members were interested in bread and butter issues and professional standards, not the pronouncements of the party over this thing or that. ${ }^{33}$

\section{Fence Mending With the Profession}

As the movement began to take a more conciliatory approach in its relationship to the policies of the Roosevelt administration, so did it begin to move 
away from its antagonistic relationship with the AASW. In June 1936, Social Work Today published an unprecedented editorial entitled "A Plea for Understanding," extending an olive branch to the profession. Noting the AASW's initiation of a campaign to improve the image of social work in the public eye, the editors asked, "Before we expect understanding from a resistive public, must we not first recognize that there is need for understanding within the ranks of the profession itself?"34 Declaring that the union movement shared a genuine concern with the AASW over professional standards, the editors proclaimed the rank and file in alliance with the AASW, while retaining a divergence in analysis:

The professional society offers a program of interpretation attributing to ignorance and cultural prejudices the major blocks to public acceptance of social work. The trade union cannot accept the concept of an undifferentiated public on whom all the deficiencies of our order are projected. It locates the difficulty in the unwillingness of the wealthy taxpayer to support a welfare program which is both expensive (to him) and which is a threat to the low standard of living in the general population on which his profits depend. $^{35}$

While outlining the differences between the two camps, Social Work Today argued that such differences were one of emphasis and did not constitute a basis for noncooperation. Rather, the editors argued that there was "ample room" for the development of "legitimately separate interests" in such cooperation, concluding "Never have standards affecting clients and staff been so threatened. The dreaded effects of the withdrawal of public relief are upon us. Can social work afford to have its ranks divided? ${ }^{36}$ 
Reminiscent of the movement's shift regarding the New Deal in the wake of the Popular Front strategy, Social Work Today continued to draw closer to the initiatives of the mainstream profession and the AASW. Throughout 1937 the journal increased its reporting on AASW programs, congratulating the association chapters' increasing involvement in the political arena through lobbying and now open support of increased federal assistance:

It is encouraging to consider that the professional organization in our field, the American Association of Social Workers, has loaned itself least to reactionary purposes and has attempted the most progressive action of all similar professional bodies. The causes of this are not far to seek; they grow directly out of the functions of the Association as they are affected by the changing situation in the world about us...The necessity for engaging in some sort of 'social action' is no longer a problem of the Association, for it is seen emerging directly from its purpose. ${ }^{37}$

Now echoing the AASW's concern with the protection of professional standards, rank and file unions took up the cause, most notably in New York City. There union members demanded that the Public Welfare Department stiffen its requirements for hiring of staff into the positions of supervisor by adding "high academic and experience qualifications" combined with a written exam to the position requirements. ${ }^{38}$ Faced with the support of over 50 local unions and the local AASW chapter, the department's commissioner agreed to the proposal and a new civil service examination procedure was implemented. Further acknowledging the AASW's concern that uncredentialed relief workers were threatening the standards of the profession, Social Work Today launched a new series entitled "The Case Work Notebook" in its October 1936 issue. Citing a growing "insecurity" among relief 
workers regarding their ignorance of "professional material," the journal's editors sought to tread a blurry line between the journal's professed dedication to wider social problems and the need of relief workers for more "technical tools":

Case work as a system is slow, individualistic, and still heavy with its infancy. That it can be effective under certain conditions in relation to a limited number is true. But it is not intended as a "mass method." Another aspect that we must not overlook is that the personality troubles toward which case work is directed are heavily precipitated today by the external state of our society...we find ourselves facing the ivory tower of limited techniques or, conscious of our professional responsibility, performing to the limit of our ability the case work function... we believe that further development of the questions raised will help workers in clarifying case work confusion. These and other pertinent questions will be covered in the successive columns of Case Work Notebook. ${ }^{39}$

Over the next four years the Case Work Notebook would address a wide range of case work practice, theory, and technique that was increasingly well within the confines of established approaches taught in professional schools of social work. The monthly column featured discussions on such professionally-oriented topics as the importance of personality in the process of diagnosis and treatment planning, applications of Rankian psychology, the use of relationship in social case work, the role and use of anxiety in treatment, and the importance of balancing identification with client experiences and the objectivity of a professional approach. ${ }^{40}$

The rank and file movement's increased concern with the protection of professional standards through the negotiations of its unions and in the pages of Social Work Today would also be accompanied by growing cooperation with the AASW and leaders of the mainstream profession. Attacks on professional standards 
of training and education, prominent in the early years of the rank and file's

development, were now replaced with a call for alliance with agency administrators

to secure professional standards:

The average practitioner wants to grow professionally. Growth, however, is seldom possible without the full cooperation of agency executives...formal study is necessary to acquire what is tantamount to a anew body of knowledge. Workers can and do take courses offered by experts in the field...As the body of case work knowledge expands, room develops for specialization - as in medicine and other broad professional fields. Some workers become particularly skilled in one area, some in another. In this sense their development is uneven but this does not imply that one type of skill is more valuable over another. Each workers makes his own contribution...The executives and the workers become integral parts of one agency and work together toward ever higher standards. ${ }^{41}$

Increasingly, established leaders of the profession became contributors to Social Work Today as the rank and file modified their criticisms of both the administration and the profession. Once threatened by the massive infusion of untrained relief workers into the field, social work leaders such Karl de Schweinitz and the University of Pittsburgh's Marion Hathway now called for the profession to support the training needs of these workers. Noting that "...trade unionism in the social work of the future will tend more rather than less to be the common meeting ground of trained and untrained personnel," Hathway called for schools of social work to adjust their curriculum and methods of training delivery, institute early morning and late afternoon classes to accommodate workers, and to work with public agencies to provide leaves of absence for workers to attend school. ${ }^{42}$ 
As Social Work Today increased its coverage of more mainstream social work concerns, other members of the mainstream profession became contributors. Building on articles introducing rank and file members to social group work, Grace Coyle advised readers on the relationship between group work and social action, emphasizing that social workers could create a better society through "...orderly and democratic methods of change. ${ }^{, 43}$ Wayne McMillen, who became president of the AASW in 1940, also became a contributor to the journal, expressing sympathetic recognition of the reasoned role of unions in bettering working conditions for members of the profession:

If organization is the best formula for working toward better conditions, then the next question is "What type of organization - a professional organization or a union?" I have been a member of a professional organization for many years and I believe such organizations have a very important contribution to make. But a professional organization would obviously include only a part of the workers in any office....it seems to me an interesting bit of evidence that while you may need a vertical union for protective purposes, you also need a professional organization for other purposes. $^{44}$

Even former enemies of the movement such as Dorothy Kahn and Grace Marcus were no longer an anathema to the rank and file as it moderated its assessments of the profession. Once a target of rank and file criticism for her early resistance to unionization and her criticism of its tactics, by 1940 Dorothy Kahn, now Assistant Secretary of AASW, would praise rank and file unions in the pages of Social Work Today for their opposition to cuts in relief. ${ }^{45}$ Grace Marcus, who earlier believed the rank and file movement was a dangerous trend within the profession spouting 
"...economic dogmas that caricature Marxian theory," was now featured in articles lauding the influence of Sigmund Freud and explaining changes in theories of reliefgiving during the previous decade. ${ }^{46}$ Even Virginia Robinson, who had previously attacked Social Work Today and the union movement for their political extremism and espousal of militant union tactics, now noted in 1937 that "...social workers and rank-and-filers are nearer today in social philosophy than they were five years ago., ${ }^{, 47}$

As the politics of the Popular Front employed by the rank and file movement served to bring them in closer alliance with the mainstream profession, so did the profession's increasing amenability to social action in defense of the New Deal soften their concerns with the movement. The rank and file unions' increasing attention to professional standards, as well as their focus on betterment of workplace conditions were no longer manifestly antagonistic to the goals of the AASW. But tensions between the two camps did not disappear entirely, as the mainstream of the profession continued to be suspicious of the rank and file's more leftist positions on foreign policy and their apparently close relationship with the Communist Party. And as the United States inched closer to war in the late 1930s, the profession's lingering suspicions would turn to both attack on and disavowal of the movement.

\section{Into the CIO}

As relations between the mainstream profession and the movement waxed and waned throughout the latter half of the 1930s, the rank and file's dedication to building a union movement took on renewed vigor. While the dissolution of the 
NCC had marked an end to the dreams of its founders for a single national union of social service employees modeled on the more pure lines of industrial unionism, other dissenting voices within the AFL would emerge to sweep the rank and file movement's unions into a new and militant organization: the Congress of Industrial Organizations (CIO).

Just as rank and file delegates to the 1935 and 1936 NCC conventions debated the advisability of affiliating with the craft oriented AFL, a similar and more momentous struggle was taking place within the AFL itself. The tensions within the AFL over the desires to retain its craft union orientation and simultaneous calls for it to embrace industrial workers into its fold intensified in the early 1930s, finally exploding with the passage of the National Industrial Recovery Act (NIRA) of 1933 and its provisions guaranteeing the right of workers to form unions free of employer influence or control. Despite fierce resistance by employers, a staggering number of workers, primarily located in basic industry, took up the call for union organizing. In an unprecedented display of militancy, workers throughout the country warred with employers to achieve union recognition. In the first year of the NIRA, over 900,000 workers nationwide went on strike and the number nearly doubled in 1934. Trade union membership soared, as nearly three quarters of a million new union members entered the AFL, independent unions, and the Communist's TUUL. For the AFL, which gained nearly 500,000 members in the wake of the NIRA, this new influx of unions represented not only a significant revival of its previously shrinking membership but new dangers to its leadership and its control over the form of these 
new unions. The growing strength of industrial worker unions within the AFL, particularly John Lewis' United Mine Workers (UMW), as well as the International Ladies Garment Workers Union (ILGWU) and the Amalgamated Clothing Workers of America (ACWA) would lead to internal demands that the AFL abandon its craft orientation in favor of industrial unionism. ${ }^{48}$

Dissatisfied with the AFL leadership's resistance to industrial unions, the UMW, ILGWU, ACWA and other industrial unions within the AFL formed the Committee on Industrial Organization in 1935 to challenge their national leadership and promote industrial unionism within the AFL. As the AFL leadership denounced the CIO's formation as dual unionism, it contemplated expelling the CIO unions. Fearful that such expulsions would split the labor movement, the AFL leadership vacillated between expulsion and accommodation of the CIO. But events within the CIO itself would propel the AFL to act decisively. While the AFL debated the merits of expulsion, the CIO continued to develop an internal federation of industrial unions. Responding to the failure of the AFL's Amalgamated Association of Iron, Steel, and Tin Workers to mount an organizational drive among steel workers, the CIO organized its own Steel Workers Organizing Committee (SWOC) in 1936, directly challenging the AFL leadership over control of the industrial union movement. Similar organizing efforts in the rubber, auto, electrical and radio industries would swell the ranks of the CIO in what was now a direct and open challenge to leadership of the AFL. As attempts to maintain unity collapsed in 1937, the AFL expelled the CIO unions. Under the leadership of the UMW's John Lewis, 
the expelled unions formed the Congress of Industrial Organizations in November of 1938, challenging the AFL for control of the entire national labor movement. ${ }^{49}$

The formation of the CIO would have a catalyzing effect upon the rank and file's AFL unions. In the summer of 1937 , the CIO chartered two national unions, the State, County, and Municipal Workers of America (SCMWA) and the United Office and Professional Workers of America (UOPWA), opening these unions to the rank and file social work unions. SCMWA sought to organize workers in all public agencies nationwide, while the UOPWA was chartered to organize office and professional workers in the private sector. Within a matter of months, existing social work unions within the AFL's AFSCME moved into both SCMWA and the UOPWA. Led by the powerful New York AWPRA union, by June of 1938 nearly one quarter of SCMWA's 35,000 members would represent employees in public welfare agencies in over a dozen states. Seven locals of the SSEU, most from the New York and Chicago locals would now comprise some 2,000 of the UOPWA's forty five thousand members. Only a small group of several hundred mid-western welfare workers remained within AFSCME. ${ }^{50}$

The move from the AFL to the CIO was not an easy one. Many unions, particularly the SSEU locals entering the UOPWA, faced new battles for employer recognition. Locals in Chicago, Philadelphia, New York and Los Angeles all waged protracted struggles for recognition. In June 1938 the New York City SSEU Local 19 made history when it successfully concluded the profession's first collective bargaining agreement with the National Council of Jewish Women. While the 
contract initially covered only some 25 employees, by the early 1940 s some 50 private agencies would have contracts with UOPWA locals. The success of the contract with the National Council of Jewish Women would be quickly followed by a UOPWA contract with the Russell Sage Foundation. ${ }^{51}$ SCMWA organizing within the public sector was more rapid and initially successful than that of the UOPWA. New SCMWA unions in New York, Chicago, Detroit, and Cleveland were able to win salary increases, reinstatements of dismissed workers, liberalized vacation and sick benefits, and establishment of grievance proceedings. Increasing the number of public case workers and reducing existing caseload standards were also major goals of the newly forming SCMWA, and between its unions in New York and Detroit alone, over 300 new positions were established and caseload reductions were achieved by a number of SCMWA locals. ${ }^{52}$

Backed by the growing power and resources of the CIO, SCMWA and its leader Abram Flaxer (formerly an official in AFSCME), and the UOPWA, directed by Lewis Merrill, continued to organize public and private social welfare agencies nationwide. Successful drives in Iowa, California, Minnesota, Kentucky, Washington, Missouri, and Indiana would continue to increase the union membership. By the end of 1939 some 36 SCMWA locals had been established nationwide in public welfare departments and SSEU membership in the UOPWA had increased to nearly $4,000 .^{53}$ The achievements of SCMWA and the UOPWA was not lost on CIO head John Lewis. Recognizing the initial success of his union's 
foray into social services, Lewis welcomed the rank and file into the CIO in a special message to social workers published in Social Work Today:

The Committee for Industrial Organization welcomes the addition of social workers to the ranks of organized labor in America...Social workers, whose daily task is to delve into the living conditions of America's poorer families, have an unequalled opportunity to inspect the social byproducts of our industrial system...The responsibility of and the opportunity of social workers are therefore two-fold. They have a responsibility to uphold the right of democratic organization among the workers with whom they come in daily contact, and they need the advantages of the same free, democratic organization for themselves. ${ }^{54}$

Lewis' enthusiasm for social work's entry into the CIO was shared equally by the rank and file. The CIO's emphasis on organizing industrial workers and its insistence on the development of vertical unions seemed at last to fit the vision of the movement's early advocates. Jacob Fisher, now president of the New York Social Service Employees Union (UOPWA), perhaps best summed up both the relationship of the rank and file to the CIO in 1938 and the movement's lessened political presence in the profession:

[Social workers] hoped to find in the CIO the kind of vigorous and imaginative leadership which they had looked for in vain in the A. F. of L. And they were not disappointed. The CIO took seriously the problem of organizing social work, as it took seriously the problem of organizing the steel industry. It spent money. It set up offices, hired organizers, issued literature and conducted meetings...

It is this absorption in the important task of building a solid smoothly running union with its feet on the ground that has made 1937-38 so different from other years. The past twelve months saw no manifestos issued, and no general appeals to the conscience of social work...The guiding principles have been and still are 
identification with labor through membership in trade unions and cooperative action between social work and the labor movement in the achievement of their common goals. The course of events this year dictated intensive self-organization as an integral part of this program. $^{55}$

As the decade of the 1930s was coming to a close, the rank and file movement had found a home in the CIO and had begun to repair the serious rift that had developed between it and the profession. But as storm clouds of war in Europe began to envelop the United States, the politics of the Popular Front would begin to break down and, once again, the movement would find itself at odds with the profession and its unions under attack from both within and without. 


\section{Notes to Chapter 5}

1. "Chicago hoists the flag," SWT (January 1938), p. 4.

2. Complete proceedings of the first national convention of rank and file groups in social work (1935), Jacob Fisher Papers, SWHA, Box 1, Folder 3.

3. Interview by author with Abram Flaxer, August 16, 1980. Flaxer was a top leader in AFSCME and later became head of the CIO's State, County and Municipal Workers of America.

4. National Coordinating Committee of Rank and File Groups in Social Work, Financial report for the period February 22, 1935 - February 17, 1936, Jacob Fisher Papers, SWHA, Box 1, Folder 5.

5. "Next steps in national coordination," SWT(July 1935), p. 16.

6. “A. F. of L. - mostly pro," SWT (February 1936), p. 26.

7. The American Federation of Labor and the social work employee: Report of the Cleveland Committee (1936), Jacob Fisher Papers, SWHA, Box 1, Folder 5.

8. Fifth session of the National Coordinating Committee's second rank and file conference (1936), Jacob Fisher Papers, Box 1, Folder 5; Complete proceedings of the 1936 convention of the National Coordinating Committee of Rank and File Groups in Social Work, Jacob Fisher Papers, SWHA, Box 1, Folder 5.

9. “A. F. of L. - mostly pro," $S W T$ (February 1936), p. 26; "Trade union notes" [NCC mimeograph distributed at 1937 NCSW] (May 23, 1937), Jacob Fisher Papers, SWHA, Box 1, Folder 6.

10. "Swing to the A. F. of L.," SWT (April 1936), pp. 3-4.

11. "Rank and file," $S W T$ (November 1936), p. 26; "Rank and file," SWT (December 1936), p. 24; Fisher, The response of social work to the Depression, p. 163.

12. "Rank and file," SWT (February 1937), p. 24; Fisher, The response of social work to the Depression, p. 164. Despite the official termination of NCC control of Social Work Today, the editorial staff continued to consist of union officials and supporters representing a significant portion of the union movement.

13. Articles in the May 1936 journal included: Harry Lurie, "Quitting the relief business," pp. 5-7; Lenore Bartlett, "The attack on the Townsend Plan,” pp. 11- 
12; Celeste Stack, "Youth demands a chance," p. 13; Wade Albright, "Roosevelt's back to the land program," pp. 15-18; and Joan Frey, "Aliens on relief," p. 18.

14. Harry Lurie, "Quitting the relief business," SWT (May 1936), pp. 6-7.

15. The 1936 Platform of the NCC, Jacob Fisher Papers, SWHA, Box 1, Folder 5.

16. "Social work's stake in the election," SWT(October 1936), p. 4.

17. "Now that the election is over," SWT (December 1936), p. 3.

18. "Congress and social work," SWT (February 1937), pp. 3-5.

19. "We support the President," SWT (April 1937), p. 3.

20. “Roosevelt's program for recovery," SWT (May 1938), p. 4.

21. "Labor unity and the 1938 elections," SWT (June 1938), p. 4.

22. For example, see: Simon Breines, "Uncle Sam clears a slum," SWT (March 1937), pp. 7-8; James Hubert, "Needs of Negro children," SWT (April 1937), pp. 13-15; "Running out on the unemployed," SWT (June 1937), p. 3; Maxwell Stewart, "Where are the jobs, Mr. Hopkins?," SWT (October 1937), pp. 5-6; Janet Feder, "Youth's own agency," SWT (April 1938), pp. 19-20; and Paul Sann, "Can we discard the WPA?," SWT (January 1938), pp. 3-5.

23. "The New Deal is our deal," $S W T$ (June 1939), p. 38.

24. Abram Flaxer, "The social worker as a servant of the people," SWT (June 1938), p. 31 .

25. Dimitroff, The united front; Klehr, The heyday of American Communism, pp. 167-171.

26. Ibid.

27. Quoted in Klehr, The heyday of American Communism, p. 177.

28. Ibid., pp. 176-80. 
29. Starobin, American Communism in crisis, pp. 35-36; Isserman, Which side were you on?, pp. 12-14; and Klehr, Ibid.

30. Minutes of the Seventh Convention of the Communist Party, Archives, Communist Party USA.

31. Klehr, The heyday of American communism, pp. 186-222; George Chaney, $A$ long journey (Chicago: Quadrangle Books, 1968), pp. 50-82; David Caute, The fellow-travelers: Intellectual friends of communism (New Haven, CT: Yale University Press), pp. 141-195.

32. Interview by author with Jacob Fisher, February 12, 1981; interview by author with George Wolfe, July 3, 1980; interview by author with Abram Flaxer, August 16, 1980; Klehr, Ibid., p. 235; Bertha C. Reynolds Papers, American Institute for Marxist Studies; Bertha C. Reynolds Papers, Sophia Smith Collection, Smith College, Series IV, Box 11, Folder \#123.

While there is no evidence that van Kleeck was ever a member of the party, her value to the party as a source of public support for their programs was clear. On more than one occasion the party put forth her name to the Comintern as a respected public figure who could promote the party's programs. See: Klehr, Haynes, and Anderson, The Soviet world of American communism, pp. 78-80; 83-84; 302-306.

33. Interview by author with Jacob Fisher, February 12, 1981.

34. “A plea for understanding," SWT (June 1936), p. 4.

35. Ibid.

36. Ibid.

37. Albert Comanor, "The AASW thinks aloud," $S W T$ (November 1937), p. 16. See also, Clara Rabinowitz, "The AASW drafts another program," SWT (April 1937), pp. 5-6.

38. Milton Cohen, "Protecting professional standards," SWT (May 1938), pp. 15-16.

39. "Case work notebook," SWT (October 1936), pp. 23-24. Block quote from page 24.

40. "Case work Notebook," SWT (May 1937), pp. 21-22; "Case work notebook," SWT (February 1938), pp. 21-22; "Case work Notebook," SWT (January 1940), 
pp. 23-24; "Case work Notebook," SWT (March 1940), pp. 23-24; "Case work notebook," SWT (April 1940), pp. 23-24.

41. "On the organizational front," $S W T$ (June 1937), pp. 6-7.

42. David Kaplun and Karl de Schweinitz, "Needed: In-service training," $S W T$ (December 1938), pp. 9-10; Marion Hathway, "The right to training," SWT (October 1937), pp. 11-12. Quote from page 11; Marion Hathway Papers, SWHA, University of Minnesota.

43. Grace Coyle, "Group work and social action," SWT (November 1937), pp. 13-15.

44. Wayne McMillen, "Trade unionism for social workers," SWT (April 1937), pp. 7-9.

45. Dorothy Kahn, "Cleveland - and points East, West, North and South," SWT (January 1940), pp. 13-14.

46. Grace Marcus quoted in Fisher, The response of social work to the Depression, $\mathrm{p}$. 170. See also: Grace Marcus, "Sigmund Freud: An appreciation," SWT (November 1938), p. 6; and Grace Marcus, "Changes in the theory of reliefgiving,” SWT (June-July 1941), pp. 6-9, 29.

47. Virginia Robinson quoted in Fisher, The response of social work to the Depression, p. 171.

48. Boyer and Morais, Labor's untold story, pp. 274-277; Robert Zieger, The CIO, 1936-1955 (Chapel Hill: University of North Carolina Press, 1995), pp. 16-21; Irving Bernstein, The turbulent years: A history of the American worker 19331941 (Boston: Houghton Mifflin, 1970) pp. 37-91.

49. Bernstein, Ibid., pp. 695-699; Zieger, Ibid., pp. 66-93.

50. Jacob Fisher, "One year of the CIO in social work," SWT (June 1938), pp. 21-23; Jacob Fisher, "Forward with the C.I.O.," SWT (October 1937), pp. 8-9; Daniel Allen, "C.I.O. for public agencies," SWT (October 1937), pp. 9-10.

51. Ibid;; Alexander, Organizing the professional social worker, p. 160-163.

52. Wenonah Nedelsky and Marc Johnson, "Things grown in California," $S W T$ (December 1937), pp. 11-12; Fisher, The response of social work to the Depression, p. 187; Interview by author with Abram Flaxer, August 16, 1980. 
53. Ibid.

54. John L. Lewis, "Welcome to the ranks of labor," SWT (January 1938), p. 8.

55. Fisher, "One year of the CIO in social work," SWT(June 1938), p.21, 21-22. 


\section{CHAPTER 6:}

\section{REPRESSION, RESISTANCE AND DESTRUCTION: THE FINAL YEARS ...just a racket, a Communist controlled racket. ${ }^{1}$}

As rank and file unions representing social workers in the CIO continued their organizing efforts and slowly attempted a rapprochement with the mainstream profession in the late 1930s, the convergence of foreign and domestic events would soon unravel both efforts and refocus enmity upon the movement. Once again, as in the days of the Popular Front, the movement's apparent adherence to the twists and turns of the Communist Party's political line would come under question in the wake of the 1939 non-aggression pact between Germany and the Soviet Union. The apparent closeness between the movement and the Communist Party would place the movement at odds with the profession and evoke aggressive attacks upon rank and file unions by state and federal officials seeking evidence they were controlled by the party. While temporarily abated during World War II, the attacks of anti-Communist investigators upon the rank and file unions, coupled with the acquiescence of the mainstream profession in the face of these attacks, would eventually lead to the destruction of both the unions and the movement as a whole.

\section{Peace, Collective Security and the Politics of the Popular Front}

Throughout the 1930s, both the rank and file movement and the mainstream profession shared alarm over the rise of fascism in Europe. Indeed, following the consolidation of the Nazi regime in Germany in 1933, many Americans, including 
social workers, called for the United States to form an alliance of collective security with the Soviet Union to forestall the spread of fascism. ${ }^{2}$ Most strident in these calls was the American Communist Party, which denounced U.S. isolationist policies and characterized the Chamberlain government in England and the government of France as containing fascist tendencies threatening to world democracy. In particular, the Communist Party called upon progressive organizations and its allies in the Popular Front to defend the Soviet Union from possible Nazi aggression through their support of a collective security pact between Russia and the United States. ${ }^{3}$

Calls for collective security became the centerpiece of rank and file unions' foreign policy positions during 1937 and 1938 as reflected in both the speeches of its leaders and in resolutions passed by the SCMWA and UOPWA locals and the national CIO. ${ }^{4}$ While support of calls for collective security was generally favorably reported on in mainstream social work journals such as the Compass and Survey, Social Work Today most vigorously argued the case for a collective security pact. Condemning the policy of neutrality pursued by the Roosevelt administration, the journal's editors took up the cause of alliance with the Soviet Union in November, 1937, declaring that, "There is an inherent weakness in the democratic-pacifist reaction to the choices with which nations are faced this day. Soviet Russia has been calling attention to this weakness at every opportunity."5 The journal's editors called upon the Roosevelt administration to repeal the Neutrality Act, which prevented the purchase of war materials by Spain and China, and supported a boycott of Japanese products. Invoking the spirit of internationalism, one contributor to the journal 
exhorted social workers to ally with clients, unions and peace organizations to

protect freedom and the "provision of bread and security"

The links in the collective striving for bread-peace are international. The Spanish loyalists are at the barricades for us all. We respond to the International Brigade and with the North American Committee to Aid Spanish Democracy. Worker elements in the present Chinese struggle think of the Japanese worker-soldiers, not mainly as enemies, but potential allies. This has far-stretching implications. When social workers face war, they face in fact an epochal situation, pregnant with a new life. ${ }^{7}$

By early 1938, Social Work Today's demands for collective security intensified amidst Communist Party denunciations of reactionary elements in the governments of England and France. In an editorial in its April, 1938 edition, Social Work Today's editors warned its readers that “....international anarchy and world fascism" was at hand in the absence of U.S. support of collective security. ${ }^{8}$

Declaring that social workers wanted peace, the editors urged its readers to demand that the U.S. government actively support anti-fascist struggles in Europe and Asia:

We are all too well aware of the treasonous cynicism of the English fascist, Chamberlain; of the indecisiveness of the French Popular Front foreign policy; of our own vacillation between international statesmanship and isolationism. But today is not the time for people with a social conscience, with devotion to a democratic and peaceful world, to sigh and bite their nails...There is a remedy. There is one remedy. That remedy is collective security...SOCIAL WORK TODAY calls upon every one of its readers to become an active and determined worker for peace and democracy through collective security. It is the most important task confronting the world today. ${ }^{9}$ (emphasis in the original)

The journal's calls for collective security were also accompanied by warnings that cooperation alone might not prevent world war. In this regard, the journal's editors 
supported a "positive peace policy" of containment that, if resisted by fascist governments, included a call for American military response: "If war-makers respond to this peace action with war, they must be defeated with war."10

While the mainstream of the profession generally shared Social Work Today's calls for collective security, the position of the journal and that of the rank and file unions regarding the appeasement policies of the British and French governments, and their outspoken admiration of the Soviet Union, were less popular. In contrast to Social Work Today's support of preparations for war, many leaders of the profession and its mainstream journals viewed the origins and solutions of the international crisis as primarily economic in terms, believing that ensuring freedom of trade among democratic countries would contain the spread of fascism. Both Paul Kellogg, editor of Survey, and John Gavit, editor of Survey Graphic, supported this more moderate stance. Kellogg and Gavit, while supporting the concept of collective security, believed that the assurance of free trade among democratic countries and the concomitant restriction of trade with fascist governments could avert a world-wide conflict. ${ }^{11}$ Likewise, the National Federation of Settlements and local chapters of AASW supported changes in the Neutrality Act to allow the sale of arms of Spain and China, as well as condemning trade with Germany and Japan. ${ }^{12}$ Solomon Lowenstein, president of the $1939 \mathrm{NCSW}$, also represented the views of many in the mainstream of the profession who opposed U.S. intervention in the war in Europe. Lowenstein eschewed support of either collective security or isolationist 
policies but agreed with Kellogg and Gavit that properly applied trade policies could avert war. ${ }^{13}$

Of greater importance, perhaps, than the differences over the meaning of collective security between the rank and file movement and the profession, was the movement's unabashed support of the Soviet Union. Here, clear differences between the mainstream of the profession and the rank and file manifested themselves. Throughout the late 1930s, many of the mainstream profession's leadership increasingly saw no significant distinction between what they considered the totalitarianism of both fascism and communism, a comparison strongly disputed by Social Work Today and many leaders of rank and file unions within the UOPWA and SCMWA. ${ }^{14}$ While such differences rarely surfaced publicly, the apparent sympathies of the movement towards Soviet-style communism would later estrange it from the mainstream profession and divide the movement itself in the wake of the Nazi-Soviet pact of non-aggression.

Despite the growing differences between the rank and file and the profession on the matter of collective security, both found common ground in the case of the Spanish Civil War. In 1936, pro-fascist elements of the Spanish military under the command of general Francisco Franco revolted against the leadership of the newlyelected leftist government. From the onset of the civil war until the defeat of the government in 1939, the cause of the Spanish loyalist government received the sympathetic support of U.S. liberals and progressive organizations. The Communist Party would soon become the focal organization rallying support for the loyalists, 
holding up the civil war as an example of the betrayal of western democracies through their policies of neutrality. The party was instrumental in organizing numerous organizations to support the loyalist cause, including the Spanish Aid Committee, the American Friends of Spanish Democracy and the Abraham Lincoln Brigade, one of several volunteer units of Americans organized by the Communist Party that fought on the loyalist side in Spain. ${ }^{15}$

The cause of the Spanish loyalists temporarily united both the rank and file and the liberal wing of the mainstream profession. Social work radicals and union leaders, such as Mary van Kleeck, Roger Baldwin, Lewis Merrill and Abram Flaxer, as well as liberal social workers such as Paul Kellogg and Grace Coyle, joined a long list of academics, artists, writers and union officials in an open letter to President Roosevelt supporting the lifting of the U.S. embargo against selling arms to Spain. ${ }^{16}$ Rank and file unions and AASW chapters alike supported the formation of the Social Workers Committee to Aid Spanish Democracy, a subsidiary organization of the American Friends of Spanish Democracy. Once again, rank and file social workers such as van Kleeck, Bertha Reynolds, Jacob Fisher and Joseph Levy, as well as liberals such as Paul Kellogg, Gordon Hamilton, Owen Lovejoy and Lillian Wald, joined ranks as members of the committee's Executive Board. ${ }^{17}$ Throughout the course of the civil war, the Committee would raise funds for medical supplies, the construction of hospitals, and the care of refugees. In addition to fund raising, several delegations of social workers led by Committee member Constance Kyle 
made trips to Spain to identify needs and hold fund-raising meetings in the United States upon their return. ${ }^{18}$

For some social workers in the rank and file movement, mere financial or moral support of the loyalist cause would not suffice. In June, 1937, a small notice in Social Work Today announced:

\section{In Memoriam \\ Julius Rosenthal}

Social worker, active trade unionist in the Association of Workers in Public Relief Agencies, friend of SOCIAL WORK TODAY, volunteer in the Abraham Lincoln Battalion with the Loyalist forces in Spain: killed while fighting Fascism that Democracy might live - April, $1937^{19}$

While the number of social workers who fought and died in the civil war are unknown, Julias Rosenthal was the first so recorded, symbolizing in his death the depth of commitment the rank and file placed in defeating fascism. ${ }^{20}$

\section{From Collective Security to "The Yanks Are Not Coming"}

The calls of Social Work Today and the rank and file unions of the SCMWA and UOPWA for the United States to shed its neutrality continued unabated through the summer of $1939 .^{21}$ As Franco was poised to claim victory in the civil war in Spain, Social Work Today lamented the collapse of the loyalist forces, attributing its defeat to the failures of the western democracies:

[Spain is] a victim, like Austria and Czechoslovakia, to the connivance of the pro-fascist heads of the British and French governments with the deadly enemies of democracy. In this betrayal the United States has played its part by a 'neutrality' which denied the Spanish government its right to purchase the means of defense... ${ }^{22}$ 
But events in August 1939 would suddenly and dramatically alter the movement's strident calls for an end to U.S. neutrality. On August 23, 1939, Germany and the Soviet Union announced the signing of a non-aggression pact between the two countries, sending shock-waves of disbelief throughout the left-progressive community in the United States and much of the world.

In the United States, the Communist Party was caught equally unawares by the announcement of the pact's signing. Prior rumors of such an impending pact had been met with scorn by the party, prompting party leader Earl Browder to compare the chances of such an agreement as less likely than his election to the office of President. ${ }^{23}$ Now, the party was in disarray as it sought to both understand the reasons for the pact and explain this sudden change in Russian policy to its members and its allies within the Popular Front. In early September, the party's Political Commission met to decide on a course of action. Within less than a month, from the signing of the pact to the conclusion of the Commission's deliberations, the party's vigorous campaign for collective security was replaced with a new call: "Keep America out of the Imperialist War!"24 Reversing course, the party now declared that the war in Europe was imperialist in origin and should be opposed by the American people:

The war that has broken out in Europe is the Second Imperialist War. The ruling capitalist and landlord classes of all the belligerent countries are equally guilty for this war.

This war, therefore, cannot be supported by the workers. It is not a war against fascism, not a war to protect small nations from 
aggression, not a war that workers can or should support. It is a war between rival imperialisms for world domination. The workers must be against this war. ${ }^{25}$

The sudden shift of the Communist Party from demands for collective security to a call for isolationist policies was accompanied by new attacks by the party upon the Roosevelt administration and previous allies in the Popular Front that refused to agree with the party's new line. ${ }^{26}$ The impact of this sudden policy reversal by the party devastated much of the respect and prestige it had earned during the earlier years of the Popular Front. Over the course of the next two years, membership in the party would decline dramatically, as would the membership of many Popular Front organizations closely associated with the Communist Party. Indeed, the party's premiere ally, the American League for Peace and Democracy, with an estimated membership of 20,000 in August of 1939, lost over 1,000 members per month until its disbanding in 1940. Other organizations close to the party suffered similar losses, including the American Student Union, the League of American Writers, The League for Peace and Democracy and American Friends of the Soviet Union. ${ }^{27}$

While much of the liberal community within and outside of social work recoiled with distaste in reaction to the Communist Party's reversal of political line in the weeks following the signing of the non-aggression pact, the unions represented by the SCMWA and UOPWA, as well as Social Work Today, quickly revised their own line, now declaring that the war in Europe was purely inspired by the imperialist policies of the western democratic governments. ${ }^{28}$ In its first issue following the announcement of the non-aggression pact, Social Work Today published a special 
editorial, entitled "The War and the New Deal."29 Dropping their previous calls for collective security, the editors now declared that the programs of the New Deal could only be defended by a policy of peace and neutrality:

The answer to us is clear. The basic things which America can offer the world today are a strong prosperous, democratic social organization and a foreign policy consistent with it...The New Deal march toward social progress must be intensified. Unification there must be, yes, but it must be unification around satisfied need. The other kind of 'unification' - clinging to the status quo, a status of social injustice - leads straight towards mass discontent, toward disillusionment with democracy, toward war as a panacea. ${ }^{30}$

To defend this "march" of the New Deal, Social Work Today now advised its readers that social workers must make America “...a force for peace" and "...prevent our being dragged into a war of which we want no part..."31

Refining its switch in position from one of collective security to one of strict neutrality, in January, 1940, Social Work Today drew up a statement of principles, "Meeting Social Need: A Peace Program."32 Declaring that it was time for social workers "...to speak out for the maintenance and extension of social progress" and "point out the dangers of war propaganda," Social Work Today's editors articulated a program calling for the protection of social gains at home through a resistance to war. ${ }^{33}$ The Peace Program statement detailed seven principles for peace and continued social progress: 1) the protection and expansion of basic social welfare program; 2) the prevention of diversion of social welfare funds to the military; 3) resistance of the administration of social and civil services by the military; 4) the public redistribution of government profits obtained through the sale of arms to 
foreign governments; 5) the protection of civil rights and the continued rights of unions to collective bargaining; 6) the commitment of the profession to the maintenance of peace; and 7) an intensified alliance between the profession and community organizations in support of peace and the protection of democratic rights. ${ }^{34}$ Tapping the anti-war sentiment widely prevalent in the field, the principles were endorsed by over 75 national and local leaders in the profession, including leaders of the UOPWA and SCMWA unions and rank and file supporters such as Mary van Kleeck, Harry Lurie and Bertha Reynolds. In addition to the movement's expected supporters, leaders in the mainstream of the profession, including Dorothy Kahn, Gordon Hamilton, Paul Kellogg and Karl de Schweinitz, also endorsed the statement of principles. ${ }^{35}$

While the support of Social Work Today's Peace Program by many in the mainstream of social work reflected a genuine opposition to American entry into the war within the whole of the profession, many of the statement's signatories questioned the journal's seemingly mirrored stances of the Communist Party, particularly the journal's condemnation of England as a main instigator of imperialist war and its opposition to U.S. aid to the British government. ${ }^{36}$ To buttress the journal's position, Mary van Kleeck attempted to explain to readers the reasoning behind the non-aggression pact and make the case for understanding war in Europe as a fundamental expression of imperialism. Arguing that the non-aggression pact was necessary in the face of the Soviet Union's inability to rely on the League of Nations and the Chamberlain government to ensure a pact of collective security 
against Germany, van Kleeck maintained that the German-Soviet pact had effectively blunted further imperialist ambitions of the British and French. For American social workers, van Kleeck argued that "...our position in the world crisis must therefore be one of constructive neutrality, independent of the conflicts which do not concern us, but demanding that they be subordinated to the human interests implied in all our work."37

Trade unions representing social workers in the CIO also took up the banner of non-intervention, joining with the anti-war sentiments of CIO chief John Lewis, whose fear of U.S. intervention led him to briefly consider the launching of a third party to oppose Roosevelt in the 1940 elections. As the CIO passed resolutions against U.S. intervention at its national convention, Lewis made labor's case for nonintervention:

Involvement or intervention in the European war is repugnant to every healthy-minded American. The American electorate is anxious to demonstrate this fact in the political election of 1940. The major political party that permits war, or potential war profiteers, or professional politicians with an aggressive military complex, to dominate or write its platform will find itself hopelessly beaten by the votes of an outraged electorate in November. ${ }^{38}$

National conventions of both the SCMWA and UOPWA passed resolutions opposing intervention and, condemning what the unions considered a rising tide of war hysteria fanned by the Roosevelt administration, called on its members to defend social welfare programs from possible conversion into programs for military preparedness. ${ }^{39}$ But unlike the CIO's Lewis, leaders of the SCMWA and the 
UOPWA enthusiastically embraced the Communist's "The Yanks Are Not Coming" slogan, forming hundreds of local union "The Yanks Are Not Coming" and "Peace" committees during early 1940, including over 70 such committees in New York City alone. $^{40}$ The Joint Committee of Trade Unions in Social Work (JCTU), a coalition of SCMWA and UOPWA unions, carried the movement's peace message to the 1940 NCSW conference held in Grand Rapids, Michigan. There, members of the JCTU obtained over 1,000 signatures from delegates in support of Social Work Today's Peace Program statement and sponsored sessions warning social workers of the dangers of U.S. involvement in the war in Europe. ${ }^{41}$

Throughout 1940 and early 1941, the pages of Social Work Today increasingly emphasized the need for social workers to support U.S. neutrality. Reversing its earlier support of the New Deal during the days of the Popular Front, the journal renewed its criticisms of Roosevelt and the inadequacies of the New Deal. Editorials and articles condemned reductions in the WPA and the militarization of the CCC and other federal work projects as the journal's editor, Frank Bancroft, warned of an increasing deflection of social welfare programs into war preparedness programs:

It is my firm conviction that rational understanding of what is happening around and to the social services, and determined action on the basis of such understanding, are the primary needs of all of us in social work at the this moment. Federal social services, deflected from their proper objective of dealing constructively with permanent social programs, are being integrated into the national defense program. This is being done as an organic part of a governmental policy supported by the worst enemies of these 
programs, of substituting a war economy for the consumers' economy toward which...the New Deal was directed. ${ }^{42}$

Bancroft went on to clearly articulate the journal's main thesis, reminiscent of its charges of New Deal social fascism in the early 1930s: "True American patriotism today lies...in the determination that America will be the first great power to deal successfully with its domestic fascism in time to prevent war...fascism cannot be fought by fascism, but must be fought by its opposites - liberty and security.",43

Despite the anti-war sentiments expressed by delegates to the $1940 \mathrm{NCSW}$ and the AASW's delegate assembly, as U.S. entry into the war seemed increasingly likely, by late 1940 many in the mainstream of social work, unlike Social Work Today and the CIO trade unions representing social workers, moderated their previous pacifism and moved to support war preparations. In September 1940, the New York State chapter of the AASW formed a Committee on the Social Aspects of Defense, and the national AASW Committee on Government and Social Work also began deliberations on the role of the profession during times of war. Noting these developments with alarm, Social Work Today warned that the AASW "...might act as convenient messengers from the military to the civil and social side of American life, rather than as professionally skilled ambassadors from the people...,44

While significant numbers of the AASW and its leadership continued to prepare for the possibilities of U.S. entry into the war, Social Work Today intensified its calls for neutrality and defense of domestic social welfare programs. In its final issue before the German invasion of the Soviet Union in June, 1941, Social Work 
Today made a special appeal to social workers attending the 1941 NCSW, presenting what it called a "People's Program in 1941":

Today social workers find themselves in serious conflict because of the severity of the impact of the present war program upon the people's program of democratic social advancement. It is increasingly difficult for them to face resolutely the fact that the war program is not the people's program....

The American people have the wit and the courage to organize themselves for peace more effectively than they have been organized for war...Today, in a dozen ways, they are organizing for themselves a life of peace, freedom and security. ${ }^{45}$

As word of the Nazi invasion of the Soviet Union reached the American Communist Party on June 22, 1941, yet another shift in its foreign policy line would soon be forthcoming for both the party and the rank and file movement. On June 28, the party's National Committee silently abandoned its previous characterization of the war in Europe as an imperialist war, now calling upon the American government to support military efforts to defeat fascism. ${ }^{46}$ Once again, the editorial line of Social Work Today would reflect this sudden shift from neutrality to war preparation. In its first issue published after the Nazi invasion, Albert Deutsch explained the new set of circumstances facing progressive social workers and their unions:

One simple, inescapable fact pounds upon our social thinking today: we're in a war. It's no longer a war of words, but an honest-to-goodness shooting war, a war between two mutually incompatible worlds - democracy and fascism...Social workers, as such, have as large a stake in victory as nay other single group in the population, for fascism is the annihilation of social work...

This is no phony war...We've watched a monster follow its destructive path for eight years...We must kill it or be killed...This 
is a good time to be a social worker - for those who can take it.

Let's go. ${ }^{47}$

Trade unions representing social workers also altered their political line following the German invasion. Delegates to the 1941 SCMWA Second Biennial Convention endorsed the Roosevelt administration's provision of aid to the Soviet Union and Britain. Addressing the convention, SCMWA president Abram Flaxer, who months previous had condemned U.S. war preparations, now pledged its membership would support the government's preparations "...for all out aid to the war efforts of those nations now engaged in the war to wipe out the menace of Hitlerism." With the Japanese bombing of Pearl Harbor on December 7, 1941, the shift of the rank and file unions and their voice, Social Work Today, was complete. Declaring in its January, 1942 issue that "...the job of our field of work a major instrument in victory," the journal now identified its "essential task" as “...articulating the most progressive and imaginative social and professional thinking of our field around social mobilization."49 Like Social Work Today, the SCMWA and UOPWA also pledged the full support of its member unions in the war effort and joined the CIO national leadership in backing a no-strike policy for the duration of the conflict. ${ }^{50}$ Beset by financial debt and its staff now drawn away by the war, the February, 1942 issue of Social Work Today would be its last, its final article perhaps appropriately authored by Bertha Reynolds:

We know there will be blood, sweat and tears. We know there will be new heights of heroic devotion. We know that the united will of the people will not lose. We know that grim realities like guns and tanks and airplanes will make possible - or fail to make 
possible - the intangibles like human brotherhood really lived out, creative achievement, peaceful work, love and worship. We are resolved that the battle of production, grim as it is, shall not fail, and the clash of arms shall not cease until the world is safe from pestilent terror and free men can shape their destiny. ${ }^{51}$

\section{Red Scares, War, and a Cold War: The Demise of the Rank and File Movement}

As the tortured twisting of foreign and domestic policy lines continued throughout 1940 and 1941 in the pages of Social Work Today and in the resolutions of CIO unions most closely linked to the Communist Party, particularly the SCMWA and UOPWA, both the journal and the unions soon came under attack for alleged communist domination by elements within the profession, conservative forces within the $\mathrm{CIO}$, and state and federal subversive investigation committees. While the rank and file trade unions and Social Work Today briefly seemed to be assuming a leadership role in their promotion of the Peace Program, supported by so many at the 1940 NCSW, by 1941, charges of communist domination of the journal and trade unions representing social workers began to surface within the profession. Most prominent in these attacks was the Social Work Trade Unionists for Britain and Democracy committee, headed by John Fitch. Accusing the rank and file unions of being dominated by Communists, the committee distributed mimeographed papers to leaders of the profession and delegates to the $1941 \mathrm{NCSW}$ elaborating on their accusations. ${ }^{52}$ Tracing the evolving political line of Social Work Today through October of 1940, the committee charged the journal in its first paper with consistently being in accord with the Communist Party: 
The above [analysis] of Social Work Today editorial policy speaks for itself. In both domestic and foreign affairs the journal has consistently taken a stand which parallels the C.P. line, has employed the same arguments, and has, therefore, shown that its present isolationist concern cannot be regarded as a logical result of intellectual conviction. ${ }^{53}$

A second mimeographed attack on Social Work Today was distributed by the committee in June of 1941. Tracing the journal's continuing shifts in foreign and domestic policy, the paper reasserted its claim that the journal and officials of the SCMWA and UOPWA were aligned with the Communist Party, taking pains to list the names of no less than 46 individuals who were staff or sponsors of the journal. ${ }^{54}$ The committee continued its attack at the 1941 NCSW conference, distributing a flyer accusing the SCMWA and UOPWA of being tools of propagandists opposed to enemies of totalitarianism. The increasing agreement of many within the profession that the rank and file unions were suspect was, indeed, indicated by some 80 signatures of support on the flyer, many of whom had signed the Peace Program statement of a year ago. ${ }^{55}$

The growing tendency within the mainstream of the profession to associate the rank and file unions with the purported totalitarian politics of the Communist Party reflected a growing consensus within the whole of the American liberal community during 1939 and 1940 that both communism and fascism were equally dangerous threats to democracy. Following the Communist Party's reversal of its political line after the signing of the Nazi-Soviet non-aggression pact, liberal-left publications such as The Nation and the New Republic now condemned the party and 
its supporters as untrustworthy and subservient to the interests of the Soviet Union. ${ }^{56}$ As a growing consensus of anti-Communism developed among liberals, many liberal-left organizations began adopting so-called "CommuNazi" policies during 1939 and 1940, denying membership to and expelling suspected members of the Communist Party and fascist organizations. ${ }^{57}$ Reflecting the rising tide of liberal anti-Communism, Survey Graphic published several articles equating the dangers of communism with fascism, including an appeal by Archibald MacLeish for liberals to reject the Communist Party's policy of anti-fascism and instead "...adopt the policy of aggressive pro-democratic action.... ${ }^{, 58}$ Even Harry Lurie, a formerly stalwart ally of the rank and file unions, began to turn away from the movement's defense of the Soviet Union and its perceived allegiance to the Communist Party. Stung by the Moscow trials and the Nazi-Soviet pact, Lurie rejected association with the Communist Party and criticized Social Work Today editor Frank Bancroft for the magazine's "...tendencies in the administration of the magazine that are inclined to be dogmatic and inflexible in character," and warned Bancroft that "...should SWT become increasingly orthodox and rigid in its point of view, I believe that I, for one, would begin to lose interest in it since I don't believe in the finality of truths and revelations..."59 The extent of disenchantment of some within the rank and file movement regarding its Communist members was further dramatized by the rejection of Communist association by Roger Baldwin. Once one of the movement's most strident and radical intellectual leaders, by 1940, Baldwin now considered Communism as equal a danger as fascism. Baldwin, Executive Director of the 
American Civil Liberties Union (ACLU), joined with liberal anti-Communist Executive Board members in 1940 to expel board member Elizabeth Gurley Brown, an open Communist and member of the party's National Committee. Brown's eventual expulsion was strongly opposed by ACLU board member Mary van Kleeck, who resigned from the board and subsequently broke off relations with Baldwin, just as Baldwin severed his ties with the rank and file movement. ${ }^{60}$

While allegations of Communist domination of the rank and file unions increased during 1940 and 1941 within the profession, rank and file alarm over such accusations was quickly superceded by the formation in the early 1940s of state and federal subversive activities committees investigating Communist subversion in labor unions and other organizations throughout the country. ${ }^{61}$ As fears of Communism began to share an equal footing with the dangers of fascism, in 1939 the Roosevelt administration began to take steps against the Communist Party, conducting numerous investigations into the activities of the party and arresting party leader Earl Browder on charges of passport violations. ${ }^{62}$ In Congress, antiCommunist legislators passed the Alien Registration Act, popularly referred to as the Smith Act, requiring the registration of all non-citizens with the government and providing for the deportation of aliens shown to be members of revolutionary political organizations. Included in the provisions of the Smith Act was a sedition clause, establishing the act of teaching or advocating the overthrow the government as a federal crime. Under the provisions of this new sedition law, mere membership in an organization promoting such acts was sufficient for conviction. Adding to the 
provisions of the Smith Act, the 1940 Congress also passed the Voorhis Registration Act, required all organizations "subject to foreign control" to register with the Department of Justice. ${ }^{63}$ Even prior to the passage of the Smith Act and the Voorhis Registration Act, Congress had authorized the creation of the House Un-American Activities Committee in 1938. Under the leadership of Martin Dies, an ardent opponent of the New Deal and staunch anti-Communist, HUAC was empowered to investigate communist and fascist influence in suspected organizations as well as allegations of such infiltration in government agencies. ${ }^{64}$

As the HUAC launched a series of investigations into fascist and communist subversion in the late 1930s and early 1940s, so-called Little Dies committees were similarly authorized by several state legislatures. While the HUAC had concentrated its investigations on communist subversion in New Deal projects such as the Federal Writers Project, the Federal Theatre, and the CCC, as well as organizations such as the Farmer-Labor Party and the ACLU, many of the state-initiated subversive activities committees focused on public relief unions in their investigations of communist subversion. ${ }^{65}$ The most ambitious of these Little Dies committees would surface in California, where the Assembly Relief Investigating Committee, under the chairmanship of Samuel Yorty, was authorized by the legislature to investigate alleged communist infiltration into the State's Relief Administration (SRA) ${ }^{66}$ Declaring that the SCMWA, the union representing relief workers, was under the control of the Communist Party, the committee held a series of investigatory hearings throughout California in 1940. In the wake of the investigations, numerous 
SCMWA members were arrested on charges of contempt by the committee, and a wholesale purge of SCMWA members in the SRA began. In Alameda, over 30 workers were dismissed, including the entire executive board of the local union, and 18 employees of the Stockton SRA office arrested for defying the investigating committee were subsequently dismissed. SRA offices in Los Angeles, Visalia, and San Francisco witnessed similar dismissals of union leaders and members, severely weakening SCMWA. ${ }^{67}$ The committee's attacks on SCMWA were accompanied by similar attacks on unions and their members within private agencies. In Los Angeles, members of the SSEU local of the UOPWA were dismissed on charges of inefficiency and subversion by the Jewish Social Service Bureau, and the union battled to maintain its right to collectively bargain on behalf of its members. Members of the UOPWA were also accused of being communists by the Yorty committee and its successor, the Tenney Committee, in San Francisco, Los Angeles, and San Diego as the SSEU locals struggled to maintain their membership. ${ }^{68}$

The investigations of SCMWA and UOPWA in California were replicated in various degrees by subversive activities committees in other states. In Pennsylvania, over 50 employees of the Philadelphia County Board of Public Assistance, including the entire executive board of the local SCMWA, were fired over charges of association with the Communist Party and violations of the Hatch Act (prohibiting political activity by government employees) following hearings of the Dies Committee into communist influence in Philadelphia. ${ }^{69}$ In addition to investigating the SCMWA, the Dies committee focused its attention on Social Work Today and its 
National Committee of Cooperators, a fundraising group that included Bertha Reynolds, Mary van Kleeck, Abram Flaxer, Lewis Merrill and others. After hearing testimony on the journal, the committee declared the journal a "Communist Front" publication and added its supporters to its lists of communist sympathizers. ${ }^{70}$ In Newark, New Jersey, local leaders of the SCMWA were accused by the local relief agency of being communists and summarily dismissed without hearings, almost breaking the union..$^{71}$ Similar investigations in Michigan, Texas, Illinois, and Maryland also targeted the SCMWA and UOPWA, resulting in dismissals of union leaders and activists for alleged communist subversion, seriously undermining union gains made over the previous years. ${ }^{72}$

As unions representing rank and file social workers reeled under the assaults of government investigations, they came under equal attack by anti-Communist elements within the CIO. While the presence of Communist Party union organizers in the initial organization of the $\mathrm{CIO}$ had been tolerated and even solicited by $\mathrm{CIO}$ president John Lewis, Lewis' toleration was based on a recognition of party organizational skills as opposed to any agreement with the party's politics. ${ }^{73}$ During the late 1930s, an uneasy alliance between Lewis and the Communist Party was maintained, primarily due to Lewis' opposition to Roosevelt, who Lewis feared was leading the nation into a world war. Lewis' opposition to Roosevelt, and his handsoff attitude towards communists in the $\mathrm{CIO}$, engendered resistance from more conservative $\mathrm{CIO}$ union leaders, coalescing behind the leadership of Sidney Hillman, president of the Amalgamated Clothing Workers. An ardent supporter of Roosevelt 
and openly anti-Communist, Hillman accused Lewis of harboring communists in the labor movement and called for the expulsion of communist and left-led unions and their supporters, including the SCMWA and UOPWA. Lewis, fearful that Hillman was in alliance with Roosevelt to take over the labor movement, rebuffed Hillman's charges and refused to take action against union leaders who were open Communist Party members or suspected of party affiliation. ${ }^{74}$

As the conflict between the Hillman forces and Lewis broke into open warfare in 1939, the announcement of the Nazi-Soviet non-aggression pact further spurred anti-Communist sentiment within the CIO. Much to Lewis' chagrin, the United Auto Workers (UAW), led by Walter Reuther, passed resolutions at its 1940 convention supporting Roosevelt, condemning the totalitarianism of both Germany and the Soviet Union and barring members who were affiliated with subversive organizations from holding offices in the union. ${ }^{75}$ The pro-Roosevelt and antiCommunist stance of the UAW, one of the largest CIO unions, was a direct challenge to Lewis and an ominous portent of his future ability to maintain control of the CIO. As most of the CIO unions, including those led by open members of the Communist Party, announced their support for Roosevelt in the 1940 election campaign, Lewis announced his endorsement of Republican candidate Wendell Wilkie, further eroding his standing within the CIO. At the $1941 \mathrm{CIO}$ convention, Lewis announced his intention to step down, nominating Phillip Murray to replace him. In a frontal assault against Lewis, unions under the leadership of Hillman introduced a resolution to bar Communists and fascists from holding union offices. 
While the resolution was defeated as a result of last minute negotiations by Lewis, the convention passed a compromise resolution condemning fascist and Communist ideology as having "...no place in this great modern labor movement." ${ }^{, 76}$ Fearful of a draft-Lewis movement at the convention, the Hillman forces threw their support behind Murray, who assumed leadership of the CIO, thus temporarily averting antiCommunist purges.

With the outbreak of World War II, attacks on communism in the CIO generally subsided as the unions declared a no-strike pledge for the duration of the war and directed most of their activities to support of the war effort. ${ }^{77}$ Like the other CIO unions, both the SCMWA and UOPWA generally adhered to the no-strike pledge. During the war, the public relief and welfare unions slowly gained membership, although such gains were hampered by frequent layoffs due to dramatic drops in relief rolls and intensive staff turnover within relief agencies as many male workers joined the military. As the unions refrained from their previous militant insistence on improved salaries and benefits for the duration of the war, real wages for public relief workers dramatically declined between 1941 and 1944, not returning to pre-war levels until $1945 .^{78}$

Partially as a result of the declining political militancy of the unions during the war, a muting of anti-Communism, and a shared priority on serving the war effort, rank and file unions and the AASW grew closer during the war years. Unions representing social workers worked closely with the AASW during the war on war fund drives, community chest fund-raising, and preparations for social welfare 
programming in the post-war period. As relations between the rank and file unions and the professional organization warmed, the $\mathrm{CIO}$ sponsored a series of formal meetings in 1945 between their social work unions and the AASW to chart out common cooperation, culminating in the formation of a joint AASW-CIO Civil Service Association Information Exchange. ${ }^{79}$ Relationships between the unions and the AASW would continue to strengthen in the immediate post-war period, such that in 1946, the AASW, while not fully endorsing social workers' engagement in collective bargaining, included a set of principles regarding collective bargaining and approval of the right of social workers to join unions in its policies on personnel practices. While the mainstream of the profession now recognized trade union membership as not necessarily being in conflict with professional identity, the AASW continued to view labor activities as a primarily non-social work function. ${ }^{80}$ With the end of World War II, the SCMWA, UOPWA, and other CIO unions quickly returned to their more militant tactics of the pre-war period as they sought to rebuild their membership and restore salary levels and benefits that had either stagnated or fallen during the war. In the wake of the war's end, a wave of strikes swept the nation throughout 1945 and 1946 as employers and unions battled over union demands for increased benefits and wages and employer attempts to maintain the lower benefit levels they had enjoyed during the war. ${ }^{81}$ Like other CIO unions, the SCMWA and UOPWA aggressively sought increased benefits for its members and pursued contracts for collective bargaining with additional public and private social welfare agencies. In 1946, the SCWMA merged with the CIO's United 
Federal Workers of America, a union of federal employees, to form the United Public Workers of America (UPWA). As SCMWA president Abram Flaxer assumed leadership of the UPWA, the new union now consisted of between 60,000 and 70,000 members, including an estimated $8,000-10,000$ public relief workers. ${ }^{82}$ The newly-formed UPWA engaged in walk-outs and strikes in numerous cities, most notably New York, Los Angeles, Pittsburgh and Philadelphia, as part of highly successful efforts to win improved wages and benefits for its members. ${ }^{83}$ Also seeking to improve their position, the UOPWA accepted into its union the Federation of Architects, Engineers, Chemists and Teachers, increasing its membership to over 45,000 under its new president, James Durkin. While social work membership remained relatively small in the UOPWA, perhaps 5-6,000 total members in 30 locals nationwide, SSEU locals also joined in the CIO strike wave in New York, Chicago and Los Angeles and were largely successful in regaining benefits lost during the war. ${ }^{84}$

Unions representing rank and file social workers emerged from World War II with a growing membership and a renewed association with the mainstream of the profession. Successful campaigns to revive stagnating membership during the war and new collective bargaining contracts in public and private agencies had been won during 1945 and 1946. And while the demise of Social Work Today had deprived the movement of a central voice, the progressive politics espoused in its pages continued to be voiced in union newsletters and the joint councils of social work 
unions that had formed prior to and during the war. As one social work trade union leader of the time recalled,

Most of us [social workers in unions] were giddy at the end of the war. Giddy about peace and giddy about the future of the union. We had survived the red-hunters before the war and had overcome people like [John] Fitch and his reactionary group of social workers. The question of communism was irrelevant to us for the most part. Sure, many like [Abram] Flaxer, [Elizabeth] Nelson and [James] Durkin were members of the party, but that wasn't an issue. They served the interests of the rank and file, not the party. It was the cold warriors who puffed up the communist stuff, they destroyed our unions, not the communists. ${ }^{85}$

Despite the successes of the unions representing social workers in the immediate post-war period, a rising tide of anti-Communist sentiment in Congress and the nation as a whole, would revive itself in the new era of the Cold War. Finding its origins in the Truman Doctrine of 1947, in which President Truman announced that American foreign policy would challenge Communist aggression wherever it was deemed to threaten freedom and democracy, the politics of the Cold War would come to dominate both foreign and domestic policy during the late 1940s and $1950 \mathrm{~s} .{ }^{86}$ As the perceived threat of communist aggression outside the borders of the United States was converted into an equal fear of internal communist subversion, once again the specter of communist subversion would envelop the unions in a ruthless witch hunt from both within and outside of the labor movement.

Within the CIO, the revival of anticommunist forces signaled the beginning of a bitter struggle within the leadership of the CIO over the communist question. Struggles between anticommunist and communist and left-led groupings wracked the 
United Automobile Workers, the United Electrical Workers, and the National Maritime Union. In October of 1946, 34 CIO unions formed the CIO Committee for Renovative Trade Unions, with the expressed purpose of ousting what they considered communist-controlled unions. ${ }^{87}$ At the CIO's 1946 national convention unions in the committee put forth a resolution calling on the CIO to reject policies "...emanating from totalitarianism, dictatorships and foreign ideologies such as Communism and Fascism." ${ }^{\text {88 }}$ CIO president Phil Murray, seeking to avoid a fatal split in the union, appointed a six-person committee to draft a compromise resolution. Included on the committee were Abram Flaxer of the UPWA, Mike Quill, the open Communist leader of the Transport Workers Union, and Ben Gold, president of the Fur and Leather Workers of America, also an open member of the Communist Party. Faced with pressure by Murray to adopt a compromise that would avoid expulsions, Flaxer and the others on the committee reluctantly adopted an alternative resolution subsequently passed by the convention stating that convention delegates "....resent and reject efforts of the Communist Party or other political parties and their adherents to interfere in the affairs of the CIO." ${ }^{, 89}$ But the hopes of Flaxer and other union leaders accused of heading communist-dominated unions that the compromise resolution would avoid purges were quickly dashed. Following the national convention, local and state CIO conventions in New York, Michigan, Los Angeles, Washington and other areas adopted similar anticommunist resolutions, ousting suspected communists from leadership positions in the state and local union joint councils. ${ }^{90}$ Seeking to avoid internal dissension, UOPWA president Lewis 
Merrill ordered his union members and officers to avoid identification with the Communist Party, threatening disciplinary action against those who failed to do so. Following his announcement, Merrill resigned from his position as a contributing editor to the New Masses magazine as well as resigning from the board of directors of the Jefferson School, long associated with the Communist Party. ${ }^{91}$ Despite Merrill's attempts to distance the union from charges of communism, the UOPWA, as well as the UPWA, battled attempts of other anti-Communist CIO unions to raid their membership, as well as raids by the AFL's American Federation of Government Employees. ${ }^{92}$

Beset by internal conflict within the CIO, the unions representing social workers faced new threats from the Truman Administration and a Republicancontrolled Congress. In March of 1947, President Truman issued an executive order establishing a federal loyalty oath program, requiring all federal employees to sign an oath that they did not belong to any subversive organizations as identified by the U.S. Attorney General. Coming on the heels of the UPWA's resistance to signing the Hatch Act of 1939, which prohibited public employees from engaging in political activities, the loyalty oath program would decimate union membership. The unions' refusal to sign provisions of the Hatch Act had already denied them federal protections of the right to collective bargaining, and they had struggled to maintain recognition by employers throughout the early 1940s. Following affirmation of the Hatch Act by the Supreme Court in a challenge brought by the UPWA, UOPWA and UPWA unions had only recently agreed to its provisions as the loyalty program was 
created. ${ }^{93}$ Now, as the UPWA's leaders and members refused to sign loyalty oaths, or found themselves under investigation for suspected disloyalty, a wave of dismissals and resignations increasingly crippled the union's ability to represent federal workers. By the end of 1947, the impact of the loyalty program, coupled with raids by the AFL, found the UPWA considering the advantages of forming a separate union of federal employees outside of the UPWA. ${ }^{94}$ Compounding the difficulties of the UPWA and the UOPWA, the Republican-controlled Congress overrode President Truman's veto of the Taft-Hartley Act in 1947, requiring all union officers to sign an oath specifically denying membership in or affiliation with the Communist Party and banning strikes by federal employees. ${ }^{95}$ Once again, UPWA leaders refused to comply, were stripped of representation protection by the National Labor Relations Board, and found many companies and social agencies now refusing to recognize the union's right to represent employees and voiding contracts. ${ }^{96}$

The social work unions of the UPWA came under particular attack in New York. Following passage of the federal Taft-Hartley Act, the New York state legislature passed legislation forbidding public employees from going on strike. Adding to the anti-union legislation, newspapers in New York City had attacked the UPWA for alleged communism and blamed its permissive policies for encouraging a rise in relief rolls in the city during 1946 and 1947. As newspapers published attacks on the morals and lack of work incentives among recipients, the UPWA responded with the distribution of thousands of leaflets describing the facts of poverty in the 
city and sponsored demonstrations of support for maintaining and expanding relief benefits. While the union struggled with the city's Welfare Department to win a new contract, a rival organization, the Civil Service Forum, organized to condemn the leadership of the UPWA and woo away UPWA members disturbed by charges of communist control of the union. ${ }^{97}$

Besieged within the $\mathrm{CIO}$, and under attack by federal investigators, the unions representing social workers received their final blow during the 1948 and 1949 national conventions of the CIO. As delegates to the 1948 CIO national convention gathered in Portland, Oregon, anti-Communist forces within the $\mathrm{CIO}$, now under the leadership Walter Reuther, held sufficient power to call for the expulsion of the left-led unions. Challenging CIO president Phil Murray, who had been reluctant to act upon the anti-Communist resolutions of previous conventions, Reuther warned, "You [Murray] are not going to be tolerated forever in this program of deliberate planned madness of destroying the American labor movement and sabotaging the basic policies of the CIO." ${ }^{.98}$ Following Reuther's challenge, Murray now moved to the right, acknowledging communist domination of some unions. Murray now authorized the CIO's Executive Board to investigate unions suspected not specifically of communist influence but of misuse of union funds and negligence in carrying out union responsibilities. In authorizing the investigations, Murray cited the UOPWA as an example of such negligence, complaining the union had wasted funds and the time of the CIO Executive Board with complaints of raiding by other CIO unions. ${ }^{99}$ 
By the time of the 1949 ClO national convention in Cleveland, unions accused of communist-domination such as the UOPWA and the UPWA were struggling for survival in the face of rapidly declining membership as a result of state and federal anti-Communist investigations and internal raids by $\mathrm{CIO}$ and $\mathrm{AFL}$ rival unions. Now isolated within the labor movement, the unions were helpless to prevent their impending expulsions from the CIO. Delegates to the convention now passed resolutions barring members of the Communist Party from membership on the CIO's Executive Board and authorized the Executive Board to expel any affiliate union deemed by the Board to be acting in support of the program of the Communist Party. The Convention then expelled the United Electrical and Radio Workers of America, which had boycotted the convention, and the Farm Equipment Workers Union on charges of Communist domination. Following the expulsion, UOPWA president James Durkin proclaimed, "I don't know what the hell will happen next," and the UOPWA director of organization characterized the situation as "a bloody mess." 100

The answer to Durkin's lament came the day after the 1949 convention closed. The CIO Executive Board ordered expulsion hearings on the UOPWA, the UPWA, and eight other unions accused of Communist-domination. Beginning hearings in January, 1950, the Executive Board acted quickly, expelling all ten unions on February $15,1950 .{ }^{101}$ In the final reports of the expulsions, the Executive Board determined that the UOPWA “...followed and continue to follow exactly, without deviation, the program of the Communist Party...Never in the history of the 
UOPWA has any policy ever been adopted which in any way runs counter to the policies of the Communist Party or to the interests of the Soviet Union..."102 In a similar fashion, the Executive Board concluded that the UPWA had also followed the Communist Party line in the post-war period. Cognizant that the UPWA primarily consisted of federal employees, the Board took pains to note in its report that it “...wishes to make crystal clear that its condemnation of that [UPWA] leadership, and of the union, does not necessarily reflect a condemnation of each individual member...the jobs of many of whose members would be endangered by a fallacious translation of the Committee's findings as to the union leadership into a condemnation of each of its individual members., ${ }^{103}$ In its efforts to separate the loyalty of the UPWA's general membership from its leaders, the report specifically focused on the alleged Communist Party affiliation of UPWA President Abram Flaxer and the union's secretary-treasurer, Eleanor Nelson. ${ }^{104}$

Expelled by the CIO, the UOPWA and the UPWA were now a mere semblance of their former selves. UOPWA membership, estimated in 1946 to be nearly 45,000 , had dropped to only 12,000 by the time of their expulsion. The UPWA suffered similar devastating losses in membership, shrinking from a peak of nearly 80,000 members in 1947 to less than 2,500 by $1952 .{ }^{105}$ Stripped of CIO affiliation for alleged communist-domination, the unions were now attacked with fury by state and local anti-Communist and subversive activities committees. Purges of union members in public relief and welfare agencies occurred throughout the country in rapid succession during 1949 and 1950, including Detroit, Los Angeles, 
New York City, Chicago, Pittsburgh, Cleveland, and Washington State. ${ }^{106}$ In Detroit, the city's mayor accused the UPWA locals of harboring some 150 members of the Communist Party, and the city's Loyalty Commission launched a probe into city employee loyalty. ${ }^{107}$ In Los Angeles, county and city loyalty oath requirements were used to investigate and purge UPWA members from public relief agencies and other city and county agencies. ${ }^{108}$ In New York City, where the now remaining 1,500 members of the UPWA made it the largest of the national union's locals representing social workers, a particularly bitter assault upon the union was unleashed by the city's Department of Welfare. Between 1947 and 1950, successive commissioners of the Department of Welfare attacked the UPWA as being dominated by communists. In 1949, Welfare Department commissioner Raymond Hilliard announced his determination to "...chase the Communists out of the Department" and began a concerted campaign to break the union's hold over department collective bargaining agreements. ${ }^{109}$ Using such tactics as photographing union members seen participating in demonstrations or protests over relief policies, Hilliard subsequently dismissed union activists on charges of inefficiency and insubordination. Upon the UPWA's expulsion from the CIO, Hilliard refused to recognize the union and continued to purge the department of UPWA members. By March, 1951 nearly 200 UPWA members had been fired by the Department of Welfare. ${ }^{110}$ As the attacks on UPWA continued nationwide, the union finally disbanded in 1953 with a membership of only 2,500 , now replaced by a new union in the CIO, the Government and Civic Employees Organizing Committee. ${ }^{111}$ 
SSEU locals in the UOPWA did not fare any better than those in the UPWA. SSEU membership, now concentrated in the Jewish social service agencies of New York and Los Angeles, were also challenged by rival unions, and most agencies refused to recognize SSEU bargaining rights or representation of employees. ${ }^{112}$ In a desperate attempt to maintain their membership, the UOPWA joined with three other unions expelled by the CIO to merge with the left-led and independent Distributive Workers Union, now renamed the Distributive, Processing and Office Workers Union of America (DPOWA). In the resulting merger, former UOPWA president James Durkin was named DPOWA secretary-treasurer. Claiming a membership of less than 8,000 at its founding convention, the DPOWA absorbed the few remaining members of the New York and Los Angeles SSEU locals, now numbering only hundreds. ${ }^{113}$ Attacked by other unions and public officials as a communistdominated union, the DPOWA subsequently purged their leadership in 1953, expelling the last of the mostly Communist Party member social workers still in the union. $^{114}$ 


\section{Notes to Chapter 6}

1. Characterization of the State, County and Municipal Workers of America in 1940 by Samuel Yorty, quoted in: California Strategy Committee, SCMWA, "Professional values and county jails," SWT (June-July 1940), p. 15. Yorty was chair of the California Legislative Committee investigating subversive influence in state relief agencies.

2. Olson, Unfinished business, pp. 35-36; Fisher, The response of social work to the Depression, pp. 201-202.

3. "Draft convention resolutions," The Communist (April 1938), p. 355.

4. Interview by author with Abram Flaxer, August 16, 1980; "The month," $S W T$ (May 1938), p. 25.

5. "The month," SWT (November 1937), p. 25.

6. Winifred Chappell, "Social workers and war," SWT (November 1937), p. 12.

7. Ibid.

8. "Peace and democracy: Agenda," SWT(April 1938), p. 4.

9. Ibid.

10. “A positive peace policy,” $S W T$ (May 1939), p. 25.

11. Paul Kellogg, "Between going to war - And doing nothing," Survey Graphic (March 1939, p. 228; Paul Kellogg Papers, SWHA, Box 36; John Gavit, "Through neighbors doorways," Survey Graphic (December, 1938), p. 611. See also Olson, Unfinished business, pp. 35-40.

12. “Social work's answer," SWT(January 1939), p. 23.

13. Solomon Lowenstein, "The test of American democracy," Proceedings of the National Conference on Social Work, 1938 (Chicago: University of Chicago Press, 1938), p. 20.

14. Interviews by author with Abram Flaxer, August 16, 1980, and Jacob Fisher, March 30, 1980; Olson, Unfinished business, pp. 39-40; Fisher, The response of social work to the Depression, pp. 202-2-3. 
15. Peggy Dennis, The autobiography of an American communist (Berkeley: Lawrence Hill, 1977), p. 110-111; Klehr, The heyday of American communism, p. 219; Foster, History of the Communist Party, pp. 371-373.

16. U.S. Congress. Senate. Senate Committee on Government Operations, Congressional investigations of Communists and subversive activities Summary index 1918-1956. $84^{\text {th }}$ Congress (December, 1957).

17. "An appeal for Spain," $S W T$ (April 1937), p. 4; "Medical aid to Spain," SWT (May 1937), p. 29.

18. "Case record of new Spain," $S W T$ (November 1937), pp. 9-11; "Case record of new Spain," $S W T$ (December 1937), pp. 21-22; Constance Kyle and Jen Chakin, "Spain's call and our answer," $S W T$ (April 1938), pp. 13-14; Paul Kellogg Papers, SWHA, Box 1.

Interestingly, Bertha Reynolds credits Kyle, a former student of hers, with temporarily breaking the blacklist that had stalled her career. According to Reynolds, it was Kyle who helped her obtain a position with the National Maritime Union in 1943 (Reynolds, An uncharted journey, p. 242).

19. SWT (June 1937), p. 26.

20. No accurate figures are possible to obtain, as serving in Spain was illegal under U.S. law and transport to and service in Spain was highly secretive. Herbert Aptheker recalls that at least a half dozen social workers fought in the Abraham Lincoln Brigade (interview with author, July 28, 1980). Abram Flaxer estimates between 15 and 20 social workers volunteered (interview by author, August 16, 1980).

21. Throughout the early months of 1939 , numerous SSEU locals of UOPWA and SCMWA unions representing rank and file social workers passed resolutions calling on U.S. abandonment of a policy of neutrality. For example, see: "Trade union notes," SWT (January 1939), p. 25; "Trade union notes," SWT (March 1939), p. 25; and "Trade union notes," SWT (May 1939), p. 27.

22. "The month," SWT (April 1939), p. 22.

23. The Daily Worker (July 6, 1939), p. 4.

24. "Keep America out of the imperialist war," The Daily Worker (September 19, 1939), p. 1. 
25. Ibid.

26. Dennis, Autobiography of an American communist, p. 139.

27. Caute, The fellow travelers, pp. 200-201; Isserman, Which side were you on?, pp. 37-38; Healey and Isserman, California red, pp. 81-83.

28. "The war and the New Deal," SWT (October 1939), p. 5; interview by author with Abram Flaxer, August 16, 1980; interview by author with Jacob Fisher, September 9, 1980.

29. “The war and the New Deal," SWT(October 1939), p. 5.

30. Ibid.

31. Ibid.

32. "Meeting social need: A peace program," SWT (January 1940), p. 5.

33. Ibid.

34. Ibid.

35. Ibid.

36. Interview by author with Jacob Fisher, March 30, 1980; Gertrude Spring, "Our defense must be from within," Survey (June 1940); Olson, Unfinished business, pp. 41-42.

Indeed, as late as its 1940 delegate convention, the AASW urged continued support of social welfare programs as the best defense against involvement in a foreign war, and the American Association of Social Work Students endorsed Social Work Today's Program for Peace ("AASW and AASWS," SWT (JuneJuly 1940), p. 26.

37. Mary van Kleeck, "Social work in the world crisis," SWT (March 1940), pp. 5-8. Quote from page 8.

38. "Lewis warns political parties about war," SWT (June-July 1940), p. 27.

39. United Office and Professional Workers of America, Proceedings of the Constitutional Convention of the United Office and Professional Workers of America, CIO, Chicago, Illinois (1940); “The month," SWT (June-July 1940), p. 
27; Gwen Barclay, "Welfare, not warfare," SWT (October 1940), p. 11; Henry Doliner, "In answer to war hysteria," SWT (October 1940), p. 12.

40. Doniner, Ibid.; Clara Rabinowitz, "Mr. President, we want peace," SWT (JuneJuly 1940), pp. 7-8.

41. Virginia Malbin, "Grand Rapids comes to the conference," SWT (June-July 1940), pp. 11-14; Fisher, The response of social work to the Depression, p. 208.

42. Frank Bancroft, "Social work and defense," SWT (October 1940), p. 7.

43. Ibid., p. 10.

44. “AASW and social defense," SWT (November 1940), p. 26.

45. "The people's program in 1941," $S W T$ (May 1941), p. 3, 7.

46. Isserman, Which side were you on?, p.p. 104-110.

47. Albert Deutsch, "Let's face facts this time," SWT (November 1941), pp. 3-6.

48. “SCMWA convention,” SWT (November 1941), p. 27.

49. "Social work in the nation's service," SWT (January 1942), pp. 3-4.

50. Constance Kyle, "In the war to win," SWT (February 1942), pp. 29-31; Gus Jacobson, "Defeat fascism," SWT (February 1942), pp. 32-34; Fisher, The response of social work to the Depression, p. 220.

51. Bertha Reynolds, "There will be new heights of devotion," SWT (February 1942, p. 50 .

Reynolds would later recall that with the demise of Social Work Today, ".... a light went out in social work which has never been re-kindled" (Reynolds, $A n$ uncharted journey, p. 240).

52. "Social Work Today," Harry Lurie Papers, SWHA, Box 1, Folder 13. While the mimeograph tract was unsigned, Jacob Fisher confirmed in an interview with the author that the committee under the leadership of John Fitch authored both the paper and the second memorandum distributed in June of 1941 (February 12, 1981). 
53. "Social Work Today," Harry Lurie Papers, SWHA, Box 1, Folder 13.

54. "Social Work Today. Supplement to Memorandum of October, 1940," Harry Lurie Papers, SWHA, Box 1, Folder 13.

55. Fisher, The response of social work to the Depression, p. 218.

56. Isserman, Which side were you on?, pp. 36-37.

57. Ibid., pp. 44-45; Caute, The fellow travelers, p. 201.

58. Archibald MacLeish, "Liberalism and the anti-fascist front," Survey Graphic (May 1939), pp. 321-323.

59. Letter from Harry Lurie to Frank Bancroft, September 14, 1941. Harry Lurie Papers, SWHA, Box 1, Folder 13.

60. Lamont, The trial of Elizabeth Gurley Brown by the American Civil Liberties Union.

61. For example, see: Gellhorn, The states and subversion; Caute, The great fear; and Carr, The House Un-American Activities Committee.

62. Isserman, Which side were you on?, pp. 67-68.

63. Quote from Ibid., p. 68. See also: Schrecker, Many are the crimes, pp. 97-98; and Carr, The House Un-American Activities Committee.

64. Gellhorn, The states and subversion; Walter Goodman, The committee: the extraordinary career of the House Un-American Activities Committee (New York: Farrar, Straus and Giroux, 1968).

65. Carr, The House Committee on Un-American Activities, pp. 17-18.

66. Gellhorn, The states and subversion, pp. 2-6; Barrett, The Tenney Committee, pp. 1-10.

67. Gellhorn, Ibid.; Barrett, Ibid.; California Strategy Committee, SCMWA, CIO, “Professional values and county jails," SWT (June-July 1930), p. 15, 30.

68. Max Bogner papers, SWHA, Box 1; Paul Jacobs, Is Curly Jewish? (New York: Antheum, 1965), pp. 166-168; personal communication from Max Bogner, 
August 12, 1980; interview by author with Bronislaus Zukas, June 14, 1980.

69. "Philadelphia witch hunt," SWT (February 1942), p. 29; McCulloch, White collar workers in transition, p. 26.

70. Ibid.; U.S. Congress. House of Representatives. Committee on Un-American Activities, Investigation of communist activities in the Philadelphia area. Hearings. Parts 1-4. $83^{\text {rd }}$ Congress, $1^{\text {st }}$ and $2^{\text {nd }}$ Sessions (1953-54).

71. Interview by author with Abram Flaxer, August 16, 1980.

72. Ibid.; Gellhorn, The states and subversion; Caute, The great fear.

73. Levenstein, Communism, anticommunism and the CIO, pp. 36-70.

74. Ibid.; pp. 90-93; Zieger, The CIO, pp. 100-110.

75. Zieger, Ibid.; Isserman, Which side were you on?, pp. 74-82.

76. Isserman, Ibid., P. 75.

77. Levenstein, Communism, anticommunism and the CIO, pp. 140-152.

78. McCulloch, White collar workers in transition, pp. 41-42.

79. "White collar aid is offered by CIO," New York Times (January 16, 1945), p. 36.

80. Personal communication from Chauncey Alexander, August 26, 1980.

81. Preis, Labor's giant step, pp. 257-286.

82. McCulloch, White collar workers in transition, p. 52. F. O'Brien, "The 'Communist-dominated' unions in the United States since 1950," Labor History 9(2), pp. 184-209. Social work estimate from interview by author with Abram Flaxer, August 16, 1980.

83. McCulloch, Ibid., pp. 52-53; Jacobs, Is Curly Jewish?, pp. 149-150.

84. Interview by author with Abram Flaxer, August 16, 1980; O'Brien, "The 'Communist-dominated' unions in the United States since 1950," LH, pp. 184209; Alexander, Organizing the professional social worker, p. 200. 
85. Interview by author with "Sarah," February 2, 1982. Elizabeth Nelson was the secretary-treasurer of the United Federal Workers of America (CIO), accused by HUAC of being a communist (U.S. Congress. House of Representatives. Committee on Un-American Activities, Investigation of Un-American activities and propaganda. U.S. Congress, $2^{\text {nd }}$ Session (March 29, 1944).

"Sarah" requested anonymity in her interview. A rank and file activist and union official in the mid-west, Sarah was one of a handful of social workers sentenced to prison for her refusal to cooperate with anti-Communist investigations in the 1950s. Despite receiving support from some of her former colleagues, Sarah recalled that she was abandoned and shunned by most in the profession. Following her release from prison, Sarah left the field and later retired in Seattle, Washington.

86. Caute, The great fear; Ann Ginger and David Christiano (Eds.), The cold war against labor (Berkeley, CA: Meiklejohn Civil Liberties Institute, 1987).

87. Levenstein, Communism, anticommunism and the CIO, pp. 212-213.

88. Ibid., p. 213.

89. Ibid., p. 213-214; see also Kampelman, The Communist Party vs. the C.I.O., pp. 45-60.

90. Levenstein, Ibid., p 215; Kampelman, Ibid., pp. 63-65.

91. Ibid.

92. Ginger and Christiano, The cold war against labor, pp. 386-386; Levenstein, Communism, anticommunism and the CIO, p. 277.

93. J. Prickett, Communists and the communist issue in the American labor movement, 1920-1950 (Unpublished doctoral dissertation, University of California, 1975); W. J. Steelfeldt, United Public Workers of America v. Harry B. Mitchell: The doctrine of political neutrality (Unpublished doctoral dissertation, University of Chicago, 1951); United Office and Professional Workers of America, Proceedings of the Constitutional Convention of the United Office and Professional Workers of America, CIO, Chicago, Illinois (1940).

94. Congress of Industrial Organizations, Proceedings of the $11^{\text {th }}$ Constitutional Convention of the Congress of Industrial Organizations, Cleveland, Ohio (1949). 
95. Ellen Bontecou, The federal loyalty-security program (Ithaca, NY: Cornell University Press, 1953).

96. Levenstein, Communism, anticommunism and the CIO, pp. 276-277; Ginger and Christiano, The cold war against labor, p. 387; interview by author with Abram Flaxer, August 16, 1980.

97. "Relief funds being spent without proper controls," New York Times (May 25, 1947), p. 1; "N.Y. press launches attack on welfare," Public Record (June 1947), p. 6; McCulloch, White collar workers in transition, pp. 74-75; interview by author with Clara Rabinowitz, November 24, 1980.

98. Congress of Industrial Organizations, Proceedings of the $11^{\text {th }}$ Constitutional Convention of the Congress of Industrial Organizations, Cleveland, Ohio (1949), pp. 170-171.

99. Ibid., pp. 342-343.

100. Kampelman, The Communist Party vs. the C.I.O., pp. 157-164; Levenstein, Communism, anticommunism and the CIO, pp. 288-307; Zieger, The CIO, pp. 289-293. Quotes as cited in Levenstein, p. 302.

101. Kampelman, Ibid., p. 162; David Saposs, Communism in American unions (New York: McGraw Hill, 1959).

102. Kampelman, Ibid., p. 167.

103. Ibid., p. 171.

104. Ibid., p. 172.

105. Ibid., p. 167; O'Brien, 'The 'Communist-dominated' unions in the United States since 1950," LH, pp. 184-209.

106. Caute, The great fear, pp. 339-345; McCulloch, White collar workers in transition, pp. 74-77; interview by author with Abram Flaxer, August 16, 1980. Interview by author with Margaret Wheeler, September 19, 1979. Wheeler was a UPWA member in Washington State, where investigations of public relief workers were concentrated in Seattle.

107. Caute, Ibid.; State of California. Legislature Assembly. Joint Fact-finding Committee on Un-American Activities, Un-American activities in CaliforniaCumulative Index (Sacramento: California State Printing Office, 1956); U.S. 
Congress. House of Representatives. Committee on Un-American Activities, Guide to subversive organizations and publications (and appendix) ( $84^{\text {th }}$ Congress, $1^{\text {st }}$ Session. March, 1951); U.S. Congress. House of Representatives. Committee on Un-American Activities, Communist Party activities in the professions. Hearings held in San Francisco, California $\left(84^{\text {th }}\right.$ Congress, $1^{\text {st }}$ session, 1957); U. S. Congress. House of Representatives, Investigation of communist activities in the New York City area - Part $1\left(83^{\text {rd }}\right.$ Congress, $1^{\text {st }}$ session, 1953); U.S. Congress. House of Representatives. Committee on UnAmerican Activities, Investigation of communist activities in the Seattle, Wa. area-Part $2\left(84^{\text {th }}\right.$ Congress, $1^{\text {st }}$ session, 1957).

108. Ibid.; personal communication with author by Max Bogner, August 12, 1980. Bogner was a member of an SSEU local and named as a member of the union's "Communist group" by witnesses testifying before the state's Tenney Committee.

109. Quoted in Caute, Ibid., p. 343; U. S. Congress. House of Representatives. Committee on Un-American Activities, Investigation of communist activities in the California area - Part $5\left(83^{\text {rd }}\right.$ Congress, $1^{\text {st }}$ session. 1953)

110. Caute, Ibid., pp. 343-344; McCulloch, White collar workers in transition, pp. 74-77; interview by author with Julia Barnes, July 5, 1980.

111. Levenstein, Communism, anticommunism and the CIO, p. 325; U.S. Congress. Senate. Subcommittee on Internal Security of the Committee on the Judiciary, Subversive control of the United Public Workers of America. Hearings (82d Congress, $1^{\text {st }}$ Session, 1952).

112. Alexander, Organizing the professional social worker, p. 201; personal communication with author by Max Bogner, August 12, 1980.

113. Distributive, Processing and Office Workers of America, Proceedings of the Founding Convention: Distributive, Processing and Office Workers of America, New York City, New York (1950).

114. Union Voice 9(8) (April 19, 1953), p. 1. Union Voice was the official newsletter of the DPOWA; interview by author with "Max," February 17, 1990. Max talked to the author on conditions on anonymity. A social work member of the DPOWA, Max confirmed that the SSEU social workers who joined the DPOWA were the "...hard-core members of the party," hoping the DPOWA would provide a refuge for their politics. See also: U.S. Congress. Senate. Subcommittee on Internal Security of the Committee on the Judiciary, Subversive control of the Distributive, Processing and Office Workers of 
America. Hearings. (82d Congress, $1^{\text {st }}$ and $2^{\text {nd }}$ Session, 1952). 


\section{CHAPTER 7:}

\section{CONCLUSIONS}

In the long run I think we represented what social work professed and also feared, social workers who weren't afraid to stand up for the people, the unemployed and the exploited. The rank and file was a lesson to social work that doing that was dangerous. People lost their jobs, we were called Communists and sometimes hauled off to jail. It scared them and I think they really gave up on it after that in a very basic way. I'm not saying that we were the golden age or anything like that, but look at what we've got now. That's the saddest thing. Not what happened to me and others, but what happened to social work. ${ }^{1}$

("Sarah,"1982)

The expulsions of the UOPWA and the UPWA from the CIO marked the final demise of the rank and file movement in social work. During the turbulent years between 1946 and the unions' expulsions from the CIO in 1950, it also marked a drawing back of the AASW from its brief flirtations with the unions during World War II. As charges of communist domination enveloped the unions representing social workers, the mainstream of the profession withdrew its associations with the rank and file unions. In the JCTU's final appearance at the 1950 NCSW, JCTU sessions drew few numbers and were challenged by a new organization, the Community and Social Agency Employees, which had replaced the SSEU in most of New York City's private Jewish social serve agencies. ${ }^{2}$ Following the CIO expulsions of the UOPWA and UPWA, the Executive Committee of the NCSW now refused to recognize the JCTU, citing the union expulsions and denying the JCTU a presence at the 1951 NCSW. ${ }^{3}$ As purges of public relief workers occurred throughout the country, and federal and state subversive activities committees 
questioned the loyalty of social work trade unionists, the response of the AASW was intensely circumspect. In a special issue on civil rights published in 1948 by the AASW's official publication, Social Work Journal, the politically cautious nature of the profession was clearly expressed:

While this issue of the Social Work Journal has been in preparation the House Un-American Activities Committee has been investigating Communist infiltration into key governmental positions. There is undeniable evidence that such infiltration has occurred. There is undeniable evidence, also, that communist political philosophy and practice are irreconcilable with democratic constitutional government. ${ }^{4}$

While the AASW would express concerns over the tactics of the HUAC and loyalty oath programs, its 1949 policy statement on civil rights restricted AASW activities or public statements in defense of civil rights violations to only members of the organization. $^{5}$ By 1951, the AASW's willingness to even oppose cuts in social welfare services was also almost non-existent as it refrained from comment on the firing of New Deal social worker Jane Hoey from the federal department of Health, Education and Welfare by the Eisenhower administration. Fired after protesting proposed cuts in federal social welfare programs, Hoey sought the assistance of the AASW. The AASW chose to demur, stating the AASW could not take action on any situation that involved "... a particular person." The AASW became even more silent in its consideration of the merits of social workers' involvement in the labor movement. Following the expulsions of the rank and file unions, the few articles that addressed social work participation in the labor movement published in Social Work Journal would question the ethical conflicts that arose between a profession 
and participation in trade union activities. Typical of such sentiments, one article in 1948 stated, “Unionism's endeavor to organize professional personnel by appeals to worker solidarity, when professionals regard themselves as a group set above the common herd, has been a tactic as self-defeating as it has been persistent." Indeed, the profession's turn from involvement in labor organizations was such that by 1954 , the Social Work Yearbook would have only this to say: "The union movement in social work, which arose from the conditions of the depression of the 1930s, has been limited in extent and influence and is apparently confined to a few metropolitan areas."

The profession's relative silence during the anti-Communist hysteria of the late 1940s and the 1950s was of little comfort to its victims. As the internal cold war of the 1950s continued to investigate organizations and individuals considered subversive, many social workers who were prominent in the rank and file movement faced blacklists, subpoenas, and even jail. Some rank and file activists, such as Bertha Reynolds, Bronislaus Zukas, Max Bogner, and others all suffered from informal blacklists that followed them for years. Others would lose their jobs as their previous association with the rank and file movement and the progressive causes it espoused became the subject of loyalty investigations. Jacob Fisher, one time editor of Social Work Today and early rank and file union leader, was suspended from his job in the Social Security Administration in 1954 after being labeled a "security risk." Unable to find a job in social work after his suspension, Fisher joined the staff of a consulting firm until his retirement. With the exception 
of Bertha Reynolds and a few other social workers, Fisher recalls that he was ignored in his plight by the mainstream profession..$^{10}$ Meyer Schreiber, a member of several organizations deemed subversive by the government, was labeled a "national security risk" following an investigation by the Federal Bureau of Investigation (FBI) of his background while an employee of the U.S. Children's Bureau in 1964. Schreiber recalls that the profession participated in providing information on him to the FBI:

An inquiry [by the FBI] was made of the Columbia University School of Social Work, where I had graduated in February 1949. I was amazed at the ease with which information was given about me. In 1991, I wrote three letters to the school's dean and asked about the school's policy of giving out information to any source about graduates; no reply was received. Similarly I wrote to the Council on Social Work Education and did not receive a reply...The National Association of Social Workers was part of the investigation. A special FBI unit investigated the Chicago chapter and combed the chapter's records to learn if I had been involved in whatever the FBI defined as subversive activities in Chicago. ${ }^{11}$

Margaret Wheeler, who lost her job as a social worker in Washington after being called before the HUAC in its investigation of the UPWA and refusing to answer committee questions, remembers:

The professional association shunned me when I was going through the HUAC persecution. They refused to come to my side or even offer advice. They wanted to stay as far away from communists as possible. They didn't know if I was a communist or not. All they cared about was that the committee said I was. Most of them were cowards, nearly all of them. ${ }^{12}$

Abram Flaxer, former president of the UPWA, was cited for contempt by the U.S. Congress after his refusal to answer questions of his affiliation with the Communist 
Party before the U.S. Senate Sub-Committee on Internal Security. Subsequently tried and convicted, Flaxer's conviction was eventually overturned by the Supreme Court in $1958 .{ }^{13}$ Flaxer recalls, "I was an absolute anathema to the leaders in social work. They would have never dreamed of saying anything in my defense. I didn't expect them to and they sure never did." 14

The legacy that the rank and file movement has left for the profession of social work is, as can be expected, a mixed one. Perhaps like no other rebellion within the history of the profession's ranks, the movement best exemplifies the dualistic conflicts that have divided the profession since its inception. The historic tensions within the profession over the nature of its professional identity versus its relationship to labor unions and other forms of organization, and its debates over the merits of social reform versus the advisability of a technique-based practice, are well informed by a study of the rank and file movement. For members of the rank and file movement, affiliation and identity with organized labor and the social and political causes promoted by the union movement were not seen as an inherent conflict with their identity as social workers. Rather, many saw a clear identification with the workers movement, merged with the skills and specialized knowledge of the profession, as essential to the development of a truly democratic occupation fully imbued with the values of social and economic justice. The debates of today within the profession over the balance between social reform activity and the performance of direct clinical services have almost studiously avoided the synthesis of these two as attempted by the rank and file. It is, perhaps, because of this avoidance that the 
debate within the profession over its proper role and function so often has reduced itself to tired dogmas devoid of any possible meaningful dialogue.

The unions of the rank and file movement also demonstrated to many social workers that participation in trade unions was of immediate and long-lasting benefit. Rank and file unions were the first to establish standards of working conditions, salaries, and benefits in public and private agencies that were guaranteed through collective bargaining contracts. While the original unions created by social workers were destroyed in the hysteria of McCarthyism and the Cold War, their impact on both the private and public sector have continued today, although considerably muted in terms of political content or social work identity. During the 1980 s and 1990s, while overall union membership has declined in the United States, it has grown within the public sector. ${ }^{15}$ As of 1993 , nearly 25 percent of the over 400,000 social workers in the labor force were members of unions, mostly concentrated in the public sector in the AFL-CIO's Service Employees International Union (SEIU) and the American Federation of State, County, and Municipal Employees. ${ }^{16}$ These unions have been highly successful in efforts to maintain or increase member salaries and benefits and have contributed to public agency improvement of standards of services to their clients. Equally important, as Milton Tambor points out, progressive social work ideas and organizations have been sustained largely within the context of the trade union movement. ${ }^{17}$ Whether in the actual workings of the unions or in the identification of the union movement and its historic concerns with the needs of poor and working people as expressed in the pages of progressive social 
work journals such as the Journal of Sociology and Social Welfare and the Journal of Progressive Human Services, the labor movement continues to represent social works' most outward expressions and forms of struggle for social and economic justice.

At the same time as the movement historically points out for our profession directions for progressive political action, the experiences of the movement have also served to mitigate against such progressive perspectives and actions. Lessons regarding the limits of social reform, and the power of the state to contain and even destroy such efforts, were not lost on the profession as the rank and file unions were destroyed. As the political repression of McCarthyism and the Cold War targeted social work unions, the profession stood largely aside, content to consolidate its professional organization and reorient its ranks to the relative safety of technique, bureaucracy, and political moderation. While temporarily shaken from its professional complacency by the radical social work movement of the late 1960 s and early 1970s, the profession today continues to be wary of asking too much or going too far for its clients. Indeed, the politics of fear as engendered in the times of the rank and file movement, are powerful modifiers of both individual and organizational behavior. It is perhaps too easy for the profession to lose sight of the positive lessons and victories of the rank and file movement, for the lessons of failure have been extreme. It has also been perhaps too easy for the profession to forget the contributions of those social workers who most suffered from their willingness to struggle for the rights of poor, unemployed and working people. Few 
of those who were victims of blacklists and congressional inquisitions are remembered today, and fewer still are honored for their courage and struggle.

In these senses, a fuller explication of the history of the rank and file movement, its meaning within the historical context of the profession's development and the insights that the movement provides regarding the optimum form and function of the profession remain largely unexplored. In this regard, further examination of the movement's attempts to integrate social work practice theory and technique with politically liberatory theory and its practice is called for. In addition, further study into the actual internal workings of the social work trade unions is needed. Such study would further explain how the unions successfully reached out to social workers, established strategies and tactics for collective bargaining, and linked themselves with the broader industrial workers movement. Information on the role of women and minorities in the rank and file movement is nearly nonexistent. Given that the unions representing the rank and file held higher proportions of women and minorities than most other $\mathrm{CIO}$ unions of the time, explicating these important histories would help to fill a gap in both social work and labor history. Finally, it is clear that deeper examination of the relationship of the rank and file movement to the Communist Party and the political lines of the party is necessary. This need is particularly salient, as the charges of communist-domination that helped lead to the movement's ultimate destruction have continually and consistently been attributed to the few historical accounts of the movement as the reasons for its downfall and questionable relevance to the field today. In this regard, the tendency 
of these accounts has been to accept the accusation of communist-domination made by the movement's accusers as evidence of such domination. Such incomplete logic has only served to further marginalize the historical relevance of the rank and file movement to the profession and dampen scholarly inquiry into that history. The historical record of the relationship of the movement to the Communist Party and the party's relative influence in the unions is far from complete, and that nascent history has been flawed by the lack of an incorporation of a comprehensive examination of the terms of inquiry regarding association, influence, and domination. Indeed, the continuing politics of anti-communism are still well represented within our profession's history of the movement, and until this condition is rectified, a comprehensive historical record of the rank and file will not be achieved. 


\section{Notes to Chapter 7}

1. Interview by author with "Sarah," February 12, 1982. "Sarah" requested anonymity in her interview. A rank and file activist and union official in the mid-west, Sarah was one of a handful of social workers sentenced to prison for her refusal to cooperate with anti-Communist investigations in the 1950s. Despite receiving support from some of her former colleagues, Sarah recalled that she was abandoned and shunned by most. Following her release from prison, Sarah left the field and later retired in Seattle, Washington.

2. Alexander, Organizing the professional social worker, p. 201.

3. Ibid., pp. 201-202.

4. “Opinion," Social Work Journal (October 1948), p. 139.

5. Leighninger, Social work: Search for identity, p. 193.

6. Ibid.

7. Herbert Northrup, "Collective bargaining by professional societies," Social Work Journal (October 1948), p. 168.

8. Quoted in Alexander, Organizing the professional social worker, p. 206.

9. Jacob Fisher, Security risk (Sarasota, FL: Piney Branch Press, 1986).

10. Ibid.

11. Meyer Schreiber, "Labeling a social worker a national security risk: A memoir," Social Work 40(5) (1995), p. 659.

12. Interview by author with Margaret Wheeler, September 19, 1979.

13. Beck, Contempt of Congress, p. 234.

14. Interview by author with Abram Flaxer, August 16, 1980.

15. Milton Tambor, "Unions," in Richard Edwards (Ed.), Encyclopedia of Social Work, 19th edition [CD-Rom Version] (Washington, D.C.: NASW Press, 1995), no page number. 
16. Ibid.

17. Ibid. 


\section{REFERENCE LIST}

\section{Books}

American Association of Social Workers. (1929). Social casework generic and specific: A report of the Milford Conference Studies in the Practice of Social Casework. New York: AASW.

Anderson, M. (1951). Women at work. Minneapolis: University of Minnesota Press.

Austin, A. (1949). The labor story. New York: Coward-McCann.

Axinn, J., \& Levin, H. (1997). Social welfare: A history of the American response to need. New York: Longman.

Babbie, E. (1989). The practice of social research (Fifth Edition). Belmont, CA: Wadsworth.

Bailey, R., \& Brake, M. (1976). Radical social work. New York: Random House. Barrett, E. L. (1951). The Tenney Committee: Legislative investigation of subversive activities in California. Ithaca, NY: Cornell University Press.

Barzun, J., \& Graff, H. F. (1985). The modern researcher. New York: Harcourt Brace Jovanovich.

Beck, C. (1959). Contempt of Congress: A study of prosecutions initiated by the Committee on Un-American Activities. New York: De Capo Press.

Belfrage, C. (1989). The American inquisition, 1945-1960. New York: Thunder's Mouth Press. 
Bernstein, I. (1966). The lean years: A history of the American worker, 1920-1933. Baltimore: Penguin Books.

Bernstein, I. (1970). Turbulent years: A history of the American worker, 19331941. Boston: Houghton Mifflin.

Bernstein, I. (1985). A caring society: The New Deal, the worker, and the Great Depression. Boston: Houghton Mifflin Company.

Bontecou, E. (1953). The federal loyalty-security program. Ithaca, NY: Cornell University Press.

Boyer, R. O., \& Morais, H. M. (1976). Labor's untold story. New York: United Electrical, Radio and Machine Workers of America.

Bremer, W. W. (1984). Depression winters: New York social workers and the New Deal. Philadelphia: Temple University Press.

Browder, E. (1933). What is the New Deal? New York: Workers Library.

Carr, R. K. (1952). The House Committee on Un-American Activities, 1945-1950. Ithaca, NY: Cornell University Press.

Carson, M. (1990). Settlement folk: Social thoughts and the American Settlement Movement 1885-1930. Chicago: The University of Chicago Press.

Caute, D. (1978). The great fear: The anti-Communist purge under Truman and Eisenhower. New York: Simon and Schuster.

Caute, D. (1988). The fellow-travelers: Intellectual friends of communism. New Haven, CT: Yale University Press. 
Chambers, C. A. (1963). Seedtime of reform. American social service and social action 1918-1933. Westport, CT: Greenwood Press.

Chambers, C. A. (1972). Paul U. Kellogg and the Survey. Minneapolis: University of Minnesota Press.

Chaney, G. (1968). A long journey. Chicago: Quadrangle Books.

Claudin, F. (1975). The communist movement: From Comintern to Cominform, Part One. New York: Monthly Review Press.

Claudin, F. (1975). The communist movement: From Comintern to Cominform, Part Two. New York: Monthly Review Press.

Corrigan, P., \& Leonard, P. (1978). Social work practice under capitalism: A Marxist approach. London: MacMillan Press.

Dennis, P. (1977). The autobiography of an American communist: A personal view of a political life, 1925-1975. Berkeley: Lawrence Hill.

Dilling, E. (1934). The red network. (Chicago: self published).

Dimitroff, G. (1938). The united front. New York: International Publishers.

Draper, T. (1957). The roots of American communism. New York: Viking Press.

Draper, T. (1960). American Communism and Soviet Russia. New York: Viking Press.

Drury, A. (1965). Three kids in a cart: A visit to Ike, and other diversions. (Garden City, NY: Doubleday \& Co.).

Dunway, D. K. \& Baum. B. K. (Eds.) (1984). Oral history: An interdisciplinary anthology. Nashville, TN: American Association for State and Local History. 
Ehrenreich, J. H. (1985). The altruistic imagination. Ithaca, NY: Comell University Press.

Feuer, L. S. (1969). Marx and the Intellectuals. Garden City, NY: Anchor Books. Fischer, D. H. (1970). Historian's fallacies: Towards a logic of historical thought. New York: Harper \& Row.

Fisher, J. (1936). The rank and file movement in social work. New York: New York School of Social Work.

Fisher, J. (1979). On vanishing ground: A memoir of the twenties. Fairfax, VA: Piney Branch Press.

Fisher, J. (1980). The response of social work to the Depression. Boston: G. K. Hall and Company.

Fisher, J. (1986). Security risk. Sarasota, FL: Piney Branch Press.

Folsom, F. (1991). Impatient armies of the poor. Niwot, CO: University Press of Colorado.

Foster, W. Z. (1947). American trade unionism: Principles, organization, strategy, tactics. New York: International Publishers.

Foster, W. Z. (1952). History of the Communist Party of the United States. New York: International Publishers.

Galbraith, J. K. (1955). The great crash, 1929. Boston: Houghton-Mifflin.

Galper, J. H. (1975). The politics of social services. Englewood Cliffs, NJ: PrenticeHall. 
Gellhorn, W. (Ed.). (1952). The states and subversion. Ithaca, NY: Cornell

University Press.

Ginger, A. F., \& Christiano, D. (Eds.) (1987). The cold war against labor.

Berkeley, CA: Meiklejohn Civil Liberties Institute.

Glazer, N. (1961). The social basis of American communism. New York:

Harcourt, Brace and World, Inc.

Goffman, E. (1959). The presentation of self in everyday life. Garden City, NY:

Doubleday.

Goodman, W. (1968). The committee: The extraordinary career of the House

Committee on Un-American Activities. New York: Farrar, Straus and Giroux.

Healey, D. R., \& Isserman, M. (1993). California red: A life in the American

Communist Party. Chicago: University of Illinois Press.

Hill, M. R. (1993). Archival strategies and techniques. Newbury Park, CA: Sage.

Hopkins, H. (1972). Spending to save. Seattle: University of Washington Press.

Howe, I., \& Coser, L. (1957). The American Communist Party. Boston: Beacon Press.

Institute of Marxism-Leninism. (1971). Outline history of the Communist International: Moscow, U.S.S.R.: Progress Publishers.

Isserman, M. (1982). Which side were you on? The American Communist Party during the Second World War. Middletown, CT: Wesleyan University Press.

Isserman, M. (1987). If I had a hammer...The death of the old left and the birth of the new left. New York: Basic Books. 
Jacobs, P. (1965). Is Curly Jewish? A political self-portrait. New York: Antheum. Jansson, B. S. (1997). The reluctant welfare state. American social welfare policies: Past, present, and future. New York: Brooks/Cole Publishing Company.

Jenkins, K. (1995). On what is history? From Carr and Elton to Rorty and White. New York: Routledge.

Jones, C. (1983). State social work and the working class. Boston: Routledge \& Kegan Paul.

Kampelman, M. (1957). The Communist Party vs. the C.I.O. New York: Praeger.

Karger, H. J. (Ed.) (1988). Social workers and labor unions. New York:

Greenwood Press.

Kaye, H. J. (1991). The powers of the past. Reflections on the crisis and promise of history. Minneapolis: University of Minnesota Press.

Kirschner, D. S. (1986). The paradox of professionalism. Reform and public service in urban America, 1900-1940. New York: Greenwood Press.

Klehr, H. (1984). The heyday of American communism. New York: Basic Books.

Klehr, H., Haynes, J. E., \& Anderson, K. M. (1998). The Soviet world of American communism. New Haven: Yale University Press.

Klehr, H., Haynes, J. E., \& Firsov, F. I. (1995). The secret world of American communism. New Haven: Yale University Press.

Lader, L. (1979). Power on the left. New York: W. W. Norton and Company. 
Lamont, C. (1968). The trial of Elizabeth Gurley Brown by the American Civil Liberties Union. New York: Horizon Press.

Leighninger, L. (1987). Social work: Search for identity. New York: Greenwood Press.

Levenstein, H. A. (1981). Communism, anti-communism, and the CIO. Westport, CT: The Greenwood Press.

Lubove, R. (1975). The professional altruist. The emergence of social work as a career 1880-1930. New York: Antheum.

Lorence, J. (1996). Organizing the unemployed. Albany: State University of New York Press.

Lurie, H. L. (1961). A heritage affirmed. The Jewish Federation movement in America. New York: The Jewish Publication Society of America.

Martin, R. R. (1987). Oral history in social work education: Chronicling the black experience. Journal of Social Work Education, 23(3), 5-10.

McCulloch, M. (1983). White collar workers in transition: The boom years, 19401970. Westport, CT: The Greenwood Press.

Meyer, F. (1961). The moulding of communists: The training of the communist cadre. New York: Harcourt, Brace and Co.

Mills, C. W. (1967). The sociological imagination. New York: Oxford University Press.

Naison, M. (1983). Communists in Harlem during the Depression. New York: Grove Press. 
National Conference of Charities and Corrections. (1918). Proceedings of the National Conference on Charities and Corrections. Chicago: University of Chicago Press.

National Conference of Social Work. (1931). Proceedings of the National Conference of Social Work, 1931. Chicago: University of Chicago Press. National Conference of Social Work. (1932). Proceedings of the National Conference of Social Work, 1932. Chicago: University of Chicago Press. National Conference of Social Work. (1935). Proceedings of the National Conference of Social Work, 1935. Chicago: University of Chicago Press. Neuman, W. L. (1994). Social research methods. Boston: Allyn and Bacon. Pells, R. H. (1973). Radical visions \& American dreams: Cultural and social thought in the Depression years. New York: Harper \& Row.

Piven, F. F., \& Cloward, R. A. (1977). Poor people's movements: Why they succeed, how they fail. New York: Pantheon Books.

Preis, A. (1972). Labor's giant step. Twenty years of the CIO. New York: Pathfinder Press.

Reid, P. N., \& Popple, P. R. (1992). The moral purposes of social work. Chicago: Nelson-Hall.

Reynolds, B. C. (1963). An uncharted journey. New York: The Citadel Press.

Reynolds, B. C. (1985). Learning and teaching in the practice of social work. Silverspring, MD: National Association of Social Workers. 
Reynolds, B. C. (1987). Social work and social living. Silverspring, MD: National Association of Social Workers.

Richmond, M. (1917). Social diagnosis. New York: Russell Sage Foundation.

Roberts, C. (1996). The logic of historical explanation. University Park, PA: The Pennsylvania State University Press.

Robinson, V. (1930). A changing psychology in social case work. Chapel Hill: University of North Carolina Press.

Rosswurm, S. (Ed.). (1992). The CIO's left-led unions. New Brunswick, NJ:

Rutgers University Press.

Rothman, G. C. (1985). Philanthropists, therapists and activists. Cambridge, MA:

Schenkman Publishing Co.

Saposs, D. J. (1959). Communism in American unions. New York: McGraw-Hill Book Company.

Schrecker, E. W. (1986). No ivory tower: McCarthyism and the universities. New York: Oxford University Press.

Schrecker, E. W. (1998). Many are the crimes: McCarthyism in America. New York: Little, Brown and Company.

Simon, B. L. (1994). The empowerment tradition in American social work: A history. New York: Columbia University Press.

Spano, R. (1982). The rank and file movement in social work. Washington, D.C.: University Press of America. 
Specht, H., \& Courtney, M. (1994). Unfaithful angels: How social work has abandoned its mission. New York: The Free Press.

Starobin, J. R. (1972). American communism in crisis, 1943-1957. Cambridge, MA: Harvard University Press.

Trattner, W. I. (1999). From poor law to welfare state. A history of social welfare in America. New York: The Free Press.

Trolander, J. A. (1975). Settlement houses and the Great Depression. Detroit: Wayne State University Press.

Walker, P. (Ed.). (1979). Between labor and capital: The professional managerial class. Boston: Sound End Press

Watkins, T. H. (1993). The Great Depression: America in the 1930s. New York: Little-Brown.

Wenocur, S., \& Reisch, M. (1989). From charity to enterprise: The development of American social work in a market economy. Chicago: University of Illinois Press.

Zieger, R. H. (1995). The CIO, 1935-1955. Chapel Hill, NC: University of North Carolina Press.

\section{Articles and Book Chapters}

AASW and AASWS. (1940). Social Work Today, 7(9), 26.

AASW and social defense. (1940). Social Work Today, 8(2), 26.

AASW drafts another program. (1937). Social Work Today, 4(7), 5-6.

AASW examines the Dawson case. (1935). Social Work Today, 2(4), 25-27. 
Abbott, E. (1936). Public welfare and politics. Proceedings of the National Conference of Social Work, 1936 (pp. 27-45). Chicago: University of Chicago Press.

Addams, J. (1895). The Settlement as a factor in the labor movement. In Residents of Hull House (Eds.). Hull House maps and papers. New York: Thomas Y. Crowell.

A. F. of L. - Mostly pro. (1936). Social Work Today, 3(6), 26.

Albright, W. (1936). Roosevelt's back to the land program. Social Work Today, 3(8), pp. 15-18.

Alexander, L. B., \& Speizman, M. D. (1979). The union movement in voluntary social work. In Social Welfare Forum, 1979 (pp. 179-187). New York: Columbia University Press.

Alexander, L. B., \& Lichtenberg, P. (1978). The "Case Work Notebook": An analysis of its content. Journal of Sociology and Social Welfare, 5(1), 55-66.

Allen, D. (1935). Our jobs need us! The New York stoppage. Social Work Today, $3(3), 5-7$.

Allen, D. (1937). C.I.O. for public agencies. Social Work Today, 5(1), 9-10.

An appeal for Spain. (1937). Social Work Today, 4(7), 4.

An open letter to William Hodson. (1934)., "Social Work Today, 1(3), 19. And again, relief crises. (1938). Social Work Today, 5(9), 29-31. 
Andrews, J., \& Reisch, M. (1997). The legacy of McCarthyism on social group work: An historical analysis. Journal of Sociology and Social Welfare, 24(3), 211-235.

Andrews, J., \& Reisch, M. (1997). Social work and anti-communism: An historical analysis of the McCarthy era. Journal of Progressive Human Services, 8(2), 2949.

Baker, J. H. (1937). A great second congress. Social Work Today, 5(3), 9-10.

Baldwin, R. (1924). The challenge to social work of the changing control in industry. In Proceedings of the National Conference of Social Work, 1924 (pp. 373-379). Chicago: University of Chicago Press.

Baldwin, R. (1935). Social workers and war: A comment. Social Work Today, 2(4), 28.

Bancroft, F. C. (1940). Social work and defense. Social Work Today, 8(1), 7-10. Barclay, G. (1940). Welfare, not warfare. Social Work Today, 8(1), 11.

Barnard, A. V. (1935). Insubordination in New Jersey. Social Work Today, 2(5), 27-28.

Bartlett, L. (1936). The attack on the Townsend Plan. Social Work Today, 3(8), pp. $11-12$.

Benjamin, H. (1940). After a decade of mass unemployment. The Communist, 19(3), 259-277.

Berman, H., \& Stocker, R. (1936). Collective bargaining in New York. Social Work Today, 3(9), 16-17. 
Billikopf, J., \& Glassberg, B. (1926). Trade unions and the family welfare agency. Proceedings of the National Conference of Social Work, 1926 (pp. 339-346). Chicago: University of Chicago Press.

Borders, K. (1933). Social workers and a new social order. Proceedings of the National Conference of Social Work, 1933 (pp. 590-607). Chicago: University of Chicago Press.

Boyer, M. (1935). A people's congress. Social Work Today, 2(4), 5-7.

Brandt, A. (1935). Why men fight. Social Work Today, 2(4), 28-29.

Breines, S. (1937). Uncle Sam clears a slum. Social Work Today, 4(6), 7-8.

Browder, E. (1935). Recent political developments and some problems of the United Front. The Communist, 14(7), 604-624.

California Strategy Committee, SCMWA-CIO. (1940). Professional values and county jails. Social Work Today, 7(9), 15, 30.

The case for the practitioners' movement. (1933). The Compass (October, 1933), 45.

Case record of new Spain. (1937). Social Work Today, 5(3), 21-22.

The case of Sidonia Dawson. (1935). The Survey, 71(1), 8-9.

Case work notebook. (1936). Social Work Today, 4(1), 23-24.

Case work notebook. (1937). Social Work Today, 4(8), 21-22.

Case work notebook. (1938). Social Work Today, 5(5), 21-22.

Case work notebook. (1940). Social Work Today, 7(4), 23-24.

Case work notebook. (1940). Social Work Today, 7(6), 23-24. 
Case work notebook. (1940). Social Work Today, 7(7), 23-24.

Chappel, W. I. (1937). Social workers and war. Social Work Today, 5(2), 11-12.

Chicago hoists the flag. (1938). Social Work Today, 5(4), 4.

Child Care Commission. (1937). Children of the new Spain. Social Work Today, $5(2), 9-11$.

Cohen, M. (1938). Protecting professional standards. Social Work Today, 5(6), $15-$ 16.

Collective bargaining in New York. (1935). Social Work Today 3(1), 5.

Comaner, A. (1937). The AASW thinks aloud. Social Work Today, 5(2), 16.

Conferences: 1934 style. (1934). Social Work Today, 1(6), p. 4.

Congress and social work. (1937). Social Work Today, 4(5), 3-5.

Coyle, D. C. (1934). Illusions regarding revolution. The Survey, 70(7), 211-214.

Coyle, G. (1937). Group work and social action. Social Work Today, 5(2), pp. 1315.

The crisis of the N.R.A. ( November 8, 1933). New Republic, p. 350.

A damning indictment. (1935). Social Work Today, 3(2), 5.

Deutsch, A. (1941). Let's face facts this time. Social Work Today, 9(1), 3-6.

Deutsch, A. (1944). American labor and social work. Science and Society, 8(4), 289-304.

Directory of rank and file organizations. (1935). Social Work Today, 2(3), 31.

Doliner, H. (1940). In answer to war hysteria. Social Work Today, 8(1), 12-13. 
Douglas, D. W. (1935). Unemployment insurance - for whom? Social Work Today, 2(4), 9-12, 34.

Draft convention resolutions. (1938). The Communist (April), 355.

Emmett, C. (1934). The unemployed propose action. Social Work Today, 1(1), 6-7.

Executive Committee of Association of Federation Workers of the Association of Federation Workers in New York. (1932). The history and activities of the Association of Federation Workers in New York. The Jewish Social Service Quarterly 8 (June), 181-183.

Feder, J. (1938). Youth's own agency. Social Work Today, 5(7), 19-20.

Finison, L. J. (1977). Radical professions in the Great Depression. An historical note: The InterProfessional Association. Radical History Review, 4(2-3), 133136.

Fisher, J. (1934). Social work and liberalism. Social Work Today, (1)2: 9-12.

Fisher, J. (1935). Meet the relief administration. Social Work Today 3(4), 8-9.

Fisher, J. (1935). Rank and file challenge. Social Work Today, 2(5), 5-8.

Fisher, J. (1936). The rank and file movement 1930-1936. Social Work Today, $3(5), 5-7$.

Fisher, J. (1937). Forward with the C.I.O. Social Work Today, 5(1), 8-10.

Fisher, J. (1938). One year of the CIO in social work. Social Work Today, 5(9), 2124.

Fisher, J. (1941). Running out on the needy. Social Work Today, 8(9), 17. 
Flaxer, A. (1938). The social worker as a servant of the people. Social Work Today, 5(9), 31.

For the children of Spain. (1937). The Survey, 73(6), p. 191.

Frey, J. (1936). Aliens on relief. Social Work Today, 3(8), 18.

Gavit, J. (1938). Through neighbors doorways. Survey Graphic (December), p.

611.

Gilpin, D. W. (1935). Fired for "inefficiency". Social Work Today, 3(2), 11-13.

A glossary for rank and filers M - P. (1936). Social Work Today, 3(4), 23-24.

A glossary for rank and filers P - S. (1936). Social Work Today, 3(6), 23-24.

Gordon, W. (1934). Protecting the social service employee. Social Work Today, $1(1), 9-11$.

Granger, L. B. (1937). Harlem comes of age. Social Work Today, 4(8), 9-12.

Granger, L. B. (1938). The urban colored population. Social Work Today 5(6),1012.

Hathway, M. (1937). The right to training. Social Work Today, 5(1), 11-12.

Haynes, J. E. (1975). The "rank and file movement" in private social work. Labor History, 16(1), 78-98.

Hedin, G. (1935). The Riback firing. Social Work Today, 2(4), 16-17.

Hedin, G. (1935). Spying, discrimination, dismissals. Social Work Today, 2(6), 1314.

Hodson, W. (1934). The President's position. The Survey, 70(6), 189. 
Hodson, W. (1929). The social worker and politics. In Proceedings of the National Conference of Social Work, 1929 (pp. 103-112). Chicago: University of Chicago Press.

Hodson, W. (1932). The effect of the Depression on professional standards. In Proceedings of the National Conference of Social Work, 1932 (pp. 535-536). Chicago: University of Chicago Press.

Hubert, J. H. (1937). Needs of Negro children. Social Work Today, 4(7), 13-15. Isserman, M. (1985). Three generations: Historians view American communism. Labor History, 26(Fall).

Jacobson, G. (1942). Defeat fascism. Social Work Today, 9(3), 32-34.

Kahn, D. C. (1935). Professional standards in social work. Compass (June), 1-2.

Kahn, D. C. (1940). Cleveland - Points East and West. Social Work Today, 7(4), $13-14$.

Kaplun, D., and de Schweinitz, K. (1938). Needed - In-service training. Social Work Today, 6(3), 9-10.

Kellogg, P. (1939). Between going to war - And doing nothing. Survey Graphic (March), 228.

Kenneally, J. J. (1973). Women and trade unions, 1870-1920: The quandary of the reformer. Labor History, 14(1), 42-55.

Kovarsky, M. (1935). AASW at Washington. Social Work Today, 2(5), 22-23.

Kyle, C. (1942). In the war to win. Social Work Today, 9(3), 29-31. 
Kyle, C., and Chakin, J. (1938). Spain's call and our answer. Social Work Today, $5(7), 13-14$.

Labor unity and the 1938 elections. (1938). Social Work Today, 5(9), 4.

Lane, R. (1935). Red squad on the coast. Social Work Today, 2(5), 26.

Lasswell, J. (1935). Shovels and guns. The CCC in action. Social Work Today, $2(5), 9-13,34$.

Lee, P. R. (1929). Social work: Cause and function. Proceedings of the National Conference of Social Work, 1929 (pp. 3-20). Chicago: University of Chicago Press.

Leighninger, L., \& Knickmeyer, R. (1976). The rank and file movement: The relevance of radical social work traditions to modern social work practice. Journal of Sociology and Social Welfare, 4(2), 168-177.

A letter to the social workers of America. (1935). Social Work Today 2(7), 4. Levy, J. H. (1934). New forms of organization among social workers. Proceedings of the National Conference of Social Work, 1934 (pp. 532-538). Chicago: University of Chicago Press.

Lewis, J. L. (1938). Welcome to the ranks of labor. Social Work Today, 5(4), 8. Lewis warns political parties about war. (1940). Social Work Today, 7(9), 27. Lindeman, E. (1934). The future of the professional. Social Work Today 1(3), 1418.

Linder, Leo. J. (1936). The new Workers Social Insurance Bill. Social Work Today, 3(6), 9-12. 
Logan, R. W. (1939). The Negro and the New Deal. Social Work Today, 6(9), 7-8.

Lowell, P. (1934). Social workers take counsel. Social Work Today, 1(1), 3-6.

Lowenstein, S. (1938). The test of American democracy. In Proceedings of the National Conference of Social Work, 1938 (Chicago: University of Chicago Press), p. 20.

Lurie, H. L. (1934). Wanted - $\$ 2,400,000,000$. Social Work Today, 1(1), 8-9.

Lurie, H. L. (1935). The dilemma of the social worker. Social Work Today, 3(1), $13-15$.

Lurie, H. L. (1936). Quitting the relief business. Social Work Today, 3(8), 5-8.

MacLeish, A. (1939). Liberalism and the anti-fascist front. Survey Graphic (May), $321-323$.

Malbin, V. (1940). Grand rapids comes to the conference. Social Work Today 7(9), $11-14$

Marcus, G. F. (1939). Sigmund Freud: An appreciation. Social Work Today, 7(2),

6.

Marcus, G. F. (1941). Changes in the theory of relief-giving. Social Work Today, $8(9), 6-9,29$.

McMillen, W. (1937). Trade unionism for social workers. Social Work Today, 4(7), 7-9.

Medical aid to Spain. (1937). Social Work Today, 4(8), 29.

Meeting social need: A peace program. (1940). Social Work Today, 7(4), 5-6.

Miller, L. (1935). Jim Crow in relief. Social Work Today, 2(6), 28. 
Milo, P. (1937). Doin' somethin' FOR Negroes. Social Work Today, 4(4), 13-14.

The month. (1938). Social Work Today, 5(8), 25-26.

The month. (1934). Social Work Today, 7(9), 27.

The most generous city in the world. (1934). Social Work Today 1(2), 12-14.

Mr. Roosevelt - so far. (June 28, 1933). The Nation, 711-712.

National Committee on Civil Rights in Social Work (1948). Civil rights in social work - A preliminary policy statement. Social Work Journal, 29(4), 150-152.

National Conference of Charities and Corrections. (1918). Proceedings of the National Conference of Charities and Corrections, 1918. Chicago: Russ and Hall, Co.

NCC at Montreal. (1935). Social Work Today, 2(7), 8.

Nedelsky, W., \& Johnson, M. (1937). Things grow in California. Social Work Today, 5(3), 11-12.

The New Deal is our deal. (1939). Social Work Today, 6(9), 38.

Next steps in national organization. (1935). Social Work Today, 2(7), 13-16.

Northrup, H. (1948). Collective bargaining for professional societies. Social Work Journal 29(4), 163-169.

Now that the election is over. (1936). Social Work Today, 4(3), 3-4.

O'Brien, F. S. (1968). The "Communist-dominated" unions in the United States since 1950. Labor History, 9(2), 184-209.

On the organizational front. (1937). Social Work Today, 4(9), 6-7.

Peace and democracy: Agenda. (1938). Social Work Today, 5(7), 4. 
The people's program in 1941. (1941). Social Work Today, 8(8), 3.

Philadelphia witch-hunt. (1942). Social Work Today, 9(3), 29.

Phillips, N. K., \& Lehman, H. H. (1985). Ideology and opportunity in social work during the New Deal years. Journal of Sociology and Social Welfare, 12: 251273.

A plea for understanding. (1936). Social Work Today, 3(9), 4.

A positive peace policy. (1939). Social Work Today, 6(8), 25.

Prosperity through scarcity: The status of the workers under the NRA. (1933). Common Sense (September, 1933), 8-10.

Rabinowtiz, C. (1938). The AASW drafts another program. Social Work Today, $4(7), 5-6$

Rabinowitz, C. (1940). Mr. President, we want peace. Social Work Today, 7(9), 78.

Rank and file. (1934). Social Work Today, 1(2), 23.

Rank and file. (1934). Social Work Today, 1(4), 20-21.

Rank and file. (1935). Social Work Today, 2(3), 26-28.

Rank and file. (1935). Social Work Today, 2(4), 1.

Red squad on the coast. (1935). Social Work Today 2(5), 26.

Reid, I. D. (1934). The Negro riddance act. Social Work Today, I(1), 13-14.

Reimer, M. (1935). The unemployed - Second class citizen. Social Work Today, 2(6), 16-18. 
Reynolds, B. C. (1930). The role of the psychiatric social worker in therapy. In ICMH (Eds.), Proceedings, First International Conference of Mental Hygiene, Vol. 1 (Washington, D.C.: International Conference of Mental Hygiene), pp. 4669.

Reynolds, B. C. (1935). Whom do social workers serve? Social Work Today, 2(6), $5-8$.

Reynolds, B. C. (1938). Re-thinking social casework. Social Work Today, 5(7), 5-

8.

Reynolds, B. C. (1938). Re-thinking social casework II. Social Work Today, 5(8), 5-7.

Reynolds, B. C. (1938). Re-thinking social casework III. Social Work Today, 5(9), $5-7$.

Reynolds, B. C. (1939). Social workers and the democratic process. Social Work Today, 7(1), 4 .

Reynolds, B. C. (1942). There will be new heights of devotion. Social Work Today, $9(4), 50$.

Roosevelt's program for recovery. (1938). Social Work Today, 5(8), 4.

Running out on the unemployed. (1937). Social Work Today, 4(9), 3-4.

Sann, P. (1938). Can we discard the WPA? Social Work Today, 5(4), 3-5.

Say 'social worker' to the census man. (1930), The Compass (February), 1.

Schreiber, M. S. (1995). Labeling a social worker a national security risk: A memoir. Social Work, 40(5), 656-660. 
SCMWA convention. (1940). Social Work Today, 8(1), 27.

Should social work employes use labor tactics? (1936). Social Work Today, 3(4), 5-

7.

Should social work employes use labor tactics? Three more opinions. (1936).

Social Work Today, 3(5), 18-19.

Sidonia Dawson and the AASW. (1935). The Survey, 71(2), 92-94.

Siegel, M. (1936). Worker and client join hands. Social Work Today, 3(4), 18.

Slater, M. (1935). Spying, discrimination, dismissals. Social Work Today, 2(6), 1314.

Social work conferences: 1934 style (1934). Social Work Today, 1(3), 3-7.

Social work in America. (1934). Social Work Today, I(1), 2.

Social work in the nation's service. Social Work Today, 9(3), 3-4.

Social work practices. (1934). Social Work Today, 1(7), 16-17.

Social work today. (1934). Social Service Review, 8(2), p. 372.

Social work today. (1934). The Survey, 70(4), p. 127.

Social workers and the presidential election. (1936). Social Work Today, 4(2), 5-7

Social work's answer. (1939). Social Work Today, 6(4), 23.

Social work's stake in the election. (1936). Social Work Today, 4(1), 4.

Springer, G. (1934). Rising to a new challenge. The Survey, 70(6), 179-180.

Springer, G. (1938). The fighting spirit in hard times. The Survey, 68(6), 260-272.

Springer, G., \& Baker, H. C. (1934). The national conference at work. The Survey, 71(6), 181-189. 
Springer, G., \& Baker, H. C. (1935). Social workers view their world. The Survey, 71(7), 195-206.

Springer, G., \& Close, K. (1940). Our defense must be from within. The Survey, 76(6), 187-196.

Stack, C. (1936). Youth demands a chance. Social Work Today, 3(8), 13.

Straussner, S. L. A., \& Phillips, N. K. (1988). The relationship between social work and labor unions: A history of strife and cooperation. Journal of Sociology and Social Welfare, 15(1), 105-118.

Survey. (November 15, 1929), pp. 195-196.

Swing to the A. F. of L. (1936). Social Work Today 3(7), 3-4.

Tambor, M. (1995). Unions. In Edwards, R. (Ed.), Encyclopedia of social work, 19th edition [CD-Rom version] (Washington, D.C.: NASW Press.

Trade union notes. (1939). Social Work Today, 6(4), 25.

Trade union notes. (1939). Social Work Today, 6(6), 25.

Trade union notes. (1939). Social Work Today, 6(8), 27.

Two conventions. (1935). Social Work Today, 2(5), 2.

van Kleeck, M. (1932). Social planning and social work. Proceedings of the National Conference of Social Work, 1932 (pp. 294-300). Chicago: University of Chicago Press.

van Kleeck, M. (1933). Observations on management in the Soviet Union. Taylor Society Bulletin (April), 31-36. 
van Kleeck, M. (1933). Prosperity through security: The status of the workers under the NRA. Common Sense (September), 8-10.

van Kleeck, M. (1933). Dictatorships and democracy. Soviet Russia Today (November), 6-8, 15.

van Kleeck, M. (1934). An open letter from Mary van Kleeck. Social Work Today, $1(1), 12$.

van Kleeck, M. (1934). The common goals of labor and social work. Proceedings of the National Conference of Social Work, 1934 (pp. 284-303). Chicago: University of Chicago Press.

van Kleeck, M. (1934). The effect of the N.R.A. on labor. Proceedings of the National Conference of Social Work, 1934 (pp. 428-436). Chicago: University of Chicago Press.

van Kleeck, M. (1934). Our illusions regarding government. Proceedings of the National Conference of Social Work, 1934 (pp. 473-485). Chicago: University of Chicago Press.

van Kleeck, M. (1935). Social work in the economic crisis. Proceedings of the National Conference of Social Work, 1935 (pp. 64-77). Chicago: University of Chicago Press.

van Kleeck, M. (1935). Sources of power for the social work program. Do we need a labor party? Social Work Today, 3(3), 8-11.

van Kleeck, M. (1940). Social work in the world crisis. Social Work Today, 7(6), 5-8. 
Van Waters, M. (1930). Philosophical trends in modern social work. Proceedings of the National Conference of Social Work, 1930 (pp. 3-19). Chicago:

University of Chicago Press.

Wagner, D. (1986). Collective mobility and fragmentation: A model of social work history. Journal of Sociology and Social Welfare, 13: 657-700.

The war and the New Deal. (1939). Social Work Today, 7(1), 5.

We support the president. (1937). Social Work Today, 4(7), 3.

What of national organization? The NCC redefines its position. (1936). Social Work Today, 3(5), 24-25.

Where are the jobs, Mr. Hopkins? (1937). Social Work Today, 5(1), 5-6.

Whose security? (1935). Social Work Today, 2(3), 4-5.

Willmer, M. (1935). Victory in Baltimore. Social Work Today, 3(2), 22-23.

Women in industry. (1918). The New Republic, 17 (October 26), p. 366.

\section{Newspapers, Newsletters and Pamphlets}

Daily Worker (1939, July 6), p. 4.

Keep American out of the imperialist war. (1939, September 19). The Daily Worker, p. 1.

McGowan brands Yorty committee as red baiters. (1940, March 23). Visalia TimesDelta, p. 1.

McKenzie, A., \& Doliner, H. (1937). The Negro worker and the ERB [Pamphlet]. New York: Association of Workers in Public Relief Agencies. 
State, County and Municipal Workers of America, California Division. (1940).

While you're not looking [Pamphlet]. San Francisco: SCMWA.

State, County and Municipal Workers of America, Local 204. (1940). Statement by Local \#204 of the State, County and Municipal Workers of America given to the Yorty Committee at the Vislaia hearings on March 21 and 22, 1940.

Uhl, K. (1939, October 3). Union worried by cleanup plans. Visalia Times-Delta, p. 1 .

Uhl, K. (1939, December 13). CIO dominating state relief office. Visalia TimesDelta, p. 3.

Uhl, K. (1940, March 23). Complaint is issued after Yorty committee concludes two-day hearing; Others in SRA facing prosecution. Visalia Times-Delta, p. 1. Union Voice (1953). Volume 9, \#6.

Yorty victims acquitted. (1940, December 1). People's World, p. 2.

\section{State and Federal Documents}

State of Califormia. Legislature Assembly. Joint Fact-finding Committee on UnAmerican Activities (1956). Un-American activities in California-Cumulative Index. Sacramento: California State Printing Office.

State of California. Legislature Assembly. Relief Investigating Committee. (1940). Report on subversive activities. Sacramento: California State Printing Office.

U.S. Congress. House of Representatives. Committee on Un-American Activities. (1944). Investigation of Un-American activities and propaganda. U.S.

Congress, $2^{\text {nd }}$ Session, March 29, 1944. 
U.S. Congress. House of Representatives. Committee on Un-American Activities. (1951). Guide to subversive organizations and publications (and appendix). $84^{\text {th }}$ Congress, $1^{\text {st }}$ Session. March.

U. S. Congress. House of Representatives. Committee on Un-American Activities. (1953). Investigation of communist activities in the California area-Part 5. $83^{\text {rd }}$ Congress, $1^{\text {st }}$ session.

U. S. Congress. House of Representatives. Committee on Un-American Activities. (1953). Communist political subversion. $83^{\text {rd }}$ Congress, $2^{\text {nd }}$ session.

U.S. Congress. House of Representatives. Committee on Un-American Activities. (1953-54). Investigation of communist activities in the Philadelphia area. Hearings. Parts 1-4. $83^{\text {rd }}$ Congress, $1^{\text {st }}$ and $2^{\text {nd }}$ Sessions.

U. S. Congress. House of Representatives. (1953). Investigation of communist activities in the New York City area - Part 1. $83^{\text {rd }}$ Congress, $1^{\text {st }}$ session.

U.S. Congress. House of Representatives. Committee on Un-American Activities. (1957). Communist Party activities in the professions. Hearings held in San Francisco, California. $84^{\text {th }}$ Congress, $1^{\text {st }}$ session.

U.S. Congress. House of Representatives. Committee on Un-American Activities. (1957). Investigation of communist activities in the New Haven, Conn. area Part 3, February 26-27, 1957. $85^{\text {th }}$ Session, $1^{\text {st }}$ session.

U.S. Congress. House of Representatives. Committee on Un-American Activities. (1957). Investigation of communist activities in the Seattle, Wa. area-Part 2. $84^{\text {th }}$ Congress, $1^{\text {st }}$ session. 
U.S. Congress. Senate. Senate Committee on Government Operations. (1957).

Congressional investigations of Communists and subversive activities -

Summary index $1918-1956.84^{\text {th }}$ Congress, December, 1957, \#148.

U.S. Congress. Senate. Subcommittee on Internal Security of the Committee on the Judiciary. (1952). Subversive control of the Distributive, Processing and Office Workers of America. Hearings. $82 \mathrm{~d}$ Congress, $1^{\text {st }}$ and $2^{\text {nd }}$ Session.

U.S. Congress. Senate. Subcommittee on Internal Security of the Committee on the Judiciary. (1952). Subversive control of the United Public Workers of America. Hearings. 82d Congress, $1^{\text {st }}$ Session.

\section{Union Documents}

Congress of Industrial Organizations (1949). Proceedings of the $11^{\text {th }}$ Constitutional Convention of the Congress of Industrial Organizations. Cleveland, Ohio.

Distributive, Processing and Office Workers of America (1950). Proceedings of the Founding Convention: Distributive, Processing and Office Workers of America. New York City, New York.

\section{Unpublished Materials}

Alexander, L. B. (1977). Organizing the professional social worker: The union movement in voluntary social work: 1930 - 1950. (Unpublished doctoral dissertation, Bryn Mawr College).

Freedberg, S. (1984). Bertha Capen Reynolds: A woman struggling in her times. (Unpublished doctoral dissertation, Columbia University). 
Moore, D. E. (1986). Mary van Kleeck: A biographical sketch and annotated bibliography of her writings. (Unpublished masters thesis, Florida Atlantic University).

Olson, T. L. (1972). Unfinished business: American social work in pursuit of reform, community, and world peace, 1939-1950. (Unpublished doctoral dissertation, University of Minnesota).

Prickett, J. R. (1975). Communists and the communist issue in the American labor movement, 1920-1950. (Unpublished doctoral dissertation, University of California, Los Angeles).

Schriver, J. M. (1984). Henry Lawrence Lurie, a rational radical: His contributions to the development of social work, 1930-1950. (Unpublished doctoral dissertation, University of Iowa).

Steelfeldt, W. J. (1951). United Public Workers of America v. Harry B. Mitchell:

The doctrine of political neutrality. (Unpublished doctoral dissertation, University of Chicago).

\section{Archival Materials}

Max Bogner Papers

Jacob Fisher Papers

Marion Hathway Papers
Social Welfare History Archives University of Minnesota Minneapolis, MN

Social Welfare History Archives University of Minnesota Minneapolis, MN

Social Welfare History Archives University of Minnesota Minneapolis, MN 
Paul Kellogg Papers

Harry L. Lurie Papers

Bertha C. Reynolds

Papers

Bertha C. Reynolds

Papers

Bertha Reynolds Club

Archives

\section{Correspondence}

Chauncey Alexander

Herbert Aptheker

Julia Barnes

Max Bogner

Abraham Flaxer

Jacob Fisher

Dorothy Healey

Jack Kamaiko

Barbara Klein

Margaret Levy
Social Welfare History Archives University of Minnesota

Minneapolis, $\mathrm{MN}$

Social Welfare History Archives University of Minnesota

Minneapolis, $\mathrm{MN}$

Sophia Smith Collection, Smith College

Northampton, MA

American Institute for Marxist Studies

New York, NY

Communist Party USA Headquarters

New York, NY

Communist Party USA Headquarters

New York, NY

August 26, 1980

July 28,1980

July 5,1980

August 12, 1980

August 12, 1980

January 1, 1980; March 30, 1980; July 18, 1980;

August 28, 1980; February 12, 1981

August 7, 1980

June 17,1980

August 2, 1980

September 25, 1979; October 2, 1979; August 9, 1980; 
September 5, 1980

Clara Rabinowitz

Mary Russak

Marie Talbot

Verne Weed

George Wolfe

Bronislaus Zukas

\section{Interviews}

Herbert Aptheker

Julia Barnes

Eleanor Cohen

Julia Davis

Abram Flaxer

Jacob Fisher

Gus Hall

Dorothy Healey

Irene Hobbs

Celia Katz

Barbara Klein

Rachel Levine

Margaret Levy
August 12, 1980; September 1, 1980

August 23, 1980

October 9, 1979

March 31, 1980; April 18, 1980; May 4, 1980

April 12, 1980; May 15, 1980; June 29, 1980

May 23, 1980; June 14, 1980; July 25, 1980; August 11, 1980; August 28, 1980

July 28,1980

January 14,1981

February 12, 1994

March 17, 1996

August 16, 1980

September 9, 1980; February 12, 1981

November 12, 1983

August 23, 1980; September 26, 1980

February 13, 1981

May 15, 1981

August 19, 1980

May 5, 1986

October 12, 1980; September 12,13, 1981 
“Max"

Leo Miller

George Morris

Clara Rabinowitz

Mary Russak

"Sarah"

Marie Talbot

Verne Weed

Margaret Wheeler

George Wolfe

Bronislaus Zukas
February 17, 1990

April 16, 1997

November 18,1980

November 24, 1980

December 13, 1980

February 2, 1982

December 4, 1979

July 21,1980

September 19, 1979

July 3,1980

September 28, 1980; October 14, 1980 


\section{Appendix: Historical Research Method}

For the purposes of this study, the author employed what has generally been termed the historical-comparative research method. ${ }^{1}$ Finding its roots in the work of Emile Durkheim, Max Weber, and Karl Marx, the historical-comparative method, while containing within its rubric a broad array of approaches and specific techniques, places analytic emphasis on the understanding of an historical period or event within both the overarching flow of history and the specific social and cultural context of the historic situation under study. In this fashion, historical-comparative research seeks to identify not only the objective facts of a historical period but to interpret the meaning of these facts within the cultural-historical context and their application for current social problems and discourse. ${ }^{2}$

Two primary strategies were used in the collection of data: archival and oral history technique. Both strategies share a common feature of reliance upon primary sources as the target of data collection and subsequent analysis. While both strategies share a search for original sources, these sources differ in form and content. The former relies upon written primary sources of information (e.g., letters, diaries, official documents), while the latter relies upon the spoken word (oral recollections and memories) of persons who participated in the period of history under study. ${ }^{3}$

While the uses and relative strengths and weaknesses of these and other strategies employed in this study are discussed in more detail below, it is important to make an observation on the shared implications of archival and oral history 
method within an historical-comparative approach. Both methods of data collection share a common strength of providing the researcher direct access to the past; that is, the researcher's interpretations of history are based on materials of the time under study and hold the strongest potential for classification and verification. ${ }^{4}$ As opposed to substantive reliance on secondary information sources, in which the researcher is faced with disentangling another author's interpretation of historical data, the researcher using primary data sources can base analyses and interpretations upon the actual words and records of the actors in the historical narrative. However, the strength of this direct connection with the past paradoxically reveals its weakness: the records of the past, be they written or oral, are at best fragmentary and limited by the context of their production. Primary sources reflect history in the making, not history as product. The use of primary data is bound by the intended or unintended distortions of their creators, the acts of their caretakers (be it archivists or the memory of the actor), and the physical and intellectual corrosives of time. ${ }^{5}$ Accordingly, the comparison and triangulation of multiple data sources took on heightened priority in this historical study.

\section{Use of Archives}

Generally speaking, archives refer to organized collections of written documents pertaining to particular individuals, organizations, social movements or other historical events. ${ }^{6}$ Such collections can be contained in formal archive facilities organized and maintained by universities, unions, governmental institutions, or other organizations and commonly consist of materials such as letters, 
diaries, minutes of meetings, unpublished manuscripts, internal organizational documents, and other forms of written records. Formal archives are usually available for use by the general public and researchers, although certain restrictions on the availability and use of documents may be imposed based on the physical condition of the documents or the nature of the subject (e.g., access to classified government documents or proprietary documents of businesses). A closely related source of materials includes documents in the personal possession of individuals (either the subject of inquiry or family members) and from whom permission must be sought for inspection and conditions for use arranged.

In developing an archival search strategy, the author compiled a master list of names of individuals, organizations and social movements relevant to the rank and file movement in order to identify selection of archives and facilitate the subsequent identification and review of other relevant collections. The development of this master list was accomplished through a standard literature review (e.g., periodical indexes, dissertation abstracts, biographical indexes). Sources derived from this master list were then used to cross-check with archive collections throughout the United States.

The author conducted an extensive literature review that encompassed published primary source materials, secondary source publications, "fugitive" (unpublished) materials, and personal correspondence with participants in the rank and file movement. These references were categorized and cross-referenced across four major categories: (1) references directly concerned with the rank and file 
movement; (2) references more generally pertaining to the historical development of the social work profession during the time under study; (3) references pertaining to the general labor movement of the time; and (4) references related to radical movements and organizations of the time (e.g., the Communist Party and the unemployed workers movement).

\section{Archival Techniques Employed}

Three primary strategies were employed in the archival research: chronology, networks and cohorts, and backstage perspectives and processes. ${ }^{7}$ The use of chronology refers to the organization of materials into a timeline based on dates and events identified through the initial literature review. In addition to providing a basic temporal record of events, chronological organization allowed the author to identify changing roles or patterns of behavior by individuals and organizations to compare these chronologies in order to identify points of convergence or divergence. Equally important, the development and review of a chronology allowed the author to more easily identify gaps in the timeline that required further investigation to complete the documentary record.

Archival materials were also used to identify social networks of individual actors, institutions and organizations involved in the rank and file movement. By tracing the origins and routes of formal and informal communications (e.g., letters, memos, reports, meeting attendance records) the author developed a relatively dense matrix of individual and group linkages, influential relationships, and patterns or 
individual and group participation and membership; all of which assisted the author in the construction and interpretation of the historical materal. ${ }^{8}$

The third major strategy employed involved the discovery and analysis of underlying backstage motives of historical actors (individuals or organizations) and the validity of their publicly expressed values, behaviors or beliefs. ${ }^{9}$ Based on Goffman's ${ }^{10}$ work on the differing nature of the private and public presentations of self (front stage vs. backstage), this strategy sought to identify points of divergence or convergence between these public and private motives and behaviors. This process of analysis involved the comparison of documents or materials prepared for

public consumption (e.g., reports, speeches, pamphlets) with documents intended by the actor to be private or limited in circulation (e.g., letters, diaries, notes) in order to ascertain the overt and covert motivations and intentions of organizations and individuals. ${ }^{.1}$

\section{Use of oral/written history methodology}

Oral history interviews with participants in the rank and file movement were another important source of data for the proposed study. It should be noted that a variant of the oral history interview, the use of correspondence and written interview schedules with subjects, is also germane to this study, and the general steps engaged in by the researcher to collect the data correspond with the oral history technique. Martin argues that oral history techniques are warranted or in fact desirable when several conditions face the researcher, including the lack of written documentary evidence, the need to supplement or verify existing documentary evidence, and the 
desire to capture participants' sense of the meaning of an historical event or era. ${ }^{12}$ In these senses, oral history interviews allow the researcher to directly communicate with participants of the event or subject of inquiry to confirm or disconfirm previously published records of "fact", to explore details of events not previously known or understood, and to incorporate the recollected motives, feelings, and beliefs of interviewees into their analysis. Given the incomplete nature of archival data, the use of these interviews, oral and written, were essential to this study.

The collection and incorporation of such data served to more fully complete the documentary record, and of equal import, exposed the author to the felt reality of the participants. Such exposures, be they through archival or oral history method, speak to the interpretive nature of historical research; that is, history is the product of both the documentary past and the personal interests, convictions, and assumptions of the researcher. ${ }^{13}$

Following the guidelines of Martin, the author used the following general steps in the collection of oral and written histories: ${ }^{14}$

1. Definition of the selected topics to be discussed with the interviewee(s).

2. Identification of the interview participants. This step involved the identification of and implementation of a sampling strategy to obtain interview subjects.

3. Interviewing/data collection.

4. Transcribing and editing taped interviews. Interviews were transcribed into written narratives, providing margin space for notes, annotations and comments in analysis. 
5. Analysis and interpretation of the data. This final step engaged the author in the coding, classification and verification of transcript narrative. The data collected were compared and evaluated against other documentary evidence and interpreted within the context of the emerging historical narrative.

In regard to the interview subjects, many were leaders of the national rank and file movement (including members of the National Coordinating Committee and major trade unions representing social workers). In addition, the author interviewed "rank and file" members engaged in local organizing and activity, as well as key members of the Communist Party who were closely affiliated with the organizational efforts of the movement.

A purposive sampling method was used in the identification of interview subjects and entailed two strategies. The first strategy involved the identification and location of specific key surviving authorities in the rank and file movement through a review of the literature and documentary evidence. The second strategy involved a snowball approach to identifying and locating participants. This approach to sampling required the author to identify initial interview subjects who in turn identified additional subjects for the author. ${ }^{15}$ While this sample cannot be said to be representative, it is important to note that the subjects contacted included a range of key union leaders and activists in various sections of the country.

\section{Analytic and interpretive issues of the methodological strategies}

Archival and oral/written interview method share a number of common strengths and weaknesses, particularly in relation to the validity and reliability of 
data obtained and the resulting interpretive issues/dilemmas inherent in historical research. Martin notes that within the context of oral history research, validity “...defines the degree of conformity between the reports of the event and the event itself, as recorded by other primary sources..." and that reliability refers to the extent to which collected information is consistent internally; that is, “...does it tell the same story about the same event on a number of different occasions?"16 In a similar discussion concerning archival research, Hill notes that researchers must pay close attention to the dynamics of "sedimentation" - the cumulative social and physical aspects by which documentation is included or excluded from collections, physically deteriorates or is destroyed over time, or is altered or fabricated. ${ }^{17}$

These issues of data reliability, validity and sedimentation pose numerous analytic and interpretive dilemmas for the researcher, as the ability to control the evidence is temporally beyond the reach of the researcher. In other words, the evidences of history, be they written documents or spoken reminiscences, are created and maintained by individuals (living or dead) other than the researcher, and the decisions of worth or unworthiness they place on the historical knowledge in their possession is solely theirs.

The practical implications of this iterative process presented a number of challenges to data reliability and validity and the subsequent historical interpretations of the author. Information, be it written or oral, can be subject to conscious or unconscious distortion or fabrication by their creators. Similarly, the social context and personal/ideological assumptions and biases of the author may have led to distorted 
interpretation of the data. ${ }^{18}$ To deal with these threats, the historical method of this research required a constant sifting and resifting of the evidentiary sands through the process of verification of data through triangulation with multiple primary sources, comparison of findings and interpretations with secondary analyses conducted by other researchers, and the search for and falsification of alternative hypotheses/interpretations. ${ }^{19}$

Such methodological and interpretive dilemmas are not unique to historical research and are in fact shared by the physical and other social sciences. The phenomena of history occur in the same universe as the other sciences, and, hence, are subject to the same material conditions. But unlike many other scientific fields of inquiry, the variables of history cannot be manipulated and replicated in a closed system; rather, the chain of causality is open for the interpreter to utilize the insights of study and reflection to argue the merits of a particular interpretation. And ultimately, it is the audience to which the interpretation of history is given that must judge its usefulness, logic and validity. 


\section{Notes to Appendix}

1. L. W. Neuman, Social research methods (Boston: Allyn and Bacon, 1994).

2. Ibid.

3. Michael Hill, Archival strategies and techniques (Newbury Park, CA: Sage, 1993); Ruth Martin, Oral history in social work (Newbury Park, CA: Sage, 1995).

4. J. Barzun and H. Graff. The modern researcher (New York: Harcourt Brace Jovanovich, 1985).

5. Ibid.

6. P. Brooks, Research in archives: The use of unpublished primary sources (Chicago: University of Chicago Press, 1969).

7. Ibid.; Michael Hill, Archival strategies and techniques (Newbury Park, CA: Sage, 1993).

8. Ibid

9. Ibid.

10. E. Goffman, The presentation of self in everyday life (Garden City, NY: Doubleday, 1959).

11. Michael Hill, Archival strategies and techniques.

12. Martin, Oral history in social work.

13. D. Dunway \& B. Baum (Eds.), Oral history: An interdisciplinary anthology (Nashville, TN: American Association for State and Local History, 1984); K. Jenkins, On what is history? From Carr and Elton to Rorty and White (New York: Routledge, 1995).

14. Martin, Oral history in social work.

15. Earl Babbie, The practice of social research (Fifth Edition) (Belmont, CA: Wadsworth, 1989). 
16. Martin, Oral history in social work, p. 51.

17. Hill, Archival strategies and techniques, p.8.

18. Harvey Kaye, The powers of the past (Minneapolis: University of Minnesota Press, 1991).

19. Barzun \& Graff, The modern researcher, David Fischer, Historian's fallacies: Towards a logic of historical thought (New York: Harper \& Row, 1970); Clayton Roberts, The logic of historical explanation (University Park, PA: The Pennsylvania State University Press, 1996). 